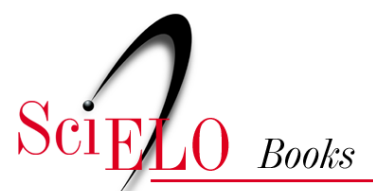

\title{
As ciências da vida de Canguilhem a Foucault
}

\author{
Vera Portocarrero
}

\section{SciELO Books / SciELO Livros / SciELO Libros}

PORTOCARRERO, V. As ciências da vida: de Canguilhem a Foucault [online]. Rio de Janeiro: Editora FIOCRUZ, 2009, 259 p. ISBN 978-85-7541-410-1. https://doi.org/10.7476/9788575414101.

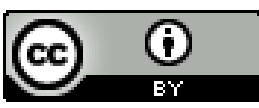

All the contents of this work, except where otherwise noted, is licensed under a Creative Commons Attribution 4.0 International license.

Todo o conteúdo deste trabalho, exceto quando houver ressalva, é publicado sob a licença Creative Commons Atribição 4.0. 


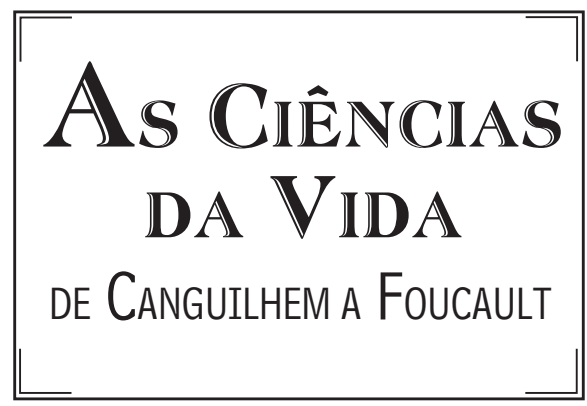




\section{FUNDAÇÃO OSWALDO CRUZ}

Presidente

Paulo Ernani Gadelha Vieira

Vice-Presidente de Ensino,

Informação e Comunicação

Maria do Carmo Leal

\section{EDITORA FIOCRUZ}

Diretora

Maria do Carmo Leal

Editor Executivo

João Carlos Canossa Mendes

Editores Científicos

Nísia Trindade Lima

Ricardo Ventura Santos

Conselho Editorial

Carlos E. A. Coimbra Jr.

Gerson Oliveira Penna

Gilberto Hochman

Lígia Vieira da Silva

Maria Cecília de Souza Minayo

Maria Elizabeth Lopes Moreira

Pedro Lagerblad de Oliveira

Ricardo Lourenço de Oliveira 


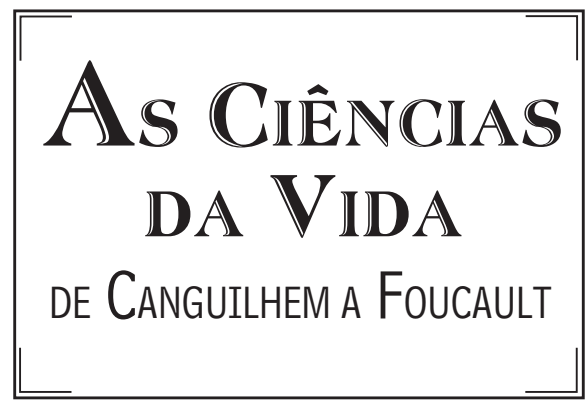

Vera Portocarrero

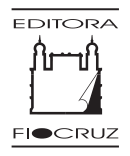


Copyright (C) 2009 da autora

Todos os direitos desta edição reservados à

FUNDAÇÃO OSWALDO CRUZ / EDITORA

ISBN: 978-85-7541-178-0

Capa, projeto gráfico

Carlota Rios

Fotos da capa

http://argoul.blog.lemonde.fr/files/2008/06/michel-foucault.1213343694.jpg

http://aulavirtual.files.wordpress.com/2007/04/canguilhem2.jpg

Revisão e copidesque

M. Cecilia G. B. Moreira

Normalização de referências

Clarissa Bravo

Catalogação na fonte

Centro de Informação Científica e Tecnológica

Biblioteca da Escola Nacional de Saúde Pública Sergio Arouca

P853c Portocarrero, Vera

As ciências da vida: de Canguilhem a Foucault. / Vera

Portocarrero. - Rio de Janeiro: Editora Fiocruz, 2009.

$260 \mathrm{p}$.

1. Filosofia. 2. Ciência. 3. Conhecimento. 4. Arqueologia. I. Título.

CDD - 22.ed. - 194

2009

EDITORA FIOCRUZ

Av. Brasil, 4036 - Térreo - sala 112 - Manguinhos

21040-361 - Rio de Janeiro - RJ

Tels: (21) 3882-9039 e 3882-9041

Telefax: (21) 3882-9006

e-mail: editora@fiocruz.br

http://www.fiocruz.br/editora 


\section{Sumário}

APRESENTAC̣Ão

PARTE I - FILOSOFIA, HISTÓRIA E CIÊNCIAS DA VIDA

1. Formas históricas de problematização 33

2. Conceitos e forças: objeto da história das ciências segundo Canguilhem e Latour $\quad 39$

3. Método em Salomont-Bayet, Jacob e Latour 51

PARTE II - VITALISMO, EPISTEMOLOGIA E ARQUEOLOGIA

4. Formas de valoração do vitalismo 77

5. Pasteur e a microbiologia 83

6. Vitalismo e constituição da biologia segundo Jacob, $\begin{array}{ll}\text { Canguilhem e Foucault } & 105\end{array}$

7. Filosofia, ciência e vida no pensamento de Canguilhem 127

PARTE III - VIDA, ARQUEOLOGIA E GENEALOGIA

8. Formas de investigação da vida no pensamento de Foucault 141

9. Descartes e a experiência da ordem na arqueologia 163

10. Representação e constituição do objeto na arqueologia 179

11. Ordem biológica, poder disciplinar e normalização 195

Dos ENSAIOS SOBRE EPISTEMOlogia, ARQUEOLOGIA E GENEALOGIA 221

ApÊNDICES

1. Vida, genealogia da ética e estética da existência 227

2. Governamentalidade e cuidado de si 237

REFERÊNCIAS 253 



\section{Apresentação}

Por detrás de toda a lógica e da autonomia aparente dos seus movimentos há valorações, ou, para me exprimir mais claramente, exigências fisiológicas para a manutenção de um determinado tipo de vida. Afirmar, por exemplo, que o determinado tem mais valor que o indeterminado, a aparência menos valor que a 'verdade': tais valorações, apesar da importância reguladora que têm para nós, não podem ir além de valorações de primeiro plano, uma espécie de niaiserie, útil talvez para conservação de seres tal como nós. (grifos do autor)

Nietzsche (1978)

Os ensaios aqui reunidos têm como ponto de partida uma preocupação com as ciências da vida. Poderiam ser uma história destas ciências. Mas as próprias noções de ciência e de vida tiveram de ser colocadas em questão. Não se pretende, aqui, definir uma verdade ontológica essencial da vida, nem a verdadeira lógica da ciência, mas a historicidade das ciências da vida. Trata-se, antes, de analisar formas de problematizá-las em nossa sociedade.

Durante todo o século XX, cada vez mais, a preocupação com as ciências da vida se manifesta em discursos que refletem sobre a vida e as ciências, cons- 
tituindo estratégias tanto de crítica ao processo de produção das biociências e da tecnologia que as integram como de reflexão sobre as questões filosóficas envolvidas. Pode-se mesmo afirmar que estas ciências, com a exigência de novas elaborações dos conceitos de norma, vida, morte e informação, ocupam lugar central nos debates científicos, sociais, principalmente, de bioética e de filosofia das ciências e da natureza, atribuindo-lhes uma relevância renovada.

A partir do final do século XVIII, interrogar os seres vivos e o homem envolve o conceito de vida e de ciência, cuja historicidade pode ser reconstruída através de uma história filosófica das ciências. É nesta perspectiva que a epistemologia de Georges Canguilhem bem como a arqueologia e a genealogia de Michel Foucault analisam questões cujo interesse está longe de ser esgotado. Trata-se, no primeiro caso, de questões epistemológicas que buscam a racionalidade da vida e da ciência, através de uma história crítica de conceitos; no segundo, de questões arqueológicas e genealógicas em busca de um pensamento crítico da ciência e da filosofia, através de uma história dos saberes e dos poderes que tenta constituir-se em resistência ao pensamento antropológico da modernidade, pensamento centrado no conceito moderno de homem.

Ao estudar, detalhada e rigorosamente, a constituição histórica das medicinas clássica e moderna, da história natural e da biologia, das filosofias clássica e moderna, a epistemologia e a arqueologia constituem formas de problematização que contribuem para identificar importantes fatores para a realização de um diagnóstico da atualidade. Sem dúvida, ao atuarem em dois níveis de análise, complementam-se mutuamente. A epistemologia analisa a construção da verdade realizada pelas ciências da vida em movimento, apontando rupturas, explicitando a atualidade desta construção e tornando-a compativel com o pensamento filosófico. A arqueologia dirige-se a outro nível de análise, voltando-se para a ordem interna e geral do saber, a fim de estabelecer relações entre as ciências biomédicas (medicina, biologia, fisiologia, anatomopatologia) e as outras ciências empíricas (economia política e filologia), a filosofia e a cultura. Já a genealogia relaciona biologia e política, saber e poder, numa crítica à medicalização e à normalização efetuadas em nossa sociedade.

Este é o tema central que integra a série de pesquisas que desenvolvi nos últimos anos, através do estudo de diferentes abordagens filosóficas e históricas na área biomédica. Esta série se desdobra em ensaios que partem de uma visão de conjunto da problematização da história das ciências da vida. O ensaio é privilegiado por mostrar a forma mais ativa para um pensamento que está sem- 
pre em movimento, o que é uma necessidade, se não de toda pesquisa, desta, sem dúvida, pelos objetos de que trata e pelos domínios em que se situa.

Estas pesquisas são exercícios de uma filosofia comprometida com a mudança e devem ser concebidas na perspectiva foucaultiana de uma produção sempre provisória e inacabada. Pois, a filosofia questiona aquilo que, em seu próprio pensamento, pode ser mudado através do exercício com outros saberes, através do ensaio. $\mathrm{O}$ ensaio consiste numa prova modificadora de si fazendo com que o pensamento não seja uma apresentação simplificadora e unificadora, nem um comentário que supõe resto ou excesso de significado.

Nesta atividade de comentário, que procura transformar um discurso condensado, antigo e como que silencioso a si mesmo, em um outro mais loquaz, ao mesmo tempo mais arcaico e mais contemporâneo, oculta-se uma estranha atitude a respeito da linguagem: comentar é, por definição, admitir um excesso do significado (...). Não seria possível fazer uma análise do discurso que escapasse à fatalidade do comentário, sem supor resto ou excesso no que foi dito, mas apenas o fato de seu aparecimento histórico? (...) Apareceria, então, a história sistemática dos discursos. (Foucault, 1977: XV)

Neste sentido, a filosofia não deve consistir em legitimar aquilo que se aprende com a ciência, nem em ditar, do exterior, leis aos saberes produzidos, como fazem diversas vertentes da história e da filosofia da ciência ao se basearem em princípios racionais considerados superiores. A filosofia, como explicita Foucault, consiste em questionar os saberes através da história de sua constituição, articulando-os com as práticas, para compreender as condições de possibilidade de sua existência, sem buscar uma teleologia, um sentido: “A história não tem 'sentido'; o que não quer dizer que seja absurda ou incoerente. Ao contrário, é inteligível e deve poder ser analisada em seus menores detalhes, mas segundo a inteligibilidade das lutas, das estratégias, das táticas” (Foucault, 1982: 5).

Traçam-se, aqui, questões interligadas, inicialmente apresentadas através de um estudo horizontal, numa perspectiva quase fragmentária, aparentemente eclética. São alguns aspectos de metodologia em análise histórica ligados à natureza de seu objeto e de seus objetivos. Constituem diferentes pontos de vista de uma mesma forma de problematização; tangenciam-se pela noção de historicidade do conceito de vida e de ciência e pelas análises de seu caráter de descontinuidade, o que lhes confere uma certa unidade. Os ensaios tornam-se verticais, a seguir, aprofundando, em torno da epistemologia, da arqueologia 
e da genealogia, questões específicas a estas formas de pensar. Cada ensaio apresenta seu fio condutor.

O primeiro ponto abordado é o conceito de vida em Pasteur, com o estudo da formação da noção de micróbio, através da constituição de uma rede de conceitos que relaciona objetos e métodos provenientes das técnicas de microscópio e de diversas ciências como a biologia, a química, a física, a cristalografia, a ótica. A leitura da obra completa de Pasteur (1922) permite observar que o conceito de vida como "ato vital", como algo que não pode advir do não-vivo, é uma questão fundamental para a forma de interrogar o organismo, em escala microscópica. ${ }^{1}$

$\mathrm{O}$ estudo do conceito de vida em Pasteur, preliminar à pesquisa da introdução do modelo microbiano em medicina no Brasil, inicialmente objetivada, terminou por conduzir à investigação do conceito de vida: 1) na história epistemológica da hereditariedade de François Jacob (1983); 2) nos estudos de Bruno Latour (1984) sobre a revolução pastoriana, que a trata em termos de relações de forças (denominando a revolução realizada por Pasteur de pastoriana, para diferenciá-la de pasteuriana, que diria respeito apenas às técnicas de pasteurização); 3) na história de Claire Salomont-Bayet (1986); e 4) nas obras completas de Georges Canguilhem e de Michel Foucault, principalmente. Assim, foi preciso pesquisar a mudança operada nos últimos quatro séculos na maneira de considerar a vida e o homem, quando se tornam objetos de ciência, conforme explicitado em Lógica da Vida (Jacob, 1983). Foi preciso, ainda, pesquisar a noção de vida, em seu sentido biológico, estendendo-a à idéia de vida humana, social e moral.

Foi a própria delimitação do objeto e do problema enfocados - as formas de problematização do conceito de vida, das noções de ciência e de saber, bem como suas relações com o poder e sua historicidade - que conduziu a metodologia deste estudo. Sem dúvida, o tema tratado aponta a importância da epistemologia de Canguilhem e, sobretudo, das teses arqueológicas e genealógicas de Foucault sobre a constituição das ciências biomédicas na modernidade, não só no nível de seus métodos de análise filosófica constituída em bases históricas, que são originais, mas também no nível de seus conteúdos temáticos.

Nesta perspectiva, o conjunto das pesquisas observou os seguintes procedimentos: 1) isolar os conceitos de vida, de ciência empírica, de medicina e filosofia modernas e analisar sua historiografia traçada nas obras dos referidos pensadores; 2) comparar, em seguida, os conteúdos destes conceitos e

1 Analiso esta questão na Revista da Sociedade Brasileira de História da Ciência (Portocarrero, 1991). 
de sua historiografia com suas concepções em diversas perspectivas relevantes no campo da filosofia e da história das ciências biomédicas, tais como: a) a da epistemologia de Canguilhem; b) a da história de François Jacob; c) a da arqueologia de Foucault, levando em consideração suas críticas às histórias das idéias - como as de Radl (1988), Lain Entralgo (1954, 1986), Littré (1878, 1889) e Déchambre (1889), emblemáticas destas últimas nos séculos XIX e XX; 3) comparar o nível arqueológico de análise com o da genealogia em Foucault e com o da epistemologia de Canguilhem, explicitando o método de cada um, seus diferentes preceitos metodológicos; 4) apresentar breve análise da genealogia elaborada no pensamento tardio de Foucault, a partir de um estudo das três formas de abordagem da vida em sua obra: a) como objeto de saber, b) como objeto de poder, c) como obra de arte. Uma vez que esta última afastase do tema das ciências da vida aqui objetivado, acrescentei dois pequenos apêndices abordando a genealogia da ética, a estética da existência, o cuidado de si e a governamentalidade.

As contribuições teóricas e metodológicas que mais marcaram esta investigação são provenientes da arqueologia de Foucault, na perspectiva da busca das condições da existência efetiva do saber considerado verdadeiro, e da epistemologia de Canguilhem, na perspectiva da análise conceitual, histórica e descontínua, porém sem considerar seu questionamento do valor de verdade dos saberes da vida.

Não se deve, portanto, confundir a preocupação histórica desta série de ensaios com aquela das histórias das idéias, criticadas na epistemologia, na arqueologia e na genealogia. ${ }^{2}$ As histórias das idéias elaboram narrativas dos fatos, idéias, debates e influências que explicam o progresso científico como um desenvolvimento linear da verdade científica, operado pela medicina e pela biologia, caracterizando, através de uma história factual, o abandono dos erros cometidos pela atitude predominantemente teórica, sistemática e especulativa das idéias de Hipócrates em medicina ou pelo aristotelismo em biologia. As análises arqueológicas e epistemológicas não são factuais; são conceituais e fundam-se na afirmação do caráter de historicidade dos saberes e das ciências, cujo tempo apresenta descontinuidades, visto que a constituição de um saber ou de uma ciência apresenta rupturas que são mudanças abruptas no desen-

2 Estes ensaios não se inserem na linha metodológica e teórica das epistemologias anglosaxônicas, nem dos social studies of science, tampouco das discussões sobre as dicotomias verdade ou erro, ciência ou tecnologia, ciência ou sociedade, ciência ou poder, teoria ou experimentação; menos ainda na linha das histórias das idéias - factuais, positivistas, lineares - ou das mentalidades ou do espírito de uma época. 
volvimento da ciência. As continuidades e descontinuidades do processo de produção da verdade científica, de acordo com a epistemologia, evidenciam que o erro tem uma positividade, porque a ciência não alcançaria seus objetivos se não conseguisse representar a sucessão de impasses, tentativas e retomadas, suas continuidades e descontinuidades.

No nível arqueológico, a descontinuidade é considerada como o fato de que em alguns anos, às vezes, uma cultura deixa de pensar como havia feito até então, e se põe a pensar uma outra coisa e de outra maneira; ou, ainda, como diria Foucault, como aquilo que se abre sem dúvida sobre uma erosão do fora, sobre este espaço que está, para o pensamento, do outro lado, mas onde, contudo, não deixou de pensar desde a origem. Tais mudanças devem-se a uma abertura do saber, que, no limite, Foucault explica através das relações do pensamento com a cultura. ${ }^{3}$ É pela análise das descontinuidades traçadas no nível arqueológico que se compreende como cada positividade, cada saber considerado positivo, se modificou; é através da alteração dos seres empíricos que povoam as positividades e do deslocamento das positividades umas em relação às outras - por exemplo, a relação entre a biologia, as ciências da linguagem e a economia - que ele mostra que, no século XIX, o espaço geral do saber não é mais o das identidades e diferenças, o da caracterização universal da taxinomia geral e da mathesis universalis clássicas.

Se as descontinuidades são, para Foucault, indispensáveis para definir os limites temporais do saber de uma época e, nela, o aparecimento de novas formas de empiricidades e de saberes, são as continuidades entre os diferentes saberes de uma determinada época que delimitam seu espaço geral; são as relações de diferentes ciências entre si e com a filosofia, a literatura, até mesmo a pintura, que permitem explicitar a configuração geral do saber numa episteme. ${ }^{4}$

3 Roberto Machado (2000) mostra, com razão, que Foucault chega a esta idéia de descontinuidade não só operando deslocamentos metodológicos em relação à epistemologia, mas também privilegiando a filosofia de Nietzsche, que denuncia e rejeita a supervalorização do espírito científico e do homem na modernidade. A arqueologia deve-se, em grande parte, ao interesse por Nietzsche e à sua problemática filosófica, bem diferente daquela dos epistemólogos a respeito da ciência, da verdade, da razão ou da modernidade.

4 A noção de episteme é cunhada por Foucault para indicar que há uma ordem interna constitutiva do saber de uma época. Podemos compreendê-la como o solo onde se enraízam os saberes com uma historicidade própria. A episteme significa a existência de um princípio de ordenação histórica dos saberes que independe e é anterior à ordenação dos discursos segundo critérios de cientificidade. Ela é a ordem específica do saber, sua configuração, a disposição que o saber assume em determinada época e que lhe confere uma positividade. A episteme tem um caráter de globalidade e de rede de necessidades - cada época caracteriza-se por uma única episteme que delimita o conjunto das formas necessárias do saber. 
É importante notar que, para Foucault, saber é uma categoria metodológica, um recurso instrumental que significa o nível do discurso e das formulações teóricas próprios do conhecimento científico ou com pretensão à cientificidade. Mesmo quando não legitimado como ciência, o saber possui uma positividade e obedece a regras de aparecimento, organização e transformação que podem ser descritas. A noção de saber aparece mais claramente em Les Mots et les Choses: une archéologie des sciences humaines, ${ }^{5}$ publicado em 1966, e só vai se explicitar de um modo mais sistemático em L'Archéologie du Savoir, ${ }^{6}$ publicado em 1969, justamente quando Foucault parece estar tentando precisar conceitos metodológicos em resposta às objeções que lhe foram feitas em relação às análises arqueológicas. De qualquer modo, a noção de saber permite apontar os limites da arqueologia e a introdução do projeto genealógico ao qual Foucault (1972, 1977) irá se dedicar em seguida. Até então, o nível arqueológico se apresenta como ligado à experiência e à percepção. ${ }^{?}$

Em Arqueologia do Saber, Foucault explicita o preceito metodológico de que a história arqueológica funda-se numa análise do discurso, considerado como um conjunto de enunciados que têm seus princípios de regularidade em uma mesma formação discursiva. Trata-se de um conjunto finito, de um grupo limitado, circunscrito, de uma seqüência finita de signos verbais que foram efetivamente formulados. $\mathrm{O}$ que interessa à arqueologia não são discursos possíveis, discursos para os quais se estabelecem princípios de verdade ou de validade a serem realizados; ela estuda os discursos reais que foram efetivamente pronunciados e que se apresentam com uma materialidade. A intenção desta história é ganhar o nível da prática, ao elucidar o surgimento dos saberes que correspondem ao aparecimento de um novo regime no discurso, apontado através das descontinuidades, das rupturas.

Pareceu-me que em certas formas de saber empírico, como a biologia, a economia política, a psiquiatria, a medicina etc., o ritmo das transformações não obedecia aos esquemas suaves e continuístas de desenvolvimento que normalmente se admite (sic) (...) Não são simplesmente novas descobertas; é um novo 'regime' no discurso e no saber. (Foucault, 1982: 3)

5 A partir daqui As Palavras e as Coisas (Foucault, 2002a).

6 A partir daqui Arqueologia do Saber (Foucault, 1969).

7 Como, por exemplo, a experiência e percepção da loucura, conforme analisada em História da Loucura (Foucault, 1972), e percepção da doença fundada na relação entre o olhar e a linguagem, conforme analisada em Nascimento da Ćlinica (Foucault, 1977). 
A novidade da arqueologia, então, é considerar os discursos não como teorias, ou abstrações, mas como regularidades que constituem práticas discursivas. Pois, há "saberes que são independentes das ciências", "mas não há saber sem uma prática discursiva definida; e toda prática discursiva pode se definir pelo saber que ela forma" (Foucault, 1969: 238). ${ }^{8}$ Para haver saber, basta a existência de uma prática discursiva. A prática discursiva é isolada pela arqueologia através da articulação entre os discursos - documentos filosóficos, científicos, literários etc. - e acontecimentos de outra ordem - técnica, social, econômica ou política - que formam séries temporais correspondentes. À exceção das análises desenvolvidas em As Palavras e as Coisas (2002a), toda a obra de Foucault é atravessada pela articulação do nível do discurso com o nível das práticas sociais, políticas e econômicas, num esquema de correspondência entre várias séries temporais.

É evidente a complexidade da noção de descontinuidades históricas diacrônicas (incompatibilidades e mutações em épocas diferentes) e continuidades históricas sincrônicas (compatibilidades e coerências numa mesma época). ${ }^{9}$ Esta noção de descontinuidades e continuidades substitui os preceitos da atualidade e da recorrência, propostos pela epistemologia de Bachelard, Koyré e Canguilhem, pelos da contemporaneidade e da positividade. Tal noção se deve ao deslocamento, operado por Foucault, em relação à epistemologia, da ciência para o saber. Este deslocamento conduz à indagação da possibilidade de que a noção de saber possa ser considerada em termos de uma complementaridade entre a epistemologia e a arqueologia na análise das ciências da vida. Teria sido tal complementaridade tornada possível devido a uma abertura da própria epistemologia ao dirigir sua investigação aos momentos de agitação e desordem no conhecimento científico?

A arqueologia se preocupa com a positividade dos saberes, ou seja, com as condições de sua existência, suas próprias regras de constituição e transformação para delimitar a singularidade de cada saber. Positividade no sentido do saber efetivo, que só pode ser submetido ao critério da história, e não ao da cientificidade ou da racionalidade, como poderia ser feito no nível epistemológico: "Mas se, do ponto de vista da racionalidade dos conhecimentos, podemos, realmente, falar em pré-história; para as positividades, só podemos falar em história" (Foucault, 2002a: 302).

\footnotetext{
8 As traduções de todas as citações desta obra são minhas.

9 Os conceitos metodológicos da arqueologia, como descontinuidade entre epistemes e a priori históricos, ocasionam inúmeras críticas a Foucault, positivas e negativas, como as de: Canguilhem (1967), Lebrun (1999), Han (1998), Dreyfus e Rabinow (1995), entre outras.
} 
Os ensaios aqui apresentados desenvolveram-se com base em análises conceituais no sentido conferido por Canguilhem, porém, como em Foucault, sem a preocupação da epistemologia francesa com o caráter de racionalidade e cientificidade. Seu objetivo não é discutir o estatuto da verdade das ciências da vida, mas sim especificar o que há de singular em nosso presente, diferenciar as particularidades de nossos saberes sobre a vida, de modo a fornecer subsídios para uma reflexão crítica das articulações estabelecidas entre os saberes e as práticas científicas e tecnológicas hoje produzidas. Para isto é importante investigar análises críticas cujo método relaciona o saber do presente com o de outras épocas, através de um recuo histórico até a formação dos conceitos operatórios que fazem funcionar o pensamento filosófico e científico na região das ciências da vida na modernidade. É nesta perspectiva que se privilegia aqui o estudo de determinadas formas filosóficas e históricas de problematizar a vida.

Para esta pesquisa, foram realizadas análises críticas dos seguintes textos: 1) obras de filosofia e de história das ciências da vida, de meados e final do século XX, com diferentes abordagens; 2) obras do século XIX, como as de Pasteur, Déchambre, Littré; 3) a obra completa de Canguilhem, em particular: Estudos de História e de Filosofia das Ciências (1970a), O Conhecimento da Vida (1965), Da Ciência e da Contra-Ciência (1971), Ideologia e Racionalidade nas Ciências da Vida (1977) e Vida (1973); 4) comentários de Paul Rabinow (1995) e de François Dagognet (1997) sobre a obra de Canguilhem; 5) a obra completa de Foucault, em particular: História da Loucura na Idade Clássica (1972), O Nascimento da Clínica: uma arqueologia do olhar (1977), e As Palauras e as Coisas, Arqueologia do Saber (1969), Ordem do Discurso (1971), Vigiar e Punir (1987), História da Sexualidade 1: a vontade de saber (2001a), História da Sexualidade 2: o uso dos prazeres (1984a), História da Sexualidade 3: o cuidado de si (1984b), Dits et Écrits, com ênfase nos volumes I (1994a), II (1994b) e IV (1994d), cursos proferidos no Collège de France (2002b, 2004, 2008a, 2008b, 2009).

Além destas, foi fundamental o estudo de: 1) análises de comentadores e críticos da obra de Foucault, particularmente de sua arqueologia, como Canguilhem (1967, 1970b, 1989, 1994a, 1994b), Roberto Machado (1979, 1981, 2000, 2000a, 2006), Gérard Lebrun (1985, 1999), Béatrice Han (1998), Gilles Deleuze (1963, 1966, 1981, 1988, 1994), Hubert Dreyfus (1995, 1999), Paul Rabinow (1995), John Rajchman (1987, 2000), dentre vários outros; 2) textos filosóficos considerados na arqueologia foucaultiana, na epistemologia de Canguilhem e na história de Jacob como marcos históricos - de Descartes, 
Regras para a Direção do Espírito (1999), e de Kant, Antropologia do Ponto de Vista Pragmático, ${ }^{10}$ Critique de la Raison Pure ${ }^{11}$ e Princípios Metafísicos da Ciência da Natureza (1990); 3) textos de seus comentadores, como Vuillemin (1955, 1960), Beck (1970), Alquié (1969), Derrida (1964, 1994), Beyssade (1972).

Os primeiros aspectos observados em relação à epistemologia foram a noção de que a filosofia das ciências possui uma dimensão histórica, seu caráter de reflexão sobre a produção de conhecimentos científicos, bem como a relevância conferida ao papel do erro imanente à produção da verdades cada vez mais depuradas. Já em relação à arqueologia, enfocou-se o privilégio da dimensão histórica das ciências no nível das condições de possibilidade da existência dos saberes. Neste nível, a história também se delimita pela problemática da racionalidade como saber, porém segue princípios diferentes dos da epistemologia ao se afastar do problema da recorrência - procedimento judicativo com relação à verdade instaurada pela ciência.

Enquanto a história epistemológica se caracteriza pela normatividade e pela recorrência - julga a verdade instaurada pela ciência -, a história arqueológica abandona os procedimentos judicativos, penetrando no nível do saber, onde há sempre uma positividade. A história arqueológica pesquisa as condições de existência dos saberes sobre o homem, com os quais as ciências da vida relacionam-se diretamente ao investigarem a vida do homem e manifestarem sua finitude que se impõe através da morte e da doença, tomando os saberes como discursos independentes das ciências, embora não se confundam com o senso comum. Para o arqueólogo, a análise deve buscar uma profundidade capaz de explicar a originalidade de uma região de saber, mostrando a articulação do nível do discurso com o das práticas. Já Canguilhem, que, ao se referir ao conceito, aponta a importância desta relação com a prática, como em Estudos de História e de Filosofia das Ciências (1970), raramente desenvolve em suas análises articulações do conceito fora do âmbito da ciência e da filosofia. ${ }^{12}$

$\mathrm{Na}$ arqueologia, tal articulação não se dá no sentido causal, pois não tenta explicar de que maneira as práticas políticas e econômicas determinam o fundamento da consciência dos homens e passam assim influenciar seus discursos. O que a arqueologia mostra é como e a que título as práticas políticas

${ }_{10}$ Foi utilizada a tradução Antropologie du Point de Vue Pragmatique (Kant, 1971).

${ }^{11}$ A partir daqui Crítica da Razão Pura (Kant, 1971).

12 Por exemplo, em "Novas reflexões referentes ao normal e ao patológico (1963-1966)", Canguilhem (2002) oferece uma destas raras articulações. 
e sociais, por exemplo, se constituem como condição de emergência, inserção e funcionamento dos discursos, como condições externas de possibilidade de seu aparecimento. Partindo da análise arqueológica das condições de possibilidade do surgimento e transformação dos saberes, Foucault chega à análise histórica das condições políticas de possibilidade dos discursos, à genealogia. Esta é a maneira pela qual chega ao estudo da vida do indivíduo com a noção de poder disciplinar e normalizador, como em Vigiar e Punir, e ao estudo da vida das populações com a noção de biopoder, como na História da Sexualidade 1: a vontade de saber.

O objeto dos ensaios aqui reunidos - as formas de problematização da vida e das ciências da vida no século XX - é constituído pelos conceitos de vida e de objeto empírico na perspectiva da epistemologia de Ganguilhem e sua relação com a perspectiva da arqueologia de Foucault; pelas noções de história e de historicidade das ciências da vida: sua constituição, as condições de possibilidade de sua existência e suas transformações ao longo do século passado; pela sua historiografia; e pelas relações estabelecidas na arqueologia entre as ciências da vida e a filosofia moderna. Relevam-se idéias desenvolvidas, sobretudo, em O Nascimento da Clinica e em As Palavras e as Coisas. Basicamente, a idéia, também explicitada por Jacob, de que o pensamento científico e filosófico contemporâneo tem sua origem na modernidade, no final do século XVIII e início do século XIX; e a idéia de uma descontuidade histórica entre a época clássica e a época moderna, a medicina clássica e a moderna, a história natural e a biologia, o pensamento da ordem e o da historicidade, entre a análise cartesiana e a crítica kantiana, entre a noção de representação e a de vida, entre poder na época clássica e poder disciplinar e biopoder.

Em As Palavras e as Coisas, a noção de vida constitui uma das condições de possibilidade do aparecimento da biologia no início do século XIX. A aparente, ou quase, continuidade entre as idéias e os temas da história natural e da biologia é considerada um efeito de superfície do nível arqueológico, através do qual Foucault desenvolve suas pesquisas dos anos 60. Do ponto de vista da arqueologia e da epistemologia, a descontinuidade entre o estudo dos seres vivos e o da vida corresponde a uma mutação profunda e maciça no sistema de conhecimento envolvendo o espaço geral do saber. Enquanto a história natural insere-se em um domínio de empiricidade, que pode ser ordenado e descrito em termos de formas visíveis e de espaço através do quadro classificatório, a biologia é coetânea do estabelecimento de um domínio de empiricidade que pode ser estabelecido e descrito de acordo com uma historicidade. 
Tal mudança deve-se à reordenação epistemológica ocorrida na passagem do século XVIII para o século XIX; pois o aparecimento de saberes empíricos como a biologia, bem como a possibilidade de um pensamento crítico transcendental, a partir de Kant, correspondem ao desaparecimento de um tipo de positividade, a do saber clássico, definido, pela arqueologia do saber, como análise das riquezas, dos seres vivos e das palavras. No século XIX, abandona-se o privilégio da análise da estrutura visível e ideal dos seres, e o conhecimento torna-se empírico, não tem mais as idéias como objeto. O objeto do saber empírico, então, é uma coisa concreta, mas que independe de sua visibilidade. É preciso penetrar no interior dos corpos para conhecê-los. Tal deslocamento assinala descontinuidades epistemológicas e arqueológicas, onde aparentes continuidades temáticas costumam ser apontadas.

A biologia ordenará os órgãos a partir de uma coerência entre sua própria historicidade e sua organização interna. O objeto empírico será pesquisado como mecanismo e funcionamento que apresentam um modo específico de existência, com suas próprias leis. As coisas formam um volume que lhe é próprio, definindo um espaço interno exterior à representação.

Cuvier ${ }^{13}$ (1769-1832) submete a disposição do órgão à soberania das funções, que, ao contrário das infinitas formas visíveis, reduzem-se à respiração, digestão, circulação e locomoção. As analogias estabelecidas pela função se desdobram, aproximando as distintas organizações numa série temporal. A função é invisível e será definida não pela forma perceptível, mas em termos dos efeitos produzidos pelos órgãos; ela vai permitir relacionar entre si conjuntos de elementos desprovidos de identidade visível. Aquilo que, para o olhar clássico - de superfície - eram simples diferenças justapostas às identidades deve então ser pensado a partir de uma homogeneidade funcional.

De acordo com a epistemologia e com a arqueologia, esta descontinuidade no âmbito da ciência corresponde ao novo tipo de filosofia inaugurada com a 'revolução copernicana'. Corresponde, ainda, ao deslocamento da questão filosófica que se dirige então para o problema da possibilidade de conhecer

${ }^{13}$ Cuvier é considerado o fundador da anatomia comparada. Para Foucault, Canguilhem e Jacob, é, sobretudo, o marco do surgimento da biologia moderna. Encontram-se no Vocabulário de Foucault algumas justificativas que sintetizam tal posição no pensamento de Foucault: "Foucault recorre à obra de Cuvier para descrever o nascimento da biologia e o modo de ser da vida na episteme moderna. (...) Cuvier liberou a subordinação dos caracteres de sua função taxonômica, para fazê-la entrar, para além de toda classificação eventual, nos diferentes planos de organização dos seres viventes (...). O espaço dos seres viventes gira em torno a essa noção [de organização] e a tudo o que havia podido aparecer, até agora, através da quadrícula da história natural (gênero, espécies, indivíduos, estruturas, órgãos), tudo o que se oferecia ao olhar ganha, a partir de agora, um novo modo de ser" (Castro, 2009: 96). 
a priori os objetos, a partir de uma submissão necessária do objeto ao sujeito; tal não se dá numa metafísica da representação e do ser, que caracteriza a filosofia clássica de Descartes, mas de uma analítica da finitude. Segundo Foucault, foi daí que nasceram os novos humanismos, as facilidades de uma antropologia, não a ciência, mas a reflexão geral da modernidade sobre o homem, que é, a seu ver, semi-positiva, semi-filosófica. A hipótese foucaultiana é que o saber não conseguiu escapar dessa disposição até nossos dias.

O desenvolvimento desta pesquisa conduziu à necessidade de analisar alguns aspectos teóricos bastante relevantes e que constituíram dificuldades nestes estudos. Em primeiro lugar, para delimitar um quadro das formas de problematização da vida e das ciências biomédicas e definir um critério para esta delimitação. $\mathrm{O}$ critério adotado foi o das pesquisas históricas que privilegiam a descontinuidade. Em segundo lugar, para estudar a idéia de uma incompatibilidade dos conteúdos da história natural e da medicina clássica (os seres vivos e a doença considerados como entidades abstratas, ideais) com os conteúdos da biologia e da medicina moderna, a vida empírica, concreta e a doença no corpo concreto do indivíduo. Foi necessário, ainda, precisar não só o papel de Kant como marco da ruptura da época clássica com a modernidade, ao estabelecer a distinção dos níveis de conhecimento transcendental e empírico, como também a constituição coetânea do conceito de vida como objeto empírico das ciências biomédicas - somente na modernidade. ${ }^{14}$

Foi necessário, também, analisar a história do surgimento do conceito de vida, na medicina e na biologia, sua historiografia, comparando a arqueologia de Foucault com a epistemologia de Canguilhem e mostrando os inúmeros pontos de coincidência e suas diferenças não só metodológicas, mas, principalmente, aquelas que dizem respeito aos diferentes valores atribuídos ao vitalismo por Foucault e por Canguilhem; pois há um problema de historiografia: a afirmação rejeitada por François Dagognet (1970) de que é Cuvier e não Lamarck $^{15}$ (1744-1829) o marco da biologia moderna, devido à relação de suas obras com a de Darwin, como afirmam Foucault (2002a) e Jacob (1983).

Mostrou-se muito importante, então, a partir da tese de Dagognet (1997) e do comentário elucidativo de Paul Rabinow (1994), a análise da consistência epistemológica da idéia de uma ciência da vida nas últimas décadas do século XX e da conseqüente consistência do vitalismo filosófico de Canguilhem, pautado

\footnotetext{
${ }_{14}$ Tais idéias foram elaboradas por Canguilhem (1966, 1967), Jacob (1983) e Foucault (1972, 1966).

${ }^{15}$ Cf. Lamarck, J. B. Philosophie Zoologique. Paris: Dentu, 1809.
} 
por uma história conceitual do conhecimento científico até o século passado. Tal idéia contribuiu para avançar a comparação do conceito de vida em Foucault e Canguilhem e explicitar, com mais rigor, suas diferenças a respeito do papel do vitalismo na constituição das ciências da vida.

Por último, buscou-se explicitar uma consistência do pensamento de Foucault, apesar das severas críticas que lhe foram dirigidas por Béatrice Han (1998) e outros estudiosos quanto a suas análises históricas e seus princípios de metodologia. Para tanto, foi preciso estudar a idéia de Foucault de que a forma dos conhecimentos científico e filosófico da época clássica pertence a um mesmo nível de saber, o da representação, e é incompatível com a forma do conhecimento das ciências empíricas (como as biomédicas) e da filosofia, na modernidade, que pertencem a diferentes níveis de saber, o nível dos conhecimentos empíricos e o nível transcendental.

$\mathrm{Na}$ trajetória desta pesquisa ficou muito claro o caráter polêmico da noção de representação, da historiografia das ciências da vida e da relação do conceito arqueológico de vida com o genealógico. Se os problemas daí decorrentes não foram exatamente solucionados, e nem sempre o foram, é que, sem dúvida, suscitam questões de porte que precisariam ser aprofundadas numa outra ocasião. $\mathrm{O}$ primeiro dentre tais problemas - o da representação - refere-se ao inusitado de ser ela considerada como uma disposição geral a que a cultura ocidental se vê submetida na época clássica, a episteme clássica, apesar de Foucault ter deixado clara sua função como forma geral do conhecimento filosófico e científico nessa época.

É interessante notar que Gérard Lebrun (1999) aborda este problema afirmando que, ao cotejar as análises de Foucault com a Krisis (Husserl, 1976), o caráter polêmico do conceito de representação se manifesta. Lebrun ressalta a crítica de Foucault à fenomenologia, bem como à análise da mathesis feita por Husserl na Krisis. Ao se dirigir aos numerosos saberes não matematizados da época clássica, Foucault rejeita a caracterização dos saberes dessa época como racionalismo e sua identificação com a matematização, com Galileu. Ele redefine a época clássica através de seu princípio fundamental de ordenação e de representação. Lebrun (1999: 34) afirma:

Em resumo, 1) a análise que Foucault faz da mathesis, segundo a linha cartesiana de Regulae, desloca o centro de gravidade do saber clássico; o que é universalmente garantido é o ordenável, não o calculável; 2) supondo que o ideal galileano seja, com efeito, aquele que Husserl descreve, é o campo da representação que explica sua irrupção, e não a 
imaginação de Galileu nem a circunstância de que este havia herdado um a priori geométrico já consolidado.

Trata-se, segundo Lebrun, nos dois casos - Husserl e Foucault -, de descrever o pensamento clássico em toda sua ingenuidade. Porém, explica, no caso de Foucault, trata-se, também, sobretudo de respeitar o caráter específico deste pensamento, sua positividade.

O segundo problema quanto ao caráter polêmico da noção de representação, da historiografia das ciências da vida e da relação do conceito arqueológico de vida com o genealógico diz respeito ao caráter polêmico da historiografia das ciências da vida na época moderna: suas cronologias, continuidades e descontinuidades entre Cuvier e Darwin, ou entre Lamarck e Darwin. As idéias da não preexistência de conceitos evolucionistas na época clássica, da não existência do conceito de vida antes do final do século XVIII, portanto, de uma história em que desaparece toda perspectiva de progresso e cujo tempo não é linear, tornam patente que a noção de descontinuidade histórica é muito mais complicada do que pode parecer a quem não se debruça sobre um trabalho documental de história das ciências.

Para Foucault, este problema, que é metodológico, diz respeito à impossibilidade de dar o mesmo estatuto e de fazer funcionarem da mesma maneira, no campo da história, resistências que podem ser do nível do conceito e resistências arqueológicas situadas no nível das formações discursivas. Mas, a historiografia elaborada por Foucault envolve muitas críticas, defesas e contestações, como as de: Dagognet (Foucault, 1994a: 27-66), Canguilhem (Foucault, 1994a: 27-66), Piveteau (Foucault, 1994a: 27-66), Grmeck (Foucault, 1994a: 27-66), dentre outros.

Em si mesma, a historiografia poderia não ser, exatamente, um grande problema. Porém, torna-se central à medida que enfocamos as complexas relações que, na modernidade, se estabelecem entre os conceitos de representação, de vida, e de homem, sua constituição como objeto empírico e sua separação do nível transcendental, as condições de possibilidade da reflexão filosófica e científica, bem como o pensamento literário; enfim, seus pressupostos filosóficos e metodológicos que abalam, profundamente, as histórias das ciências e da filosofia que nos são mais familiares.

O outro problema em discussão é o da passagem da arqueologia para a genealogia. $O$ trabalho de explicitação da noção de vida na obra de Foucault permite ver, primeiramente, que esta noção se coloca, em seu pensamento, 
em três momentos e de três maneiras diferentes. Nos anos 60, com Nascimento da Clinica e As Palavras e as Coisas, nos anos 70, a partir de Vigiar e Punir e de História da Sexualidade 1: a vontade de saber, e, em seguida, em História da Sexualidade 2: o uso dos prazeres e História da Sexualidade 3: o cuidado de si, nas inúmeras conferências e entrevistas, bem como nos cursos proferidos nos últimos anos de sua vida - esta última abordagem foi, aqui, apenas esboçada por não ser de interesse direto das questões a que se propõe este livro.

Sem dúvida, há uma descontinuidade entre o conceito arqueológico de vida e o genealógico, pois a arqueologia do saber busca o nível profundo das condições de possibilidade da existência dos saberes - das ciências, da filosofia, da literatura e da pintura. Na série de estudos arqueológicos encontramos análises meticulosas da constituição dos saberes científicos, realizadas através de um trabalho paciente de história das ciências. Ainda que sempre remetidas ao nível arqueológico e à dimensão de efeitos de superfície deste nível mais profundo, durante a década de 1960, as ciências se impõem como um ponto de passagem obrigatório para Foucault. ${ }^{16}$ Porém, a partir de Vigiar e Punir, isto já não acontece mais; o seu objetivo, então, é a constituição dos saberes no nível que os remete à dimensão de sua imanência com as relações de forças. É importante salientar as críticas de Béatrice Han, das quais discordo em alguns pontos, ao discutir a passagem da arqueologia à genealogia, seus conceitos mais fundamentais, buscando no projeto de Foucault o caráter de unidade e de sistema, a partir do qual aponta falhas em seu pensamento.

Nesta minha investigação, surgiu, também, o problema do caráter polêmico da relação da arqueologia com o pensamento filosófico do século XX. Apesar de não aparecerem explicitamente em meus textos, há alguns pontos particularmente interessantes sobre esta questão e que só puderam ser analisados após a publicação de Dits et Écrits, em 1994. Cito, aqui, apenas três pontos que chamam a atenção e que, de certa forma, tiveram que ser deixados de lado.

Em primeiro lugar, ao se referir ao trabalho meticuloso e profundo de história da astronomia realizado por Koyré (2001), publicado em 1957, Foucault (1994a: 170) afirma que ele "toma as idéias só neste momento de sua turbulência onde o verdadeiro e o falso ainda não estão separados; o que é contado é um trabalho indissociável, abaixo das divisões, feitas em seguida

${ }^{16}$ Justamente nesse período em que a literatura tem uma função positiva de contestação do humanismo das ciências do homem e das filosofias modernas, conforme afirma Machado (2000), é que Foucault (1994a: 157) realmente pesquisa as ciências, a ponto de afirmar mais tarde, em 1971, quando suas investigações já haviam se dirigido à questão do poder, que "pensava, no fundo, estar fazendo história das ciências". 
pela história”. A apologia deste nível abaixo das divisões vai de encontro com o que o arqueólogo definiu como a possibilidade de outro método de história que consiste numa certa maneira de considerar menos o conteúdo da ciência do que sua própria existência. Trata-se de uma certa maneira de interrogar os fatos num nível mais profundo, anterior, que permite ver que, numa cultura como a do Ocidente, a prática científica tem uma emergência, comporta uma existência e um desenvolvimento e segue um certo número de linhas de transformação, independentemente - até certo ponto - de seu conteúdo. Pois, para a arqueologia, a história das ciências não obedece à lei geral do progresso da razão - não é a razão a detentora das leis de sua história - porque há, abaixo daquilo que a ciência conhece, alguma coisa que ela não conhece, e seu devir, seus episódios, seus acidentes, obedecem a um certo número de leis e determinações de um domínio autônomo em relação à ciência - a episteme.

Em segundo lugar, a afirmação de Foucault de que Cassirer é neokantiano, atribuindo a este termo não o sentido de movimento ou escola filosófica, mas o da impossibilidade de ultrapassar o corte estabelecido por Kant, e de que, "neste sentido, nós somos todos neokantianos", devido à "injunção repetida sem cessar de reavivar este corte - ao mesmo tempo para encontrar sua necessidade e para tomar-lhe toda medida" (Foucault, 1994a: 546). Foucault remete o neokantismo ao dilema do pensamento moderno que ainda nos domina, mas que já sentimos vacilar sob os pés. O dilema seria o do pensamento oscilando entre o ser grego - do trágico, da poesia, da manhã do ser, do antigo - e o ser alfklärer - da enciclopédia, da língua bem feita, do meio-dia da representação, do clássico.

Em terceiro lugar, de fato, a relação da arqueologia com a filosofia moderna mostra-se muitas vezes obscura, principalmente no que tange a Kant, Heidegger, Husserl, Merleau-Ponty, Althusser, e à fenomenologia, ao positivismo, ao criticismo, ao existencialismo, ao estruturalismo e ao pragmatismo. Diversos comentários foram desenvolvidos a este respeito. Sabe-se muito bem com que insistência Foucault se esquiva do rótulo de filósofo para se posicionar contra o pensamento dialético e humanista da filosofia moderna. É notória sua necessidade exacerbada de declarar-se não estruturalista e seu esforço para explicar e justificar sua diferença.

$\mathrm{Na}$ época das investigações arqueológicas, tal esforço é freqüente e prolongado. Um exemplo: em debate sobre a situação de Cuvier na história da biologia (Foucault, 1994a), realizado por ocasião das Jornadas Cuvier, em 1969, Foucault ressalta o fato de assistirmos ao surgimento dos temas da morte, da 
sexualidade e da história como noções maiores e autônomas no pensamento do século XIX. Este fato parece ser a sanção filosófica da transformação produzida no campo das ciências da vida. À noção de morte, a filosofia teria reagido no sentido forte do termo, no sentido nietzschiano, como ele enfatiza, com o tema da normalidade do afrontamento da vida e da morte, sendo a morte considerada como aquilo que dá sentido à vida e a transforma em destino. À noção de sexualidade, a filosofia teria reagido relacionando-a com o amor, o tempo e a descendência. À noção de história e de descontinuidade a ela ligada, teria reagido com o tema da unidade de sentido, unidade fundamental de uma consciência livre, através de idéia de uma certa forma de dialética. "E o problema de toda filosofia nos séculos XIX e XX foi o de retomar as noções que acabavam de aparecer assim" (Foucault, 1994a: 65).

Por último, deste modo, Foucault (1994a: 65) enfatiza sua rejeição à filosofia humanista:

Chamo filosofia humanista toda filosofia que pretende que a morte é o sentido último e final da vida. Filosofia humanista, toda filosofia que pensa que a sexualidade foi feita para amar e proliferar. Filosofia humanista, toda filosofia que crê que a história está ligada à continuidade da consciência. (grifos do autor)

As considerações apresentadas são relevantes para uma introdução à pesquisa desenvolvida nos ensaios reunidos neste livro sobre as ciências da vida, que se divide em três partes. Na primeira parte, são discutidas diversas abordagens históricas das ciências biomédicas que constituem um conjunto conceitual operatório para a o projeto de pesquisa das formas de problematização da vida e das ciências da vida aqui proposto. Na segunda parte, o objetivo é isolar o conceito de vida no momento da constituição histórica das ciências da vida (biologia, fisiologia, medicina moderna), conforme Foucault, Canguilhem e Jacob estabelecem, a partir das seguintes questões: Como é possível que ao papel do vitalismo, na constituição da biologia, sejam atribuídos valores tão diferentes, como erro, como conceito operatório ou como efeito de superfície do nível arqueológico? As ciências da vida são possíveis? Qual a relação do vitalismo com a microbiologia do século XIX? Qual a relação entre os diferentes resultados das historiografias (conceitos relevantes, datações, marcos teóricos) e as diferenças metodológicas. Minha hipótese é que a história das ciências da vida realizada pela epistemologia francesa e pela arqueologia se complementam, embora apresentem posições diferentes com relação ao vitalismo, pois convergem quanto ao conceito de vida e sua historicidade. Apesar 
de contrariarem, igualmente, as cronologias que nos são mais familiares em história das ciências biomédicas, dirigem-se a níveis diferentes de questionamento e realizam diferentes análises filosóficas relevantes.

Os objetivos da terceira parte deste livro são vários. Em primeiro lugar, estabelecer relações entre a filosofia e as ciências da vida, na modernidade, através do estudo do conceito de vida na história filosófica das ciências realizada na arqueologia de Foucault, particularmente centralizada em Nascimento da Clínica e As Palavras e as Coisas. Em segundo lugar, analisar a noção de representação e a constituição do objeto na modernidade, no nível arqueológico, através das relações entre esta noção e a noção de vida como objeto empírico, concreto, independente da representação, bem como através do estudo da descrição e da crítica arqueológicas do espaço do saber na época moderna, onde há continuidade entre as ciências da vida, as ciências do homem e a filosofia que se constitui com um caráter antropológico. Aqui, a hipótese é que, apesar das severas críticas feitas a categorias metodológicas da arqueologia como representação, episteme, a priori histórico, entre outras, do ponto de vista da filosofia das ciências, estas categorias constituem valiosos instrumentos para a determinação arqueológica das condições de possibilidade da constituição do saber moderno. Neste sentido, as análises de Foucault sobre o surgimento do conceito de vida são claras quanto à descontinuidade que instaura nossa modernidade. Esta última parte do livro tem a finalidade de traçar os limites da noção arqueológica de vida em relação à pesquisa genealógica, a partir da questão da ordem como modalidade de conhecimento, estendida, no nível da prática, às formas de poder disciplinar, comparando-o com a normalização em nossa sociedade. Objetiva, ainda, fazer um recorte da investigação foucaultiana da noção de vida ao longo de sua obra, explicitando suas três diferentes formas de abordagem, com ênfase nas duas primeiras - a da arqueologia e a da genealogia do poder.

Em suma, os ensaios desta investigação agrupam-se em torno de três problemas principais que constituem as três partes deste livro: 1) o problema da história das ciências da vida, das questões que fundamentam as metodologias em filosofia e história das ciências biomédicas, de modo a discutir alguns aspectos bastante polêmicos das noções de ciência, de vida, de objeto, de verdade e de história das ciências; 2 ) o problema da concepção vitalista de vida e de seu valor como conceito operatório nas análises históricas (epistemologia, histórias positivistas das idéias e arqueologia); 3) o problema específico das formas de investigação da vida no pensamento de Foucault: a arqueologia e 
seus limites em relação à genealogia das formas modernas de objetivação da vida dos indivíduos e das populações pelo poder. Este problema é associado, na terceira parte, à questão da genealogia elaborada por Foucault, em seu pensamento tardio, voltada para a vida pensada como obra de arte.

Este foi o nível em que se situaram minhas análises: o das formas de problematização da vida e das ciências da vida. Apesar de sua heterogeneidade, as formas de problematização privilegiadas tangenciam-se, permitindo configurar uma preocupação e estabelecer uma certa unidade, pois dirigem-se às ciências da vida e ao conceito de vida a partir do pressuposto da historicidade da ciência, do conceito, do saber e do poder. Complementares ou contraditórias entre si, são estratégias históricas que buscam continuidades e descontinuidades, ainda que sua natureza e seu estatuto sejam específicos a cada uma das estratégias, situando-as em níveis diferentes.

A perspectiva apresentada foi, como podemos ver nos ensaios, a do caleidoscópio. O que quero dizer é que o conjunto heterogêneo das abordagens analisadas vai mudando de configuração à medida que giramos o caleidoscópio - as repetições de autores e conceitos nunca são, exatamente, repetições. A cada problema que se coloca - o do vitalismo, o da representação, o do objeto empírico, o da diferenciação dos níveis de análise da epistemologia e da arqueologia, ou da genealogia - modifica-se de acordo com a posição que cada abordagem ocupa em relação às outras. Desta forma, os pensamentos nunca se dão de uma vez; eles vão sendo retomados e se superpondo; a cada movimento, é mais uma dimensão das formas de problematizar as ciências da vida que se evidencia.

Foi assim que reuni, sem reduzir umas às outras, análises como as de Canguilhem, Latour e Salomont-Bayet, estabelecendo correlações. Diante do problema das ciências da vida, a epistemologia de Canguilhem, que se aproxima da história de Jacob, se diferencia da genealogia de Latour, que por sua vez se relaciona com a de Foucault, cuja arqueologia estabelece deslocamentos em relação à epistemologia.

$\mathrm{Na}$ segunda e terceira partes, a pesquisa apresentou uma perspectiva vertical, dirigindo-se à especificação de três níveis: o da epistemologia, o da arqueologia e o das genealogias. No nível da análise epistemológica, as descontinuidades históricas são diacrônicas. Marcam incompatibilidades e mutações, em épocas diferentes, através da recorrência estabelecida a partir do critério da atualidade. No nível arqueológico e da genealogia do poder, trata-se de descontinuidades diacrônicas, que traçam o limiar de épocas diferentes, mas articuladas 
a continuidades sincrônicas que marcam compatibilidades e coerências numa mesma época, através não do critério da recorrência e da atualidade, mas da positividade e da contemporaneidade dos saberes e dos poderes.

Da questão da ciência e da metodologia histórica, a pesquisa passou à investigação de descontinuidades específicas que situam a história do conceito de vida e do surgimento da biologia em níveis específicos. Primeiramente, aquelas estabelecidas por formas de problematização que conduziram ao problema do vitalismo, no nível epistemológico e no nível arqueológico.

Aí, evidenciou-se que, nestes dois níveis de análise, resulta uma visão oposta do vitalismo - como conceito operatório nas ciências da vida, como para Canguilhem e Jacob, ou, ao contrário, como efeito de superfície do nível 'profundo' da arqueologia, onde não pode ser considerado conceito operatório. Contudo, as análises se complementam com diferentes projetos de pesquisa. Esta complementação, que mantém a singularidade de cada projeto, torna-se muito clara, como explicito ao longo do livro, devido à coincidência, nestes dois níveis, de elementos que configuram as descontinuidades por eles apontadas, embora a própria concepção de descontinuidade epistemológica e arqueológica não seja a mesma.

Como fica evidente, os pontos de coincidência são inúmeros: a forma do conhecimento científico e filosófico da época clássica como sendo a mesma, a da representação; a sua incompatibilidade com a forma do conhecimento das ciências empíricas, como as biomédicas, e da filosofia na modernidade, pertencentes a dois diferentes níveis de conhecimento, o dos conhecimentos empíricos e o da filosofia transcendental; a explicitação dos conteúdos da história natural e da medicina clássica, os seres vivos e a doença, como entidades abstratas, ideais; a sua incompatibilidade com os conteúdos da biologia e da medicina moderna, com a vida empírica, concreta, e a doença no corpo concreto do indivíduo; o papel de Cuvier - e não de Lamarck - como marco da biologia, o de Bichat, da medicina, e o de Kant, da filosofia na modernidade; a constituição do conceito de vida somente na modernidade.

No domínio das análises das ciências da vida, as maiores diferenças entre a arqueologia e a epistemologia são mesmo, do ponto de vista do método, as que dizem respeito à natureza e ao estatuto da descontinuidade; do ponto de vista do conteúdo, as que dizem respeito ao valor do vitalismo para a história das ciências da vida e seu papel na articulação entre a filosofia, a ciência e a vida.

Mas esta diferença não pode ser subestimada nem superestimada. Ao considerar o vitalismo um conceito operatório, a análise conceitual, recorrente 
e judicativa termina por exigir da epistemologia que busque, através da relação da filosofia com a ciência, a confirmação de verdades essenciais, ainda que provisórias e parciais. Apesar das dificuldades, cada vez maiores, da posição vitalista, hoje, a própria biologia e sua forma de problematizar a vida permitem a Canguilhem confirmar a consistência de seu vitalismo. Dagognet, a partir do pensamento do próprio Canguilhem, desenvolve tal investigação, levantando a questão "uma ciência da vida é possível?".

O sentido desta questão, formulada por Dagognet, é epistemológico. $\mathrm{Na}$ arqueologia, seu sentido só pode ser outro - como é possível que a ciência da vida exista, pois a arqueologia busca o nível das condições de possibilidade do saber, e não o da verdade e da atualidade. Também não é sua preocupação diferenciar o estatuto do vitalismo em relação à metafísica, à ciência, nem definir animismo, vitalismo, mecanicismo, como fazem, detalhadamente, Canguilhem e Jacob.

Aliás, o vitalismo e sua oposição ao mecanicismo, não são considerados, em As Palavras e as Coisas, em seu caráter de debate ou de cientificidade. O mecanicismo só aparece na arqueologia para descartar a hipótese de que o que caracteriza a época clássica é o mecanicismo presente no racionalismo cartesiano - a tese foucaultiana é que o pensamento de Descartes é emblemático da época clássica por instaurar o pensamento da Ordem. Ao buscar estabelecer regras universais de conhecimento - mathesis universalis e taxonomia -, Descartes funda o conhecimento, em última instância, na ordenação das representações. E é por esta razão que Descartes como fundador dos procedimentos das ciências clássicas, como a história natural, a análise das riquezas e a gramática, que são conhecimentos que comparam e classificam, ordenando as representações; não por sua relação com o mecanicismo, menos ainda por sua relação com a medida, com a matemática que se reduz à ordem. Aliás, o desaparecimento de uma "ciência universal da ordem", característica dos séculos XVII e XVIII, abre um espaço no saber da modernidade para uma 'matematização', como na física, mas, ao mesmo tempo, para uma 'desmatematização', como nas ciências empíricas modernas - biologia, economia política e filologia - e nas ciências humanas. Assim, em sua arqueologia, Foucault situa a física na dimensão da matemática, que não é o lugar onde se enraízam as ciências da vida.

No nível arqueológico, por um lado, as descontinuidades são indispensáveis para definir os limites temporais do saber de uma época e, nela, o aparecimento de novas empiricidades, novos objetos e nova forma dos saberes. Por 
outro lado, são as continuidades entre os diferentes saberes de uma mesma época que delimitam o espaço geral do saber, pois são as relações de diferentes ciências entre si e delas com a filosofia que permitem explicitar a configuração geral do saber numa episteme.

O estudo da noção da representação e da constituição do objeto, na modernidade, permitiu esclarecer esta descontinuidade. Apesar das severas críticas, dirigidas a categorias metodológicas da arqueologia como representação, episteme, a priori histórico, é possível esclarecer seu sentido e seu valor operatório para a história das ciências realizada por Foucault. As análises foucaultianas ficam claras e constituem instrumentos importantes para a determinação arqueológica das condições de possibilidade da constituição do saber moderno e sua crítica como saber antropológico.

O problema do conceito de vida é tratado aqui buscando as formas de investigação da vida no pensamento de Foucault, as formas de problematização que conduziram à interrogação das condições de possibilidade de seu surgimento na modernidade. Primeiro, discutindo a questão do limiar da modernidade, com Kant, e da articulação estabelecida, na arqueologia, da filosofia com as ciências empíricas, as da vida. Em seguida, analisando as formas de problematização da vida em suas condições externas de possibilidade, no nível da relação do saber com o poder, instituído com a genealogia. Finalmente, e apenas como uma complementação, pois já não se trata das ciências da vida, delimitando-as ante o projeto de problematização da vida que se constitui como uma genealogia da ética fundada numa estética da existência.

Se repostas definitivas e fechadas para os problemas apontados não foram apresentadas, isto se deve à complexidade dos temas que aí se interligam. Deve-se à grande erudição de pensamentos que abrangem, simultaneamente, muitas teses, todas elas complexas. São tantas as teses envolvidas que, além de ser impossível tratá-las em sua totalidade, escapa, inteiramente, ao propósito de minha investigação. 



\section{Parte I}

Filosofia, História e Ciências da Vida 
A história do pensamento é a análise do modo pelo qual um campo não problemático da experiência torna-se um problema, suscita discussões e debate, incita novas reações e induz crises em comportamentos, hábitos, práticas e instituições antes silenciosos.

Foucault (2001b) 


\section{1 \\ Formas Históricas de Problematização}

A problematização dos aspectos fundamentais, que constituem aquilo que se compreende por ciências da vida e suas formas de intervenção em nossa sociedade, tem, hoje, como ponto de partida, a necessidade de repensar o otimismo depositado nas ciências, nos últimos séculos, a partir do ideal moderno de objetividade e neutralidade de conhecimento, cujo aperfeiçoamento promoveria o bem-estar social. ${ }^{17}$

A ciência é uma questão que preocupa cientistas e outros intelectuais, apresentando-se, atualmente, não mais apenas como adjuvante lógico e experimental da saúde e da razão, mas como risco e fonte de patologia e mortalidade. Não se discutem mais as revoluções científicas restringindo-se a seu caráter lógico e metodológico. Impõem-se a pesquisa da evolução das ciências, de suas origens, de suas crises assim como a denúncia de seu caráter de violência e de dominação, que delimita novas formas de preocupação com os saberes científicos e suas práticas. A noção de historicidade da racionalidade científica conduz a filosofia das ciências a diferentes abordagens de perspectiva histórica, nas quais se eliminam as concepções de verdade universal e de unidade e de generalidade do método, separando-se regiões de cientificidade, como a região das ciências da natureza, a da vida e a do homem, cada uma apresentando sua especificidade.

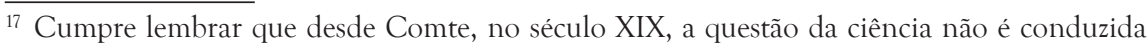
exclusivamente pelas análises dos processos cognitivos. Comte (1978) opera um deslocamento para uma filosofia fundada na história da ciência e sua relação intrínseca com o progresso da sociedade e da humanidade. Ele compreende a ciência como uma teoria que progride, no sentido de uma unidade geral, para uma verdade finalmente positiva, sendo sua gênese racional e psicossociológica. 
As reflexões sobre as ciências conduzidas pelas vertentes que as consideram em sua historicidade, como as epistemologias desenvolvidas no século XX, são avessas ao dogmatismo unitário, metodológico e teleológico da análise de Comte, aprofundando as diferenças entre as histórias críticas das ciências: as que dirigem a análise à racionalidade científica ${ }^{18} \mathrm{e}$ as que dirigem os estudos da ciência às explicações sociais, pressupondo que o caráter real da ciência situa-se para além de seu campo de investigação, isto é, de seu conteúdo. ${ }^{19} \mathrm{O}$ desafio é escapar de um possível reducionismo ao internalismo ou ao externalismo.

Estas duas diferentes formas de pensar as ciências - internalismo e externalismo - recaem numa impossibilidade de diálogo. Para a primeira, não será possível fazer história da ciência, sem se considerarem os elementos propriamente científicos; ao passo que, para a externalista, o mais importante é explicitar a produção científica pelos seus componentes sociais, sem os quais o trabalho do historiador parecerá absurdo. Deste modo, tanto num caso como no outro, a ciência é analisada a partir de uma ruptura entre a comunidade e os conteúdos do conhecimento, de uma redução do social ao exterior das atividades cognitivas. Para pensadores como Canguilhem e Latour, a distinção entre internalismo e externalismo é considerada pouco produtiva e deve ser substituída por uma reflexão sobre as condições históricas da formação destas duas categorias - sua genealogia - com o objetivo de ultrapassar a própria dicotomia.

A partir do século XX, estabelecem-se novas análises da constituição das ciências em termos de condições externas de possibilidade que enfocam as relações entre seu caráter de saber e seu caráter de práticas experimentais, sociais, políticas e econômicas. Ao serem enfatizadas tais relações, as ciências são tomadas como relações de forças que operam em nossa sociedade, consideradas como investidas de responsabilidade política, consideradas como importantes formas de poder que incidem sobre a vida dos indivíduos e das populações e objetivam formas de subjetividade e de natureza.

A epistemologia já não é mais o espaço exclusivo da análise da racionalidade e da linguagem, mas está inteiramente imbricada com as questões ético-políticas. Cada vez mais, busca-se superar as dicotomias sobre as quais se funda o cientificismo, tais como conhecimento e política, ciência e sociedade,

\footnotetext{
${ }^{18}$ Representadas, por exemplo, por Gaston Bachelard, Alexandre Koyré e Georges Canguilhem.

${ }^{19}$ Representadas por Karl Popper e Thomas Kuhn (este último notadamente inspirado em Koyré e Fleck), por exemplo.
} 
teoria e prática, razão e poder, sujeito e objeto, conhecimento e experiência, fato objetivo e sua descrição científica através da representação, dicotomias discutidas ou pressupostas nas teorias do conhecimento ${ }^{20}$ e epistemologias clássicas.

A noção de ato epistemológico não corresponde mais, necessária ou exclusivamente, ao racionalismo clássico, pois a ciência é compreendida como produção técnica de objetos científicos construídos a partir das transformações de fatos em artefatos que funcionam na prática. ${ }^{21}$ As ciências são discutidas do ponto de vista da insuficiência das oposições racionalismo e empirismo ou idealismo e realismo, com o objetivo de determinar as faculdades do sujeito, sua capacidade de produzir representações suscetíveis de objetividade e os limites do conhecimento possível. Esta discussão coloca novas formas de tratar a idéia de que o conhecimento científico é produzido, considerando-o ou bem uma produção a priori, na e pela razão, mesmo que se recorra à experiência empírica, ou bem uma produção a partir do dado empírico, mesmo que, num segundo momento, seja elaborado pela razão. $\bigcirc$ próprio conceito de sujeito de conhecimento dado previamente vem sendo questionado, ${ }^{22}$ e até mesmo a descrição científica dos fenômenos vem sendo considerada como um fenômeno histórico-cultural.

\footnotetext{
${ }^{20}$ As teorias do conhecimento clássicas pesquisam os processos de produção de conhecimento pelo sujeito cognoscitivo na tentativa de explicar a relação entre o sujeito que faz ciência, o objeto de conhecimento e o seu desvelar, a representação ou a produção da verdade científica - como o fizerem Descartes, por exemplo, numa perspectiva idealista e racionalista, ou Hume e Locke, numa perspectiva realista e empirista, ou, mais tarde, Kant, ao buscar as condições de possibilidade do verdadeiro conhecimento, atribuindo-as às categorias a priori do sujeito transcendental.

${ }^{21}$ Observe-se, na região das ciências da natureza, a posição da epistemologia de Bachelard racionalismo aplicado e materialismo técnico - ao rejeitar as análises baseadas num racionalismo que despreza a experiência ou que, como o próprio empirismo, termina por privilegiar a atitude racionalista. Sua crítica estende-se à noção, implícita ao racionalismo clássico dos filósofos, de que os princípios da razão são absolutos, a priori, e, por isso, determinantes do funcionamento da ciência (Bachelard, 1949).

${ }^{22}$ Note-se a proposta de Foucault, inspirada em Nietzsche, de analisar o sujeito de conhecimento rejeitando a noção cartesiana de sujeito como fundamento já dado e que seria o ponto de origem a partir do qual o conhecimento é possível e a verdade aparece. Foucault propõe-se a estudar como se dá, ao longo da história, a constituição de um sujeito do conhecimento no interior mesmo da história, portanto de um sujeito que não pode ser considerado como uma unidade dada previamente ao ato do conhecimento, mas que é fundado pela história. Tal proposta constitui forte tendência do pensamento do século XX e vem sendo reforçada até nossos dias; ela objetiva mostrar como as práticas sociais podem chegar a engendrar domínios de saber que fazem nascer formas totalmente novas de sujeitos de conhecimento: "O próprio sujeito de conhecimento tem uma história, a relação do sujeito com o objeto, ou, mais claramente, a própria verdade tem uma história” (Foucault, 1999: 8).
} 
As tendências mais recentes desenvolvem a noção de ciência contingente e circunstancial, conferindo às ciências um estatuto semelhante a outras manifestações culturais. Às ciências, pode-se, portanto, atribuir um valor de comprometimento político, enquanto consideradas como fazendo parte de uma rede de relações de forças. Neste caso, analisam-se séries de fatores externos à sua constituição lógica. Enquanto fenômenos culturais, entende-se que as ciências são constituídas não só de práticas sociais, mas de práticas de laboratório que precisam ser analisadas através de observações sobre as atividades aí desenvolvidas, para integrar todos os aspectos do fazer ciência e compreender sua complexidade buscada na ação empírica, algumas vezes até mais do que nas idéias. ${ }^{23}$ Trata-se, então, de pesquisar práticas locais, relacionando-as com os instrumentos, os materiais, os conceitos e o saber.

Constata-se, assim, que a concepção e o valor de ciência são surpreendentemente plurais. Vão desde sua compreensão como um sistema de conhecimento puramente teórico e neutro até a de ciência como prática política. No primeiro caso, à ciência atribui-se o valor de verdade objetiva, isenta de subjetividade e de interesses políticos - expressão máxima da razão positiva situada do lado do bem, das técnicas e dos remédios, continuamente salvadora - conforme ocorre tradicionalmente.

De acordo com a tradição, pode-se afirmar que se entende por ciência o conjunto das aquisições intelectuais das matemáticas e das disciplinas da investigação do dado natural e empírico, que podem ou não fazer uso das matemáticas, mas tendendo sempre à matematização. A ciência consiste, então, num conhecimento constituído por conceitos, juízos e raciocínios, obedecendo a regras lógicas de um conjunto ordenado de proposições, para alcançar, objetivamente, a verdade dos fatos, através da verificação experimental da adaptação das idéias aos mesmos.

Deste ponto de vista, os enunciados confirmados são considerados representações dos dados empíricos e são obtidos numa relação com a teoria, constituindo matéria prima da elaboração teórica e transcendendo os fatos para produzir novos fatos e explicá-los. A investigação científica não se limita, portanto, aos fatos observados, mas os seleciona, controla e reproduz. A experiência é racionalizada através de teorias, hipóteses e conceitos. As análises históricas e filosóficas das ciências devem-se constituir, então, de métodos capazes de analisar e julgar tais elementos.

${ }^{23}$ Cf. as análises das ciências de Latour realizadas a partir do estudo das práticas em laboratório (Latour, 1979, 1983, 1987, 1994, 2001). 
Outra perspectiva de análise do conhecimento científico parte do pressuposto platônico que opõe episteme e doxa, ciência ou conhecimento verdadeiro e opinião ou conhecimento do senso comum. Tradicionalmente, a ciência é considerada o lugar da verdade por excelência por se fundar no logos, na razão, especificada a partir da ciência moderna pela exigência de objetividade e experimentação. Desta concepção resulta o projeto de investigação do modo como o conhecimento científico é alcançado através do abandono total do conhecimento da opinião, conforme propõe Bachelard (1989), ou por meio de um processo de purificação, como explica Popper (1972). Porém, freqüentemente, este sentido é controvertido e até considerado irrelevante para a filosofia da ciência. A concepção mais corrente e tradicionalmente aceita nem sempre é considerada a melhor e parece um dos pontos mais afastados do atual debate sobre a ciência.

Daí a importância da investigação de formas de problematização das ciências da vida a partir da questão "o que é ciência e em que consistem os procedimentos de análise de sua historicidade?”. Daí o interesse em traçar um perfil de algumas das formas que constituem uma base para a fundamentação do atual questionamento da vida e das ciências neste domínio de saber.

Para pesquisar as formas atuais de problematizar as ciências da vida e a vida, mostra-se necessário, antes de mais nada, descrever algumas modalidades de questionamento, complementares ou contraditórias entre si - epistemologia, arqueologia, genealogia, história multidisciplinar - que se tangenciam por seu caráter histórico e pelo privilégio da busca das descontinuidades históricas encontradas nos processos de produção científica. A hipótese aqui discutida é que, apesar de nem a natureza e o estatuto das descontinuidades históricas nem os níveis em que estas modalidades de análise se situam para tratá-las serem o mesmo, é possível traçar uma preocupação - até certo ponto homogênea - com o tema das ciências da vida.

É neste sentido que as questões dirigem-se à relação que se estabelece, na região das ciências da vida, entre a metodologia histórico-filosófica e as ciências em termos de objeto, objetividade, interdisciplinaridade, verdade, prática e relações de forças. Georges Canguilhem, Michel Foucault, Michel Serres (1992), François Jacob (1983), Bruno Latour, Claire Salomont-Bayet (1986) são emblemáticos desta forma de preocupação originada no século XX. 



\section{2}

\section{Conceitos e Forças: objeto da história das ciências segundo Canguilhem e Latour}

Ao refletir sobre a história e a filosofia das ciências, Georges Canguilhem (1970a) ${ }^{24}$ mostrou, claramente, que uma questão prévia se fazia necessária: de que a história das ciências é história? Embora já na década de 1960 a resposta pudesse parecer óbvia, filósofos, historiadores e sociólogos das ciências estavam longe de a terem encontrado ou de chegarem a algum consenso. Ainda hoje continuam a discuti-la com base em pressupostos metodológicos bastante diferentes. A afirmação de Latour (1984) de que, em história das ciências, nenhuma explicação escapa à análise das relações de forças, reforça a pertinência e a complexidade da questão que Canguilhem levanta e procura elucidar através da crítica às perspectivas internalistas e externalistas em história das ciências. Hoje, sem dúvida, tal questão continua impondo aos historiadores das ciências a reflexão filosófica a respeito de seu objeto.

\section{Conceito E historicidade SEgundo CANGUILHEM}

De acordo com Canguilhem (1970a: 11) - para quem "sem referência à epistemologia, uma teoria do conhecimento seria uma meditação sobre o vazio e que, sem relação à história das ciências, uma epistemologia seria uma duplicação perfeitamente supérflua da ciência sobre a qual pretende discorrer" 25 - o objeto da história das ciências reside no conceito, em sua historicidade. O epistemólogo a ele se refere da seguinte maneira:

\footnotetext{
${ }^{24}$ Esse texto foi escrito a partir de seus estudos no Institut d'Histoire des Sciences et de Technologie de l'Université de Paris, nos anos 1964-6, e de sua conferência, realizada em Montréal, a convite da Societé Canadienne d'Histoire et de Philosophie des Sciences, em 1966.

25 Tradução minha de todas as citações desta obra.
} 
A história das ciências se exerce sobre estes objetos segundos, não naturais, culturais, mas não deriva deles do mesmo modo que eles não derivam dos [objetos] primeiros. O objeto do discurso histórico é, com efeito, a historicidade do discurso científico, enquanto esta historicidade representa a efetuação de um projeto interiormente normatizado, mas atravessado por acidentes, retardado ou desviado por obstáculos, interrompido por crises, quer dizer, momentos de julgamento e de verdade. (Canguilhem, 1970a: 17)

O conceito não é uma palavra, mas uma denominação, uma definição, um nome dotado de um sentido capaz de interpretar as observações e as experiências. É uma interpretação; não existe propriamente falando a não ser onde existe, pelo menos em esboço, uma relação entre um definens e um definierum. É evidente que a ciência não se restringe ao conceito. Entretanto, por sua função de operador na produção do conhecimento científico, é o conceito que garante a eficácia teórica ou o valor cognitivo da ciência, encerrando uma norma operatória ou judicativa que não pode variar sem a retificação de sua compreensão. Seu valor operatório reside na possibilidade que oferece de desenvolvimento e de progresso do saber - a própria experimentação depende de sua produção. Não se trata, entretanto, de teoria; teoria e conceito não se confundem. A teoria consiste num conjunto de conceitos que formam um sistema, dentro do qual o conceito apresenta a formulação de um problema, enquanto a teoria, a sua resposta.

O que a epistemologia explicita é uma inter-relação conceitual a ser analisada: relação de um conceito com outros conceitos de uma mesma teoria, ou de teorias diferentes de uma mesma ciência, ou de ciências diferentes, ou, ainda, relação de um conceito com saberes não científicos; o conceito pode se relacionar, também, com o nível das práticas sociais e políticas. Por conseguinte, um conceito não se restringe ao interior de uma determinada ciência; segundo Canguilhem, pode, inclusive, nascer antes de se tornar científico. O surgimento de um conceito e a definição dos critérios de cientificidade são duas coisas diferentes, uma vez que sua formação não se subordina, necessariamente, à instauração da cientificidade, mas à sua própria condição de possibilidade. Compreendê-lo requer uma análise que dê conta de suas inter-relações.

O conceito não pode, portanto, ser compreendido através de uma razão histórica extrínseca à ciência, discurso verificado sobre um setor delimitado da experiência que residiria nas comemorações, nas rivalidades em termos de paternidade intelectual, nas querelas. Para Canguilhem, os procedimentos 
desta razão teriam sido utilizados para justificar a existência da Instituição, da Academia e dos fatos acadêmicos, contra os quais se posiciona ao evidenciar suas extrapolações práticas e tecnológicas.

Também não é através de uma razão mais expressamente científica que é alcançado; pois o objeto da história das ciências não deve ser confundido com um objeto científico, com um resultado teórico ou experimental justificado, historicamente, pelo próprio cientista que tenta, assim, explicar uma conclusão até então inconcebível e que, por impossibilidade de comunicação na cidade científica numa dada época, a busca no predecessor, partindo, é claro, da crença na objetividade de sua descoberta e no fato de que aquilo poderia ter sido pensado no passado, o que ocorreu quando Hugo Vries (1848-1935)26 redescobre o mendelismo e Mendel (1822-1884).

Se existissem precursores, a história das ciências perderia todo sentido. A dimensão histórica da ciência seria apenas uma aparência, visto que um precursor seria um pesquisador que teria percorrido, no passado, um trecho de um caminho finalizado, recentemente, por um outro. Se, na Antigüidade, quando o mundo era considerado fechado, alguém tivesse podido ser, em cosmologia, o precursor de um pensador da época do universo infinito, um estudo como o de Alexandre Koyré (1957) seria impossível. O precursor seria um pensador que o historiador poderia retirar de seu enquadramento cultural para inserir num outro enquadramento, o que corresponderia a considerar que conceitos, discursos e gestos especulativos ou experimentais podem ser deslocados num espaço intelectual onde a reversibilidade das relações deve-se ao esquecimento do aspecto histórico do objeto.

Ao afirmar que não há precursores, Canguilhem estabelece uma nova relação da história das ciências com a epistemologia, opondo-se à idéia de história como sua memória e seu laboratório, como 'microscópio mental', o que pressuporia que a relação da história das ciências com as ciências fosse do mesmo tipo da relação das ciências com seus objetos. Esta concepção de história baseia-se na tese de que existiria um método geral universal e eterno, pouco ativo em algumas épocas, mais ativo em outras. Canguilhem denuncia o positivismo desta idéia: em primeiro lugar, devido a seu racionalismo geral que contradiz o pressuposto de um racionalismo regional, segundo o qual existem diferentes regiões de cientificidade, com especificidades e método próprio; em segundo lugar, porque, ao ser conduzida pela imagem do microscópio à noção

\footnotetext{
${ }^{26}$ Hugo de Vries é um botânico holandês, autor de uma teoria sobre o crescimento das plantas e suas mutações.
} 
de laboratório, a história das ciências teria apenas a função de conferir duração à exposição dos resultados científicos alcançados. A história das ciências permitiria, assim, uma parada e um distanciamento do conhecimento científico, seria como um aparelho de detecção de objetos já constituídos.

Contrário ao positivismo, o epistemólogo afirma: ${ }^{27}$

Ao modelo do laboratório, pode-se opor, para compreender a função e o sentido de uma história das ciências, o modelo da escola e do tribunal, de uma instituição e de um lugar onde se fazem julgamentos sobre o passado do saber, sobre o saber do passado. Mas é necessário aqui um juiz. A epistemologia é que é chamada a fornecer à história o princípio de um julgamento (...). (Canguilhem, 1970a: 2)

O julgamento do passado do saber reconhece que toda verdade é sempre provisória, é sempre uma ultrapassagem. Compete, pois, à epistemologia fornecer o princípio judicativo da produção de verdades, princípio fundado na verdade mais atual da ciência "última linguagem falada pela ciência, permitindo recuar no passado, até o momento em que esta linguagem deixe de ser inteligivel ou passível de ser traduzida numa outra linguagem anteriormente falada" (Canguilhem, 1970a: 13), momento em que detectamos uma ruptura, o surgimento de uma nova questão. Como ocorreu com Lavoisier (1743-1794) que, ao compreender que estava fundando um novo saber, marca um intervalo entre sua química e a ciência anterior, cortando qualquer relação com a língua falada por seus mestres e negando qualquer histórico da opinião daqueles que o precederam. Evidentemente, isto não significa que os cientistas tenham necessidade, para o trabalho científico, da história das ciências, da epistemologia ou da genealogia. Eles precisam apenas de um mínimo de filosofia, sem a qual não poderiam falar de suas ciências com interlocutores não-cientistas.

Podemos, então, compreender a diferença que a epistemologia francesa estabelece, a partir de Gaston Bachelard, entre a história dos conhecimentos ultrapassados e a dos conhecimentos sancionados, ainda atuais porque ativos, cuja função e sentido judicativos têm como ponto de partida a relação com os valores científicos mais recentes, com a verdade mais atual da ciência.

\footnotetext{
${ }^{27}$ Em conversa com Bruno Latour, Michel Serres opõe-se inteiramente ao modelo do julgamento proposto por Canguilhem, rejeitando a tese mais fundamental da epistemologia francesa: "Como eu tinha abandonado a epistemologia, abandonei, igualmente toda perspectiva de julgamento. A crítica nunca é fecunda, e a avaliação das ciências não é sequer possível, tão rapidamente flutuam. Ainda presa à instituição, a crítica é fácil, temporária, fugitiva, rapidamente ultrapassada. Se a verdade de ontem torna-se o erro do dia seguinte, acontece também nas ciências aquele dia em que o erro condenado se encontre, mais cedo ou mais tarde, no tesouro dos grandes achados" (Serres, 1992: 82). Tradução minha.
} 
A história das ciências não é o progresso das ciências invertido, quer dizer, a colocação em perspectiva de etapas ultrapassadas para a qual a verdade de hoje seria o ponto de fuga. Ela é um esforço para pesquisar e fazer compreender em que medida noções ou atitudes ou métodos ultrapassados foram, em sua época, uma ultrapassagem e, por conseguinte, em que o passado ultrapassado continua como passado de uma atividade científica à qual é necessário conservar o nome de científica. Compreender o que foi a instrução do momento é tão importante quanto expor as razões da destruição seguinte. (Canguilhem, 1970a: 14)

Tais considerações conduzem, inevitavelmente, à questão daquilo que os filósofos da ciência anglo-saxões designam de externalismo e internalismo em história das ciências. Vejamos o argumento de Canguilhem. Por um lado, o internalismo - considerado pelos externalistas um idealismo - afirma que só há história das ciências quando nos colocamos no interior da obra científica para analisar os procedimentos com os quais ela tenta satisfazer as normas específicas que permitem defini-la como ciência e não como técnica ou ideologia. Nesta perspectiva, o historiador deve adotar uma atitude teórica a respeito daquilo que é considerado fato de teoria e, por conseguinte, utilizar hipóteses ou paradigmas do mesmo modo que os cientistas. Por outro lado, o externalismo condiciona um certo número de acontecimentos, que continuamos a chamar de científicos mais por tradição do que por uma análise crítica, analisando-os através de suas relações com interesses econômicos e sociais, de exigências práticas e técnicas ou de ideologias religiosas ou políticas, o que epistemólogo chama de marxismo enfraquecido realizado nas sociedades ricas.

Nos dois casos, afirma Canguilhem, o objeto da história das ciências é assimilado ao objeto da ciência, o que invalidaria os dois modos de investigação. No internalismo, porque a história vê, nos fatos da história das ciências, fatos que só podem ser tratados teoricamente, alinhando-os sobre os fatos científicos, confundindo-os e conferindo à história um caráter ambíguo. No externalismo, porque a história funciona como uma explicação de um fenômeno cultural através do condicionamento ao meio cultural global, como a sociologia naturalista que negligencia o problema da interpretação de um discurso com pretensão à verdade.

Para a epistemologia francesa, o objeto da história das ciências consiste na historicidade da ciência, pois a historicidade é a própria efetuação de um projeto interiormente regulado, atravessado por acidentes, retardado ou desviado por obstáculos, interrompido por crises, por momentos de julgamento 
e de legitimação de verdades. Ora, tal objeto não é dado, mas diz respeito a uma decisão filosófica que não advém das ciências nem de um possível objeto natural. $\mathrm{O}$ historiador das ciências constitui seu objeto, que lhe é próprio, a partir do estado atual das ciências, estado que não é a conseqüência lógica direta de uma ciência, nem de dados da história global e que diz respeito a um grupo de ciências sem coesão intrínseca, bem como à ideologia e à prática política e social. O lugar teórico deste objeto é a epistemologia que investiga as questões teóricas suscitadas pela prática do saber em seu devir.

Canguilhem o explicita com o exemplo de Mendel, que teria inventado ligações imprevistas das matemáticas com práticas não científicas como a seleção, a hibridação, a orientação. Suas invenções consistiriam em respostas às questões levantadas por ele mesmo, através de uma linguagem que teve de estabelecer. $\mathrm{O}$ estudo crítico da formulação das questões como estas constitui o objeto da história das ciências que apresenta, deste modo, dois níveis: por um lado, o dos documentos a catalogar, dos instrumentos a descrever, dos métodos e questões a interpretar, que não é considerado o mais relevante; por outro lado, o nível dos conceitos, privilegiado pela epistemologia francesa, pois um novo conceito encerra uma nova questão, sendo, por isto, considerado a principal mola propulsora da produção científica. Sem os conceitos, explica Canguilhem, não há ciência, pois não se realiza uma atividade axiológica, e a história das ciências é, por excelência, uma busca da verdade. Contudo, a história das ciências não pode ser uma ciência, e seu objeto não pode ser científico.

A história dos instrumentos ou das academias só é história das ciências quando se relacionam seus usos e seus destinos com teorias. Entretanto, uma história dos resultados do saber - das teorias - não passa de um registro cronológico. A história cronológica dos instrumentos ou dos resultados pode obedecer aos períodos da história geral. Porém, o tempo da produção da verdade científica tem uma cronologia própria, diferente em cada disciplina; de tal modo que a história das ciências, que é a da relação progressiva da inteligência com a verdade, estabelece uma cronologia de acordo com o progresso da produção de verdades científicas, obedecendo às suas rupturas, às suas continuidades e descontinuidades, no nível dos conceitos, das questões, em que a atividade científica aparece como tal. 


\section{ForÇAS E ÂNGULO DOS DESLOCAMENTOS SEGUNDO LATOUR}

Na virada do século XIX para ao século XX, o problema da dicotomia internalismo versus externalismo parece não se ter dissipado. Latour, para quem nenhuma explicação histórica das ciências escapa à análise das relações de forças, nega a eficácia destas duas perspectivas e propõe um método para ultrapassar a própria dicotomia, visando a recompor nosso mundo, dividido em ciência, natureza e sociedade.

Ninguém pode separar a história interna das ciências da história externa de seus aliados. A primeira não é absolutamente história, é na melhor [hipótese] a historiografia da corte, na pior é A Lenda Dourada. Quanto à segunda, não é história das ciências; é história tout court. (Latour, 1984: 245$)^{28}$

O projeto de Latour é o de uma exegese, uma interpretação de textos, da literatura científica que identifica razão e força, ${ }^{29}$ através de uma história que é, ao mesmo tempo, empírica (trata dos micróbios, dos microbiologistas e das sociedades pastorianas), filosófica, teórica e agnóstica em termos de ciência. Seu objetivo consiste em pensar a ciência afastando-se do nosso ideal de decidir a partir do privilégio das relações de razão. Latour nega aquilo que, segundo ele, constitui, hoje, nossa única transcendência: as provas irrefutáveis, a eficácia indiscutível, multiplicadas pelo Iluminismo, no qual não podemos mais acreditar, pelo perigo, pela violência e pela política dele resultantes. Trata-se de pensar de outro modo, sem repetir o engano de separar ciência e política.

Apesar da tradição, ainda com base nesta separação, busca-se uma história da influência da sociedade, das culturas, das paixões políticas sobre a evolução das teorias científicas ou dos progressos tecnológicos. Porém, com o exemplo da revolução pastoriana, Latour quer provar que tanto a ciência quanto a sociedade podem ser mais bem esclarecidas analisando-se as relações de forças que se tornam opacas quando se segue tal divisão.

Este exemplo não pode ser explicado nem pelas influências exercidas sobre Pasteur, nem pelas condições sociais que aceleraram ou retardaram seus sucessos, na medida em que privilegia apenas o componente social. Também não pode ser explicado através da paráfrase dos resultados científicos que

\footnotetext{
${ }^{28}$ Tradução minha de todas as citações desta obra.

29 O modelo desta exegese proposta por Latour é de Espinoza, que estabelece a democracia 'na' razão, quando inventa a exegese bíblica e identifica direito e força. A própria forma da parte filosófica do livro - Irreduções (Latour, 1984) - inspira-se na Ética de Espinoza, desenvolvendose, como na geometria, através de proposições, demonstrações e scolies.
} 
privilegia o componente científico. $\mathrm{O}$ interessante é que, para Latour, estas duas perspectivas são dois monólogos - não há entre elas diálogo possível. O problema é que, em história das ciências, não se deve fazer uma redução sociológica, pois é preciso dar conta do conteúdo técnico, mas também não se pode recorrer às palavras usadas e a serem estudadas pelas pessoas (prova, verdade, eficácia, demonstração, realidade, revolução); nos dois casos estaríamos distinguindo dois blocos.

Nos anos 80, Latour explicita sua proposta: ${ }^{30}$ fazer uma genealogia da Razão, através da qual é possível recuar até o momento em que se separaram e hierarquizaram as relações de forças e as de razão, que, para ele, são inseparáveis.

O que acontece, então, se negamos esta diferença e nos colocamos a seguir apenas as relações de forças? (...) Seria necessário poder mostrar em parte que a ciência e a sociedade são, ambas, explicadas por uma análise que segue apenas as relações de forças, e que estas se tornam mutuamente inexplicáveis e opacas quando nos esforçamos em separá-las. (Latour, 1984: 12)

Ao afirmá-lo, assume o modelo político da batalha, inspirado em Tolstoi (1869).

Tolstoi convoca centenas de personagens para aprofundar esta questão para ele essencial: o que pode um homem? $\mathrm{O}$ que faz realmente um grande homem como Napoleão ou Koutouzov? São-lhes necessárias cerca de oitocentas páginas para restituir às multidões a eficácia que os historiadores de seu século colocavam na virtude ou no gênio de alguns homens. Tolstoi conseguiu, e toda história recente apóia suas teorias sobre a importância relativa dos grandes homens em relação aos movimentos de conjunto que se representam ou se desviam em algumas figuras epônimas. (Latour, 1984: 19)

É a partir da denúncia do caráter arbitrário da Razão que Latour afirma o modelo da guerra, ao qual é necessário atribuir um princípio de projeção que permita seguir os contornos múltiplos e imprevisíveis das forças envolvidas, que não se dão a priori. As diversas definições de força encontradas em ciências e em filosofia, afirma Latour, são insuficientes: as aristotélicas (que querem a

\footnotetext{
${ }^{30}$ Em Les Microbes: guerre et paix (Latour, 1984), lança as bases filosóficas de seus estudos da década de 1990 em diante, na linha do Programa Forte de Sociologia. Por exemplo, em Science in Action: how to follow scientists and engineers through society (1987), em Nous N'Avons Jamais Été Modernes: essay d'anthropologie symétrique (1991) e, na linha da etnopsiquiatria, "Em como passar sem a interioridade e a exterioridade", de seu livro Petite Réflexion sur le Culte Moderne des Dieux Faitiches (1996).
} 
realização da forma que dorme em potência), as malthusianas ou darwinistas (que querem sempre mais a mesma coisa e que invadiriam o mundo com seu crescimento exponencial se outras, também ávidas, não as interrompessem), as newtonianas (querem sempre a mesma coisa e caminham sempre com o mesmo passo, desde que as deixemos em paz), as freudianas (que buscam sempre aquilo que poderiam querer, deslocam-se, substituem-se, metamorfoseiam-se ou paralisam-se diante da necessidade), e as nietzschianas (teimosas, porém plásticas, sempre produzindo vontades para lhes dar forma).

O projeto de uma genealogia na linha de Nietzsche parece, contudo, ganhar sentido: recuar, através da filosofia, até o momento em que se separaram saber e poder. As explicações, segundo as quais saber e poder são colocados em pólos opostos e dispostos de acordo com a hierarquia dual dos valores e em que se sobrepõem as noções de verdade, ciência e objetividade, de um lado, e erro, sociedade, política e subjetividade, do outro, são abandonadas.

Em Nietzsche, a Genealogia e a História (Foucault, 1982), explica-se o pensamento genealógico como um trabalho histórico meticuloso e documental, cujos objetivos são marcar a singularidade dos acontecimentos para reencontrar diferentes cenas, onde papéis distintos foram desempenhados, e, sobretudo, definir o ponto de lacuna onde não aconteceram mais. Foucault nega a noção de desdobramento meta-histórico das significações ideais e das teleologias indefinidas, em nome de uma concepção de origem bastante específica.

A genealogia se opõe à pesquisa da origem, quando tomada como fundamento originário metafísico, como essência exata da coisa, isto é, como forma pura, imóvel e anterior a tudo o que parece externo, acidental e sucessivo. Para ele, aquilo que se encontra no começo histórico das coisas não é a identidade ainda preservada da origem, mas a discórdia, as invasões, as astúcias, os disfarces, as lutas. O genealogista escuta a história, buscando atrás das coisas algo diferente da razão, da 'visão altiva' e profunda do filósofo ou da dedicação à verdade e ao rigor dos métodos científicos. Para Foucault, a Razão teria nascido de uma maneira inteiramente distinta. Ele procura o ponto de surgimento, a emergência, restabelecendo os diversos sistemas de submissão: não a potência que antecipa um sentido, mas o jogo casual das dominações. A emergência de um acontecimento, explica Foucault, se produz sempre em um determinado estado de forças. Analisá-la é mostrar de que maneira as forças lutam entre si.

Sem dúvida, Latour confirma tal visão de genealogia, quando a assimila ao modelo de Tolstoi. Analisar a origem da Razão - filosófica e científica - 
é mostrar de que maneira as forças lutam entre si. Na reconstrução de Les Microbes: guerre et paix (Latour, 1984), o princípio de simetria das forças é que justifica a eliminação das hierarquias, das assimetrias ontológicas para a superação da dicotomia ciência e sociedade. Neste estudo da revolução pastoriana, a concepção tradicional de ciência pastoriana e da luta travada por Pasteur contra os micróbios sofre uma imensa reviravolta.

De acordo com Latour, não se pode saber, previamente, qual é o estado das forças, nem o que é uma força. Não se pode saber quando vai ceder, reforçar-se, enfraquecer-se ou desdobrar-se. Contudo, todos nós gostamos de jogar com campos de forças e de fraquezas que só conhecemos no ato da manipulação dos materiais, graças à qual aprendemos o que é forte e fraco, real e irreal, associado e dissociado. Latour critica a tentativa de estabelecer o tamanho relativo das matérias, sua importância, sua ordem de precedência, porque, do seu ponto de vista, o tamanho da matéria é sempre o mesmo, e nenhuma matéria pode ser considerada mais complexa, mais múltipla, mais real, mais palpável ou mais interessante do que a outra. Trata-se de um materialismo que se afasta do materialismo tradicional para o qual a matéria é homogênea e as forças - que são únicas - são imateriais.

Para a história tradicional, a revolução pastoriana seria o exemplo mais indiscutível da Razão elevada acima das relações de força, do social. Entretanto, para Latour, este exemplo mostra a história da bacteriologia como a história de uma série de inversões das relações de forças, fundada na lógica dicotômica. Para ele, é preciso seguir todas as forças, todos os personagens e todos os espaços que compõem esta revolução, evitando, por um lado, toda redução das forças - umas às outras, à razão ou ao seu caráter sociológico - e, por outro, a elisão de conteúdos técnicos.

A noção de objetividade, no sentido de correspondência a um objeto externo natural ou produzido, distinto do sujeito que conhece, que se refere ao manipulável ou ao que pode ser manufaturado ou percebido pelos sentidos, é uma noção que desaparece ao ser afirmado o papel desempenhado pelo objeto não como coisa, mas como agente, como força. O objeto é, assim, uma forma que deve ser entendida através da ação desempenhada numa rede móvel de inter-relações de atores, de ações, de respostas escritas e de testes que não têm essência ou ontologia.

É este o argumento de Latour: as bactérias, as enzimas, os elementos, as partículas, que saem dos laboratórios, definem-se por operações que geram inscrições a eles associadas. O número, a natureza, os poderes dos atores não são 
permanentes, mas transformados por traduções e pelo estado da rede - pelas inter-relações dos porta-vozes que a constituem. Sua realidade depende do que dizem os enunciados, a não ser quando se manifesta uma resistência, quando os efeitos de uma ação entram em conflito com associações já estabelecidas.

Sem dúvida, antes de ser colocado em cultura bacteriana, a única forma de existência do micróbio é metafísica. Mas, em cultura, é um objeto construído, cujo nome não representa um ser, mas um novo regime dos discursos e das ações. Seu poder advém de uma forma naturalizada que permite designar os efeitos produzidos pela mobilização dos materiais e dos instrumentos, pela aquisição do saber-fazer, bem como pelas discussões entre os humanos. Aí, a questão que importa é o que é força, o que é estado de força que não se pode conhecer a priori, pois o que existe são campos de forças e fraquezas móveis.

As noções de estado de natureza e de estado de sociedade são duas conseqüências simétricas da ação dos pesquisadores para alinhar humanos e não-humanos. Assim, resta a esta história perseguir, com o ponto de vista das "irreduções", os atores, os deslocamentos por eles operados, as cadeias de traduções e as alianças. Ator e força são conceitos que recobrem os humanos e os não-humanos naturais ou sociais, através de uma listagem de ações, de respostas escritas e testes. Devido ao princípio de simetria, mantêm-se séries de competências e de propriedades que os agentes são capazes de apontar uns em relação aos outros. Desta forma, segundo Latour, eliminam-se as hierarquias e as assimetrias ontológicas.

Na revolução pastoriana, o micróbio de Pasteur e os atores humanos são forças irredutiveis que desempenham papéis simétricos e específicos. São "quase-objetos" concebidos não como entidades fixas, mas como fluxos circulando numa rede de relações. Neste sentido, o micróbio age e dispõe de todas as qualidades geralmente atribuídas aos humanos - tem necessidades e afinidades; é um aliado que faz escolhas e oferece a Pasteur toda a força de um ser autônomo. Este é o micróbio descoberto e modificado por Pasteur.

Latour mostra que, no século XIX, os pastorianos, além de produzirem, através da experimentação e do teatro da prova, a possibilidade da formação do micróbio variável em virulência no laboratório, dividiram os atores envolvidos neste processo em natureza, ciência e sociedade. No século XX, afirma, foi necessário, então, redistribuir o que pertence à natureza, à ciência e à sociedade, com base no ideal contemporâneo de decidir a partir da Razão - então considerada única provedora de provas irrefutáveis - mais do que com base nas relações de forças. O objetivo de Latour é fazer esta redistribuição de outro 
modo, baseando-se na idéia de que todos os elementos em jogo compõem, igualmente, o mundo. Compreende-se, assim, que o mundo é constituído de atores, provas, deslocamentos, vontades, interesses, e traduções. Deste modo, a única forma de reconstituir sua história é determinar as forças envolvidas e seus ângulos de deslocamento, que, certamente, não são encontrados na Razão, mas naquilo que cada ator diz dos outros atores.

Evidencia-se, assim, que a questão do objeto da história das ciências da vida diz respeito não exatamente ao problema do caminho a ser seguido para solucionar a ineficácia das perspectivas internalistas e externalistas - ineficácia evidenciada por Canguilhem e por Latour - mas diz respeito, sobretudo, à relação necessária de seu método da história das ciências com a crítica filosófica. Temos, assim, um objeto que não pode ser confundido nem com o objeto da ciência nem com o da história geral. Por um lado, o objeto é obtido a partir da hipótese de uma análise centrada no conceito e sua historicidade do conceito, como propõe Canguilhem, obedecendo ao modelo do julgamento da verdade científica. Por outro lado, o objeto é obtido a partir da hipótese de uma genealogia da Razão associada ao modelo da batalha de Latour, que pretende fazer uma nova composição do mundo onde não se separam razão e força, centrada nesta última e no ângulo de seus deslocamentos. Trata-se, nas duas hipóteses, de um objeto específico, construído pela história das ciências. 


\section{3}

\section{Método em Salomont-Bayet, Jacob e Latour}

Este ensaio é uma breve reflexão sobre alguns pressupostos metodológicos que se complementam para mostrar um perfil da preocupação histórica com as ciências da vida. Trata de questões de método de pesquisa nesta área, com base na história da microbiologia. Seu ponto de partida é a pesquisa da introdução do modelo microbiano no Brasil.

O primeiro passo dado neste sentido e que orientou esta análise foi o estudo dos elementos constitutivos da microbiologia analisados por Claire Salomon-Bayet em Pasteur et la Révolution Pastorienne, ${ }^{31}$ cujo objetivo é compreender como, no século XIX, acrescentou-se ao olhar médico, que Foucault (1977) concebia como elemento constitutivo da clínica, uma estratégia do invisível, que transformou não somente a relação do médico e do cientista com o corpo - são ou doente - mas também a relação do corpo com o mundo. Salomon-Bayet assinala que é necessário partir de uma compreensão da noção de biologia, independente da idéia de aplicação e de exploração sistemática dos microorganismos. Ou melhor, é preciso analisar o processo da pesquisa biológica que estará na origem de uma eficácia terapêutica, levando em consideração a idéia de que a constituição do objeto biológico corresponde a uma substituição dos sistemas doutrinários - metafísica - pelo esforço de uma formulação de teorias científicas. Para que a microbiologia seja possível, afirma, é necessário, por um lado, que a noção de micróbio surja na exploração sistemática dos microorganismos para construir, teoricamente, seu objeto, submetendo-o à experimentação; por outro, que o termo biologia deixe de indicar uma especulação filosófica ou uma limitação experimental.

\footnotetext{
${ }^{31}$ A partir daqui Pasteur e a Revolução Pastoriana (Salomont-Bayet, 1986). Tradução minha.
} 
Ora, deve-se destacar que, em grande parte da bibliografia em história da microbiologia e das ciências da vida no pensamento francês, a análise dos procedimentos para pensar o surgimento da microbiologia e a revolução pastoriana deve levar em conta os pressupostos metodológicos e os resultados apresentados não só por Foucault $(1969,1977,2002)$ e Jacob (1983), conforme explicita Salomon-Bayet, mas também, por Canguilhem (1963a, 1963b, 1970a, 1975, 1994a), Latour (1984, 1987, 1988, 1991, 1997) e por outros que contribuem com as análises neste campo.

\section{História multidisciplinar de SAlomont-Bayet}

A questão do pensar a revolução pastoriana (Salomont-Bayet, 1986) destaca-se por sua proposta de identificar, reconhecer e explicar as modalidades de difusão e de influência da primeira revolução biomédica - a pastoriana - que afetou sistemas de pensamento e estruturas sociais, transformou a medicina, a cirurgia, a higiene, o ensino, a legislação, a saúde pública, inaugurando a era da medicina científica. Seu ponto de partida é a convicção de que um problema de história das ciências deve ser tratado através de várias histórias entrecruzadas: a dos conceitos, a das práticas e a das instituições, tentando abranger um fenômeno global que não se identifica nem ao mito da ciência pura, nem à análise exclusiva dos processos sociais.

Não pode, portanto, se prender a uma visão internalista, visto que as contribuições da ciência acarretam transformações econômicas e sociais. Nesta abordagem, explicita-se a contribuição da sociologia das ciências que auxilia a história da ciência, ao descrever a vida de um laboratório, de um homem, de uma disciplina, de uma comunidade, possibilitando compreender o sentido de um processo social, integrando as ciências a um processo social global, do qual elas são uma parte, um produto e, às vezes, um obstáculo. Porém, a descrição não é suficiente; é necessário entender o interesse dos procedimentos científicos pelo conhecimento da verdade. Salomon-Bayet afirma ser uma trivialidade, desde Bachelard, dizer que os manuais científicos foram escritos em nome de uma verdade que se pretende situada no presente intemporal um tempo que não existe.

Mas é importante que isto tenha sido dito e não seja esquecido; pois hoje assistimos ao fenômeno contrário ao destes manuais, ao considerar, exclusivamente, os interesses e negociações entre as forças sociais, onde verdade é 
igual à força, não no sentido de força demonstrativa de uma verdade, nem de eficácia em função de sua pertinência, mas no sentido de força dos autores mobilizados no combate pelo reconhecimento.

Salomon-Bayet considera importante a análise do papel das instituições no desenvolvimento da ciência. Por exemplo, ao ser criado o Instituto Pasteur, Pasteur deveria escolher entre unir-se à universidade ou ficar independente. Optou por ficar independente. A importância da investigação da instituição científica deve-se ao fato de permitir compreender a constituição de um espaço consagrado a uma função que abre um domínio e que permite, simultaneamente, transmitir a ciência que está sendo produzida, além de acolher a que ainda não foi feita. A história das ciências não poderia se fazer apenas a partir da vida dos sábios, nem exclusivamente da genealogia das descobertas. Ela deve se interessar também pelas relações entre o pensamento e a cultura, a época, o meio, o país - laços considerados, por muitos, indissociáveis. Daí sua proposta de uma história multidisciplinar, para a qual contribuiriam especialistas de várias disciplinas (bioquímica, história da ciência, sociologia, antropologia etc.), assumindo, todos, o mesmo objeto.

O objeto da história das ciências não se confunde com a ciência nem com o objeto da ciência: a história das ciências não é uma ciência, e seu objeto não é um objeto científico (Salomon-Bayet, 1986). A história das ciências afirma, de outro modo, aquilo que o artigo, a experiência, o tratado, a controvérsia afirmam no cotidiano do laboratório, das academias e da publicação. $\mathrm{O}$ artigo, o tratado, a experiência e a controvérsia fazem afirmações diferentes daquelas feitas pelo discurso político e pela argumentação do especialista. Quais seriam, então, as redes múltiplas que permitem delimitar uma verdade? Pois a própria ciência joga o jogo dos possíveis: há possíveis mais possíveis do que outros. Neste caso, a necessidade não passa da probabilidade mais forte, visto que são múltiplas as formas de dizer de outro modo. O objeto da história das ciências é um objeto, por definição, possível. No cruzamento da ciência - considerada o lugar da verdade - com a história e da ciência com a filosofia, surge um objeto possível, provável, com regras próprias de transformação.

Como toda história, a história da ciência deverá ser crítica, praticando um método que permita dar conta deste objeto, através da invenção, do exame, da reunião dos textos, dos documentos, dos fatos que configurarão um problema. Ela não pode se contentar em preparar anais, mas deve buscar um sentido, uma razão para o encadeamento dos fatos e dos conceitos, para a transformação das 
mentalidades. Um conhecimento do passado, segundo Salomon-Bayet, nos mostra aquilo que somos e em que nos transformamos, a partir de analogias que não são nem repetição, nem identidade de termos, mas identidade de relações e familiaridades de uma configuração de um saber ou de uma seqüência histórica tratados como um mapa. Em história da ciência, o mapa refere-se à topografia dos fatos, dos conceitos e seus entrecruzamentos.

A hipótese de Salomon-Bayet é que, na história das ciências da vida, Pasteur e seus trabalhos provocaram a primeira revolução teórica - com a teoria dos germes à qual se associa a técnica de atenuação dos vírus - e prática - com a medicalização da sociedade, através da legislação da saúde pública. Trata-se, portanto, de uma mudança na concepção e prática científicas e nas concepções e práticas sociais ao mesmo tempo. Segundo a autora, as vias da mudança jamais são lineares, visto que abarcam a evolução dos conhecimentos e dos conceitos, que não é cumulativa, nem pode ser compreendida por aprofundamentos, mas pela pesquisa de vários aspectos: a instituição científica (laboratório, pesquisas, experimentação), as estruturas médicas (hospitais, ensino, práticas cirúrgicas, higienistas e preventivas), as decisões administrativas e políticas e as mentalidades da saúde pública. Isto porque as disciplinas concernentes à microbiologia remetem, de um modo complexo, a estes elementos constituidores da pastorização da medicina.

Portanto, a pastorização da medicina não se define do mesmo modo que as revoluções científicas, conforme as compreende Kuhn (1982), isto é, revoluções no domínio das ciências físicas, matemáticas e astronômicas. O domínio da biologia e da medicina não tem uma estrutura tão evidente; menos ainda a microbiologia que é, na origem, simultaneamente, arte e ciência. Ademais, há muito poucas teorias unitárias nas ciências da vida, o que torna difícil a utilização do conceito de ruptura como substituição de uma teoria científica por outra, respondendo a uma crise.

De acordo com Salomon-Bayet (1986), a análise das crises do pensamento remete, necessariamente, à questão das dificuldades de uma teoria e da reorganização do saber no tempo. Seja o tempo considerado muito curto para a substituição lógica do sistema de saber precedente, caso em que não obedece ao mesmo ritmo de produção de pensamento até então observado; seja o tempo considerado apenas um pouco mais longo para o desaparecimento físico e intelectual da geração anterior, assim definida devido à adesão à ciência perecida.

Sua proposta é a de uma história que reúna a idéia de radicalismo - transformação da essência dos conceitos e das práticas científicas - e a revolução 
do tempo. Pensar a revolução pastoriana implica, então, pensar um objeto complexo, onde se entrecruzam química, biologia, medicina num tempo real que não se confunde com a data de uma descoberta pontual. É um tempo longo em que o enfoque teórico, os empréstimos e os deslocamentos conceituais e técnicos de uma disciplina, as localizações institucionais, as aquisições pontuais e as demonstrações e influências devem ser estudados de um ponto de vista crítico. Nesta perspectiva, a imagem que a história das ciências tem de revolução deve ser retocada quando o historiador se interroga sobre os mecanismos de introdução e difusão das teorias ou das novas verdades. Contudo, o pressuposto da radical novidade continua presente.

\section{HistÓRIA DO CAMPO DO POSSÍVEL SEGUNDO JACOB}

A Lógica da Vida (Jacob, 1983) pesquisa a história das ciências da vida em sua relação com a produção de verdade, situando toda a história da biologia entre o estremecimento superficial da vida e o profundo silêncio de sua lógica. Trata-se de uma descrição que se propõe a procurar não só os fundamentos lógicos dos sistemas vivos e de suas variações, mas também um quadro das tarefas e dos enigmas, cada vez mais numerosos, enfrentados pelas ciências da vida. Sua análise consiste numa história da genética que enfoca a maneira pela qual o conceito de geração - de criação sempre renovada e que exige a intervenção de uma força externa - transforma-se na noção de reprodução, propriedade interna de todo sistema vivo; é a história de um objeto cada vez mais oculto.

François Jacob ${ }^{32}$ analisa a questão da hereditariedade com o objetivo de descrever as condições que, a partir do século XVI, permitiram o aparecimento sucessivo de estruturas que emergem na arquitetura do ser vivo, reveladas em camadas cada vez mais profundas. A explicitação de níveis, cada vez mais profundos, do ser vivo não resulta, segundo Jacob, assim como segundo Foucault (1977, 2002a), de um acúmulo de observações e experiências, mas expressa uma mudança mais radical, que diz respeito a uma transformação na própria natureza do saber, correspondente a uma nova modalidade de considerar os objetos. Jacob considera que a possibilidade de as ciências da vida enfocarem novos objetos deve-se mais a uma mudança na forma de olhar o vivo, de

\footnotetext{
32 Professor de genética da célula no Collège de France e chefe de equipe do Instituto Pasteur. Recebeu o prêmio Nobel de Fisiologia e Medicina de 1965, junto com André Lwoff e Jacques Monod, por seus trabalhos sobre a genética das bactérias e dos vírus.
} 
interrogá-lo, de formular questões a que a observação deveria responder, do que ao aparecimento de novas técnicas responsáveis pelo aperfeiçoamento do equipamento sensorial.

Neste sentido, mesmo quando um instrumento aumenta o poder dos sentidos, ele nada mais é do que a aplicação prática de uma concepção abstrata. Por exemplo, o microscópio: é a reutilização de teorias - não basta ver um corpo até então invisível para transformá-lo em objeto de estudo, pois, "para que um objeto seja acessível à análise, não basta aperceber-se dele” (Jacob, 1983: 22), é necessário que o pensamento possa utilizá-lo. As transformações que modificaram a concepção de natureza dos seres vivos, sua estrutura, sua permanência ao longo das gerações são, segundo Jacob, progressivas e têm uma historicidade própria. A melhor abordagem desta historicidade é a história das questões, ou seja, das diversas configurações da interrogação sobre a natureza que abandona, inteiramente, o pressuposto clássico da verdade intangivel e eterna.

A maior contribuição da metodologia científica deve-se, em sua opinião, ao fato de ter ajudado na destruição da idéia de uma verdade teleológica deste tipo. O importante são as questões, não as respostas; do mesmo modo que a epistemologia francesa, Jacob considera essencial o estudo das diversas maneiras pelas quais as questões foram formuladas. Pois as respostas, ainda que parciais, são finalizações da elaboração científica da verdade, e, através delas, não conseguimos traçar o processo das produções científicas.

Como as outras ciências da natureza, a biologia perdeu, hoje, muitas das suas ilusões. Não procura mais a verdade. Constrói a sua, fazendo a realidade aparecer como um equilíbrio sempre instável. A história da ciência que objetiva os seres vivos mostra a existência de uma sucessão de oscilações, de um movimento pendular entre o contínuo e o descontínuo nos seres vivos, entre a estrutura e a função do vivo, entre a identidade dos fenômenos e a diversidade dos seres. É deste vaivém que, pouco a pouco, emerge a arquitetura do vivo em camadas cada vez mais profundas.

É deste processo de oscilações que resulta a noção de que no mundo vivo, como fora dele, trata-se de explicar o visível complexo pelo invisível simples. Nos seres vivos, como nas coisas, trata-se de um invisível de camadas superpostas, formando séries de organizações encaixadas umas nas outras como bonecas russas. Atrás de cada uma, esconde-se uma outra e, para além de cada estrutura acessível à análise, acaba se revelando uma nova estrutura, de ordem superior, que integra a primeira e lhe confere suas propriedades. Só se chega a esta ao se 
destruir aquela, decompondo o espaço do organismo para recompô-lo segundo outras leis. A cada nível de organização evidenciado corresponde uma nova maneira de abordar a formação dos seres vivos.

$\mathrm{Na}$ esteira de Foucault, Jacob afirma que as questões formuladas pelas ciências da vida sobre a vida e o ser humano devem ser analisadas a partir das diversas formas de relação entre a visibilidade, o olhar, e o conhecimento, isto é, a maneira de olhar e seu objeto, ou ainda, a partir dos diferentes modos pelos quais se enfoca a verdade. Jacob mostra que o conceito de verdade, enquanto objeto de revelação resultante de uma concepção do conhecimento como imagem exata de uma realidade dada que seria uma verdade última, é um tipo de questionamento que foi remanejado durante quatro séculos; mas "há muito tempo os cientistas renunciaram à idéia de uma verdade última e intangível, imagem exata de uma 'realidade' que estaria a postos apenas esperando o momento de ser revelada” (Jacob, 1983: 7). O conceito de verdade revelada é substituído pelo de verdade produzida, parcial e provisória. Para Jacob, nada causa mais destruição do que a obsessão de uma verdade absoluta.

Contudo, ao longo da história das ciências da vida, observa Jacob, o conflito entre estas duas concepções de verdade manifesta-se, periodicamente, nas formas de considerar a vida e o ser humano. A luta entre o universal e o local, entre o eterno e o provisório sempre reaparece em polêmicas, como, por exemplo, o debate entre os partidários da criação e os da evolução. Os primeiros encontram, no mais íntimo detalhe da natureza, o sinal que prova, infalivelmente, a verdade que eles não imaginam poder deixar de subscrever. Os partidários da evolução procuram, incansavelmente, nesta mesma natureza, traços de acontecimentos que, freqüentemente, não foram abandonados, com o objetivo de reconstruir aquilo que pretendem ser uma teoria em evolução, e não um mito.

Existem, para o biólogo, de acordo com Jacob, duas formas de posicionarse quanto à história de sua ciência. A primeira busca, na sucessão das idéias, o fio condutor que guiou o pensamento até as teorias vigentes na atualidade, fazendo uma extrapolação do presente para o passado, traçando uma história dos predecessores, rejeitada pela epistemologia. Escolhe-se o predecessor da hipótese em curso, depois o predecessor do predecessor, e assim por diante. Neste procedimento, as idéias adquirem independência, sendo compreendidas como tendo um comportamento semelhante ao dos seres vivos - nascem, crescem e morrem. Haveria, assim, uma evolução das idéias, como a evolução de seres, submetida, às vezes, a uma seleção natural baseada num critério de interpretação teórica. 
De acordo com esta abordagem, a geração espontânea, por exemplo, começaria a ser abalada com as experiências de Francisco Redi (1626-1698), perderia mais terreno com Spallanzani (1729-1799), desapareceria, definitivamente, com Pasteur (1822-1895). Seu problema é não explicar porque Pasteur repete, mesmo que aperfeiçoando, os trabalhos de Spallanzani para tirar as mesmas conclusões, nem porque Needham (1713-1781) faz, exatamente, a mesma coisa que Spallanzani e chega a resultados opostos. A outra maneira de posicionar-se, privilegiada por Jacob, é pelo viés de uma história das ciências biomédicas que fornece elementos para uma investigação da maneira pela qual os objetos tornaram-se acessíveis à análise, permitindo que novos domínios se constituíssem como ciência.

A possibilidade de analisar novos objetos foi, provavelmente, a responsável pela transformação do estudo dos seres vivos. Isto nem sempre foi conseqüência do aparecimento de uma técnica nova e responsável pelo aumento do equipamento sensorial; foi, mais, o resultado de uma mudança na maneira de olhar o organismo, de interrogá-lo, de formular as questões a que a observação deve responder. De fato, freqüentemente, se trata de uma simples mudança de enfoque que faz desaparecer um obstáculo, que ilumina algum aspecto de um objeto, alguma relação até então invisível (Jacob, 1983). Para tanto, é necessário precisar a natureza dos objetos, a atitude dos que os estudam, sua maneira de observá-los, seus obstáculos, através de uma análise conceitual. A importância do conceito será, neste caso, medida por seu valor operatório, pelo papel que desempenha ao dirigir a observação e a experiência.

Esta análise desprestigia a noção de uma filiação linear de idéias que se engendram umas às outras. Ela afirma a existência de um domínio que o pensamento se empenha em explorar, instaurando uma ordem para constituir relações abstratas de acordo não somente com as observações e as técnicas, mas também com as práticas, os valores e as interpretações da época. Daí a importância, nesta história, das idéias repudiadas e dos obstáculos, como na epistemologia francesa. Não se trata mais de reencontrar o caminho privilegiado das idéias, de retraçar a marcha de um progresso em direção ao que hoje aparece como a solução, de utilizar os valores racionais, hoje em vigor, para interpretar o passado e nele procurar a prefiguração do presente. Trata-se, ao contrário, de demarcar as etapas do saber, de precisar suas transformações, de revelar as condições que permitem que os objetos e as interpretações entrem no campo do possível. 
Cada época caracteriza-se pelo campo do possível, que é definido não somente pelas teorias ou crenças em curso, mas pela própria natureza dos objetos acessíveis à análise, pelo equipamento para estudá-los e pela maneira de observá-los e de falar sobre eles. É somente nesta zona que a lógica pode evoluir. É no interior dos limites assim fixados que as idéias se movem, se testam, se opõem. Dentre todos os enunciados possíveis, trata-se então de escolher o que melhor integra os resultados da análise. Desta forma, Jacob rejeita o estudo da trajetória das idéias, abstendo-se de fazer um recuo histórico que traçaria a marcha de um progresso, utilizando os valores racionais, atualmente vigentes, para interpretar o passado, e nele procurar a prefiguração do presente. Ao contrário, ele tenta demarcar as diversas etapas do saber, precisar suas transformações e revelar as condições que permitem que os objetos e as interpretações entrem no campo do possível, dando origem a relações e a objetos novos, mudando a ordem em vigor.

Neste sentido, é que afirma que a geração espontânea não é mais, então, uma operação quase linear que conduz de Redi a Pasteur, passando por Spallanzani. O desaparecimento da noção de geração espontânea é produto de meados do século XIX, quando se introduz o conceito de vida no conhecimento dos seres vivos, o qual só pode surgir ao se delimitar a espécie, rompendo a continuidade entre o orgânico e o inorgânico. Afinal, devido à sua rigidez e ao seu dogmatismo, pela obstinação em só considerar a fixidez das espécies, Lineu (1707-1778) e Cuvier contribuíram tanto quanto Redi e Spallanzani, com suas experiências, para eliminar a geração espontânea. $\mathrm{O}$ erro é constitutivo do campo do possível em toda a extensão.

\section{BIOLOGIA E HEREDITARIEDADE}

É nesta perspectiva que Jacob traça uma história da biologia desde seus começos até o século XX. É com este ponto de vista que esclarece que, em meados do século XIX, há uma mudança na prática da biologia, e que, em menos de vinte anos, aparecem a teoria celular em sua forma definitiva, o estudo da hereditariedade, o estudo das fermentações e a síntese total dos primeiros compostos orgânicos. Com Virchow (1821-1902), Darwin (1809-1882), Claude Bernard (1813-1878), Mendel (1822-1884), Pasteur (1822-1895) e Berthelot (1827-1907), definem-se os conceitos, os métodos, os objetos de estudo que estão na origem da biologia moderna, pois a atitude, como afirma Jacob, adotada nesse momento, praticamente, não mudará durante o século XX e início do século XXI. Até então reduzida à observação, a biologia torna-se uma ciência experimental. 
Na primeira metade do século XIX, a organização constituía o dado fundamental para a observação e a caracterização dos seres vivos. Na segunda metade do século, a organização deixa de constituir um ponto de partida para o conhecimento dos seres, tornando-se um entre outros objetos de conhecimento. Passa a ser preciso investigar, em todos os níveis, aquilo em que a organização se funda, como é estabelecida, quais são as leis que regem sua formação e seu funcionamento. A partir de então, o que se interroga não é mais a vida concebida como força oculta irredutivel e inacessível; interroga-se aquilo em que a vida se decompõe, sua história, sua origem, a causalidade, o acaso, o funcionamento.

A biologia divide-se, assim, em dois ramos diferentes: o que continua a se ocupar do organismo em sua totalidade, como unidade intangível, como elemento de uma população ou uma espécie, funcionando com os conceitos da história natural, e aquele que procura reduzir o organismo a seus elementos constituintes - como exige a fisiologia. Toda a natureza é compreendida como tendo uma história própria, mas uma história em que os seres prolongam as coisas e o homem está em continuidade com o animal num mundo contingente. É assim, afirma Jacob, que se procura restabelecer a relação de separação, traçada no final do século XVIII, entre o orgânico e o inorgânico. A partir dessa época, da matéria inanimada ao vivo não há uma diferença de natureza, mas de complexidade. A célula está para a molécula como a molécula está para o átomo - um nível superior de integração. Esta biologia analisa as reações químicas, estuda células, desencadeia fenômenos. Se o organismo ainda é concebido como um todo, é porque a regulação das reações, a coordenação das células, a integração dos fenômenos permitem uma síntese.

No início do século XX, delimita-se uma série de novos objetos de estudo. Organiza-se, em torno de cada um deles, um domínio específico da biologia, fragmentando-a progressivamente. A palavra biologia acaba cobrindo ciências diversas que se distinguem por seu material e sua linguagem. Dentre elas, a bioquímica e a genética remodelam, inteiramente, a concepção de organismo, mudando, completamente, a representação que se faz dos organismos. A bioquímica, que trabalha com extratos, estuda os elementos constituintes dos seres vivos e as reações que neles se produzem, remetendo a estrutura dos seres e suas propriedades à rede das reações químicas e aos desempenhos de algumas espécies moleculares. A genética, ao contrário, interroga populações de organismos para analisar a hereditariedade; atribui a produção do idêntico e o aparecimento do novo às qualidades de uma estrutura nova, existente no 
núcleo da célula, onde se aloja a memória da hereditariedade, que comanda todos os níveis, para determinar os caracteres do organismo e suas atividades: dirige o desenvolvimento do embrião, decide a organização do adulto, de suas formas, de seus atributos.

Com a bioquímica e a genética, os seres vivos não se ordenam mais em profundidade, unicamente pela articulação dos órgãos e das funções, não se enrolam mais em torno de um foco de vida de onde se irradia a organização. As qualidades dos vivos baseiam-se, então, em duas entidades novas: o que os bioquímicos chamam de proteína e os geneticistas, de gene. A proteína é a unidade de execução química que realiza as reações e dá aos corpos vivos sua estrutura; o gene é a unidade de hereditariedade que rege, ao mesmo tempo, a representação de uma função e sua variação. O gene comanda; a proteína realiza. As duas ciências conhecem o objeto da análise futura, explica Jacob, porém, não têm, até meados do século XX, meios para realizá-la.

De acordo com Jacob, no final do século XIX e até a primeira metade do XX, desaparece a antiga forma do vitalismo que ele afirma ter sido necessário para a constituição da biologia, no início do século XIX - afirmação com a qual concordam Canguilhem e Foucault -, e surgem novas formas possíveis de conhecimento no campo biológico.

Diante do desenvolvimento da ciência experimental, da genética, da bioquímica, não se pode mais, a não ser através do misticismo, invocar seriamente um princípio de origem desconhecida, um X que escaparia por sua própria essência às leis da física, para explicar os seres vivos e suas propriedades. Se a física parece não poder explicar o conjunto dos fenômenos da vida, não é mais devido a uma força exclusiva do mundo vivo, impossível de ser conhecida. É devido a limites inerentes à observação e à análise, à complexidade dos seres vivos em relação à matéria. (...) Portanto, não se trata mais de recorrer a uma força misteriosa para justificar a origem, as propriedades, o comportamento dos seres vivos. Trata-se de saber se as leis já encontradas na análise da matéria bastam ou se é preciso procurar novas. Para se constituir como ciência, a biologia teve que se separar radicalmente da física e da química. Em meados do século XX, para prosseguir a análise da estrutura dos seres vivos e de seu funcionamento, teve que se associar intimamente a elas. Desta união nascerá a biologia molecular. (Jacob, 1983: 248-249)

Para a elaboração da história da hereditariedade, Jacob analisa estes conteúdos, partindo de pressupostos explicitados pela epistemologia e pela arqueologia do olhar: uma análise histórica descontínua, conceitual, que se 
situa no nível das condições de possibilidade das transformações na própria natureza do saber. Em sua opinião, existem, para o biólogo, duas formas de enfocar a história de sua ciência: a que a concebe como a sucessão das idéias, e esta ele rejeita, e aquela que investiga como os objetos tornaram-se acessíveis à análise, permitindo que novos domínios se constituíssem como ciência.

\section{Genealogia de Latour}

Um ponto comum às histórias tratadas até aqui é a perspectiva de que a conjunção da verdade com a objetividade nas ciências deve ser criticada. Tal perspectiva se esclarece ainda mais se a elas acrescentam-se algumas noções das genealogias propostas por Foucault e Latour, sobretudo em seu caráter de análise das relações de forças como constitutivas dos discursos científicos.

A análise de Latour propõe uma nova concepção de objeto - "quaseobjeto” - que não apresenta os contornos clássicos, pois não se caracteriza pela necessidade de exterioridade natural. Ao deslocar as questões da verdade e da objetividade científica - tão caras à tradição filosófica ocidental - para a noção de saberes indissociáveis das relações de poder, das lutas de forças singulares e específicas, Latour aproxima-se da perspectiva foucaultiana de história dos enunciados e dos poderes neles investidos. Sua abordagem parte da afirmação do caráter arbitrário da Razão - filosófica e científica - instituída com a sistematização de uma lógica dicotômica, segundo a qual se estabeleceram oposições como relações de razão e relações de força, verdade e erro, ciência e sociedade, objetividade e subjetividade, sujeito e objeto, sujeito e natureza, ciências duras e ciências sociais e humanas.

Deste ponto de vista, as visões tradicionais de ciência instauradas na modernidade são abandonadas por se fundarem no mito da Razão, cujas dicotomias precisam ser ultrapassadas quando se pretende elucidar os processos de produção científica. As explicações, segundo as quais saber e poder são colocados em pólos opostos e dispostos de acordo com a hierarquia dual dos valores e onde se sobrepõem as noções de verdade, ciência e objetividade, de um lado, e erro, sociedade, política e subjetividade, do outro, tornam-se opacas.

A rejeição de todos os binômios - principalmente os metafísicos (como interioridade e exterioridade, cultura e natureza, bem como os já mencionados) - normalmente assumidos quando fazemos história das ciências ou dos saberes, conduz Latour ao projeto de uma genealogia da Razão: recuar, através 
da filosofia, ao momento em que se separaram e hierarquizaram relações de razão e relações de forças, momento em que nos enganamos, uma vez que, para ele, estes são inseparáveis, ou melhor, uma vez que, conforme afirma Foucault, há uma relação de imanência entre os saberes e os poderes.

$\mathrm{Na}$ genealogia de Latour, desaparece o conceito de objetividade como qualidade daquilo que é objetivo - no sentido de correspondência a um objeto externo natural ou produzido e que diz respeito a tudo aquilo que é apreendido pelo conhecimento (manipulável ou manufaturável, perceptível pelos sentidos etc.), e considerado distinto do sujeito do conhecimento. Este conceito é elidido em função de um estudo do papel desempenhado pelo objeto, considerado, então, como agente, como força. Segundo Latour, o objeto é uma noção que deve ser entendida através do conceito de ator numa rede móvel de inter-relações de atores humanos e não-humanos, sábios e nãosábios. Deste modo, a divisão entre um mundo natural e um mundo social perde a eficácia explicativa; ela não interessa mais para a análise da produção de conhecimentos objetivos e verdadeiros.

Em Les Microbes: guere et paix (Latour, 1984), esta idéia é explicitada por uma reinterpretação da história da revolução pastoriana em que o micróbio de Pasteur e os atores humanos são forças irredutiveis, desempenhando papéis simétricos e específicos nos jogos das relações de forças. São quase-objetos, não objetos no sentido de entidades fixas; são fluxos que circulam numa rede de relações de forças, atores que não têm essência ou ontologia. Tratase de um conceito que recobre os humanos e os não-humanos naturais ou sociais, por meio de uma listagem de ações, de respostas escritas e testes. As bactérias, as enzimas, os elementos, as partículas que saem dos laboratórios, são definidos, como já dissemos, por operações que geram inscrições a eles associados. O número, a natureza, os poderes dos atores não são permanentes, eles são transformados por traduções e pelo estado da rede, ou melhor, pelas inter-relações dos porta-vozes que a constituem. Sua realidade depende do que dizem os enunciados, a não ser quando se manifesta uma resistência, quer dizer, quando os efeitos de uma ação entram em conflito com associações já estabelecidas.

O primeiro micróbio que nos propõe Latour age e dispõe de todas as qualidades normalmente atribuídas aos humanos: tem necessidades e afinidades. É um aliado que faz escolhas e que confere a Pasteur toda a sua força de ser autônomo. Este primeiro micróbio é descoberto e modificado por Pasteur. É preciso lembrar que, antes de ser colocado em cultura bacteriana, sua única 
forma de existência é metafísica. É um objeto construído, cujo nome não representa um ser, mas um novo regime dos discursos e das ações. Seu poder advém de uma forma naturalizada que permite designar os efeitos produzidos pela mobilização dos materiais e dos instrumentos, a aquisição do saber-fazer, bem como as discussões entre os humanos. A dificuldade desta idéia consiste na redução do micróbio às ações dos homens que acionam o processo de produção científica.

Para analisá-lo, Latour propõe um manual de filosofia política baseado no pensamento da multiplicidade dos estados de força, ao invés da busca de unidade. A questão o que é força, o que é estado de força, então, persiste, pois, para ele, as diversas definições encontradas em ciências e em filosofia não são suficientes. Isto porque, a seu ver, a matéria da força é variável e os estados das forças são diversos e sempre irredutiveis entre si, conforme assinalado. Os princípios de "irredução" e o de simetria das forças - este último tomado da antropologia - sugerem a necessidade de tratar todos os atores da mesma maneira, sublinhando a relevância do procedimento genealógico como pano de fundo dos estudos de sociologia da ciência, desenvolvidos em Give me a Laboratory and I Will Raise the World (Latour, 1983), bem como nas pesquisas subseqüentes.

Em Nietzsche, a Genealogia e a História (1982), Foucault explicita o procedimento genealógico, conforme mostramos no item "Forças e ângulo dos deslocamentos segundo Latour" (cap. 2). A proposta de Latour reúne a própria genealogia e o modelo político de batalha de Tolstoi: investigar tanto as grandes multidões, quanto os personagens particulares que dão ordens às massas - ordens que são mal compreendidas, mal transmitidas, traídas, levando a deslocamentos de regimentos, e que, em troca, obtêm informações deformadas, tardias e traídas. Enquanto batalha, a ciência deve ser entendida como uma multidão de aliados heterogêneos que compõem a forma dos objetos ditos científicos. Convém ressaltar que, nessa multidão, incluem-se tropas sábias (cientistas e doentes, por exemplo) e não-sábias (micróbios e artefatos, por exemplo), tropas humanas e não-humanas, ou seja, todos os atores da revolução. Assim sendo, como separar atores humanos, de um lado, e objetos respeitáveis, lá fora, no mundo, de outro?

O princípio de simetria (Latour, 1984, 1991) é que permite tais contestações. O conceito de quase-objeto substitui a noção clássica de objeto. Pode ser reconhecido nas constantes mantidas nos deslocamentos espaciais e temporais, ou seja, nas constantes presentes nas transformações. No caso do princípio de 
simetria entre humanos e não-humanos, mantêm-se séries de competências e de propriedades que os agentes são capazes de apontar uns em relação aos outros, eliminando as hierarquias, as assimetrias ontológicas, a fim de superar as oposições citadas.

Para Latour, a ilusão da modernidade era acreditar que quanto mais evoluíssemos, mais distante ficaria a subjetividade da objetividade, criando, assim, um futuro radicalmente diferente do passado. Para ele, isto nunca aconteceria. A objetividade e a subjetividade não são opostas, elas crescem irreversivelmente juntas. $\mathrm{O}$ desafio, para a filosofia, seria conceber instituições políticas que pudessem absorver a idéia de que artefatos não são apenas coisas, mas agentes culturais que medeiam nossas ações. Deste modo, compreende-se sua afirmação, em Science in Action (Latour, 1987), de que o destino dos fatos e das máquinas depende de longas cadeias de atores que os transformam, sendo suas qualidades a conseqüência e não a causa desta ação coletiva.

A pesquisa sobre a revolução pastoriana é uma explicitação dos princípios norteadores de todo o seu trabalho posterior. Aí, a concepção tradicional de ciência pastoriana e da luta, travada por Pasteur contra os micróbios, sofre uma imensa reviravolta com respeito às histórias fundadas na afirmação da objetividade do tipo adequatio rei et intellectus e suas variantes. $\mathrm{O}$ exemplo escolhido por Latour - revolução pastoriana - é considerado por ele mesmo o mais afastado possível do que deseja mostrar, uma vez que:1) ocorreu no momento de exaltação da ciência; 2) sua utilidade pública é tida como indubitável em termos das novidades introduzidas na medicina; 3) sua inovação científica ou técnica apresenta a maior proximidade possível entre a pesquisa básica e as aplicações mediatas ou imediatas; 4) parece haver, finalmente, aplicação dos métodos à arte médica; 5) apresenta provas objetivas de sua produção científica etc.

Em toda a sua obra, a proposta de Latour é fazer esta redistribuição, através de sua concepção de objetividade, estabelecida a partir do princípio de simetria ampliada, no sentido de que todos os elementos que estão em jogo compõem, igualmente, o mundo, na qualidade de atores, de agentes, sejam eles humanos ou não-humanos, sábios ou não-sábios. Ao propor um método que tenta recompor as forças, Latour tenta não reduzi-las umas às outras, nem hierarquizá-las a priori (razão superior, poder e sociedade inferiores). Segundo ele, devemos pensar com o princípio de irredução e de projeção das forças envolvidas que nos permite seguir os múltiplos e imprevisíveis contornos do mundo, composto de atores, provas, deslocamentos de forças, vontades e interesses, comunicação, traduções, 
quase-objetos. Seu método de composição tem, como ponto de partida, aquilo que cada ator diz dos outros atores humanos e não-humanos.

A seu ver, no pastorianismo, por exemplo, os adjetivos e os enunciados, utilizados pelos atores para qualificar os micróbios, é que os definem como atores: "solidariedade", "potência", "comensal", ou, como mostra um texto de 1894: "Acabamos de esboçar em linhas gerais, o modo pelo qual os micróbios patogênicos evoluem na sociedade (...). A sociedade só pode existir, só pode viver e substituir graças à intervenção constante de micróbios, grandes provedores de morte, mas também dispensário de matéria" (Latour, 1984: 44). Assim, o estudo da revolução pastoriana evidencia a criação de novas fontes de poder e de legitimidade, irredutíveis àquelas que codificavam até então o espaço dito político; evidencia, ainda, a função dos micróbios de renovar, inteiramente, o jogo político com forças novas.

É nesta perspectiva, que devemos entender as afirmações de Latour, em 1992, quando proclama que, para determinar se um enunciado - que define o grau de eficácia e perfeição de um mecanismo - é objetivo ou subjetivo, não adianta buscar respostas em suas qualidades intrínsecas, mas reconstruir, historicamente, o conjunto das transformações que sofre, mais tarde, nas mãos dos outros. Dito de outro modo, é a natureza da força coercitiva dos enunciados que convence a validade de sua própria posição. Se considerarmos esta abordagem, o que está em jogo é o familiar problema da legitimação científica - seus métodos, seu objeto.

Para ele, a análise dos enunciados, tal como colocada por Foucault, é bastante importante. Na opinião de Latour, a relevância da análise foucaultiana está na concepção da relação de imanência entre saber e poder, de um lado, e da relação entre sociedade e discurso, de outro. Por esta razão, de acordo com Latour, as duas maiores contribuições de Foucault são a análise dos discursos, elaborada em As Palavras e as Coisas e em Arqueologia do Saber, assim como a do regime de distribuição dos enunciados em Vigiar e Punir. Latour atribui tal importância às investigações de Foucault, devido ao impasse do neokantismo nelas apontado: como se assegurar, passo a passo, de que as mesmas estruturas se encontram em toda parte, que as mesmas categorias formam todos os conhecimentos produzidos num dado momento? E, ainda, devido à substituição das categorias, que se impõem para todos, por uma distribuição dos enunciados possíveis, perfeitamente localizáveis e observáveis.

É o regime do discurso, e não o discurso em si mesmo, que possui uma estrutura e uma organização que tornam possíveis certos enunciados, certos 
encadeamentos e interditam outros. A transcendência buscada está aí, nesta economia dos enunciados, em sua rarefação e sua proliferação organizadas: certas coisas podem ser ditas e outras não, certas deduções são admitidas e outras proibidas. E este regime se estabiliza em vastas configurações que fazem seu tempo e fabricam sua história. Segundo Latour, esta solução pode, em princípio, ser estudada empiricamente. Porém, na prática, evidenciar tais regimes não é fácil e a arbitrariedade do analista é enorme. Mas, sobretudo, falta explicar o que produz estes enunciados e a maneira pela qual são produzidos.

A restrição ao trabalho de Foucault deve-se, primeiramente, ao fato de não tratar as chamadas ciências duras - exceção feita às ligadas à medicina - e, em segundo lugar, à concepção de poder que tende a sobrepujar o saber, através de uma análise bastante reducionista. Neste sentido, o maior problema apontado é a tentativa de redefinição do poder. Da forma como foi feita, afirma Latour, a dificuldade está em utilizá-la para os atores não-humanos das ciências duras, ou seja, como utilizá-la para descrevê-los. Em sua opinião, Vigiar e Punir é um campo fascinante para estudar a disseminação do poder; porém, ele só levanta o problema, não o resolve. Pelo fato de considerar o poder algo que se dissemina e não uma coisa inerte, não se sabe se suas análises resistiriam aos testes da química, da física ou da teoria da relatividade. É sob esta ótica que Latour coloca sob suspeita a abordagem foucaultiana.

Ao desconsiderar a delimitação do objeto das pesquisas propostas por Foucault, sobretudo no que tange à especificidade dos saberes analisados, os saberes sobre o homem, Latour termina por buscar generalizações incompatíveis com um cuidado metodológico de grande relevância na crítica foucaultiana que se funda na noção de história regional. A cada região de saber, deve corresponder um tipo específico de abordagem que não pode ser confundido com regras gerais de método aplicável a todas as análises. Ademais, se esquece de que as prescrições metodológicas são estabelecidas juntamente com os documentos encontrados; o método e seus pressupostos não são nunca dados a priori.

Contudo, Latour reconhece que Foucault rompe com todas as respostas imaginadas antes dele, uma vez que considera que o enunciado é indissociável das técnicas e de todos os dispositivos, materiais e institucionais, pelos quais os atores humanos se definem entre si. Apesar das restrições, para Latour, a lição da análise foucaultiana dos discursos é importante: um enunciado se produz ao mesmo tempo que o objeto que o qualifica, e sua produção é instrumentalizada em toda uma série de operações que fazem falar o objeto 
de conhecimento e obrigam a reconhecer que ele é, realmente, aquilo que o enunciado diz que ele é.

\section{OBJETO E CIÊNCIA}

Cabe, antes de mais nada, perguntar como Michel Serres em Eclaircissements: entretiens avec Bruno Latour (1992): Como aconteceu de as ciências humanas ou sociais nunca falarem sobre o mundo, de tal modo que os grupos permanecessem suspensos no vazio? Como as ciências ditas duras deixam os homens de lado? E, ainda, por que nossos saberes se perpetuam hemiplégicos? Para Serres, fazê-los aprender a caminhar com os dois pés, a utilizar as duas mãos, parece ser um dos deveres da filosofia. Trata-se do elogio dos mestiços e das misturas que causam horror aos filósofos da pureza.

A idéia de que, em história das ciências, nenhuma explicação escapa à análise das relações de forças, leva-nos a repensar a crítica de Latour à visão de ciência como mito fundado numa cisão - relações de razão versus relações de forças, isto é, ciência versus sociedade - que precisa ser ultrapassada. Ao propor um método que tenta recompor as forças, sem reduzi-las nem hierarquizá-las, trava-se a luta contra a Razão, por vezes considerada a maior fonte de patologia e de mortalidade do século XX.

Latour apresenta o modelo político da batalha, inspirado em Tolstoi, que inclui uma multidão de aliados, estudando os ângulos dos deslocamentos tanto das grandes multidões envolvidas, quanto dos personagens particulares que dão ordens às massas. Ordens que são mal compreendidas, mal transmitidas, traídas, ocasionando movimentos de regimentos, e, em troca, fazendo com que se obtenham informações diferentes das originais. Para Latour, deste ponto de vista, a ciência deve ser estudada como uma multidão de aliados heterogêneos que compõem a forma dos objetos ditos científicos. Convém ressaltar que, nessa multidão, incluem-se tropas humanas e não-humanas, sábias e não-sábias.

Sua análise baseia-se na denúncia do caráter arbitrário da Razão dicotômica que institui tal cisão, a ela opondo o princípio da multiplicidade de forças, segundo o qual é necessário criar um princípio de projeção que permita seguir os múltiplos e imprevisíveis contornos do mundo. Para tanto, o projeto de uma genealogia nietzschiana parece ganhar cada vez mais sentido: recuar, através da filosofia, ao momento de origem em que se separaram saber e poder. Neste sentido, as noções de estado de natureza e de estado de sociedade são duas 
conseqüências simétricas da ação dos pesquisadores para alinhar humanos e não-humanos. Assim, resta perseguir, com o ponto de vista das irreduções, os atores, os deslocamentos por eles operados, as cadeias de traduções, as alianças, enfim, as forças.

A ênfase dada ao papel dos atores/agentes na proposta de definição da transdisciplinaridade, em detrimento de suas bases científicas na circulação dos discursos - é claro que nenhuma idéia se desloca sozinha! - parece ser fruto de um receio sociológico-reducionista das atuais estratégias de oposição que, apesar da proposta de um recurso à natureza enciclopédica, são empregadas para estudar o discurso científico, afirmando-se como crítica construtivista, e que terminam por explicar a natureza (derivada tanto das teorias, como dos fatos empíricos), através de uma análise de interesses e forças como determinantes de sua construção.

Entretanto, segundo Foucault, ao dirigir-se ao domínio do saber, não podemos nos restringir à descrição de disciplinas ou ciências, mas à descrição de positividades, o que abrange os documentos literários, filosóficos ou políticos, bem como as práticas (discursivas e não discursivas). Analisar as positividades é apontar as regras segundo as quais uma prática discursiva pode formar grupos de objetos, conjuntos de enunciações, jogos de conceitos, séries de escolhas teóricas. O objetivo de Foucault é estabelecer relações entre os saberes, considerados como possuindo uma positividade específica - a positividade do que foi, efetivamente, dito e deve ser aceito como tal -, para que, destas relações, surjam, em uma mesma época ou em épocas diferentes, compatibilidades e incompatibilidades que permitam individualizar formações discursivas e traçar as diversas configurações dos campos de saber. A articulação entre os saberes e as práticas é possível devido à relação de imanência entre os discursos e certos princípios de organização dos saberes que podem ser situados como elementos de um dispositivo essencialmente político.

A lição é geral: um enunciado se produz ao mesmo tempo que o objeto que o qualifica, e sua produção é instrumentalizada em toda uma série de operações que fazem falar o objeto de conhecimento e o obrigam a reconhecer que ele é, realmente, aquilo que o enunciado diz que ele é. Estamos, portanto, diante de várias séries entrecruzadas de elementos que constituem uma rede de práticas e conhecimentos, que devem ser lembrados ao pensarmos a interdisciplinaridade em saúde coletiva. Séries de relações lógicas e metodológicas, séries de relações de sujeitos e objetos. Atualmente, já não se fala mais objeto simplesmente; o objeto é recente e ainda carece de adjetivos: objeto fronteiriço, 
objeto híbrido, objeto-mundo, quase-objeto, objeto complexo. A esta atividade de adjetivação dos conteúdos das ciências da saúde corresponde uma reflexão sobre as formas de abordá-los. Tantos adjetivos dizem respeito ao esforço de lidar com um real esfacelado que se quer unidade, totalidade, com a garantia das especificidades que os constituem como objetos de pesquisa que precisam receber um novo tratamento.

A pesquisa biomédica, freqüentemente, combina uma forte auto-imagem da ciência fundamental com uma ligação com a prática médica igualmente forte. Ela é legitimada pela sua contribuição para a compreensão fundamental dos fenômenos da vida e para a solução de problemas práticos de detecção, cura e prevenção de doenças. Os estudiosos das práticas de laboratórios biomédicos esbarram em tais articulações, e, cada vez mais, as incluem em suas investigações. Terminam por deparar-se com a questão da gênese e desenvolvimento dos fatos científicos. Um fato científico pode ser concebido como uma regra produzida por um pensamento coletivo, isto é, por um grupo de pessoas ligadas por um estilo de pensamento comum que formula não só o conhecimento, considerado como garantido por um pensamento coletivo dado, mas também seu corpo de práticas: métodos e ferramentas usados no exame da evidência e critérios para julgar seus resultados.

A tradução da medicina para a pesquisa biomédica nem sempre apresenta unidade. A biologia depende das articulações bem-sucedidas com as demandas médicas, os interesses criadores dos políticos e dos capitalistas especuladores e dos industriais. Em suma, os pesquisadores e práticos biomédicos trabalham na interseção do 'bio', próprio do mundo das ciências, com o mundo médico composto por médicos, industriais, administradores da saúde e pacientes. As demandas da área médica e da indústria, muitas vezes, interagem com a pesquisa biomédica, e as traduções, com sua multiplicidade de direções, podem moldar tanto a pesquisa quanto as práticas médicas e industriais.

Um exemplo de Ilana Löwy (2002): os oncogenes (genes celulares considerados implicados na transformação maligna da célula) foram descritos, primeiramente, pelos oncologistas e foram vinculados à transformação das células pelos vírus oncogênicos. Depois, desenvolveram-se estudos dos oncogenes celulares - esta transição foi moldada por circunstâncias materiais, como a difusão da engenharia genética, além de outros acontecimentos, como o fracasso do Programa Vírus-Câncer do Instituto Nacional do Câncer, nos Estados Unidos, e a crescente importância das conexões entre os laboratórios biomédicos e as empresas de biotecnologia. 
A estabilização dos oncogenes como fenômenos biológicos e sua fusão nos diversos mundos sociais (biólogos moleculares, biólogos celulares, pesquisadores do câncer, oncologistas clínicos) estava vinculada à generalização de métodos padronizados de pesquisa em biologia molecular e de reagentes padronizados (investigações sobre o DNA, anticorpos dos monoclonos). Os grupos profissionais que se esforçam para manter a sua autonomia e o seu prestígio precisam ter o controle do acesso ao conhecimento padronizado e transmissível que lhes permite competir com a incerteza, mas, ao mesmo tempo, precisam assegurar-se de que seus métodos e habilidades não sejam reduzidos a rotinas das quais qualquer pessoa possa se apoderar. Tentam encontrar um ponto intermediário que lhes permita codificar os padrões de comportamento profissional, deixando-lhes espaço suficiente para o conhecimento especializado.

O termo objeto fronteiriço - que os lingüistas utilizam para exprimir o caráter indeterminável da linguagem natural - foi usado pelos sociólogos da ciência para descrever entidades que apresentam estruturas frágeis no uso comum e são fortemente estruturadas no uso local individual. Estes objetos facilitam interações heterogêneas entre mundos sociais distintos. Um objeto fronteiriço é constituído de um núcleo rígido - uma zona de acordo entre os grupos profissionais que interagem - e a partir de uma periferia difusa, indistinta, que é diferente para cada grupo. A transposição e assimilação de elementos de um estilo de pensamento diferente (geralmente mais prestigiado por um outro grupo) podem acarretar benefícios concretos para o grupo que assimila estes elementos de estilo.

Os objetos fronteiriços e as transposições e assimilações podem ser tomados como artifícios que possibilitam o desenvolvimento da interação entre mundos heterogêneos, permitindo a coordenação local das práticas e dos atores distintos que continuam ligados aos seus diferentes estilos de pensamento, coletivos, gerais. Fala-se que há coisas que são do domínio do coletivo e do domínio da natureza. A noção de objetos híbridos não faz esta disjuntiva.

Tomarei de Serres o exemplo do carro e seu proprietário deslocando-se no dia de um feriado oficial que se deve a uma data religiosa (domínio político e religioso). O carro percorre um espaço (domínio da natureza). O carro é uma máquina, um objeto técnico, que acentua a dominação humana, concorrendo para a vaidade de seu proprietário, regulando algumas relações psicológicas ou de grupos e conduzindo a uma antropologia (domínio da cultura). Com estes exemplos, vemos como é possível passar, sem ruptura, da ciência (a termodinâ- 
mica e a resistência dos materiais) à técnica e desta à sociologia, depois à história das religiões. Para Serres, as ciências são formações culturais entre outras, e o utensílio é, ao mesmo tempo, um objeto-mundo e um objeto-sociedade. Cada técnica transforma nossa relação com as coisas e, simultaneamente, as relações entre nós, pois assegura a publicidade das nações que a lançam. Contudo, os cientistas ignoram a cultura, e prendem-se à ordem das disciplinas estruturadas em termos de conteúdos e de instituições, de jogos organizados de ensino, de laboratórios e patrões, de revistas e editores.

Fala-se que há quase-objetos: com este enfoque, é preciso recompor as forças. O destino dos fatos e das máquinas está nas mãos de longas cadeias de atores que os transformam. Enfocados a partir do princípio de simetria (da irredução de uma força à outra), torna-se necessário identificar os vários estados de força: resistência, dominação, enfraquecimento, desdobramento, reforço etc. $\mathrm{O}$ que importa é observar as indecisões dos diferentes atores (por exemplo: Pasteur, os micróbios, os doentes, os medicamentos, as provas 'irrefutáveis', os médicos da Academia de Medicina, os reagentes, instrumentos e métodos no laboratório etc.), na composição exata da tecnologia científica. Dada a simetria, o que resta é aquilo que se conserva através das transformações, afinal nunca nos defrontamos com uma ciência, mas com uma gama de associações mais ou menos fortes ou fracas de humanos e não-humanos.

Na simetria entre humanos e não-humanos, natureza e sociedade, ciência e tecnologia há séries constantes de competências e de propriedades. A ilusão moderna de que a distância entre natureza e sociedade e entre subjetividade e objetividade aumentaria progressivamente está em descrédito. Objetividade e subjetividade sequer se opõem, pois surgiram juntas. Os artefatos não são mais coisas, são atores que intermedeiam nossas ações. O desafio é conceber instituições políticas que possam absorver a idéia de que todos estes objetos não são coisas apenas, são também agentes culturais. Deste modo, não podem ser concebidos como entidades fixas, mas como fluxos.

O problema é como lidar com todos estes objetos e criar um método para fazê-lo concretamente. A idéia de um saber enciclopédico, conforme proposto por Serres, no final do século XX, parece bastante interessante, pois pertence à ordem da sabedoria, onde não se perde a perspectiva da totalidade ativa do saber do mundo e da vida; ao tentar tudo incluir (ciências, mito, literatura), permite-nos pensar as circunstâncias da história: a morte, o amor, a alteridade, a violência, a dor, o mal. O grande obstáculo, justamente, reside nas divisões impostas nas instituições de ensino e pesquisa que cristalizaram o conhecimen- 
to em dicotomias e subdivisões das dicotomias, até as especialidades díspares e incomensuráveis, incomunicáveis. De fato, resta-nos, agora, reunir, recompor o mundo, misturar. Como fazê-lo? Eis aí o desafio.

Transportes, transferências, traduções serão necessários, a saber, todas as dificuldades, todos os obstáculos, todas as condições destes transportes de métodos, de práticas, de objetos, incluindo os micróbios, os artefatos, os quase-objetos, os objetos fronteiriços, os atores que permitem as passagens, mediando a comunicação alcançada, ou, ao contrário, aquelas que foram interceptadas e que a tornam difícil ou impossível.

A nova enciclopédia assume o papel paradoxal de acumulação máxima de todos os saberes e de todas as experiências, em que, evidentemente, as mediações se multiplicam e, ao mesmo tempo, se anulam. Para chegarmos à convivência destes dois pólos - acumulação máxima e supressão total - certamente, uma única resposta a todas as questões parece pouco provável. Os bons métodos são extraídos do problema a ser resolvido; as melhores soluções são locais, singulares, específicas, adaptadas, originais, regionais, como já afirmava Foucault. Daí este trabalho que não é econômico: a cada problema, recomeçar do zero. A melhor síntese só aparece num campo de diferenças máximas, num campo misturado. Do contrário, a síntese se resume à repetição. Uma metalinguagem, neste caso, seria a repetição de uma mesma chave para abrir todas as portas, diria Serres. Contudo, cada vez que se procura abrir uma fechadura diferente, é necessário forjar a chave específica, portanto, é claro, sem equivalente no mercado dos métodos. 

PARTe II

Vitalismo, Epistemologia e Arqueologia 
A razão é menos um poder de apercepção de relações essenciais na realidade das coisas ou do espirito do que um poder de instituição de relações normativas na experiência da vida.

Canguilhem (1990) 


\section{4 \\ Formas de Valoração do Vitalismo}

A partir do século XIX, o conceito de vida é problematizado. A noção de vida, no sentido que lhe é conferido pelas ciências biológicas, impõe-se, fundindo-se à idéia de vida normal ou patológica, de vida social, moral, política e econômica. Encontra-se, no vocabulário técnico e crítico da filosofia do século XX, a definição de vida fundamentada, antes de mais nada, na perspectiva biológica. ${ }^{33} \mathrm{Na}$ modernidade, este conceito situa-se na fronteira de diversos saberes e práticas, remetendo às mais variadas análises realizadas no campo da filosofia, das ciências e das práticas sociais.

Tais análises correspondem a diferentes formas de valorar a vida, as ciências da vida e os cientistas em nossa sociedade. Canguilhem ressalta a importância da biologia e da medicina para a filosofia, mas confere à vida mesma o papel de ajustar o valor atribuído pela tradição ocidental à cientificidade. Foucault, em suas análises arqueológicas, enfatiza a relação das ciências da vida com a filosofia e com as ciências do homem, para criticar, com uma visão bastante negativa de ciências do homem, o antropologismo da modernidade. Ele evidencia, ainda, em sua genealogia, a relação da biologia com os saberes e poderes que disciplinam e gerem a vida dos indivíduos e das populações, para problematizar o perigo desta forma de dominação da vida que as ciências representam. Sem dúvida, é preciso assinalar o caráter de imanência da relação entre saber e poder através do qual as análises foucaultianas tratam as

\footnotetext{
33 A definição encontrada é: "Conjunto de fenômenos de todo tipo (particularmente de nutrição e de reprodução) que, para os seres com um grau suficientemente elevado de organização se estendem do nascimento (ou da produção do germe) até a morte" (Lalande, 1980: 1.204). Tradução minha.
} 
ciências da vida, evidentemente, em termos das condições de possibilidade de sua utilização concreta e singular numa situação determinada. É claro que as análises genealógicas dirigem-se às ciências na medida em que podem ser tomadas como discursos, não para situar-se contra seus conteúdos, seus métodos ou conceitos, mas contra os efeitos centralizadores de poder que são vinculados à instituição e ao funcionamento de um discurso científico numa sociedade como a nossa.

François Jacob, por sua vez, apresenta, no nível dos princípios teóricometodológicos, uma visão bem mais positiva das ciências da vida que precisa ser levada a sério quando se pretende criticar o papel destes saberes. Seu argumento - o de que uma das maiores contribuições da metodologia científica destas ciências é ter facilitado a destruição do dogmatismo e da certeza de ter razão, ambos fundados na busca incessante de uma verdade intangível e eterna da vida, pois, os cientistas "já sabem que devem se contentar com o provisório e parcial” (Jacob, 1983: 7) - é reforçado pela afirmação de que não são as idéias científicas que levam ao racismo e ao ódio, mas é o ódio que lança mão da ciência para justificar o racismo, uma vez que, a seu ver, nenhum genocídio foi perpetrado para fazer uma teoria científica triunfar. É neste sentido que devemos compreender sua afirmação de que:

Nada é mais perigoso que a certeza de ter razão. Nada causa tanta destruição quanto a obsessão de uma verdade absoluta. Todos os crimes da História são conseqüência de algum fanatismo (...). No final deste século XX, é preciso que fique claro para cada pessoa que nenhum sistema explicará o mundo em todos os seus aspectos e detalhes. (Jacob, 1983: 8)

Tal visão mais positiva, não só no âmbito da política mas também no da ética, se explicita pelo estabelecimento, por ele operado, de uma relação entre diferentes formas de lidar com os pressupostos metodológicos das ciências da vida e os efeitos sociais e políticos decorrentes das diferentes formas de sua utilização. Com efeito, a idéia de provisoriedade do conhecimento científico e sua certeza abalada podem alterar consideravelmente o modo de utilização dos resultados científicos em termos de justificativas para certas ações sociais condenáveis como o fanatismo e o racismo, bem como as paixões que utilizam a ciência para sustentar sua causa. No plano em que se situa, a análise de Jacob é consistente e deve ser considerada como complementar às análises arqueológicas e genealógicas de Foucault. $\mathrm{O}$ argumento de Jacob situa-se no nível teórico e dirige-se 
às questões, aos problemas. É, portanto, considerando como provisória e parcial a concepção científica de vida, que ele discute, historicamente, a concepção de hereditariedade.

É deste ponto de vista que ele enfoca a principal característica da vida, a reprodução do organismo. Ele explicita a maneira pela qual a biologia moderna trata a vida, ao relacioná-la a um programa dos seres vivos que têm a capacidade de conservar a experiência passada e de transmiti-la pela hereditariedade. Em um ser vivo, tudo está organizado tendo em vista a reprodução, que é o que define vida. A chamada luta pela vida é o concurso pela descendência, é a fecundidade, cujo princípio determina que "ganham automaticamente os mais prolíficos, através de um combate sutil entre as populações e seu meio" (Jacob, 1983: 13). A hereditariedade é descrita, hoje, em termos de informação, mensagem, código. Uma informação, explica Jacob, é um elemento conduzido por uma mensagem, que é o suporte deste elemento e constitui sua significação. O objetivo da tradução de uma mensagem é a reprodução a partir da memória e a transmissão de caracteres adquiridos associados aos elementos essencialmente invariantes.

Com a teoria da informação, o organismo se define pela realização de um programa prescrito pela hereditariedade. Neste sentido, o ser vivo representa a execução de um projeto em que há transmissão de instruções que especificam as estruturas moleculares. Quando as mensagens são concebidas com um código determinado, a ciência pode avaliar a informação transmitida por características determinadas, introduzindo unidades de informação. O que é transmitido, de geração em geração, são os planos arquitetônicos do futuro organismo, sua estrutura e organização de funcionamento, assim como os meios para executar estes planos e coordenar as atividades do sistema.

A hereditariedade é descrita hoje em termos de informação, mensagens, código. A reprodução de um organismo tornou-se a reprodução das moléculas que o constituem. Não porque cada espécie química tenha capacidade de produzir cópias de si mesma, mas porque a estrutura das macromoléculas é minuciosamente determinada pelas seqüências de quatro radicais químicos contidos no patrimônio genético (...). O organismo torna-se assim a realização de um programa prescrito pela hereditariedade (...). O ser vivo representa certamente a execução de um projeto, mas que não foi concebido por inteligência alguma. Ele tende para um objetivo (...) preparar para a geração seguinte um programa idêntico. (Jacob, 1983: 10) 
Esta concepção de hereditariedade advém do estudo de camadas, cada vez mais profundas e ocultas, do ser vivo. De acordo com Foucault (2002) e Jacob, a explicitação destes níveis, pelas ciências biológicas, não resulta de um acúmulo de observações e experiências, mas de uma mudança radical na própria natureza do conhecimento. Esta mudança se deve não a um processo cumulativo linear de produção teórica nem ao aperfeiçoamento de equipamentos, mas a uma nova forma de olhar e enunciar o ser vivo como organismo.

A investigação histórica de Jacob mostra a existência de um domínio que o pensamento explora - o da vida -, instaurando uma ordem para estabelecer relações abstratas, de acordo com as observações, as técnicas, os valores e as interpretações da época. Em suas pesquisas, ele tenta demarcar as diversas etapas, enfatizando que uma época ou uma cultura caracteriza-se, fundamentalmente, pela natureza das questões que formula, pela forma de problematizar a vida, muito mais do que pela extensão dos conhecimentos científicos adquiridos. Afinal, afirma, o que caracteriza o conceito de vida é, sobretudo, o fato de que, como todo conceito, ultrapassa as fronteiras da ciência.

Canguilhem analisa, do ponto de vista da epistemologia, ao longo de sua obra filosófica, as mudanças pelas quais passa a biologia durante a segunda metade do século XX, na genética e na biologia molecular. Ele traça a história do conceito de vida tanto como forma, como experiência, quanto como conhecimento, desde Aristóteles até o presente. Tal reconstrução histórica fornece o fundamento para uma análise da maneira de conceituar a vida, no século XX, como lembra Paul Rabinow (1994).

Como Jacob, Canguilhem analisa as concepções de vida na perspectiva do animismo, do mecanicismo, da organização e da informação. Ele ressalta a necessidade de opor a vida à morte, tanto do ponto de vista da evolução das espécies quanto da herança genética do indivíduo.

Paradoxalmente, o que caracteriza a vida não é tanto a existência das funções da vida propriamente como deterioração gradual e cessação última. A morte é aquilo que distingue os indivíduos vivos no mundo, e a inevitabilidade da morte aponta para a aparente exceção às leis da termodinâmica que as coisas vivas constituem. Assim, a busca de sinais de morte é fundamentalmente uma busca por um sinal irrefutável de vida. (...). Do ponto de vista da evolução das espécies, a morte marca um final para a suspensão que a pressão da seleção natural garante aos mutantes temporariamente mais adaptados do que seus competidores para ocupar o contexto ecológico. (...) Do ponto de vista do indivíduo, 
a herança genética é como um aluguel, e a morte o encontro com a dívida, quando o aluguel deve ser reembolsado. É como se, após um certo tempo, fosse a dívida dos indivíduos de desaparecer, para reverter ao estado de matéria inerte. (Canguilhem, 1973: 69)

Para Canguilhem, a nova maneira de compreender a vida no século XX com a descoberta por Watson e Crick da estrutura da dupla hélice como sistema de informação, onde o código e o meio celular estão em constante interação - não repousa mais na estruturação da matéria e na regulação das funções, mas numa mudança de escala (de macro para micro) e de campo epistemológico, a saber, do campo da mecânica para o da informação, da comunicação. Num sentido importante, em seu entender, a nova forma de compreender a vida como informação retorna a Aristóteles, no que tange à consideração da vida como logos inscrito, convertido e transmitido na matéria viva. Contudo, de um modo que difere do aristotélico, a noção de telos da vida, sua relação de finalidade, é rejeitada, pois seria impossível compreender o erro, na perspectiva do programa genético da biologia molecular, através de uma teleologia.

Canguilhem rejeita este telos: como poderíamos compreender o erro, na perspectiva do programa genético da biologia molecular? Esta questão é fundamental para Canguilhem. Os erros genéticos são, agora, entendidos como erros da informação. Entre tais erros, contudo, um grande número é proveniente da má adaptação ao meio. Diante desta questão, ele retoma a noção de normalidade como uma ação situada, não como uma condição predeterminada. No nível mais fundamental da vida, os jogos do código e da decodificação abrem lugar para um acaso que, antes de ser doença, déficit ou monstruosidade, é uma perturbação no sistema informativo, um equívoco. No limite, a vida é aquilo que é capaz de erro. Talvez esta seja a razão pela qual o problema da anomalia atravesse toda a biologia.

A anomalia é, no domínio das ciências da vida, o alvo das explicações sobre as mutações e os processos evolutivos que elas induzem. Está nela a possibilidade de explicar o erro hereditário que faz com que a vida desemboque em um ser vivo que nunca se encontra completamente adaptado, "condenado a 'errar' e a se 'enganar"' (Foucault, 2000: 364), numa relativa mobilidade, inovando sempre. Daí a importância atribuída por Canguilhem ao cruzamento, nas ciências da vida, da antiga questão do normal e do patológico com a biologia e a teoria da informação, suas noções de código, mensageiro etc.

O erro ocorre quando o homem se coloca no lugar errado, numa relação errada com o meio, no lugar errado para receber a informação necessária à 
sobrevivência, à ação e ao crescimento. Temos que nos movimentar, errar e nos adaptar para sobreviver. Esta condição de errar ou mudar não é meramente acidental ou externa à vida, mas sua forma fundamental. De acordo com esta concepção de vida, o conhecimento é uma busca pela informação correta. Esta informação que só é encontrada, parcialmente, nos genes. Por que e como o código genético é ativado e funciona e quais são seus resultados são questões que, para Canguilhem, só o contexto da vida, o vivo, e a experiência, o vivido, podem responder.

Nos ensaios reunidos nesta parte do livro, investigam-se as ciências da vida não mais em função da caracterização da questão da historicidade da ciência e dos instrumentos metodológicos para sua análise. Aqui, a investigação encontra-se circunscrita em função do problema do conceito de vida, restringindo-se às formas de problematização da vida que conduziram ao problema do vitalismo em sua historicidade e em seu caráter de cientificidade, primeiramente, com Pasteur e, em seguida, com Canguilhem, Jacob e Foucault.

A análise destas formas de problematização desenvolve-se através de uma questão central: a do valor do vitalismo para a história das ciências da vida e seu papel na articulação que a epistemologia estabelece entre a filosofia, a ciência e a vida. Três hipóteses específicas são discutidas, evidenciando em que consistem os níveis epistemológico e arqueológico de análise. Em primeiro lugar, uma questão histórica: a de uma relação possível da ciência com a concepção vitalista de vida, como na microbiologia do século XIX. Em segundo lugar, a hipótese de que, ao atribuírem diferentes valores ao vitalismo na história da biologia, a epistemologia e a arqueologia não se contradizem, mas se complementam situando-se em níveis diferentes de análise. Finalmente, a hipótese de que, apesar das dificuldades, cada vez maiores, para justificar uma posição vitalista, hoje, é a própria biologia e sua forma de problematizar a vida que permitem a Canguilhem reiterar seu vitalismo. 


\section{5 \\ Pasteur e a Microbiologia}

Este ensaio resulta de uma pesquisa epistemológica da constituição da microbiologia com Pasteur, desenvolvida no contexto de uma análise filosófica da história da medicina no Brasil, a partir do século XIX, quando o modelo miasmático era dominante e foi substituído pelo modelo da microbiologia, aqui introduzido primeiramente a partir da obra de Pasteur. Daí toda uma série de estudos críticos vinculados, neste livro, à literatura de origem francesa.

Seu objetivo é muito pontual: fornecer, no âmbito de uma história dos conceitos, subsídios para a elaboração de uma história das ciências biomédicas que enfoca a introdução, em nosso país, do modelo pastoriano ${ }^{34}$ no final do século XIX, para especificar sua relação com um vitalismo, explicitado pela noção de ato vital, afirmado por Pasteur, compatível com o caráter de cientificidade de sua pesquisa.

A noção de pastoriano designa um novo momento da medicina, introduzido por Pasteur que implica uma revolução teórica e prática; teórica, isto é, que se passa no nível do saber, e prática, que se refere à medicalização da sociedade. A revolução pastoriana é um complexo de novos procedimentos médicos instituídos no século XX em função de um raciocínio causal. Incluem-se, neste complexo, identificação e isolamento dos microorganismos patogênicos, manipulação dos mesmos, métodos preventivos pela vacinação, soroterapia, teoria dos germes, atenuação de virulência dos microorganismos, além da transformação do gesto, da palavra, do vestuário, da arquitetura hospitalar, da legislação. O objeto deste estudo é a obra de Pasteur em seu aspecto

\footnotetext{
34 Toma-se, aqui, o conceito de Latour (1984) para especificar uma distinção em relação a pasteuriano e seu sentido de processo de destruição dos micróbios através da pasteurização.
} 
conceitual e epistemológico. Alguns pontos essenciais para a compreensão do surgimento deste novo modelo foram delimitados a partir dos principais conceitos operacionais na constituição de sua racionalidade, que termina por dar ao conceito de vida uma interpretação vitalista.

A trajetória de tais conceitos na obra de Pasteur (1922), estabelecida e editada por Valléry-Radot, obedece à ordem cronológica de sua pesquisa. Os trabalhos de Pasteur estavam espalhados na Academia de Ciências da França e na Academia de Medicina, em revistas e jornais científicos, além dos volumes que continham os estudos sobre o vinho, a cerveja e a doença do bicho-daseda. ${ }^{35}$ De acordo com esta ordem, veremos que as teses de química e física e os trabalhos sobre cristalografia o conduziram ao estudo das fermentações. Surge, primeiro, a concepção de dissimetria molecular nos produtos orgânicos naturais, que leva à questão da influência desta dissimetria nos fenômenos de ordem fisiológica, como um prolongamento de suas investigações provenientes do campo da química molecular.

Ter a obra de Pasteur como objeto da análise corresponde a um recuo histórico indispensável ao estudo do surgimento, no Brasil, de um novo tipo de saber e de práticas médicas, na medida em que é com a introdução do modelo pastoriano que esta mudança se estabelece. Neste recuo, tomamos como ponto de partida a importância de uma história conceitual, em detrimento de uma história descritiva, factual, que celebra datas, relata descobertas, traça biografias ou procura precursores e quadros doutrinais; em detrimento também de uma história das idéias. Conforme afirma Foucault em As Palavras e as Coisas (1966), as histórias das idéias, em geral, atribuem ao século XVII uma nova curiosidade que teria fornecido às ciências biológicas uma amplitude e uma precisão insuspeitáveis para este domínio científico. A tal fenômeno atribui-se um certo número de causas e várias manifestações essenciais.

Dentre elas elas, encontram-se tanto os privilégios da observação - devido aos poderes a ela atribuídos por Bacon e ao aperfeiçoamento técnico dela derivados que teriam ocasionado o aperfeiçoamento do microscópio - quanto o prestígio da física, que fornece um novo modelo de racionalidade, com a introdução da experimentação e da teoria nas análises das leis do movimento ou da reflexão do raio de luz. Os mesmos procedimentos - experiências, observações e cálculos - puderam, então, ser utilizados também na busca

\footnotetext{
35 São sete tomos: t.1. A dissimetria molecular; t.2. As fermentações e as gerações ditas espontâneas; t.3. Os estudos sobre o vinagre e o vinho; t.4. Os estudos sobre a doença do bicho-daseda; t.5. Os estudos sobre a cerveja; t.6. As doenças virulentas, os vírus-vacina e a profilaxia da raiva; t.7. Textos científicos e literários.
} 
das leis que poderiam organizar o domínio mais complexo dos seres vivos. As causas são atribuídas ainda a outros fatores, como o interesse econômico pela agricultura, a curiosidade pelas plantas e animais exóticos que teriam ocasionado grandes viagens de exploração etc.

Outro tipo de procedimento histórico que encontramos é a descrição das várias formas tomadas pelas ciências da vida. Elas teriam sido mecanicistas, primeiramente, sob a influência de Descartes, assim se mantendo até o final do século XVIII. Os primeiros esforços de uma química apenas esboçada as teria marcado; porém, ao longo do século XVIII, temas do vitalismo teriam sido privilegiados para serem formulados, mais tarde, numa doutrina unitária. Neste caso, o mecanicismo cartesiano teria sido, de início, o instrumento que possibilitou uma transferência da racionalidade mecânica para a descoberta de uma outra racionalidade, a racionalidade do ser vivo, apesar de ter-se apresentado, mais tarde, como um obstáculo ao progresso das ciências da vida.

Há também a história da contradição entre uma ciência demasiado ligada à astronomia, à mecânica e à ótica, e uma outra que já supõe o que pode haver de irredutível e de específico nos domínios da vida, onde a irreligião e toda uma intuição confusa de vida conduziriam para o século XIX. Nessa época, teria sido alcançada uma finalização positiva e racional para as tentativas, ainda obscuras e encadeadas, do século XVIII. Através de um leque de problemas, os filósofos da ciência tentam reconstruir os grandes debates, acreditando reencontrar os vestígios de um conflito maior entre uma metafísica e uma ciência que já busca sua autonomia. $O$ problema destas histórias é não conseguirem atingir a rede que possibilita ligar, umas às outras, pesquisas tão diferentes como as tentativas de taxonomia e as observações microscópicas, essenciais para a compreensão deste complexo epistemológico que constitui a racionalidade da microbiologia.

Para tal, abordaremos alguns pontos essenciais, partindo do pressuposto de que a ciência não pode ser reduzida à teoria, uma vez que não se confunde com seus resultados. Podemos, para tanto, utilizar a noção de ciência como um tipo de saber que se constitui num processo de busca da verdade, cada vez mais depurada dos erros iniciais, por meio de um discurso, isto é, de um conjunto de proposições articuladas de modo sistemático, mas que não é um discurso exclusivamente verdadeiro. Estamos levando em consideração seu caráter de questionamento que se constitui de proposições verdadeiras e falsas; não apenas as soluções que foram mantidas até o presente como verdades. $\mathrm{O}$ erro tem uma positividade histórica, ele é necessário, como explica Canguilhem, 
por ser um caminho indispensável à formulação de novos saberes, sempre que contribui para a construção de conceitos fundamentais para compreender a configuração de uma nova racionalidade.

É neste sentido que, ao tomarmos a obra de Pasteur, importam todos os passos do processo, mesmo aqueles abandonados posteriormente; importa aquilo que Bruno Latour (1984) chama de um deslocamento transversal de Pasteur. Ou seja, um deslocamento que é percebido da seguinte maneira: cada vez que acreditamos que Pasteur vai prosseguir no desenvolvimento de uma ciência em que encontrou algum sucesso, ele escolhe dar um passo para o lado, a fim de abordar um outro problema que tenta resolver com os meios adquiridos na disciplina que acaba de abandonar, inaugurando, a cada vez, uma disciplina nova; abandona-os através do mesmo movimento para o lado, e assim, sucessivamente, ao invés de se aprofundar cada vez mais, mantendo-se numa única perspectiva.

Para traçar tal deslocamento, estudaremos a formulação dos conceitos que constituem a base da microbiologia e que foram construídos atravessando campos que, normalmente, se distinguiam. Desta forma, pretendemos apreender as condições de possibilidade da relação de domínios diferentes, como o exemplo citado por Latour ao referir-se aos Anais do Instituto Pasteur (1887-1919). De acordo com Latour, os Anais não podem ser considerados nem médicos, nem higienistas, nem biológicos, apesar de poderem ser considerados tudo isto ao mesmo tempo. Isso porque uma revista de higiene se limitaria ao urbanismo ou ao saneamento; uma revista de entomologia se contentaria em descrever os ciclos de vida dos mosquitos; uma revista de imunologia falaria apenas dos corpos e de suas reações, sem se ocupar com os micróbios. Nos Anais, todas estas regiões se cruzam.

A análise dos processos de formulação conceitual nos permite compreender este tipo de procedimento transversal de busca da verdade, uma vez que os procedimentos científicos têm, conforme explica a epistemologia, uma normatividade interna que se exprime no conceito. Uma abordagem histórica do surgimento da microbiologia requer um estudo conceitual. São privilegiados, nesta análise, ao contrário do que acreditamos à primeira vista, os conceitos de dissimetria molecular, fermentação e atenuação da virulência, e não exatamente o de micróbio. Isto porque micróbio é já resultado e não condição de possibilidade, pelo que depreendemos da obra de Pasteur.

O termo micróbio foi, conforme assinala Pasteur, proposto por Sédillot em 1878, para designar os microorganismos. Ele reúne o conceito de vida e 
as experiências do microscópio. Sua relevância é estabelecida no momento em que se explicita, cientificamente, a importância de uma noção de vida independente de seu tamanho: quando os organismos infinitamente pequenos passam a ser reconhecidos como fundamentais na formação do universo, principalmente, no que tange ao problema da formação das doenças. A idéia de micróbio, tal como a concebe Pasteur, é a expressão de um procedimento que associa, intimamente, a biologia, a química, a física e a cristalografia, para o estudo da vida. A vida constitui a questão fundamental para o surgimento, no século XIX, de saberes que fundam o domínio das ciências biomédicas.

A questão da vida faz emergir a microbiologia a partir dos conceitos de dissimetria molecular - proveniente dos cristalógrafos - e de fermentação proveniente dos estudos dos naturalistas e dos fisiologistas. No nível arqueológico, podemos dizer que esta indagação não se limita à região das ciências biomédicas.

\section{VIDA NO LABORATÓRIO}

O texto que se segue, apesar de longo, merece ser citado. Surpreende sua concisão. Ele apresenta inúmeros elementos constitutivos da noção científica moderna de vida. Sua construção conceitual permite entrever a configuração cognitiva do que se chama revolução pastoriana:

eu creio poder deduzir que não conseguiremos ultrapassar a barreira que estabelece, entre os dois reinos, universal e orgânico, a impossibilidade de produzir, por nossas reações de laboratório, substâncias orgânicas dissimétricas, a não ser que introduzamos, nestas reações, influências de ordem dissimétrica. O sucesso nesta via daria acesso a um mundo novo, de substâncias e de reações e provavelmente, também, de transformações orgânicas. É aí que deveria se colocar o problema, não apenas de transformação das espécies, mas também da criação de espécies novas. Uma vez que conseguimos encontrar o universo do ácido tartárico destrógiro, sem nenhuma dúvida, conseguiremos, um dia, possuir todos os princípios imediatos inversos daqueles que existem; quando quisermos ir ainda mais longe na ordem fisiológica, quando quisermos fazer passar estes novos princípios imediatos nas espécies vivas pela nutrição, a grande dificuldade, eu temo, será de levá-la ao devir próprio das espécies, e que contém em potência, o germe de cada uma delas, germe onde se manifestará sempre a dissimetria dos princípios imediatos atuais (...). $\mathrm{O}$ papel da dissimetria molecular foi introduzido igualmente como fator dos fenômenos da vida, no dia em que se constatou que um fenômeno 
organizado vivo fazia fermentar facilmente o ácido tartárico destrógiro e não seu inverso - o ácido tartático levógiro - e que seres tomavam do ácido tartárico destrógiro o carbono necessário à sua nutrição, de preferência ao carbono do ácido levógiro. Então, visto que há dissimetria nos princípios imediatos naturais, principalmente naqueles que poderíamos considerar primordiais, isto é, nos princípios imediatos constitutivos de célula viva, já que os vegetais produzem substâncias dissimétricas simples à exclusão de seus inversos, já que, contrariamente ao que acontece nas reações de nossos laboratórios, o reino vegetal (...). (Pasteur, 1922, t.1: 361) $)^{36}$

A dissimetria molecular é um conceito fundamental para compreender este novo domínio de saber, na medida em que constitui um ponto de partida para a concepção de fermentação e para a formulação do conceito de vida. Resume-se nos seguintes princípios: existem substâncias cujo agrupamento atômico é dissimétrico, e este agrupamento se traduz, externamente, por uma forma dissimétrica e por uma ação de desvio sobre o plano de luz polarizada; estes agrupamentos atômicos têm seus inversos possíveis, cujas formas são idênticas àquelas de suas imagens e as quais têm uma ação inversa sobre a luz polarizada.

Para Pasteur, a dissimetria parece ser uma necessidade da constituição das moléculas que se edificaram sob a influência da vida. É a dissimetria molecular, conceito formulado em cristalografia ${ }^{37}$ (Jacob, 1983), que vai permitir caracterizar os organismos do ponto de vista da vida. Para ele, todos os produtos artificiais de laboratório têm imagens (no que tange à configuração espacial das moléculas que os compõem) que podem ser sobrepostas. Ao contrário, a maioria dos produtos orgânicos naturais, que desempenham um papel essencial nos fenômenos da vida vegetal e animal, são dissimétricos. Os compostos que caracterizam os organismos vivos possuem uma qualidade que os distingue dos mesmos compostos produzidos no laboratório. Em todo ser vivo, existe uma força de origem desconhecida que introduz uma dissimetria nas atividades químicas e que não pode ser imitada pela experimentação.

\footnotetext{
36 Tradução minha de todas as citações desta obra. Note-se que os textos escritos por Pasteur encontram-se reunidos em edição aqui utilizada, estabelecida por Louis Pasteur Vallery-Radot (1886-1970), médico e escritor, autor de estudos sobre Pasteur.

${ }^{37}$ A cristalografia é, como explica Jacob, uma ciência que se constitui a partir do momento em que se define a espécie cristalina pela constância do ângulo das faces, pelos sistemas de simetria, pela regularidade das truncaturas nos vértices em função do sistema de simetria dos cristais. A cristalografia é um discurso sobre a natureza dos cristais considerados em sua identidade consigo mesmos, universais, diferentes dos vegetais e dos animais, e independentes do uso que dela se faz.
} 
Assim, Pasteur tem elementos para formular a questão que vai levar a ciência para o laboratório: é possível introduzir, nas reações de laboratório, influência de ordem dissimétrica? Pois, para ele, no momento da formação de uma substância, quando os átomos elementares, que devem constituir as moléculas do corpo, estão presentes e a combinação vai se produzir, uma influência secreta agrupa, de forma dissimétrica, os átomos, caso se trate de uma combinação de ordem vital (Pasteur, 1922, t.1) - fato que diz respeito às condições mais escondidas da vida, e que a equação entre o ato químico e o ato vital poderiam esclarecer. Através desta questão, surgida no estudo da dissimetria molecular, a química se introduz no mundo dos seres microscópicos. $\mathrm{O}$ ato químico analisado é o da fermentação considerado em sua correlação com o ato vital.

Ele utiliza a hipótese quantitativa de Haüy para desenvolver o estudo dos cristais. Segundo esta hipótese, todos os cristais são formados por pequenas moléculas cristalinas (moléculas integrantes) em formas de paralelepípedos dispostos regularmente. O conceito de Haüy é importante para a compreensão do trabalho de Pasteur, na medida em que fundamenta a idéia de que a molécula não é uma entidade hipotética, lógica e indefinida, mas um objeto concreto que ocupa um espaço definido. Haüy concebeu certos cristais de quartzo como tendo faces dispostas em forma helicoidal, sendo que alguns destes cristais apresentavam faces em hemiedros (com dois lados) dirigidas para a esquerda ou para a direita.

A análise da formação do quartzo proporcionou a compreensão de substâncias que cristalizavam formando uma espécie de caracol com uma simetria em espiral. A partir daí, concebeu que a cada uma das estruturas corresponde uma forma invertida, idêntica em todos os aspectos, do mesmo modo que há uma mão direita e uma esquerda ou um objeto refletindo-se no espelho. À hipótese de Haüy, Pasteur associa a vertente ótica de Malus (1775-1812), que fornece a noção de plano de polarização da luz e sua rotação para a direita ou para a esquerda.

No final do ano de 1808, afirma Pasteur:

Malus anunciou que a luz refletida por todos os corpos opacos ou diáfanos contraía novas propriedades bastante extraordinárias, que a distinguiam essencialmente da luz transmitida diretamente pelos corpos luminosos (...). Malus chamou polarização esta modificação. (Pasteur, 1922, t.1: 315) 
Quatro anos mais tarde, Biot mostra que esta propriedade aparecia também em soluções orgânicas, especialmente o ácido tartárico ou seus sais. Pasteur toma estes estudos como base para analisar a constituição das moléculas, partindo de suas formas cristalinas, principalmente, no ácido tartárico. Nesta análise, ele demonstra quatro pontos importantes: 1) o ácido tartárico pode cristalizar sob duas formas simétricas, diferentes entre si, como a luva da mão esquerda e a luva da mão direita; 2) uma dessas formas faz girar o plano de polarização da luz para a direita, e outra o faz girar para a esquerda. Pasteur tenta estabelecer relações entre a forma cristalina, a composição química e o sentido da polarização rotativa, donde parte para a fisiologia; 3) o chamado ácido racêmico, oticamente inativo, não é mais do que uma mistura de proporções iguais dos ácidos destro-tartárico (direita) e levo-tartárico (esquerda); 4) o ácido racêmico pode se tornar oticamente ativo se, por diversos procedimentos - um deles a fermentação (a ação de determinados microorganismos) -, é destruída a metade destrógira ou a metade levógira da mistura.

Este conjunto de fatos, conforme explica Entralgo (1986), foi interpretado em dois planos: num plano, imediatamente próximo à observação, as propriedades óticas de uma molécula e, por extensão, suas propriedades químicas são concebidas como dependentes não só do movimento dos átomos que a compõem, mas da respectiva situação dos mesmos no espaço. No outro plano, o da estrutura de certas moléculas - as eletricidades positiva e negativa, os pólos norte e sul da força magnética -, a dissimetria é interpretada como uma lei fundamental do universo e que a vida, a constituição e a atividade própria dos seres vivos têm uma de suas bases estruturais na ação de forças dissimétricas.

Todos os corpos se dividem em duas classes, os corpos com imagens que podem se sobrepor e os corpos com imagens que não podem se sobrepor: os corpos com arranjos de átomos dissimétricos (...). Todos os produtos artificiais de laboratório e todas as espécies minerais têm imagens que podem ser sobrepostas. Ao contrário, a maior parte dos produtos orgânicos naturais (eu poderia mesmo dizer todos, se eu tivesse que nomear apenas aqueles que têm um papel essencial nos fenômenos da vida vegetal e animal), todos os produtos essenciais da vida são dissimétricos... (Pasteur, 1922, t.1: 331)

Esta hipótese, suscitada principalmente pelo fato de que a destruição pela fermentação do ácido tartárico destrógiro é específica dele e deixa, portanto, indene o ácido tartárico levógiro, o levou a demonstrar, experimentalmente, 
que a lei da dissimetria regula a germinação e o crescimento das plantas. Associando a cristalografia, a química e a ótica moleculares, Pasteur elaborou uma lei geral que lhe permitia reconhecer, nos princípios imediatos da célula viva, uma propriedade fundamental que estabelecia uma demarcação entre os produtos minerais ou artificiais e os produtos vivos (1847 a 1857): "Os produtos artificiais não têm dissimetria molecular; e eu não poderia indicar a existência de uma separação mais profunda entre os produtos nascidos sob a interferência da vida e todos os outros" (Pasteur, 1922, t.1: 333).

Não tiveram êxito os experimentos desta teoria; mas o aparecimento do fenômeno da fermentação no pensamento de Pasteur desempenha papel essencial na investigação pastoriana, conduzindo-o ao estudo dos fenômenos de ordem fisiológica como um prolongamento de suas descobertas sobre a química molecular:

a prova que ela nos dará manifesta a influência da dissimetria nos fenômenos da vida. Já vimos a dissimetria intervir como modificador das afinidades químicas; mas tratava-se de reações puramente minerais, artificiais, e sabemos toda a prudência que devemos ter na aplicação dos resultados dos laboratórios aos fenômenos da vida. Conservei todos os aspectos desta lição até o momento em que reconheci a maneira mais certa pela qual a dissimetria molecular se oferecia como modificador das afinidades químicas, não mais nas reações de natureza morta, mas naquelas de ordem fisiológica, nas fermentações. (Pasteur, 1922, t.1: 342)

De acordo com Pasteur (1922, t.1: 360),

todos os produtos minerais e todas as substâncias orgânicas obtidas artificialmente nos laboratórios são privados da dissimetria molecular e da ação correlativa sobre a luz polarizada, propriedades que são inerentes às substâncias orgânicas naturais e as mais consideradas do ponto de vista da fisiologia.

Desta forma, a prática da biologia se associa, intimamente, à prática da química. Os desvios das fermentações, as doenças de cerveja ou do vinho provocam a formação de compostos dissimétricos. Estão, portanto, associados à presença da vida. Traça-se uma profunda divisão entre o mundo orgânico e o inorgânico, quando Pasteur percebe que, para imitar algum fenômeno natural, como a preparação de uma substância destrógira ou levógira, é necessário recorrer à ação da dissimetria. Esta linha divisória não é uma questão puramente química, mas de forças. A vida é considerada como dominada por 
ações dissimétricas que têm uma influência cósmica. A definição da natureza dissimétrica leva à afirmação da existência de uma força dissimétrica cósmica, determinante da configuração destrógira ou levógira da molécula:

Qual pode ser a natureza destas ações dissimétricas? Eu penso que elas são de ordem cósmica. $\mathrm{O}$ universo é um conjunto dissimétrico, e eu estou persuadido de que a vida, tal qual ela se manifesta para nós, é uma função da dissimetria do universo ou das conseqüências que ela acarreta. O universo é dissimétrico, pois se colocássemos diante de um espelho o conjunto dos corpos que compõem o sistema solar, movendo-se com os movimentos que lhes são particulares, teríamos no espelho imagens que não podem ser superpostas à realidade (...). (Pasteur, 1922, t.1: 361)

Apesar da afirmação da inviabilidade da produção artificial de dissimetria molecular, fica estabelecida uma inter-relação da química com o estudo da vida. Esta inter-relação quebra, no saber do século XIX, a barreira até então existente entre as reações que ocorrem no vivo e as que ocorrem no laboratório. Até meados do século XIX, observavam-se os seres vivos, mas procurava-se não alterar sua ordenação quando se fosse analisá-los. Consideravam-se os organismos em sua totalidade, com o objetivo de especificar-lhes as propriedades e as estruturas. Os organismos eram comparados entre si para determinar as analogias e as diferenças. Era a natureza que realizava as experiências para o naturalista. Só os fisiologistas intervinham, raramente, modificando, de forma deliberada, as condições de vida para observar os efeitos produzidos. Contudo, atuavam sobre o organismo em sua totalidade, nunca em seus fragmentos. A obrigação de recorrer à força vital para justificar as características moleculares do organismo levantava, entre a química do vivo e a do laboratório, uma barreira intransponível.

Na segunda metade do século XIX aparece algo totalmente novo, isto é, a idéia de intervir mudando as condições de vida: analisa-se, decompõe-se, mede-se. $\mathrm{O}$ cientista não olha mais para o ser vivo através de uma observação passiva em que se limita a constatar as variações que se introduzem, espontaneamente, num sistema. $\mathrm{O}$ cientista da época de Pasteur intervém diretamente, extrai um órgão, isola-o, faz com que funcione, muda as condições, analisa as variáveis. Até então, considerava-se que penetrar num organismo só podia alterar sua natureza e prejudicar seu funcionamento; a partir do século XIX, com o surgimento do conceito de vida, é possível se pensar em termos de intervir, sem que a qualidade do vivo seja, necessariamente, destruída pelas condições artificiais produzidas pela experimentação. 


\section{Ato VITAL}

Pasteur estabelece uma relação entre o caráter de dissimetria molecular próprio das substâncias orgânicas, os fenômenos de fermentação e ato vital. Ao estabelecer esta relação, coloca-se a questão: o que é necessário fazer para imitar a natureza? Como é possível transformar um corpo inativo em corpo ativo? Pois,

transformar um corpo inativo em outro corpo inativo, que tem a faculdade de se resolver simultaneamente em um destrógiro e em seu simétrico, não é nada comparável à possibilidade de transformação de um corpo inativo em corpo ativo simples. É isto que nunca fizemos; é isto, ao contrário, que a natureza viva faz sem cessar diante de nossos olhos... (Pasteur, 1922, t.1: 365)

É necessário fazer agir forças dissimétricas que apontam a linha de demarcação entre o reino mineral e o reino orgânico, uma vez que, para imitar a natureza, isto é, para preparar um corpo destrógiro ou levógiro, é necessário fazer intervir a ação da dissimetria. Para Pasteur, cada fermentação é expressa por uma equação que pode ser assinalada de uma maneira geral, mas que, no detalhe, está submetida às variações que existem nos fenômenos da vida. Acontece na fermentação dos microorganismos o mesmo que acontece na nutrição dos animais: ambas refletem atividades químicas que representam o metabolismo do ser vivo.

A fermentação não pode, neste caso, ser compreendida como um ato isolado, misterioso e sem explicação. Ela é a conseqüência de um ato vital, de um fenômeno de nutrição, completando-se em condições determinadas. Ela tem um papel fisiológico. No microscópio, Pasteur observa a existência de espécies diferentes de fermentos: uma espécie responsável pela fermentação alcoólica, outra pela ácida; são diferentes, porém, sempre são correlativas de um ato vital. $\mathrm{O}$ estudo dos dois tipos de fermento é, muitas vezes, abordado pelos historiadores como decorrente de exigências industriais de descobrir as causas das fermentações defeituosas. Sem dúvida, este é um fator interessante. Mas não explica como foi possível a Pasteur conduzir sua pesquisa da cristalografia para a fermentação como fator biológico, ao tentar introduzir a dissimetria nos fenômenos químicos.

As fermentações já vinham sendo estudadas por Liebig (1803-1873), Berzelius (1779-1849), Claude Bernard (1813-1878), para os quais elas eram um fenômeno puramente químico. Contra eles se posiciona Pasteur, afirmando 
que toda fermentação corresponde à atividade de um micróbio. Tal concepção baseou-se na conhecida polêmica com Pouchet, que é a discussão da seguinte questão: poderia o vivo engendrar-se do não-vivo? Segundo Pouchet, os germes encontrados na fermentação surgem, espontaneamente, no líquido a ela suscetível, visto que podem existir sem ar atmosférico. Por esta razão, Pouchet nega a existência a priori de germes de seres organizados, uma vez que os mesmos necessitariam do ar atmosférico para existir.

Pasteur, em 1857, afirma a esse respeito que:

ou os fermentos organizados eram gerações espontâneas, se o oxigênio, enquanto oxigênio, os fazia nascer no contato com matérias organizadas; ou bem esses fermentos organizados não eram gerações espontâneas, e então não era apenas como oxigênio que esse gás agia, mas como excitante de um germe trazido ao mesmo tempo ou já existente nas matérias. (Pasteur, 1922, t.2:VII)

Esta questão se fortalece na medida em que a vida é considerada o germe, e o germe sinônimo de vida:

Ora, quem poderia dizer qual seria o devir dos germes, se pudéssemos substituir nestes germes os princípios imediatos, albumina, celulose etc., por seus princípios dissimétricos inversos? A solução consistiria (...) na descoberta da geração espontânea. (Pasteur, 1922, t.1: 337)

Entralgo ressalta, contudo, o fato de que Pasteur não chegou a conhecer o definitivo descobrimento dos fermentos solúveis e ultrafiltráveis e, portanto, o sucesso da teoria de Liebig e Bernard. A tese pastoriana, afirma Entralgo (1986), hoje, só pode ser mantida substituindo o termo micróbio ativo na fermentação, pelo termo fermento e entendendo-o como enzima, isto é, não lhe atribuindo condição de organismo vivo. Para Pasteur, a concepção dos fermentos como seres vivos forma-se com o apoio mútuo de várias ciências que demonstram ser a hipótese de uma geração espontânea uma quimera.

Entre 1857 e 1858, ele admite que os fermentos propriamente ditos são seres vivos e que os germes dos organismos microscópicos abundam na superfície de todos os objetos, na atmosfera e nas águas, correlacionando os fenômenos da fermentação e o caráter de dissimetria molecular próprio das substâncias orgânicas naturais. A partir de 1859, ele se questiona sobre a origem dos fermentos organizados, com base nas ligações existentes entre as propriedades químicas, óticas e cristalográficas de certos corpos, para estabelecer sua constituição molecular, tomando como base a hipótese de que o 
fermento pode intervir na constituição molecular dos corpos provenientes da fermentação. A teoria da fermentação seria, na opinião de Pasteur, matematicamente estabelecida, no momento em que a ciência estivesse suficientemente avançada para fazê-lo. Mas, em seu tempo, o grande desafio era retomar a explicação da geração espontânea e negá-la. É o estudo microscópico da vida que faz ressurgir este debate no século XIX.

A geração espontânea consiste na formação de indivíduos vivos, destituídos de pais, a partir de substâncias retiradas do meio ambiente. Segundo Pouchet, a geração espontânea seria o surgimento de microorganismos sem ar (ou calcinados ou passados através de substâncias químicas). Contra esta teoria, coloca-se a hipótese de que, em todos os casos em que a geração espontânea parece acontecer, houve algum germe existente no ar que penetrou no meio, antes estéril, e se reproduziu, povoando-o de microorganismos. Pasteur analisa, experimentalmente, a poeira do ar, a partir de que chega à formulação da idéia de corpúsculos organizados, semelhantes a germes, os quais produzem microorganismos. Esta idéia conduz a um aprofundamento do estudo da fermentação e dos fermentos; seu objetivo é determinar as causas da produção simultânea e sua verdadeira origem.

Dentre as questões sobre as fermentações propriamente ditas, a mais relevante, de acordo com Pasteur, refere-se à origem dos fermentos: de onde vêm estes agentes misteriosos, tão fracos em aparência, tão potentes na realidade, que, com um peso mínimo e características químicas exteriores insignificantes, possuem uma energia excepcional. Este foi o problema que conduziu a investigação pastoriana ao estudo das gerações espontâneas. A idéia de produção organizada opõe-se à de geração espontânea. A questão que guia as análises de Pasteur neste sentido é a seguinte: pode a matéria organizar-se por si mesma? A organização é compreendida como a constituição molecular dos corpos, a qual intervém nas propriedades fisiológicas:

Devo confessar, com efeito, que minhas pesquisas são dominadas há muito tempo por este pensamento: que a constituição dos corpos, do ponto de vista da dissimetria molecular, que são a mesma coisa, aliás, tem um papel considerável nas leis mais íntimas da organização dos seres vivos e intervém nas suas propriedades fisiológicas mais íntimas. (Pasteur, 1922, t.2: 4)

No século XIX, reapareceu a doutrina das gerações espontâneas para explicar a origem de seres tão variados que o microscópio permitia ver nas infusões 
das matérias vegetais ou animais, pois nada havia nelas que parecesse geração sexual. Contudo, mesmo nos seres microscópicos, o vivo só nasce do vivo. Onde se encontram bacilos, já existia um bacilo idêntico para engendrá-los. Desta forma, retomando as antigas experiências de Spallanzani, aperfeiçoando-as, executando-as com o rigor da química, Pasteur exclui qualquer possibilidade de geração espontânea.

Antes, o poder de fermentação era um caráter não do ser vivo considerado em sua totalidade, mas de determinados componentes, conforme afirmam Liebig e Berzelius. Com Pasteur, trata-se de algo inteiramente diferente. Se os seres vivos introduzem, nas reações químicas, uma dissimetria molecular, esta, por sua vez, assinala a presença de um ser vivo. O procedimento da ciência, neste caso, inverte-se. Quase sempre este vai do conhecimento teórico para as questões práticas que dizem respeito aos problemas do homem. O caminho tomado aqui é o oposto. A partir das dificuldades encontradas pelas indústrias de cerveja, vinho e álcool, encontra-se o meio de associar, intimamente, a prática da biologia à prática da química. Os desvios das fermentações, as doenças da cerveja ou do vinho provocam a formação de compostos dissimétricos. Estão, portanto, associados à presença de seres vivos, isto é, à multiplicação de seres organizados.

As anomalias da fermentação transformam-se, simplesmente, em outros tipos de fermentações. Seja ela alcoólica, amilolítica etc., toda fermentação é acompanhada pela multiplicação dos seres microscópicos. "A fermentação alcoólica é um ato correlativo da vida, da organização de glóbulos, não da morte ou da putrefação (Pasteur, 1922, t.7: 566). De acordo com esta compreensão, o anormal não fornece um modelo que a fisiologia tenta reproduzir, mas proporciona o lugar onde a experiência pode atuar e assinala o fenômeno que a análise transforma em processo fisiológico.

A fermentação, a putrefação e a combustão são, para Pasteur, três fenômenos que concorrem para a destruição da matéria organizada. A matéria organizada, que tinha tido vida, conserva, depois da morte (desorganização da matéria), uma vitalidade própria, sob a influência da qual as partes separadas se reúnem outra vez em certas condições favoráveis. Com o estudo da fermentação, desaparece a antiga forma de vitalismo a que a biologia, inicialmente, recorrera para adquirir independência. Diante do desenvolvimento da ciência experimental, da química orgânica e biológica, não se pode mais, a não ser através do misticismo, invocar um princípio de origem desconhecida, algo que escapasse, inteiramente, às leis da física. 
Se a física parece não poder explicar o conjunto de fenômenos da vida, não é mais devido a uma força exclusiva do mundo vivo, impossível de ser conhecida. É devido, porém, a limites inerentes à observação e à análise, à complexidade dos seres vivos em relação à matéria. $\mathrm{O}$ que poderia impor um limite ao conhecimento da vida não é mais uma diferença de natureza entre o vivo e o inanimado, mas a insuficiência de nossos meios ou de nossa possibilidade de análise. Por isto, não se trata mais de recorrer a uma força misteriosa para justificar a origem, as propriedades, o comportamento dos seres vivos. Trata-se de saber se as leis já encontradas na análise da matéria bastam ou se é preciso encontrar outras. Desta forma, Pasteur introduz, na questão da fermentação, o grande capítulo da vida.

\section{VIDA E MICROSCÓPIO}

O aparecimento da microbiologia, no século XIX, deve-se à possibilidade da conjugação de técnicas de laboratório, efetivadas no microscópio, com o surgimento do conceito de vida. O microscópio já era conhecido desde o século XVII, mas a microbiologia ainda não era possível. Tal possibilidade é dada pela passagem do estudo dos seres vivos para o estudo da vida, considerada como um conjunto de fenômenos apresentados por certos corpos, cujas funções essenciais seriam a nutrição e a reprodução. A idéia de vida se apresenta como um novo objeto para as pesquisas desenvolvidas no século XIX. Sua concepção é o pano de fundo para mudanças profundas no saber.

Segundo Claude Bernard, a vida compõe-se de síntese e destruição orgânica, e todas as ações de decomposição orgânica referem-se à fermentação. Ele acredita numa oposição necessária entre os fenômenos da vida, ou de síntese, e os fenômenos de morte, ou de destruição, ou melhor, entre a vida propriamente dita e as fermentações. Já Pasteur pensa a vida em termos de organização dos glóbulos, ou seja, de matéria organizada. Para ele, a morte é putrefação e a destruição da matéria organizada. Contudo, a morte não se coloca, em seu pensamento, como oposta à vida, mas como condição necessária de sua perpetuação na superfície do globo; a vida é imanente à morte.

O conceito de vida significa, em seu caráter mais elementar, germe e devir, idéias que implicam reprodução, nutrição, desenvolvimento. Todos os fenômenos da vida reduzem-se ao germe e suas transformações: "O mistério da vida não está nas manifestações da vida no seres adultos, grandes ou pequenos, ele está inteiro nos germes, na célula embrionária e em seu devir" 
(Pasteur, 1922, t.7: 29). Estas condições de mudança no saber se originam na maneira de olhar o organismo, na forma de interrogá-lo, de elaborar questões a que a ciência deve responder. A nova maneira de olhar faz ver a vida e não mais os seres vivos. Até o século XIX, a noção de vida, no sentido em que ela é tomada então, não existia. $O$ que existia era a idéia de seres vivos e o estudo dos mesmos que apareciam através de uma grade do saber constituída pela história natural. Se a organização interna dos seres vivos é estudada, e se novos métodos são utilizados, é porque a vida, como forma fundamental de saber, fez aparecer novos objetos, como, por exemplo, a relação entre o caráter de um determinado elemento e a sua função.

A questão da função aparece com Cuvier. Definida como a forma não perceptível do efeito a ser esperado, a função vai servir de meio termo constante, e permitir relacionar, um ao outro, os conjuntos de elementos desprovidos de qualquer identidade aparente. Esta referência à função estabelece novas relações - coexistência, hierarquia interna, dependência em relação ao plano de organização - analisadas nos fenômenos da vida, originando formas de classificação que abandonam a morfologia, conforme veremos mais adiante. Enquanto os seres vivos formam uma ou mais classes na série de todas as coisas do mundo, a vida é concebida como um caráter na distribuição dos seres, isto é, como um fato morfológico ou biológico usado para distinguir um grupo de seres de outro. Enquanto as categorias dos seres vivos são estanques e estáticas, a vida, e o limiar que ela instaura, desliza ao longo de toda uma escala. Em Pasteur, o limiar instaurado pela noção de vida é traçado pela dissimetria molecular. Para ele:

Os produtos essenciais da vida são dissimétricos. A dissimetria parece ser uma necessidade de constituição das moléculas que foram edificadas sob a influência da vida. No momento da elaboração dos princípios imediatos da vida, uma força dissimétrica está presente. (Pasteur, 1922, t.7: 656)

Este fato diz respeito às condições mais escondidas da vida e, de acordo com as análises da dissimetria molecular e da fermentação, somente a conciliação do ato químico com o ato vital poderia esclarecer. A idéia de vida como germe inaugura um saber que opera um deslocamento importante na maneira de conhecer: o deslocamento do mundo macroscópico para o mundo dos infinitamente pequenos. Os micróbios entram nas leis gerais da vida e de suas manifestações nas espécies superiores, vegetais e animais. Estão 
submetidos às leis gerais da vida do mesmo modo que as espécies superiores (tanto vegetais, quanto animais). Desta forma, a idéia de vida rompe com uma racionalidade cujos princípios básicos estão calcados numa hierarquia que desconsiderava a importância destes seres no universo. Para Pasteur, a única diferença entre os organismos microscópicos e os macroscópicos consiste na rapidez das variações dos micróbios, em oposição à lentidão das variações nos seres visíveis a olho nu. ${ }^{38}$

À vida como objeto de pesquisa correspondem novas formas de saber. O surgimento da microbiologia não é o resultado do aparecimento de novas técnicas - microscópicas - mas de uma mudança que assiste, nesse mesmo instante, ao nascimento da biologia através da configuração deste novo objeto que é a vida. As mesmas condições, que permitiram a constituição da biologia, permitiram o surgimento da microbiologia. Tais condições são dadas pela possibilidade de analisar a vida, seja em seres grandes seja em microscópicos: "Os infinitamente pequenos têm um papel imenso no universo, e o desaparecimento das espécies microscópicas levaria todas as outras a uma ruína comum" (Pasteur, 1922, t.2: 653). A possibilidade de analisar este novo objeto deve-se a uma mudança no olhar que passou a perscrutar a vida. Mas esta mudança não se deve à utilização do microscópio. $\mathrm{O}$ microscópio não pode ser considerado a causa desta mudança; ele é apenas um instrumento. Como todo instrumento, o microscópico é a aplicação prática de uma concepção abstrata. Mesmo que aumente o poder de resolução dos sentidos, e esta é a sua função, o saber produzido através dele depende, necessariamente, de uma transformação no nível teórico-conceitual. Não basta ver um corpo até então invisível para transformá-lo em objeto de análise.

Como explicita Jacob, quando Leeuwenhoek (1632-1723) contempla, pela primeira vez, no século XVII, uma gota d'água no microscópio, ele vê um mundo desconhecido, porém não estabelece nenhuma relação entre os seres microscópicos e o resto do mundo. Isto porque, para que um objeto seja acessível à análise, não basta aperceber-se dele. É preciso também que uma teoria esteja pronta para acolhê-lo. Ao ser visto, o microorganismo transformase, no século XIX, em um dado sensível que tem seu suporte numa idéia, ou seja, transforma-se num objeto da ciência. Podemos afirmar que aquilo que Pasteur observava ao microscópio - bastões, traços etc. - são signos cujo

\footnotetext{
${ }^{8}$ Cada cultura de um micróbio, com a duração de 24 horas, representa números imensos de gerações sucessivas, enquanto nos seres mais elevados são necessários, para completar tais números de gerações, milhares de anos.
} 
sentido o pensamento tem de decifrar como uma realidade articulada com a vida e que tem vida.

Enquanto objeto de conhecimento, o microorganismo não é um objeto já dado, a ser apreendido pelo observador através do microscópio; ele é produzido pelo saber, através de certos procedimentos que reúnem a observação pelo microscópio, técnicas variadas de experimentação (cultura, por exemplo) e métodos oriundos de regiões científicas diferentes (a física e a química). Sem dúvida, o bacilo pastoriano existe, e não pode ser reduzido ao resultado do aperfeiçoamento de técnicas experimentais, uma vez que as condições de possibilidade da concepção de microorganismo ultrapassam a prática. Tais condições dizem respeito a uma transformação na relação entre o conhecimento e seu objeto, a qual corresponde à entrada dos corpos inorgânicos, e das ciências que os estudam, no processo das pesquisas biomédicas. $\mathrm{Na}$ compreensão deste objeto, o microscópio funciona como um olho auxiliar que aumenta a inteligência:

De onde provêm então todas estas misteriosas transformações? O exame feito ao microscópio de uma gota deste líquido que perdeu sua limpidez primitiva vai nos dizer. Espetáculo admirável! Seres com a forma de bastões vão e vêm, param e retomam seu movimento. Eles são simples ou reunidos em dois, três ou quatro e ainda mais. Eis uma cadeia de dois que se separam após uma espécie de esforço mais ou menos prolongado da parte de suas metades que se agitaram como para se separar em sua articulação (...). Eu compreendo porque o líquido é leitoso. O que nossos olhos, em sua impotência, chamam turvo leitoso, uma inteligência aumentada pelo microscópio nos faz ver que este estado é uma conseqüência da vida destes pequenos seres e de seu movimento através da massa líquida. (Pasteur, 1922, t.6: 30)

\section{VÍRUS-VACINA}

O conceito de vírus-vacina é importante em nosso estudo sobre a microbiologia, devido a seu caráter de condição de possibilidade de estabelecer interfaces com diversos aspectos biomédicos relevantes, como, por exemplo, as técnicas de isolamento e de cultura dos micróbios, a medicação química, a profilaxia das doenças infecciosas etc., que permitem relacionar medicina e biologia, pelo viés da pesquisa da vida microbiana. O vírus-vacina é o "vírus que causa a doença e não a morte, preservando da ação do vírus mortal, 
seguindo a lei geral da não recidiva das doenças virulentas”. O vírus-vacina é um micróbio que "está apenas modificado em sua vitalidade" (Pasteur, 1922, t.6: 339,341$)$.

A idéia de vírus-vacina é decorrente da idéia de micróbio atenuado: "Os micróbios atenuados da cólera das galinhas podem se reproduzir por culturas sucessivas, conservando suas atenuações próprias" (Pasteur, 1922, t.6: 341). Pasteur propõe o termo vacina, em 1881, em homenagem a Jenner (1749-1823), estabelecendo, contudo, uma ruptura entre os produtos naturais e os produtos de laboratório, introduzindo uma nova idéia científica, a partir da idéia de que a vacina, para Jenner, é um vírus que produz uma doença benigna; uma vez contraída, ela preserva de uma doença mais grave, freqüentemente mortal, que é a varíola. A vacina de Jenner não é um produto de laboratório, é um produto natural; ela provém de uma doença própria da vaca e do cavalo.

Nesse caso, a vacina baseava-se no princípio de que a doença animal, contraída pelo homem sob uma forma benigna, o protegia dos ataques da doença humana. Mas a vacina de Pasteur supõe a noção de vírus-vacina, isto é, a identificação de microorganismos patogênicos, específicos de uma doença e, sobretudo, a idéia de atenuação da virulência dos micróbios patogênicos, estabelecida juntamente com as técnicas de atenuação, que permitem o preparo da vacina: "Vocês sabem como podemos preparar diferentes vacinas de carbúnculo e da cólera das galinhas, como podemos ir da virulência mínima a uma virulência que mata $100 \%$, passando por todos os intermediários" (Pasteur, 1922, t.6: 353).

A cultura dos organismos microscópicos serviu de guia de estudo para estes organismos. A necessidade da cultura deve-se, em Pasteur, à busca da causalidade que será justificada pela afirmação da presença dos germes e pela busca de um agente da doença e de contágio: "Para afirmar que um organismo microscópico é agente de doença e de contágio, é necessário submeter o organismo ao método das culturas sucessivas fora da economia" (Pasteur, 1922, t.6: 112). Do ponto de vista das técnicas de atenuação, a cultura também se coloca como de maior importância, na medida em que os meios de cultura exercem influências sobre as propriedades dos vírus cultivados, seja para fazer a atenuação, seja para aumentar a virulência:

Os trabalhos do meu laboratório estabeleceram que os vírus não são todos entidades mórbidas, que eles podem afetar formas e sobretudo propriedades fisiológicas múltiplas, dependendo dos meios onde estes vírus vivem e se multiplicam. Em conseqüência, e visto que a virulência 
pertence às espécies vivas microscópicas, ela é essencialmente modificável. Podemos enfraquecê-la, exaltá-la, e cada um destes estados é suscetível de ser fixado pela cultura. Um micróbio é virulento para um animal quando ele tem a faculdade de pulular em seu corpo como um parasita e aí provocar, regenerando, desordens que podem levar à doença e à morte. (Pasteur, 1922, t.6: 531)

Formados de um micróbio especial de "extrema pequenez", os vírus podem ser multiplicados por culturas artificiais fora do corpo dos animais. Desta forma, Pasteur tenta diminuir a virulência por meios racionais, o que confere a seu método um caráter inovador: fundamentar-se na idéia da existência de vírus-vacinas cultiváveis à vontade que podem ser multiplicados ao infinito, no intervalo de algumas horas, sem recorrer ao sangue carbunculoso. Podemos agora compreender, do ponto de vista conceitual internalista, como Pasteur foi conduzido ao estudo das doenças virulentas, correlacionando domínios de saber, até então independentes entre si, através dos seguintes procedimentos:

1) Estudo de cristalografia: afirmação da existência de uma barreira entre os produtos da natureza viva e os da natureza inanimada, entre os reinos animal e vegetal, de um lado, e o reino mineral, de outro. Estabelecimento desta dicotomia a partir da dissimetria molecular.

2) Estudo da fermentação (análise do ácido paratartárico numa de suas combinações moleculares): afirmação de que, nesta combinação, surgiria a fermentação e que ela seria produzida por um organismo vivo, microscópico, que se alimenta das moléculas do ácido tartárico destrógiro e não levógiro.

3) Estudo da vida: afirmação de que a vida não produz corpos simétricos e de que um organismo vivo destrói, num corpo composto de duas substâncias dissimétricas, somente uma destas substâncias, e não a outra. Introdução do estudo molecular em fisiologia, fornecendo uma base para o estudo das doenças virulentas.

Este ensaio sobre a noção de vida na obra de Pasteur restringe-se à delimitação conceitual de algumas noções que se estabelecem no século XIX. Ele sequer tenta dar conta, ainda que parcialmente, do problema da mudança da base do procedimento de classificação que passa a se realizar a partir de funções, e não mais de considerações morfológicas. $\mathrm{O}$ interesse deste estudo desenvolveu-se sem estabelecer relações políticas, econômicas ou sociais ligadas às práticas institucionais, como poderia ocorrer. Estes são, simplesmente, os limites de um recorte muito estreito aqui realizado. Tal delimitação não quer 
dizer, como poderia parecer, que o nível da prática deva ser desvalorizado; também não quer dizer que a questão do vitalismo e do valor atribuído à vida como princípio explicativo e de ação não deva ser politizada.

O objetivo desta pesquisa era mesmo fazer uma análise internalista e conceitual em que somente certos aspectos da ciência fossem considerados. Trata-se, apenas, da tentativa de explicitar, até certo ponto, a importância da noção de vida, considerada em escala micro, como ato vital ou força vital, visto que tal noção permite compreender o vitalismo de Pasteur, fazendo com que vitalismo e cientificidade não sejam, nestes termos, incompatíveis entre si. 



\title{
6 \\ Vitalismo e Constituição da Biologia segundo Jacob, Canguilhem e Foucault
}

\begin{abstract}
A retomada do vitalismo, que coloca a questão da natureza da vida e suas determinações em termos de força vital, é correlata do surgimento, no início do século XIX, do conceito de vida e de uma nova região de saber, a das ciências da vida. Num aparente paradoxo, este tema, que afirma a necessidade de um princípio irredutível ao domínio físico-químico para explicar os fenômenos vitais, reaparece vinculado ao estudo da vida como objeto empírico que pode ser experimentado. Sua análise é um importante ponto a ser pesquisado no estudo da constituição da biologia. Quanto a isto, contudo, não há nenhum consenso.

De acordo com Jacob, a noção vitalista de vida como força vital é que faz com que a biologia, no momento de sua constituição - início do século XIX -, não seja um braço menor da física ou da química e apresente uma especificidade própria às ciências da vida. Com o conceito de hereditariedade e com a biologia molecular, se reconhece a unidade dos processos físico-químicos no nível molecular da vida. Isto significa que o vitalismo perde inteiramente sua função; na realidade, o próprio conceito de vida deixa de ter um valor operatório para o conhecimento. Como afirma Jacob (1983: 299-300), "De fato, desde o nascimento da termodinâmica o valor operatório do conceito de vida diluiu-se e seu poder de abstração diminuiu. Atualmente, não se interroga mais a vida nos laboratórios. Não se procuram mais seus contornos”.

Entretanto, Canguilhem mostra que há, no conhecimento da vida, fenômenos que a mantêm afastada de qualquer conhecimento da física e da química, uma vez que conhecê-la depende de uma interrogação necessária sobre a possibilidade da doença, da morte, da monstruosidade, da anomalia
\end{abstract}


e do erro, constitutivos de seu objeto. A vida e a morte jamais são, em si mesmas, problemas de física. Letal ou não, uma mutação genética não é para o físico nem mais nem menos do que a substituição de uma base nucleica por uma outra. Mas, nesta diferença, o biólogo reconhece a marca de seu próprio objeto. Mesmo tendo se desenvolvido através da pesquisa dos mecanismos físico-químicos, a partir da constituição da química das células e das moléculas, e através da utilização de modelos matemáticos, o conhecimento da vida não pode se separar do problema da especificidade da doença e do limiar que ela determina para todos os seres naturais (Canguilhem, 1970b). Daí a importância epistemológica do vitalismo para as ciências da vida.

Porém, como comenta Foucault, isto não quer dizer que o vitalismo seja verdadeiro nem que deva constituir a insuperável filosofia dos biólogos, mas que teve e continua tendo, na história da biologia, um papel de indicador teórico de problemas a resolver - o que constitui a originalidade da vida sem que ela constitua um domínio independente da natureza - e de indicador crítico das reduções a evitar aquelas que tendem a fazer desconhecer que as ciências da vida não podem se abster de uma certa posição de valor. Trata-se de uma posição que marca a conservação, a regulação, a adaptação, a reprodução etc. Tal posição é "mais uma exigência do que um método, mais uma moral do que uma teoria" (Canguilhem apud Foucault, 2000: 363).

O tema da retomada do vitalismo pela ciência do início do século XIX é um ponto importante na análise da história das ciências da vida. Para Jacob, bem como para a epistemologia de Canguilhem - para a qual o valor operatório dos conceitos e a recorrência são metodologicamente prioritários na análise histórico-filosófica -, o vitalismo é constitutivo do conceito de vida em sua especificidade de objeto biológico e empírico, para cujo conhecimento será buscado, a partir do final do século XVIII, algo invisível e mais fundamental. Como explica Jacob, o recurso a um princípio vital decorre da atitude da biologia, da necessidade de separar os seres das coisas e de fundar esta separação não na matéria, cuja unidade é reconhecida, mas nas forças. Neste caso, o vitalismo é considerado como aquilo que funciona como fator de abstração, a noção de vida desempenhando um papel preciso no saber. A vida é aquilo que se investiga no animal ou na planta, é o objeto da análise. É esta fração de desconhecido que faz com que o organismo seja diferente da coisa e a biologia da física.

Contudo, o papel atribuído ao tema do vitalismo na história da constituição da biologia é diferente nas diversas abordagens históricas das ciências 
da vida. Apesar de muitas coincidências, como as críticas às histórias das idéias, as descontinuidades históricas, o privilégio da análise conceitual, os documentos analisados, é surpreendente a diferença do valor conferido a este tema pela epistemologia de Canguilhem e pela história de Jacob, por um lado, e pela arqueologia de Foucault, por outro.

Enquanto Canguilhem e Jacob explicitam o valor histórico da noção de vitalismo como operador de conhecimento na biologia e sua função na determinação da especificidade das ciências da vida, Foucault afirma serem ambos apenas efeitos de superfície de acontecimentos arqueológicos que se situam num nível mais profundo. Embora relevando os mesmos aspectos apontados pela epistemologia nas análises do surgimento da biologia - como a inexistência do conceito de vida até o final da época clássica, o papel constitutivo das estruturas visiveis na constituição dos saberes nesta época, o papel das funções invisíveis do organismo nos saberes da vida -, para Foucault, o vitalismo tem o valor apenas de efeito de superfície que diz respeito a uma camada mais fundamental do saber, a episteme.

Como tal, para a arqueologia, conforme afirma Foucault, em As Palauras e as Coisas o vitalismo não permite esclarecer os princípios de organização dos saberes, não tendo, por isto, importância explicativa.

Vê-se como, fraturando em profundidade o grande quadro da história natural, alguma coisa como uma biologia vai tornar-se possível; e como também poderá emergir nas análises de Bichat a oposição fundamental entre a vida e a morte. Não se tratará do triunfo, mais ou menos precário, de um vitalismo sobre um mecanismo; o vitalismo e seu esforço para definir a especificidade da vida não são mais que os efeitos de superfície desses acontecimentos arqueológicos. (Foucault, 2002a: 319)

A questão do vitalismo versus mecanicismo é, deste modo, um debate que se passa num nível que não diz respeito à configuração arqueológica do saber sobre a vida - da história natural ou da biologia - nem das condições de possibilidade de sua existência, alvos da arqueologia. Porém, apesar de Foucault se posicionar negativamente quanto à sua relevância nas análises arqueológicas, não escapa de a eles referir-se. Não, propriamente, para rejeitar as explicações da epistemologia, mas, como disse, para situar sua pesquisa num nível diferente de análise. Neste nível, a análise não se restringe à cientificidade das ciências da vida, mas as relaciona com outras ciências e com a 
filosofia, para explicar o aparecimento do conceito de homem, das ciências humanas e do antropologismo na modernidade. As condições de existência da biologia colocam-se em termos de uma nova configuração geral do saber irredutivel às ciências. Ao abandonar o espaço plano do quadro bidimensional das identidades e diferenças entre as representações da época clássica, o saber penetra no interior do espaço tridimensional do volume do corpo, estabelecendo a divisão entre o vivo e o não-vivo, entre a vida e a morte.

Para a arqueologia, o que importa é explicar as mutações que permitirão a radicalização da divisão entre o orgânico e o inorgânico e que possibilitarão ao saber contornar o espaço ideal da representação, estabelecendo outra forma de saber. Sua nova configuração funda-se não mais no olhar de superfície - da estrutura visível a ser ordenada no quadro -, mas num outro tipo de olhar, o de profundidade, que busca, no interior do corpo vivo, o elemento a ser classificado. Não é a oposição do mecanicismo ao vitalismo que importa, mas a do orgânico ao inorgânico, pois é esta última que, ao se tornar fundamental, impõe uma outra divisão, num outro nível e num outro espaço.

Pallas e Lamark formulam esta grande dicotomia, com a qual vem coincidir a oposição entre o ser vivo e o não-vivo (...). O orgânico torna-se o ser vivo e o ser vivo é o que produz, crescendo e reproduzindo-se; o inorgânico é o não-vivo, o que não se desenvolve nem se reproduz; é, nos limites da vida, o inerte e o infecundo - a morte. E se se mistura à vida, é como aquilo que nela tende a destruí-la e a matá-la. (Foucault, 2002a: 319)

Portanto, ao vitalismo é atribuído não só o valor de erro a ser abandonado, como nas histórias da ciência em geral ou histórias das idéias, mas o valor, por um lado, de conceito operatório, como na epistemologia francesa e na história de Jacob; por outro, o valor de efeito de uma superfície correspondente à camada mais profunda dos saberes empíricos, como na arqueologia. A questão que coloco é: como análises, que têm tantos pontos em comum, como as de Jacob e Foucault, se distanciam tanto com relação ao papel do vitalismo em suas pesquisas? Como explicar os diferentes valores atribuídos ao vitalismo nestas análises da constituição da biologia?

O objetivo deste ensaio é discutir o valor metodológico do vitalismo na construção do conceito moderno de vida e na história da constituição da biologia, a partir da hipótese de que, ao se oporem ao positivismo das histórias das idéias, as teses epistemológica e arqueológica não se contradizem, mas 
se situam em níveis filosóficos diferentes, ${ }^{39}$ complementando-se. Tal hipótese funda-se nas noções de ciência e de saber como objetos da arqueologia. É neste sentido que, em Arqueologia do Saber - livro elaborado quando Foucault não está mais envolvido com a questão do surgimento do conceito de vida e da biologia, para explicitar questões metodológicas levantadas pelo Círculo de Epistemologia ${ }^{40}$-, ele faz uma consideração muito elucidativa sobre o nível em que se situam as análises arqueológicas realizadas em O Nascimento da Clínica e em As Palavras e as Coisas. Ao se perguntar se a arqueologia se ocupa das ciências, se ela não é, afinal, uma análise dos discursos científicos, Foucault afirma que aquilo que a arqueologia tenta descrever não é a ciência em sua estrutura específica, mas o domínio, bem diferente, do saber.

Se a arqueologia trata do saber em sua relação com as figuras epistemológicas e as ciências, pode também interrogar o saber numa direção diferente e descrevê-lo num outro feixe de relações. A orientação em direção à episteme foi a única explorada até aqui, porque, por um gradiente que caracteriza nossa cultura, as formações discursivas não cessam de se 'epistemologizarem'. É interrogando as ciências, sua história, sua estranha unidade, sua dispersão e suas rupturas, que o domínio das positividades pode aparecer; é no interstício dos discursos científicos que a arqueologia pode atingir o jogo das formações discursivas. Por episteme, conceito que causa tantas controvérsias entre os especialistas em seu pensamento, bem como em seus adversários, Foucault entende o seguinte: o conjunto das relações podendo unir, numa época dada, as práticas discursivas que dão lugar a figuras epistemológicas, às ciências, eventualmente a sistemas formalizados; o modo segundo o qual, em cada uma destas formações discursivas, situam-se e operam as passagens à cientificidade e à formalização; a repartição destes limiares, que podem coincidir, subordinarem-se uns aos outros, ou apresentarem-se defasados no tempo; as relações laterais que podem

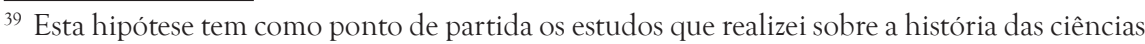
biomédicas e o conceito de vida, particularmente em Pasteur, Littré, Stahl, Van Helmont, Jacob, Canguilhem, Latour e Foucault. Acrescente-se a estes estudos a tese desenvolvida por Roberto Machado (2006), sobre os deslocamentos metodológicos operados por Foucault com relação à epistemologia de Canguilhem, de que há uma diferença entre o nível de análise da epistemologia, que se dirige à ciência para criticar o negativo da razão, e o da arqueologia, que se dirige ao nível da constituição dos saberes. Machado ressalta que a arqueologia nunca criticou, implícita ou explicitamente, a epistemologia; mas, mesmo respeitando sua especificidade, sempre procurou mostrar de que maneira a história epistemológica se encontrava na impossibilidade de analisar convenientemente o tipo de problema de que ela pode dar conta, as ciências humanas enquanto saberes.

${ }^{40}$ Note-se a esse respeito o artigo de Foucault (1994b) "Sur l'archéologie des sciences: réponse au Cercle d'Épistémologie”.
} 
existir entre as figuras epistemológicas ou as ciências na medida em que se originam em práticas discursivas vizinhas e distintas.

E, ainda, a episteme não é uma forma de conhecimento ou um tipo de racionalidade que, atravessando as ciências mais diversas, manifestaria a unidade soberana de um sujeito, de um espírito ou de uma época; ela é o conjunto das relações que se podem descobrir, para uma época dada, entre as ciências quando analisadas no nível das regularidades discursivas. Nesse nível, a análise não é uma maneira de retomar a questão crítica no sentido do direito e da legitimidade da ciência,

é uma interrogação que só acolhe o dado da ciência a fim de se perguntar o que é para uma dada ciência o fato de ser dada. No enigma do discurso científico, o que a arqueologia coloca em jogo não é o fato de seu direito de ser uma ciência, mas o fato de sua existência. (Foucault, 1969: 251)

\section{O VITALISMO NA MODERNIDADE}

O conceito de vida como força vital, que é oculta, mas, ao mesmo tempo, observável através de suas manifestações na e pela experimentação, é uma questão das ciências biomédicas na modernidade. No nível microbiológico, é a idéia de ato vital que permite relacionar objetos e métodos dispersivos provenientes da medicina, da biologia, da química, da física, da cristalografia e das técnicas de laboratório, reforçando a distinção entre o domínio do vivo e do não-vivo, como procede Pasteur.

No século XIX, a interpretação vitalista é rejeitada, mas, ao mesmo tempo, ganha espaço, na medida em que se associa à prova científica, ${ }^{41}$ como a de Pasteur, ${ }^{42}$ de que não existe geração espontânea, de que a vida não pode advir do não-vivo, do inanimado. Neste sentido, afirma-se uma concepção não mecanicista da vida, através da idéia da existência de uma força vital, que seria uma das condições mais secretas da vida, manifestadas no momento da formação de uma combinação de ordem vital. (Pasteur, 1922, t.7). A importância do vitalismo para a análise epistemológica das ciências da vida é enfatizada por Canguilhem e Jacob, que afirmam que o vitalismo foi indispensável para o surgimento da biologia, pelo menos num primeiro momento, visto que somente

\footnotetext{
${ }_{41}$ Em relação à questão da prova em ciências da vida, ver Salomont-Bayet (1986).

42 Jacob ressalta que, com maior freqüência, o vitalismo só intervém após a observação para interpretá-la, o que lhe conferiria, com mais certeza, estatuto de cientificidade.
} 
o vitalismo é, então, capaz de conferir às ciências da vida a originalidade do fenômeno biológico que é seu objeto.

Nessa época, parece inevitável a suposição da existência de uma força vital irredutível às forças da matéria inerte, capaz de conferir aos fenômenos da vida caracteres radicalmente diferenciados dos fenômenos físicos e químicos. Pois a noção de vida não mais diz respeito ao estudo das propriedades e formas de visibilidade dos seres vivos, como se fazia até o final do século XVIII, mas ao estudo daquilo que distingue o vivo do inanimado. O vitalismo é um conceito com valor cognitivo na condução da produção científica; ele permite interpretar as observações e as experiências. Jacob (1983: 99) o ressalta: "o vitalismo é tão essencial nos primórdios da biologia quanto era o mecanicismo na Idade Clássica”. Nessa época, quando o estudo dos astros e das pedras obedece às leis da mecânica expressas pelo cálculo, ou os seres são máquinas de que só se devem considerar as formas, dimensões e movimentos, ou escapam às leis da mecânica e não podem ser compreendidos pela ciência da época. Isto porque o funcionamento dos seres vivos só pode ser conhecido na medida em que reflete o que já se conhece a respeito do funcionamento das coisas.

Todos os cientistas optaram, então, pelo mecanicismo - interpretação pelas leis da mecânica expressas pelo cálculo - porque, até o final do século XVIII, não existe uma fronteira clara entre os seres e as coisas, e o vivo é estudado como um prolongamento contínuo do inanimado: toda a natureza é máquina, como a máquina é natureza; todos devem ser analisados e comparados através de seus elementos visíveis, de modo a formar um quadro de representações e uma linguagem bem feita, com uma sintaxe perfeita. Ao descrever o mundo vivo, Descartes (1596-1650) nega a necessidade da idéia de Deus, ou de razão, ou de um princípio desconhecido como princípio de movimento. Tal concepção aplica-se, claramente, à fisiologia, como vemos em Harvey (1578-1657), que faz do sangue e sua circulação um objeto a ser conhecido segundo as regras da hidráulica. A noção de máquina exclui qualquer potência oculta, qualquer finalidade interna ou imanente; os corpos se explicam apenas pela extensão e pelo movimento. $\mathrm{O}$ mecanicismo, apesar da insuficiência dos meios de que dispõe, representa a única atitude compatível com o conhecimento clássico; pois, as leis da física e da mecânica oferecem os fundamentos para a descrição das qualidades do não-vivo para serem aplicadas aos seres vivos.

A idéia clássica, explica Canguilhem, de que é uma força que move os seres vivos e de que esta força é a alma - anima -, leva os historiadores da ciência a explicarem o vitalismo do século XIX, sobrepondo-o ao animismo e à me- 
tafísica. Tal confusão deve-se a uma noção de vida que só pode ser conhecida a partir de uma essência abstrata, de uma alma, como a formulada por Stahl (1820-1903), que afirmava o vitalismo para explicar os seres vivos a partir de um processo diferente do da física e da química (apud Radl, 1988).

Littré (1801-1881) rejeita a concepção vitalista, confundindo-a com a noção animista da existência de uma alma, "propriedade vital do corpo, distinta dele, mas fazendo tudo nele” (apud Déchambre 1889, v.5). A alma age através das partes vivas do corpo, a partir das quais é possível conhecer o real e seus elementos; ela é um princípio imaterial, consciente, que planeja a máquina corpórea. A ação de um princípio imaterial sobre o corpo material deve-se à noção de existência de substâncias finas e grosseiras sujeitas à ação da alma. É ela que move o corpo vivo, nele imprimindo movimento, sua principal propriedade. O corpo não pode formar matérias: ele apenas reúne e se adapta, mediante a energia da alma, às necessidades da alma que lhe é imanente.

$\mathrm{O}$ animismo consiste, portanto, numa reação contra o mecanicismo cartesiano, contra a opinião de que tudo se faz quase, unicamente, pelas leis da mecânica, sem a ajuda de uma alma inteligente. Esta relação da noção de força da alma com o corpo é criticada, no século XIX, por aqueles que buscam a ciência submetida à prova, à experiência e à indução, como Déchambre (1889, v.5: 172): "Enquanto a existência da alma, enquanto substância imaterial adjunta ao corpo, é aceita, trata-se de demonstrar suas relações com o corpo. Este foi e é ainda um dos temas da metafísica. Este seria o primeiro, o mais importante da fisiologia”.

Stahl atribui à alma o princípio explicativo da vida. Tal princípio se opõe às leis da química, da física e da mecânica, para privilegiar, no ser vivo, os fenômenos do princípio vital que são mais os complexos e perfeitos. Littré critica estas explicações do vitalismo. Em sua opinião, elas constituem um sistema metafísico, cuja tendência viciosa de separar a matéria orgânica de suas propriedades, o afasta do estudo científico, que deve, ao contrário, reuni-los, através de leis químicas, físicas e matemáticas. Quando Stahl se pergunta em que consiste a vida, de que depende e em que relações e condições se fundamenta, por que e a partir de que conhecimento o corpo é designado como vivo, ele diferencia o corpo vivo da máquina. Muitos se ocuparam com este problema, afirma Stahl (apud Radl, 1988), mas não se chegou a um resultado definitivo, porque não se distingue mecanismo de organismo. Isto porque seria impossível, por simples inspeção ou descrição do relógio, por mais perfeita que fosse tal descrição, conhecer as leis físico-matemáticas de tal máquina ou 
compreender as relações das partes - números, rodas, dentes - e a sucessão do tempo medido, bem como seria impossível conhecer, através dessa inspeção, como se deve fazer ou reparar o relógio, seria impossível, ainda, conhecer, pela simples descrição física do corpo humano, como ele pode ser lesionado. ${ }^{43}$

Porém, de acordo com Jacob, o vitalismo não se confunde com o animismo que consiste apenas numa oposição à tendência para o materialismo, e não propriamente numa demonstração da existência de fenômenos específicos ao ser vivo, como o vitalismo no momento da constituição do conceito de vida.

\section{CRÍTICA ÀS HISTÓRIAS DAS IDÉIAS}

Para as histórias das idéias ou da ciência em geral, a ciência se desenvolve através de um leque de debates, que tenta reconstruir, para encontrar os vestígios de um conflito entre uma metafísica e uma ciência que já busca sua autonomia numa atitude positivista. Do ponto de vista positivista, a metafísica não constitui o pensamento positivo científico, pois se caracteriza pela predominância de abstrações e de explicações verbais na definição dos seres e dos fenômenos. Dependendo de sua maior ou menor proximidade com o estado positivo, tais explicações atribuem ao ser tanto o caráter metafísico de emanação de uma potência sobrenatural, quanto o de simples denominação abstrata positiva do fenômeno. O objeto metafísico é irredutivel ao científico. Esta é a posição de Littré e Déchambre, conhecidos também no Brasil, no século XIX,${ }^{44}$ por seus dicionários especializados em medicina, lingüística, história e filosofia. Neste sentido, o vitalismo é um erro que precisa ser afastado.

Littré (1878: 1.727) o define como uma "emanação direta das doutrinas metafísicas, que prevaleceram durante muito tempo sobre a alma, e da repugnância que tinham os bons espíritos em admitir que os fenômenos vitais pudessem se resolver em fenômenos físicos ou químicos". ${ }^{45}$ Neste caso, a força vital seria uma entidade pura, independente do corpo vivo, da matéria organizada, com propriedades determinadas seja por uma alma inteligente, como afirma Stahl (apud Déchambre, 1889), seja por uma arché subalterna, conforme pensa Van Helmont (1577-1644) (apud Radl, 1988).

\footnotetext{
${ }^{43}$ Note-se que Kant - que também discute o argumento do relógio para afirmar que a finalidade do ser vivo tem sua origem na própria idéia de organismo (apud Jacob, 1983) - refere-se a Stahl equiparando-o a Galileu e a Torricelli devido ao caráter experimental de seu trabalho (Kant, 1971).

${ }^{44}$ Littré é conhecido por seu Dictionnaire de Médecine, de Chirurgie, de Pharmacie, de l'Art Vétérinaire et des Sciences qui s'y Rapportent, já na 14a edição em 1878.

45 Tradução minha de todas as citações desta obra.
} 
Até o século XVII, os estudos sobre os seres vivos confirmavam que todas as forças da natureza estariam magicamente presentes nas propriedades do ser vivo, transformado, por um processo de atualização, num ser mais perfeito. A perfeição seria o princípio de explicação e dependeria de uma alma, de um princípio de pensamento e de vida ao mesmo tempo. A perfeição dos seres, suas propriedades e sua geração exigiriam um princípio desconhecido, uma força espiritual, uma psiché para executar as vontades divinas, pois não haveria nenhuma outra justificativa para a finalidade dos seres vivos. Para os positivistas, o que importa é afastar-se das crenças, das fantasias e das semelhanças, concebidas como máscaras sobrepostas aos contornos dos objetos, considerados, na época clássica, como representações. Isto equivaleria a transformar os seres vivos em objetos de ciência, concebidos como corpo-máquina. Daí a recorrência ao mecanicismo e ao animismo para explicar a vitória do vitalismo, no final do século XVIII.

Porém, os epistemólogos demonstram que o vitalismo não pode ser confundido com o animismo, nem com a metafísica, conforme fizeram os historiadores, uma vez que, ao rejeitar a elaboração de hipóteses sobre a essência dos fenômenos e privilegiar a descrição dos efeitos manifestados na experimentação, o vitalismo consiste no reconhecimento da originalidade do fato vital. Ele consiste, exatamente, na recusa de todas as teorias metafísicas sobre a vida - as fundadas no mecanicismo ou no animismo, bem como no reconhecimento correlato da especificidade do conhecimento biológico e sua independência com relação às ciências físico-matemáticas. Como tal, foi necessário à constituição da biologia na modernidade. Mesmo tendo sido posteriormente refutado, é constitutivo da passagem do conhecimento dos seres vivos para o da vida, da história natural para a biologia.

As histórias criticadas pela epistemologia e pela arqueologia consideram o surgimento das ciências da vida como decorrentes de uma nova curiosidade - a vida -, através de uma série de causas: observação, aperfeiçoamento técnico (microscópio), modelo de racionalidade da física, transferência do mecanicismo cartesiano para o domínio da vida, o interesse econômico pela agricultura, a curiosidade pelos animais e plantas exóticos, pelas grandes viagens etc. As ciências da vida teriam sido mecanicistas até o final do século XVII, marcadas pela química, e vitalistas, no final do século XVIII, opondo-se ao mecanicismo ou assimilando o animismo.

Canguilhem critica a acusação dos adversários do vitalismo, que levanta a hipótese de que este seria apenas uma transposição dogmática dos limites do 
mecanicismo e das leis físico-químicas. Neste caso, o mecanicismo cartesiano teria sido o primeiro instrumento a possibilitar uma transferência da racionalidade mecânica para a descoberta de uma outra, a do ser vivo, apesar de se ter também apresentado, mais tarde, como um obstáculo ao seu progresso. $\bigcirc$ desenvolvimento das ciências biológicas se descreveria como tendo dado um primeiro passo ao elaborar hipóteses mecanicistas, sob a influência de Descartes, assim se mantendo até o final do século XVIII, marcadas por uma química apenas esboçada. Temas do vitalismo teriam sido posteriormente privilegiados até se alcançar uma doutrina unitária, mais científica. $\mathrm{O}$ extraordinário progresso das ciências biomédicas se explicaria a partir de uma medicina tornada, finalmente, biológica e científica, e de uma biologia, finalmente - positiva, afastada da metafísica e da superstição pela razão e pela observação.

A afirmação de que a noção de vida só aparece na história do pensamento no início do século XIX é determinante nas críticas às histórias das idéias. Canguilhem, Jacob e Foucault afirmam que a história natural não pode se constituir progressivamente como biologia, pois, até o final do século XVIII, o conceito de vida não existe; mas apenas o de seres vivos a partir dos quais se ordenam as coisas, cuja série deve ser dividida em classes. Só podemos falar de vida na época clássica em termos de representação, de idéias abstratas, que constituem uma taxonomia. O ser vivo consiste numa localidade da classificação que faz parte do estabelecimento da grande ordem natural. Estes três autores se opõem às histórias das idéias, que atribuem à passagem da história natural para a biologia não o caráter de uma descontinuidade, mas o de um progresso do conhecimento, científico, linear, cumulativo, reconstituindo a história natural e seu passo imperfeito para o conhecimento, finalmente, positivo da vida.

Jacob e Canguilhem rejeitam estas histórias porque buscam o fio condutor das idéias, para traçar as etapas que se sucedem, através da extrapolação do presente sobre o passado, elegendo os predecessores das teorias em curso. Elas partem do pressuposto de que as idéias têm uma realidade ontológica e podem ser explicitadas, em uma linha contínua do tempo, por uma história factual. O precursor é, para a epistemologia, uma figura construída pelos cientistas que buscam legitimar, no passado, a novidade do presente que ainda não conseguiu ser compreendido.

O que a epistemologia busca não são as idéias acabadas. A história das ciências não pode ser confundida com seus resultados, visto que é em essência um discurso com pretensão à verdade, reunindo necessariamente 
proposições verdadeiras e falsas, pois a sucessão de impasses, tentativas e retomadas é imanente à produção da verdade científica. A história das ciências tem de analisar o erro, distinguindo o inerte e o ativo, o nocivo e o fecundo. A verdade se dá no interior do discurso, num processo cuja historicidade é constituída no movimento de verdade e erro. O elemento que exprime primordialmente sua normatividade é o conceito, cuja historicidade constitui o objeto da epistemologia.

\section{HistÓRIA NATURAL E BIOLOGIA}

A idéia do surgimento do conceito de vida, no final do século XVIII, e da impossibilidade de sua existência, até então, é central na história das ciências da vida tanto para a epistemologia como para a arqueologia.

A história natural, a zoologia ou a botânica consistem na observação e descrição dos seres vivos, para conhecer o que há de visível na natureza. $\bigcirc$ conhecimento não pretende penetrar numa profundidade invisível dos objetos, mas considerá-los, unicamente, em sua superfície, reduzindo-os àquilo que se oferece ao olhar, que se afirma como uma experiência sensível, uma percepção clara, em oposição à obscuridade das lendas, da tradição, da exegese e da interpretação de textos. $\mathrm{O}$ olhar funda-se na experiência sensível, descreve a forma da estrutura visível dos seres vivos, através da tradução em palavras daquilo que é visto, para estabelecer uma correlação entre o visível e aquilo que pode ser enunciado, como afirma Foucault em Nascimento da Clínica.

A descrição das propriedades essenciais ligadas à estrutura visível dos seres vivos - suas linhas, suas superfícies e seus volumes unidimensionais, que formam um conjunto de partes de uma planta ou animal - decompõe, analisa o todo, detalhando seus elementos constitutivos num quadro de essências abstratas enunciadas pelas palavras. Em As Palavras e as Coisas, Foucault explica que, na época clássica, as palavras representam as coisas por meio de uma linguagem, dando ao mundo a forma de um quadro, de uma ciência classificatória. A história natural deve se constituir de uma língua complexa e bem feita, como busca o cartesianismo, para denominar o visível por intermédio de um sistema de signos capaz de representar, ao mesmo tempo, as coisas e a própria capacidade de representar.

A história natural, bem como a filosofia, é um conhecimento analítico, baseado nas variáveis da descrição (a figura ou forma; o número ou quantidade; a proporção ou grandeza e a situação ou distribuição no espaço). A estrutura 
dos seres é a aplicação destas variáveis às partes que podem ser isoladas em um ser vivo. É pela estrutura que a história natural realiza um de seus objetivos fundamentais: nomeação do visível, através do reconhecimento de identidades e diferenças para estabelecer uma hierarquia com diferentes níveis classificatórios, por meio da comparação e ordenação dos seres.

$\mathrm{Na}$ época clássica, comparar é distribuir os seres neste espaço hierárquico de acordo com a estrutura de seus elementos. A comparação privilegia um ou vários elementos e relaciona todos os indivíduos segundo o caráter, marca própria do ser, que é a estrutura privilegiada para a análise. Os elementos que não são idênticos indicam a diferença que dará a marca da planta, seu caráter. Mais tarde, se estabelece uma heterogeneidade entre estrutura e caráter, que, até então, pertenciam ao mesmo nível de visibilidade. A partir desta heterogeneidade, o caráter poderá ser identificado de outra maneira; na modernidade, ele será estabelecido em termos de função do organismo, algo invisível que deve ser buscado no interior dos corpos com vida.

Descartes é analisado como o marco de uma nova positividade, uma nova concepção de saber. Foucault aponta, no cartesianismo, não só o fundamento da matemática e da física, mas, principalmente, e isto é essencial, o da história natural, da análise das riquezas e da gramática; analisa-o, também, para consolidar a idéia de uma descontinuidade da época clássica com relação à modernidade instaurada com Kant. No nível arqueológico, as descontinuidades são tratadas não em termos estritos de uma ciência clássica, como a história natural, e uma moderna que a substituiria, como a biologia, mas em termos da configuração geral do saber determinada pelas relações entre os diversos saberes, ciências e filosofia, considerados diferentes apenas em amplitude.

Os saberes clássicos, a ciência e a filosofia são conhecimentos analíticos que se passam no nível da representação, cujos objetos são as representações a serem ordenadas, nomeadas, classificadas. Eles correspondem ao projeto de construção de um método universal para produzir certezas perfeitas, através da perfeita ordenação das representações e dos signos. O saber dos seres vivos se constitui como análise da representação que se funda numa ciência universal da ordem, cujo instrumento é o sistema de signos que permite operar em termos de identidades e diferenças, e estabelecer um quadro classificatório; os seres vivos são classes como todas as coisas do mundo. A ordenação e a classificação rigorosas se fazem de acordo com as regras de subordinação dos caracteres numa unidade de plano, justapondo variáveis no mesmo espaço - o 
quadro classificatório - que é plano e bidimensional. Na história natural, suas variáveis devem ser percorridas pela linguagem e pelo olhar de superfície.

Para a arqueologia, é a possibilidade do quadro que define as estruturas mais gerais da episteme clássica, fundada na ordenação das coisas e dos seres, a partir das identidades e diferenças no nível da representação. O que torna possível, em seu conjunto, o conhecimento, na época clássica, é a maneira específica pela qual este se relaciona com a ordem das idéias e das coisas representadas pelas idéias no quadro. Só podemos falar de vida nessa época em termos de uma taxonomia. Daí o privilégio das árvores do conhecimento, das enciclopédias e dos mapas que rejeitam os signos e as similitudes infinitas.

Ao final do século XVIII, a representação perde o poder de fundar o conhecimento. Ao levantar a crítica à própria noção de representação e conduzir a investigação para as condições de possibilidade de todo conhecimento, a saber, da própria representação, Kant termina por explicitar um novo nível do conhecimento: o do objeto concreto e sintético. A noção de vida pode, então, aparecer, pois as coisas e os seres passam a ser considerados como obedecendo à lei de seu próprio devir. O conhecimento não se fará mais num quadro ideal, cuja superfície é plana e deve ser percorrida por um olhar de superfície, mas vai se voltar para o interior dos corpos empíricos, definidos por sua organização, agora determinada pela função, como em Cuvier. Na época moderna, órgãos e funções constituem um sistema integrado, com uma hierarquia interna, dada pelas funções que estabelecem relações sem nenhuma identidade visível.

Há um deslocamento, no final do século XVIII, das estruturas visíveis dos seres vivos para o invisível, enunciado pelo conceito de organização, que faz com que a determinação do caráter dependa da organização interna do vivo que escapa do nível da representação e remete o conhecimento para o volume, a espessura constituída de órgãos e funções, que desde então se chamará vida. Classificar não será mais ordenar os seres da natureza, exclusivamente, com base em critérios formais estabelecidos no nível da representação, mas relacionar o visível com o invisível no nível empírico. Todos estes pontos levantados por Foucault $(1963,1966)$ serão retraçados por Jacob.

Porém, ao estudar a época clássica, Foucault equipara os níveis científico e filosófico, considerando, ambos, como procedimentos de ordenação das representações, que constituem o estudo das relações entre as idéias; neste não há nenhuma referência a um outro nível, distinto, próprio para os objetos. Os três saberes clássicos voltados para as empiricidades - a história natural, a gramática e a análise das riquezas - se encontram estreitamente relacionados 
entre si e com a filosofia, visto pertencerem a um único solo epistemológico, o da ordem (e da medida que se reduz à ordem) e da representação. Para analisar objetos e submetê-los à combinatória, deduzindo sua ordem e sua medida, é necessário poder representá-los por um sistema de signos. Para extrair uma ordem, é suficiente, quando for possível, estabelecer a lei geral que permite agrupar objetos ou proposições, mesmo heterogêneos, fixar as classes e, nos limites desta ordem, percorrer o conjunto todo do domínio em que a lei se aplica. Para tanto, busca-se estabelecer um sistema de símbolos eficaz para a representação destes objetos ideais e suas inter-relações:

No racionalismo da Idade Clássica, o conhecimento baseava-se na concordância entre o objeto e o sujeito, entre as coisas e a representação que o espírito delas fazia. Com o aparecimento do que Kant chama um campo transcendental, o final do século XVIII aumenta o papel do sujeito na pesquisa sobre a natureza. (...) É preciso que os dados empíricos se articulem em profundidade, que se superponham em função de um elemento unificador que é condição de todo conhecimento, mas que está no exterior do conhecimento. É a vida que serve de referência, de transcendental, permitindo à consciência ligar as representações e estabelecer relações não somente entre os diferentes seres mas entre os diferentes elementos de um mesmo ser. É a vida que, no estudo do mundo vivo, permite alcançar verdades a posteriori e realizar uma síntese. (Jacob, 1983: 95)

Com Kant, o conhecimento não é mais uma análise de representações que relaciona as idéias entre si. Seu objeto é algo concreto que existe independentemente do sujeito que conhece. A modernidade surge a partir da busca das condições de possibilidade da representação. Com Kant, se estabelece no conhecimento a distinção entre o nível empírico e o transcendental, condição de possibilidade das sínteses possíveis. Os saberes podem, então, ser sintéticos, para dar conta dos objetos externos, ou analíticos, que não trazem nada de fora do pensamento.

Contudo, enquanto a epistemologia o afirma, verificando a depuração dos erros através de uma análise de conceitos e da produção de verdade na ciência, a arqueologia de Foucault procede pesquisando as condições de possibilidade da existência dos saberes e elidindo a questão da cientificidade. No nível arqueológico, as contradições entre diferentes teorias numa mesma época ou em épocas subseqüentes são efeitos de superfície do saber, que têm uma base homogênea, a episteme. O que faz surgir uma importante exigência metodoló- 
gica: é preciso reconstituir o sistema geral de pensamento cuja rede, em sua positividade, torna possível um jogo de opiniões simultâneas e aparentemente contraditórias. É esta rede que define as condições de possibilidade de um debate ou de um problema; é ela que é portadora da historicidade do saber.

\section{UM CONCEITO OPERATÓRIO}

A interpretação vitalista é diferenciada, pela epistemologia, do animismo e da metafísica, e considerada como uma oposição ao materialismo e à metafísica por sua exigência de experimentação. Ela tem, nesta história, implicações importantes para o reconhecimento da descontinuidade histórica que determina a especificidade do conceito de vida.

Pouco a pouco surge o objeto de uma ciência que estuda não mais os vegetais ou os animais enquanto elementos constituintes de certas classes entre os corpos da natureza, mas o ser vivo a quem uma certa organização confere propriedades singulares. Para designar esta ciência, Lamarck, Treviranus e Oken utilizam quase que simultaneamente o termo biologia. (Jacob, 1983: 94)

Em A Lógica da Vida (Jacob, 1983) o vitalismo aparece na história da hereditariedade, cujo objetivo é investigar de que modo objetos tornaram-se acessíveis à pesquisa científica e novos domínios de saber foram constituídos como ciência, através de uma análise conceitual, para determinar a natureza destes objetos, a atitude dos que os estudam, a maneira de observar, os obstáculos que sua cultura lhes coloca. Aí, demarcar as etapas do saber e suas transformações exige revelar as condições que permitem que os objetos e as interpretações entrem no campo do possível. A análise da questão da hereditariedade descreve as condições que, a partir do século XVI, permitiram o aparecimento sucessivo de estruturas que emergem na arquitetura do ser vivo, reveladas em camadas cada vez mais profundas. Trata-se de uma análise da maneira pela qual o conceito de geração sempre renovada, e que exige a intervenção de uma força externa, transforma-se na noção de reprodução, propriedade interna de todo sistema vivo; é a história de um objeto cada vez mais oculto.

Para Jacob, as transformações na forma de conceber a natureza dos seres vivos, sua estrutura, sua permanência ao longo das gerações são progressivas e têm uma historicidade própria. Sua abordagem deve se fundar nas diversas 
configurações da interrogação sobre a natureza, e não nas respostas, ainda que parciais, que são finalizações da elaboração científica da verdade, com as quais não é possível explicar o processo científico. ${ }^{46}$ Como na arqueologia, as formulações das questões científicas da vida devem ser analisadas a partir das diversas formas de relação entre a visibilidade, o olhar e o conhecimento, entre a maneira de olhar e seu objeto, e a partir dos diferentes modos pelos quais se enfoca a verdade.

$\mathrm{Na}$ investigação histórica de Jacob, é analisada a forma como objetos tornaram-se acessíveis à análise, como novos domínios se constituem como ciência, através da análise conceitual, para a qual "a importância de um conceito se mede por seu valor operatório, pelo papel que desempenha dirigindo a observação e a experiência" (Jacob, 1983: 18) na mudança da ordem em vigor, na reorganização do campo do possível e na modificação da maneira de conceber as coisas. Ao buscar os conceitos operatórios, Jacob considera que as idéias repudiadas e os obstáculos terão tanta importância quanto os da ciência atual; daí a grande diferença em relação à história dos precursores, visto não tentar reencontrar o caminho privilegiado das idéias e suas soluções, nem traçar a prefiguração do presente nas idéias passadas.

O vitalismo é um conceito operatório. Apesar de, mais tarde, vir a ser afastado como erro, é um erro que precisa ser analisado, pois é ele que conduz, num primeiro momento, a experiência e a elaboração de teorias sobre a vida e permite que se constitua o conceito de vida como algo irredutível ao nível físico e químico, conferindo à biologia uma especificidade própria. Por isto Jacob dedica tantas páginas à análise dos conflitos entre vitalismo, animismo, mecanicismo e materialismo. O valor atribuído ao vitalismo como conceito operatório, valor definido em função de seu papel na determinação da especificidade de uma ciência - a biologia - e em termos de uma disciplina, não pode ser o mesmo para a arqueologia.

\footnotetext{
${ }^{46}$ A pesquisa biológica de níveis sempre mais profundos do ser vivo não resulta, segundo Jacob, como vimos anteriormente, de um acúmulo de observações e experiências, mas expressa uma mudança mais radical que diz respeito a uma transformação na própria natureza do saber, correspondente a uma nova modalidade de considerar os objetos. Tal mudança deve-se mais a uma modificação na forma de olhar o vivo, de interrogá-lo, à qual a observação deveria responder, do que ao aparecimento de novas técnicas responsáveis pelo aperfeiçoamento do equipamento dos sentidos, pois, mesmo quando um instrumento aumenta o poder dos sentidos, ele nada mais é do que a aplicação de uma concepção abstrata.
} 


\section{EPISTEME E EFEITO DE SUPERFÍCIE}

Enquanto, no campo das ciências da vida, a epistemologia pretende analisar, através da recorrência e da análise dos conceitos operatórios, a racionalidade científica como processo de produção de verdades, a arqueologia de Foucault dirige-se à episteme e às rupturas que a delimitam sem intenção axiológica. Seu objetivo é estudar os saberes relevantes para o estabelecimento do modo de existência das ciências humanas, sua positividade, através de suas relações tanto com as ciências empíricas quanto com a filosofia moderna, para mostrar o aparecimento, na modernidade, de objetos empíricos - o trabalho, a linguagem, a vida - e sua relação com o homem e as ciências humanas. $\mathrm{O}$ estudo do surgimento do conceito de vida e da biologia se desenvolve para encontrar a forma que o saber assume na modernidade - na episteme moderna - a partir do estabelecimento de uma articulação da biologia com as outras ciências empíricas e a filosofia, cuja base seria sua vinculação com a linguagem mais atual da biologia, para traçar seu progresso, como propõe a epistemologia francesa.

Não devemos confundir a análise arqueológica, conforme observa Canguilhem (1967), com a busca de uma teoria geral subjacente, nem com um recorte comum a todas as ciências, visto que ela se volta para a episteme, tomando-a como um espaço de dispersão dos saberes, um campo aberto e, sem dúvida, indefinidamente, descritível de relações, onde se encontra o jogo simultâneo das configurações específicas e singulares dos saberes. Isto porque a episteme não pode ser identificada a um estado geral da razão, mas à complexa relação de deslocamentos particulares sucessivos; ela não é o espírito unitário de uma época, uma Weltanschaung.

No nível arqueológico, a história deve restituir as modificações que alteraram o saber e que tornaram possíveis os conhecimentos e o modo de ser daquilo que se sabe. Ela interroga os saberes de uma época no nível daquilo que tornou possível sua existência, para reconstituir o sistema geral de pensamento cuja rede, em sua positividade, possibilita o aparecimento de um determinado jogo de opiniões simultâneas e, aparentemente, contraditórias; pois, o que permite conhecer consiste propriamente neste espaço comum, o solo onde ocorrem os encontros de elementos dispersivos. A episteme é a rede de necessidades a partir da qual é possível pensar.

Em As Palavras e as Coisas, este nível é relacionado à cultura. Seu objetivo é analisar a experiência da ordem e mostrar não só aquilo em que esta 
experiência pode se tornar numa cultura como a nossa, mas a maneira como nossa cultura manifestou que havia ordem e que modalidades de ordem foram reconhecidas, para formar a base positiva dos conhecimentos e sua forma de desdobramento na gramática e na filologia, na história natural e na biologia, no estudo das riquezas e na economia política, enfim, na época clássica e na modernidade. Ao se dirigir à episteme, considerando os conhecimentos fora de todo critério referente a seu valor racional, Foucault pretende explicar as condições de possibilidade das formas do conhecimento do empírico e sua relação com a filosofia, tomando o lugar dos objetos da época clássica. É deste ponto de vista que Foucault afirma haver uma descontinuidade entre o estudo das empiricidades na época clássica e o dos objetos empíricos na época moderna.

Esta descontinuidade mostra rupturas essenciais, não apenas na região das ciências da vida, como faz a epistemologia - mas no espaço geral do saber ocidental. Através delas pode-se traçar a maneira pela qual cada positividade se modificou. É através da mutação dos seres empíricos, que determinam a positividade do saber da época clássica, e dos deslocamentos das positividades umas em relação às outras - da história natural em relação à análise das riquezas e à gramática geral, na época clássica e da biologia em relação à economia política e à filologia, na modernidade - que Foucault mostra que, no início do século XIX, a episteme não é mais a das identidades e diferenças, das ordens não quantitativas, da caracterização universal da taxonomia geral e da mathesis universalis.

No nível arqueológico, o aparecimento, na modernidade, da biologia e do conceito de vida corresponde à própria possibilidade da constituição dos saberes empíricos - não apenas a biologia, mas igualmente, a economia política e a filologia - bem como à possibilidade do pensamento crítico transcendental, com Kant. Trata-se de uma reordenação do saber, uma nova forma de relacionar o olhar e a linguagem, coetânea do desaparecimento de um tipo de positividade determinada pelo privilégio da análise da estrutura visível. Com a introdução, no pensamento, do nível empírico, o objeto do saber é uma coisa concreta que independe da representação. A representação permanece no exterior dos objetos empíricos - a vida, o trabalho e a linguagem -; resulta dos objetos empíricos e se efetua no homem como produto de sua consciência que corresponde mais ou menos claramente às coisas empíricas.

O espaço geral deste saber se constitui através do estabelecimento de analogias das funções nos corpos desdobradas a partir da aproximação das 
distintas organizações numa série temporal. Na modernidade, a temporalidade do empírico abre espaço às organizações analógicas, do mesmo modo que a ordem abria, na época clássica, às identidades e diferenças sucessivas. A partir do momento em que o conhecimento das coisas faz com que elas se voltem sobre si mesmas, sobre sua própria história, e busca-se seu princípio de inteligibilidade interna, surge a noção de homem, no sentido das ciências do homem.

Esta ruptura no âmbito da ciência corresponde ao novo tipo de filosofia, iniciada com Kant, que opera o deslocamento da questão filosófica do conhecimento como representação para o problema da possibilidade de conhecer a priori os objetos empíricos, a partir de uma submissão necessária do objeto ao sujeito, do empírico ao transcendental. Ora, as ciências do homem estudam o homem enquanto ele se representa a vida na qual está inserida sua existência, a sociedade em que realiza o trabalho, a produção e o sentido das palavras, fazendo uma reduplicação dos saberes empíricos sobre a vida, o trabalho e a linguagem. Elas reduplicam as ciências empíricas e a filosofia. Foucault explica, através de uma arqueologia, a constituição das ciências da vida para esclarecer a constituição das ciências do homem na modernidade.

A aparente continuidade no nível das teorias científicas e dos conflitos teóricos não corresponde aos sistemas de simultaneidade, nem às séries de mutações necessárias e suficientes para circunscrever uma positividade, a forma do saber de uma época. O que permite fazê-lo é somente a circunscrição do espaço constituído pela episteme, a qual confere uma unidade necessária à dispersão dos saberes. É no nível da episteme que a arqueologia busca traçar continuidades e descontinuidades, situando-se, portanto, num nível de conhecimento mais profundo, ao qual correspondem efeitos de superfície como as ciências, as teorias, as idéias e os temas como o vitalismo que, enquanto tal, não precisam ser analisados. O nível arqueológico é o nível da positividade que define um campo onde podem, eventualmente, se desdobrar identidades formais, continuidades temáticas, translações de conceitos, jogos polêmicos.

É a positividade de um discurso, afirma Foucault, como o da história natural ou da medicina clínica, que caracteriza sua unidade através do tempo e além das obras individuais, dos livros e dos textos. Esta unidade não permite decidir o verdadeiro e o falso, quem raciocina com rigor, quem segue seus próprios postulados.

de Lineu ou de Buffon, de Quesnay ou de Turgot, de Broussais ou de Bichat, ela também não permite dizer qual destas obras estava mais próxima de um destino primeiro, ou último, que formularia do modo 
mais radical o projeto geral de uma ciência. Mas o que ela permite fazer aparecer, é a medida segundo a qual Buffon e Lineu (Turgot e Quesnay, Broussais e Bichat) falavam da "mesma coisa", colocando-se no "mesmo nível" ou na "mesma distância", desdobrando "o mesmo campo conceitual", opondo-se sobre o "mesmo campo de batalha"; e ela faz aparecer, em troca, porque não se pode dizer que Darwin fala da mesma coisa que Diderot, que Laennec continua Van Swieten, ou que Jevons responde aos fisiocratas. (Foucault, 1969: 166)

A positividade define um espaço limitado de comunicação relativamente restrito, pois está longe de se dirigir a seu devir histórico desde sua origem até seu ponto atual. Todos os elementos dispersos - obras, livros, textos que pertencem a uma mesma formação discursiva - não se comunicam, exclusivamente, pelo encadeamento lógico das proposições que avançam, nem pela recorrência dos temas, nem pelo encabeçamento de uma significação transmitida, esquecida ou redescoberta. Todas estas individualidades diversas se comunicam pela forma de positividade de seu discurso.

No nível da arqueologia, bem como no da epistemologia, a preocupação da análise volta-se para os fenômenos de ruptura, para a incidência das interrupções. Contudo, o estatuto e a natureza das interrupções pesquisadas na arqueologia, colocadas em termos de positividade, não são os mesmos que os da epistemologia. Por esta razão, os conteúdos das descontinuidades por elas traçadas são ora, exatamente, os mesmos, ora diferem em valor, mas se complementam. 



\section{7 \\ Filosofia, Ciência e Vida no Pensamento de Canguilhem}

Ser sujeito do conhecimento, se o a priori está nas coisas, se o conceito está na vida, é simplesmente estar insatisfeito com o sentido encontrado. A subjetividade é apenas então a insatisfação. Mas isto é talvez a própria vida.

Canguillhem (1970a)

objetivo deste estudo é bastante pontual: analisar a relação estabelecida por Canguilhem entre filosofia, ciência e vida, através da questão "uma ciência da vida é possível?", ${ }^{47}$ não no sentido das condições arqueológicas de possibilidade de sua existência, mas epistemológicas. Esta é uma questão relevante para a pesquisa do surgimento do conceito de vida e da biologia na modernidade.

A este respeito, considero importante diferenciar dois níveis de análise histórico-filosófica: o nível da epistemologia francesa - em que se situam as pesquisas de Canguilhem - e o nível da arqueologia de Foucault. $\mathrm{O}$ interesse pelas análises de Canguilhem deve-se não só às profundas coincidências e diferenças entre sua abordagem histórica e a de Foucault; ${ }^{48}$ deve-se, sobretudo, às importantes contribuições de Canguilhem para um pensamento crítico sobre este tema, pois há nele uma busca da essência da vida na ciência e na filosofia, através de um racionalismo próprio do vitalismo.

\footnotetext{
${ }^{47}$ Esta questão é tratada por Dagognet (1997) em termos de sua consistência e de seu estatuto de cientificidade.

${ }^{48}$ Como, por exemplo, a diferença apontada por Machado através do estudo do deslocamento operado pela arqueologia, em relação à epistemologia de Canguilhem, da ciência para o saber (Machado, 2006)
} 


\section{RACIONALIDADE CIENTÍFICA}

Antes de tudo, é preciso ressaltar um comentário de Paul Rabinow em A Vital Rationalist (1994) ao observar que Canguilhem ${ }^{49}$ é comparado por Althusser com os antropólogos da ciência em campo. Althusser (2002) $)^{50}$ afirma que novos caminhos foram abertos na epistemologia por Cavaillès, Bachelard e Vuillemin, e, na história das ciências, por Canguilhem e Foucault. A primeira novidade dessas pesquisas tem a ver com uma exigência elementar, no entanto, até o aparecimento desses autores, freqüentemente negligenciada:

o respeito escrupuloso pela realidade da ciência real. Os novos epistemólogos se parecem com os etnólogos, que fazem "pesquisa de campo": eles vão ver a ciência de perto, e não aceitam falar daquilo que ignoram, ou do que não conhecem senão de segunda ou terceira mão (infelizmente era o caso de Brunschvig), ou percebem de fora, isto é, de longe. Essa simples exigência de honestidade e de conhecimento científico, vis-à-vis a realidade de que se fala, subverteu os problemas da epistemologia clássica. (Althusser, 2002: 273)

A segunda novidade destas pesquisas, segundo Althusser, deve-se a uma outra exigência elementar:

Que é por direito impossível tomar uma simples crônica ou uma filosofia da história (ou seja, uma concepção ideológica da história, do progresso da história, do progresso da Razão, etc.) como a História. Aí também os novos historiadores da história fizeram pesquisa de campo. Eles estudaram detalhadamente, à custa de um enorme trabalho de pesquisa (porque tiveram que servir-se de documentos convenientemente desconhecidos, aqueles que seus predecessores se negaram a usar porque não lhes serviam para suas demonstrações (...). (Althusser, 2002: 274)

É verdade que Rabinow logo salienta que o pensamento etnográfico, que introduz a antropologia em história das ciências, como o de Latour, ${ }^{51}$ só aparece bem mais tarde, na década de 1980. O objetivo de Latour é não apenas corrigir, como os epistemólogos, franceses, uma compreensão positivista e

\footnotetext{
${ }^{49}$ Não somente Canguilhem, mas também Bachelard, Vuillemin e Foucault, que se distanciam do universalismo estático da filosofia a respeito da ciência (Rabinow, 1994).

50 Trata-se de uma afirmação feita por Althusser em "Apresentação de Louis Althusser", texto acrescentado ao de Pierre Macherey, A Filosofia de Georges Canguilhem: epistemologia e história das ciências, publicado originalmente em 1964. A tradução de ambos encontra-se no posfácio da $5^{\text {a }}$ edição de O Normal e o Patológico (Canguilhem, 2002).

${ }^{51}$ Ressaltem-se, a esse respeito, os trabalhos de Latour Give me a Laboratory and I Will Raise the World (1983) e Science in Action (1987).
} 
idealista de ciência como atividade unificada alcançando um entendimento cumulativo da natureza, mas também 'desconstruir' a própria idéia de ciência, afastando-se assim, inteiramente, de Canguilhem.

Esta referência a Althusser, indica que Rabinow concorda com a idéia de um movimento anterior, já presente em Bachelard, que atribui um novo papel à filosofia: analisar o desenvolvimento histórico das verdades, no próprio processo de sua produção, enfatizando a prática dos cientistas, e tomando a ciência, que é dinâmica e tem uma normatividade interna própria, em sua especificidade e pluralidade. Com efeito, a epistemologia de Bachelard apresenta o projeto de desenvolver o pensamento baseando-se no fazer científico. Tal projeto, no entanto, opõe-se ao empirismo evolucionista positivista, que domina as primeiras décadas do século XX; opõe-se à idéia de que a pesquisa científica consiste em ampliações do real sensível, compreendido como realidade objetiva, tal qual se apresenta aos sentidos.

Para Canguilhem, assim como para Bachelard, apesar de a filosofia ter perdido, no século XX, a autonomia - afirmação com a qual Foucault (1994a) concorda -, a filosofia, cuja exigência é "reabrir debates mais do que fechálos" (Canguilhem, 2002: 17), ainda tinha um trabalho importante a realizar. Trata-se da pesquisa epistemológica, que busca restabelecer a ordem do progresso conceitual, seu movimento, que só é visível depois do fato, cujo ponto culminante e provisório é a noção mais atual da verdade da ciência. Segundo o epistemólogo, as verdades são produzidas na prática da ciência; à filosofia compete analisar a pluralidade destas verdades em sua historicidade, enquanto afirma, sem legislar, sua normatividade (Canguilhem, 1994a). A ciência, que para Canguilhem é um discurso verificado num setor delimitado da experiência, é uma exploração da norma da racionalidade em atividade.

\section{CiÊNCIA, NORMATIVIDADE E INDETERMINAC̣ÃO DA VIDA}

Canguilhem, bem como Foucault, atacou o edifício da normalização, essencial para os procedimentos de uma ciência e uma medicina positivistas. $^{52}$ Ele o fez recolocando a questão do organismo como um ser vivo que não mantém uma relação de harmonia preestabelecida com o meio. É o sofrimento, não a mensuração ou o desvio padrão que estabelece o estado

\footnotetext{
$\overline{52}$ Rabinow (1994) o ressalta, e Dagognet (1997) observa incisivamente.
} 
patológico. ${ }^{53} \mathrm{O}$ normal é a normatividade (instauração de novas normas) que começa com o ser vivo, e com ele advém a diversidade.

François Dagognet (1997) analisa o argumento de Canguilhem, explicitando a unidade de sua obra, desde sua tese de doutorado em medicina em 1943, O Normal e o Patológico, até seus últimos escritos, pois, diante das profundas mudanças realizadas nas ciências da vida durante o século XX, a pesquisa epistemológica de Canguilhem, voltada para a vida e para o conceito, opera uma inflexão, sem, contudo, modificar-se em seu fundamento: o caráter histórico e normativo da ciência - fisiologia, biologia, anatomia patológica, medicina - e da própria vida. O importante é que, para avaliar a extensão deste fundamento invariável, é preciso, primeiramente, observar a inversão que a tese de Canguilhem realiza no pensamento sobre a saúde, na França. Até então, o ensino médico privilegiava o normal, a normalidade, considerando a doença um desvio de normas fixas, que seriam as constantes. A prática médica buscava estabelecer, cientificamente, estas normas, para seguir a teoria e trazer de volta ao estado de saúde, de normalidade, o organismo, através do restabelecimento da norma da qual ele havia se afastado.

Como explica Foucault, de Bichat a Bernard, da análise das febres à patologia do fígado e de suas funções, estava aberto um imenso domínio que parecia prometer a unidade de uma fisiopatologia e acesso à compreensão dos fenômenos mórbidos a partir da análise dos processos normais. "Essa patologia baseada na normalidade caracterizou, parece, durante muito tempo, todo o pensamento médico" (Foucault, 2000: 362). Mas para Canguilhem, o organismo é um ser vivo que não tem uma harmonia preestabelecida com o meio. A normatividade - a instituição de novas normas - é própria do ser vivo, é constitutiva da vida. A normalidade consiste, assim, na capacidade de adaptação, de variação, do organismo às mudanças circunstanciais do meio externo e interno que, por sua vez, é variável. A normalidade é a própria capacidade de normatividade. A doença, ao contrário da saúde, é uma redução a constantes.

Esta inversão realizada por Canguilhem faz com que aquilo que antes caracterizava a normalidade - normas estáveis, valores imutáveis, constantes -

\footnotetext{
${ }^{53}$ Em O Normal e o Patológico, explicita-se detalhadamente essa questão. Para o momento, destaque-se a seguinte afirmação: "no que se refere à afirmação de identidade do fenômeno normal e do fenômeno patológico correspondente, é claro que a intenção de Comte é negar a diferença qualitativa que os adeptos do vitalismo admitiam entre um e outro. Segundo a lógica, negar uma diferença qualitativa deve levar a afirmar uma homogeneidade quantitativamente exprimível. Provavelmente é essa a tendência de Comte (...). No entanto, é preciso reconhecer que os termos aqui utilizados, por serem apenas vaga e imprecisamente quantitativos, conservam ainda uma ressonância qualitativa" (Canguilhem, 2002: 33).
} 
caracterize a doença. O que caracteriza a saúde é a possibilidade de transcender a norma que define a normalidade momentânea; é a possibilidade de tolerar as infrações da norma habitual e instituir novas normas em situações novas. Por isto, não se pode conceber a patologia como uma unidade propriamente objetiva. A única unidade que podemos ter, que não é puramente objetiva, é a de um ser vivo, que é um corpo vivo em permanente relação com o meio - relação variável, com um meio variável. Dagognet caracteriza a pesquisa de Canguilhem como uma fenomenologia, uma busca da essência ontológica da doença, do corpo vivo e da vida, desenvolvida a partir das biociências, a começar pela medicina, onde há confluência de muitas ciências, por ele considerada uma arte. Ele ressalta o vitalismo declarado do pensamento de Canguilhem, quer dizer, a tese de que a vida é irredutivel a qualquer forma de conhecimento que não respeite sua especificidade - a normatividade e a indeterminação. ${ }^{54}$

Sem dúvida, o vitalismo coloca filósofos e cientistas numa posição desconfortável. Na atualidade, ele é considerado, de um modo geral, muito pouco provável. A ele associam-se a metafísica, o existencialismo e uma incompatibilidade com a ciência, principalmente com a biologia desenvolvida no século XX. O argumento vitalista, que fez circular tantas imagens, perpetuou tantos mitos e se enraizou nas filosofias menos rigorosas, é muito difícil de se sustentar. Contudo, Dagonet demonstra a consistência da presença de uma forma de vitalismo no pensamento de Canguilhem. Em consonância com sua argumentação, duas coisas precisam ser ressaltadas: em primeiro lugar, quanto àquilo que constitui a originalidade da vida no seio da natureza, seu papel de indicador teórico de problemas a resolver; em segundo lugar, seu caráter de indicador crítico das reduções, que devem ser evitadas, em termos da posição de valor a ser assumida pelas ciências da vida, conforme ressalta Foucault (2000).

Não se deve confundir o pensamento de Canguilhem com uma filosofia existencialista da vida. Rabinow é enfático quanto a isto. $O$ pensamento de Canguilhem não é uma filosofia da vida; seus ensaios históricos não podem ser considerados como uma filosofia que tenta fixar uma compreensão da vida num único sistema de conceitos, como a de Hans Jonas ou de Merleau-Ponty. É preciso concordar com a afirmação de Rabinow e de Foucault de que, apesar de ter tido o cuidado de não conduzir seu ensaios para um elogio do vitalismo,

${ }^{54}$ Conferir, a respeito do vitalismo de Canguilhem, o comentário de Foucault (2000) em A Vida: a experiência e a ciência. 
Canguilhem demonstra a presença constante de noções de valor - como preservação, regulação, adaptação e normalidade - no conhecimento científico da vida. Rabinow (1994) também mostra, em Canguilhem, a afirmação das noções de valor nas abordagens do cotidiano, pois, para ele é a vida, não o julgamento médico, que faz do normal biológico um conceito de valor, e não um conceito estatístico de realidade.

Em O Normal e o Patológico, Canguilhem mostra como o problema da especificidade da vida, tratado em termos de normalidade biológica, não pode se reduzir ao homem. Ele considera, ao contrário, que,

para um ser vivo, o fato de reagir por uma doença a uma lesão, a uma infestação, a uma anarquia funcional, traduz um fato fundamental: é que a vida não é indiferente às condições nas quais ela é possível, que a vida é polaridade e, por isso mesmo, posição inconsciente de valor, em resumo, que a vida é de fato uma atividade normativa. (Canguilhem, 2002: 96)

Canguilhem define normativo como qualquer julgamento que aprecie ou qualifique um fato em relação a uma norma, mas, para ele, esta forma de julgamento está subordinada, no fundo, àquele que institui as normas.

No pleno sentido da palavra, normativo é o que institui as normas. Eé neste sentido que propomos falar sobre uma normatividade biológica. Julgamos estar tão atentos quanto quaisquer outros para não sucumbirmos à tendência de cair no antropomorfismo. Não emprestamos às normas vitais um conteúdo humano, mas gostaríamos de saber como é que a normatividade essencial à consciência humana se explicaria se, de certo modo, já não estivesse, em germe, na vida. (Canguilhem, 2002: 96-7)

É importante notar os dois níveis diferentes em que se situa Canguilhem ao definir vida $;^{55}$ pelo menos duas ordens são investigadas nas análises das relações entre o conceito e a vida. A saber, a vida como forma - o vivo, le vivant - e a vida como uma experiência de um ser vivo singular que é consciente de sua vida - o vivido, le vécu. Para Canguilhem, a especificidade da humanidade reside não no fato de ser separada do resto da natureza, mas no fato de ter criado conhecimentos sistemáticos, conceitos e ferramentas para ajudá-la na luta pela vida.

\footnotetext{
55 Tanto Rabinow quanto Dagognet ressaltam esta diferença explicitando a dupla possibilidade do sentido de vida na obra de Canguilhem.
} 
Contra a possibilidade de considerar que argumentar em favor da vida, através da noção de normatividade vital, pode retirar o valor político da vida, permitindo até justificar ideais de eugenia (raciais etc.), deve-se lembrar Dagognet (1997: 12) ao enfatizar que, renunciando às idéias de ordem e progresso, Canguilhem privilegia um "Marx a oeste" e exige das sociedades exploradas que se libertem do opressor. Nesta perspectiva de luta, é, finalmente, a vida que desempenhará o papel de bússola, já que a matéria se perde, a técnica submetida à economia acaba com nossas riquezas e acumula dejetos e a ciência não pode mais exercer sua função reguladora. Convém, assim, mais do nunca, voltar-se para o vital, na base da liberdade, retirando o corpo do alvo do poder daqueles que pretendem governá-lo.

Canguilhem investiga a vida não só no nível fisiológico, do corpo, mas também no nível da instituição médica e de sua racionalidade, de cuja dominação é necessário que o corpo se liberte. Em ambos os níveis é a vida mesma a base de tudo. Como, para ele, a vida no nível da "organização universal da matéria” como forma é que controla a vida no nível da experiência do vivido, afasta-se toda a possibilidade do existencialismo em sua filosofia.

Dagognet marca a inspiração nietzschiana de Canguilhem, para mostrar que o epistemólogo funda a filosofia nas pesquisas da biologia e da medicina, mas as subordina à vida, da qual dependem em todos os sentidos. Fica claro, então, que a denominação de racionalista vital, conferida a Canguilhem por Rabinow e Delaporte (1994), ou a de filósofo da vida, formulada por Dagognet, só podem ser compreendidas a partir da noção de uma filosofia afirmativa da vida, no sentido da busca da expansão da vida, do aumento da intensidade da força. Não no sentido rejeitado por Foucault, do existencialista que caracteriza o antropomorfismo da modernidade.

A filosofia de Canguilhem acompanha a biologia e a medicina quando estas estavam em plena turbulência. Trata-se, no início de sua obra, de mostrar que as ciências da vida se subordinam à vida mesma. No final, o filósofo reconhece a importância e o progresso da medicina e da biologia, mas conta com a vida para impedir suas extrapolações mais perigosas. Nos dois casos, embora de modos diferentes, a vida é chamada a debelar ou a reduzir uma cientificidade que se arrisca na desmesura. A estreita relação que o pensamento filosófico de Canguilhem trava com a ciência conduz a uma questão de cunho epistemológico, que parece prévia à análise da consistência de sua argumentação - se a vida pode ser considerada objeto de ciência. O problema é que o objeto da ciência deve ser estável e objetivo, mas para Canguilhem, 
por um lado, o corpo instaura normas escapando assim de uma concepção estável, visto que nele há uma margem de inventividade; por outro lado, a vida é variação de formas e obedece às exigências do meio.

Em relação a tal questão, é interessante tomar alguns pontos do estudo de Dagognet que apresenta, traçando uma história das ciências da vida, vários obstáculos advindos tanto da biologia ou da medicina quanto da filosofia, que foram enfrentados por Canguilhem e que contestariam seu pensamento ou lhe retirariam a legitimidade. O primeiro obstáculo apontado é a noção de corpo vivo que instaura normas e escapa de uma concepção redutora, pois é necessário reconhecer no corpo vivo uma margem reativa de inventividade que nem a doença suprime. A vida não é estática, não é um conjunto fixo de leis naturais. Ela envolve, em qualquer forma que possa tomar, a autopreservação por meio da auto-regulação. Esta é a especificidade da vida da qual não se pode escapar. Esta é a idéia central de Canguilhem, reafirmada ao longo de sua obra; mas reavaliada à medida que a ciência vai evoluindo.

Sem dúvida, o esforço de Canguilhem de permanente revisão mostra um pensamento em exercício. Isto o torna riquíssimo, sobretudo porque ele se desenvolve durante uma verdadeira revolução da biologia - o surgimento da genética, no século XX. A um pensamento, cujo modelo é o do tribunal da história e que é ancorado na verdade mais atual da ciência, em sua historicidade, é indispensável o procedimento que Foucault chamará de prova modificadora de si, o que faz com que a filosofia não seja uma apresentação que simplifica e é unificadora nem um comentário.

Dagognet mostra a pertinência dos Cursos, em que Canguilhem discute a criação para rejeitar a tese dos teóricos da criação que a definem como resultado da aplicação de princípios ou regras operatórias preestabelecidos concepção tradicional da filosofia médica, pois a verdadeira criação só pode ser conhecida após sua manifestação. A vida resolve seus dramas ou conflitos à medida que acontecem e segundo as exigências do meio. Seria impossível saber inscrever, previamente, as soluções que a vida retém. $O$ ato original não é um cânon, é uma efetividade.

Dagognet dedica um capítulo inteiro de seu livro Georges Canguilhem: philosophe de la vie (1997) à questão da possibilidade de uma ciência da vida. É este seu argumento: a ciência se opõe, por definição, à idéia de um organismo que transcenderia as leis ou as constantes. Se a saúde quebra ou ultrapassa as próprias normas, tornando relativas as pretensas regularidades, tese de Canguilhem, em que sentido o trabalho do biólogo, que pretende apoderar-se das 
modalidades de exercício do vivo, seria científico? É este o problema: ou bem a ciência biológica é um logro - a despeito de suas análises, de suas mensurações e de sua aparelhagem - ou bem é preciso renunciar ao ponto de vista do epistemólogo. Coloca-se, então, a noção de objeto da ciência, formulada por Canguilhem (1997: 135):

Quando pensamos no objeto de uma ciência, pensamos num objeto estável, idêntico a si mesmo. A matéria e o movimento, regidos pela inércia, dão a este respeito toda garantia. Mas e a vida? Não é ela evolução, variação de formas, invenção de comportamentos? Sua estrutura não é histórica, tanto quanto histológica? A fisiologia tenderia então à história que não é ciência da natureza.

Qual seria o estatuto de uma ciência que encerra contradições? Primeiramente, como saber científico, deveria buscar o universal, mas naturaliza e objetiva um objeto que inclui a dimensão do subjetivo e o individual. Em segundo lugar, deveria buscar certezas, mas tem como ponto de partida incertezas e erros que podem fazer a ciência progredir, conforme mostra sua história, tais como os cometidos por Claude Bernard quanto à diabetes; ou, erros de experimentação em patologia, laboratório e cirurgia, inevitáveis para uma ciência, como a biologia, que não pode se reduzir a registrar o objeto.

A questão do estatuto da ciência e de seu objeto é recorrente na obra de Canguilhem e varia de acordo com o movimento da própria ciência:

Mas permanece a questão de base: se a fisiologia não se contenta com resultados e constatações obtidas pelos instrumentos, qual vai poder ser seu objeto? Em que ele consiste sabendo que não é possível recolocar em questão "a criatividade" que caracteriza a vitalidade? (Dagognet, 1997: $129-130)^{56}$

Canguilhem confirma a possibilidade das ciências da vida, desde que se reconheça a especificidade da vida, através da exposição de detalhes científicos que afastam a idéia de um corpo visto como um todo indeterminado. Mesmo quando surge a noção de dispositivo nucleico, a sua posição se mantém, afirma Dagognet, pois este se transforma com o meio, e a vida se debate com aquilo que a cerca e a ameaça. A patologia da segunda metade do século XX parece depender, cada vez menos, dos agentes exteriores ou os 'inimigos' que se infiltram de fora e mais das reações excessivas do organismo. Com isto, é necessário voltar ao corpo e a suas reações. Com todas as mudanças da gené-

56 Tradução minha de todas as citações desta obra. 
tica e da bioquímica, em que se inscrevem as ciências da vida, Canguilhem se pergunta, mais uma vez, se é preciso abandonar suas hipóteses e e a resposta é negativa.

Em Le Concept et la Vie (Canguilhem, 1966), é analisada a revolução na genética e na biologia molecular, a partir da história do conceito de vida. Tudo muda no século XX, principalmente, na segunda metade. E o principal ponto é a mudança de escala do conhecimento. Enquanto a astronomia aumenta seu domínio - o mundo solar, depois as galáxias - a biologia, ao contrário, o transforma em miniatura (não a célula, mas a bactéria, e, em seu interior, o cromossoma, o gene, a enzima etc.). Passa-se do macroscópico e da visibilidade para as estruturas hereditárias.

A biologia dispõe na célula reprodutora aquilo que tinha sido, até então, reservado para o corpo em sua totalidade, seguindo a evolução geral de todas as disciplinas experimentais, que é a mudança de escala.

Mudando a escala na qual são estudados os fenômenos da vida (...) a biologia mudou de linguagem; ela deixou de utilizar a linguagem e as concepções da mecânica, da física e da química clássicas, linguagem baseada em conceitos formados mais ou menos diretamente sobre modelos geométricos. Ela utiliza agora a linguagem da teoria da linguagem e a da teoria da comunicação. Mensagem, informação programa, código, instrução, decodificação, tais são os novos conceitos do conhecimento da vida. (Canguilhem apud Dagognet, 1997: 50)

Neste caso, o que está em jogo é a idéia de que, quanto mais se modifica o conhecimento daquilo que envolve a vida, menos se conhece aquilo que é envolvido. E Dagognet (1997: 50) esclarece:

Em suma, para falar de uma maneira comum, mais se muda o ornamento, menos se toca naquilo que ela encobria ou ornamentava. O filósofo pode então concluir que a noumenobiologia que ele havia desenvolvido não é discutida. A vitalidade não foi nem anexada, nem enfeudada numa outra além de si mesma; ela não cessa de se auto-regular.

Para o desenvolvimento da questão ora proposta, é interessante o resumo histórico que Dagognet faz dos obstáculos e necessidades que conduzem Canguilhem a um autoquestionamento e uma atualização de seu pensamento dividindo-o em períodos: no primeiro grande período, o médico e o fisiologista descreviam e classificavam tanto os seres vivos quanto as doenças (a nosologia). Depois, a anatomia e a fisiologia, auxiliadas pela físico-química instrumental, 
renovaram os conhecimentos; no domínio da patologia, o diabetes era definido como excesso de produção de glicose pelo fígado e, sem dúvida, a sua não utilização, o que conduz à sua eliminação urinária (a alteração quantitativa).

Finalmente, no século XX, a biologia não se dirige mais à vida e suas manifestações mais características (suas constantes), mas vai à sua fonte, pois, a partir de então, os funcionamentos fisiológicos e as doenças exteriorizam os determinantes incrustados no genoma, finalmente, explorado. E, no fundo, afirma Dagognet, se não cessamos de nos destruir e de nos enganar (a entropia inevitável), nós nos renovamos a cada instante; nós nos regeneramos. Num primeiro momento, a físico-química apreende este fenômeno em seu aspecto material, sempre presente; mas, num segundo momento, ele lhe escapa, porque isto significa uma informação que continua, instaurando uma ordem, constituída de uma seqüência nucleica regular ou de uma combinação individualmente especificada; a vitalidade não pára de se auto-regular.

Do mesmo modo que a física elétrica pode estudar uma corrente entrecortada enquanto tal, o especialista em comunicação vê nela outra coisa; ele vê uma mensagem (o telégrafo Morse). $\mathrm{O}$ mesmo acontece com a biologia: a materialidade apresentada conta menos do que aquilo que passa através dela. No século XX, a concepção de vida não reside mais na estruturação da matéria e regulação das funções. Ela corresponde a uma mudança de escala e espaço operada pelo deslocamento da mecânica para a teoria da informação e da comunicação. Contudo, de acordo com a nova concepção, o genoma não é uma simples seqüência de unidades ou de pedaços separados uns dos outros. Alguns comandam os outros (os operons), enquanto outros reprimem ou impedem (os repressores). A organização se impõe sobre as partes, o que explica os suprimentos, as correções ou as regulações. Mudou-se de escala, não de princípio. Transportou-se para o ínfimo aquilo que havia sido elaborado com relação às funções na fisiologia macroscópica. A descoberta da estrutura helicoidal (dupla hélice), de Watson e Crick, e a formulação do conceito de código genético como um sistema de informação também confirmam a tese de Canguilhem. O código e o meio - celular e extracelular - estão em constante interação.

Certamente, a mudança de escala - do macro ao microscópico - e a constituição da biologia genética, cujo modelo é a teoria da informação, da linguagem, impõem a Canguilhem uma revisão de seu pensamento. Suas noções de corpo e de vida, estabelecidas a partir da história epistemológica das ciências biomédicas, são associadas ao vivo concebido como matéria físico-química e 
como assegurando a mensagem e a manutenção do 'texto' das estruturas genéticas. Neste sentido, a vitalidade corresponde a um texto codificado, mas é a vida concreta individual que o realiza. A materialidade do vivo conta menos do que o fluxo que passa através dela. É esta matéria 'desmaterializada' que, do ponto de vista epistemológico, torna não só uma ciência da vida possível, mas também o vitalismo de Canguilhem.

Em suma, face à profunda mudança realizada nas ciências da vida, durante o século XX, a pesquisa epistemológica de Canguilhem, voltada para a vida e para o conceito, opera uma inflexão, sem, contudo, modificar-se em seu fundamento: o objeto da ciência deve ser estável e objetivo, mas o corpo instaura normas e escapa de uma concepção estável, pois nele se reconhece uma margem de inventividade; e, ainda, a vida é variação de formas e obedece às exigências do meio. Canguilhem funda sua epistemologia no estudo da biologia e da medicina, mas a subordina à vida propriamente dita, da qual depende, tanto no nível da prática quanto da teoria, em todos os sentidos. 
Parte III

Vida, Arqueologia e Genealogia 
Como pode ocorrer que o homem pense o que ele não pensa, habite o que lhe escapa sob a forma de uma ocupação muda, anime, por uma espécie de movimento rijo, essa figura dele mesmo que se the apresenta sob a forma de uma exterioridade obstinada? Como pode o homem ser essa vida cuja rede, cujas pulsações, cuja força encoberta transbordam indefinidamente a experiência que dela lhe é imediatamente dada?

Foucault (2002a) 


\section{8 \\ Formas de Investigação da Vida no Pensamento de Foucault}

Ao isolar a noção de vida na obra de Michel Foucault, verifica-se que ele a investiga em três momentos e de maneiras diferentes. Primeiramente, como objeto de saber, em suas pesquisas arqueológicas dos anos 60, nos livros O Nascimento da Clínica e As Palauras e as Coisas, onde são buscadas as condições da existência de saberes empíricos, como as ciências da vida que possibilitaram a constituição, a partir do final do século XVIII, das ciências do homem.

Em seguida, a vida é pesquisada como objeto de saber-poder, nos anos 70, na dimensão de uma genealogia das formas de relações de poder, a partir de Vigiar e Punir e História da Sexualidade 1: a vontade de saber e de cursos como Em Defesa da Sociedade (2002b) e Segurança, Território e População (2008a), proferidos em 1976 e 1978 respectivamente. Nesta dimensão, que é a de uma analítica do poder, as ciências biológicas constituídas a partir do século XIX são articuladas com outros campos de saber e de práticas. Esta articulação caracteriza as análises genealógicas como um estudo das relações de forças que incidem sobre a vida dos indivíduos e das populações, tomando-os como alvo, seja através da formação do poder disciplinar que se exerce sobre o corpo e a alma, seja através da constituição do biopoder. ${ }^{57}$ Tal incidência de forças só é possível, de acordo com a genealogia, no contexto da entrada da noção de

\footnotetext{
${ }^{57}$ Note-se a retomada, com a noção de biopoder, da idéia de fato biológico na concepção de ser humano: "biopoder, isto é, essa série de fenômenos que me parece bastante importante, a saber, o conjunto dos mecanismos pelos quais aquilo que, na espécie humana, constitui suas características biológicas fundamentais vai poder entrar numa política, numa estratégia política, numa estratégia geral de poder. Em outras palavras, como as sociedades ocidentais modernas, a partir do século XVIII, voltaram a levar em conta o fato biológico fundamental de que o ser humano constitui uma espécie humana" (Foucault, 2008a: 3).
} 
vida biológica no pensamento e na prática políticos. Ela é a resposta política ao aparecimento, no século XIX, de um novo objeto - a vida do homem como espécie.

Finalmente, a vida é investigada como obra de arte em sua genealogia do final dos anos 70, em seus livros História da Sexualidade 2: o uso dos prazeres (1984a) e História da Sexualidade 3: o cuidado de si (1984b), em cursos como A Hermenêutica do Sujeito (2004), Le Gouvernement de Soi et des Autres I (2008b) e Le Courage de la Verité: le gouvernement de soi et des autres II (2009), proferidos em 1982 e 1984 respectivamente, bem como em conferências e inúmeras entrevistas. Aí, o antigo tema do cuidado de si é ressaltado como um conjunto de experiências modificadoras do sujeito, cuja finalidade é estabelecer para si mesmo um modo de vida ético e estético ativo.

A obra de Foucault pode ser compreendida, conforme ele mesmo propõe retrospectivamente, como um projeto de investigação sobre o sujeito e a verdade. Neste caso, deve-se afirmar que as duas primeiras formas de investigação, a arqueologia e a genealogia do poder, são uma pesquisa dos modos de objetivação do sujeito pelos saberes e poderes modernos, e que a última forma consiste num estudo dos modos de subjetivação do indivíduo. Sua obra se define, então, como uma história das formas de problematização. Este projeto, como ele mesmo afirma, é uma genealogia do modo pelo qual um campo não problemático da experiência - conjunto de práticas familiares, aceitas sem questionamento e fora de discussão - torna-se problema, suscita discussão e debate, incita novas reações. Assim entendida, a história do pensamento é a história da maneira pela qual as pessoas começam a preocupar-se com alguma coisa, ficam ansiosas com algo, por exemplo, com a loucura, o crime, o sexo, a verdade (Foucault, 2001b).

Não se trata, entretanto, da investigação do comportamento passado das pessoas (que seria do campo da história social), nem das idéias em seus valores representativos (história das idéias), tampouco estão em jogo explicações causais. Seu objeto é o como e o porquê certas coisas que sempre foram negligenciadas até um dado momento histórico tornam-se objeto de preocupação, uma problematização, que é uma resposta dada a uma situação particular.

Mas temos que compreender muito claramente, penso, que uma problematização dada não é um efeito ou conseqüência de um contexto histórico ou situação, mas é uma resposta dada por indivíduos definidos (apesar de se poder encontrar esta mesma resposta numa série de textos e, até certo ponto, a resposta possa se tornar tão geral 
que também se torna anônima). (...) Estas respostas não são coletivas de algum tipo de inconsciente coletivo. (...) E o fato de que uma resposta não seja uma representação nem um efeito de uma situação não significa que ela não responde a nada, que é um puro sonho ou anticriação. (Foucault, 2001b: 172) ${ }^{58}$

A noção de vida se constitui por meio de um conjunto de problemas, noções e enfoques que não devem ser tomados, em seu pensamento, de forma sistemática, pois nele não há um fio condutor linear, pautado por uma preocupação de progresso do conhecimento para o estabelecimento de teorias cada vez mais verdadeiras. A complexidade de sua concepção de vida só pode ser compreendida em sua multiplicidade e respeitando as inflexões de sua trajetória, na qual conceitos e métodos são retificados, reabilitados, mas, também, abandonados ou agregados - e isto não pode deixar de ser ressaltado.

É deste ponto de vista que deve ser entendida a mudança de perspectiva: da questão das condições de existência das formas modernas de objetivação do sujeito e da vida - pelos saberes (ciências, filosofia, literatura, artes) e pelos poderes (poder disciplinar e biopoder) - para uma outra questão, a das condições de possibilidade de formas de subjetivação ativas, formas de existência (bios), buscadas em experiências inteiramente afastadas dos procedimentos modernos do saber-poder da normalização, como as da Antiguidade greco-romana.

A vida se insere num quadro filosófico de distanciamento de nosso presente, cuja meta é diagnosticá-lo, criticá-lo e imaginá-lo diferente. Nele, o pensamento é fronteiriço, constituindo-se nos limites epistemológicos, políticos e éticos: 1) nos limites do saber, não só quando Foucault mostra, nas epistémés, aberturas que desembocam em novas configurações de saber, mas quando aponta possibilidades de transgressão das formas modernas de dominação por meio da filosofia e, sobretudo, da literatura; 2) nos limites das práticas do poder disciplinar e da biopolítica, quando formula as hipóteses da imanência da resistência e da instransitividade da liberdade na rede de relações de forças, compreendidas como estratégias abertas e móveis do poder, marcadas por ultrapassagens históricas e singulares; 3) nos limites da ética, quando este tema é pensado na linha de uma estética da existência, fundada numa atitude crítica e no trabalho de reinvenção do sujeito, de sua permanente autotransformação, para o governo de si e dos outros através da produção de verdades - sua hipótese da possibilidade de novas formas de subjetivação a partir de uma estilização de vida.

\footnotetext{
${ }^{58}$ Tradução minha de todas as citações desta obra.
} 
É neste quadro filosófico que se afirmam a exigência de um esforço permanente do pensamento para escapar de si mesmo e a tentativa de mostrar que as pessoas são muito mais livres do que pensam. Neste sentido, o papel da genealogia é importante: ela torna visíveis as falsas necessidades tanto de práticas quanto de temas considerados evidentes e verdadeiros e que foram fabricados, permitindo, assim, criticar e destruir sua pretensa evidência. Do ponto de vista político, este quadro mostra-se relevante, na medida em que possibilita responder à questão quem somos nós no presente e como nos tornamos quem somos, de modo a provocar novas formas de pensar sobre nós mesmos e sobre o mundo.

Ao dedicar-se a esta questão, considerando-a uma tarefa primordial da filosofia, Foucault alinha-se, em seu pensamento tardio, com Kant, como se pode ver em seu texto sobre o Iluminismo (Foucault, 1994d). A distinção foucaultiana de duas grandes tradições críticas da filosofia moderna - a da analítica da verdade, que estuda as condições sob as quais um conhecimento verdadeiro é possível, e a da ontologia de nós mesmos, na qual Focault se insere, cuja questão é o que é nossa atualidade e qual o campo atual de experiências possíveis - contribui indiscutivelmente com uma reflexão original que estabelece uma ligação inovadora entre preocupações epistemológicas, éticas e políticas.

Tradicionalmente a ontologia é um campo de análise delimitado pela investigação das estruturas metafísicas do ente. Fazer ontologia do presente significaria, portanto, reunir domínios incompatíveis: a história e a metafísica. Contudo, a breve apresentação feita por Foucault das concepções kantiana e baudelairiana de modernidade aponta claramente para um cruzamento da reflexão crítica sobre o uso da razão com a reflexão histórica sobre a finalidade interior do tempo (Foucault, 1994d). É justamente ao inseri-la neste contexto que sua reflexão sobre a atualidade torna-se ainda mais interessante. É a relação entre história, atualidade e crítica, que Foucault define como atitude de modernidade, que consiste na valorização do presente, indissociável da obstinação em imaginá-lo de um modo diferente do que é e em transformá-lo.

As análises foucaultianas ligam-se ao elemento da invenção. Mas, isto não deve configurá-las como o oposto da verdade, nem como arbitrário, nem como um idealismo histórico, conforme ele explica nos anos 80:

Pois, quando digo que estou estudando a 'problematização' da loucura, do crime ou da sexualidade, isto não é um modo de negar a realidade de tais fenômenos. Ao contrário, tentei mostrar que isto era 
precisamente algo realmente existente no mundo e que era o objetivo da regulação social num dado momento. A questão que levantei foi a seguinte: como e por que coisas de mundos muito diferentes foram reunidas, caracterizadas, analisadas e tratadas como, por exemplo, 'doença mental'? Quais são os elementos relevantes para uma dada problematização? (Foucault, 2001: 171)

A base desta formulação encontra-se no projeto de pesquisa das ciências do homem, que, conforme o próprio Foucault afirma, depois de As Palavras e as Coisas, é uma "genealogia nietzschiana". Isto porque visa à análise histórica que se opõe ao desdobramento meta-histórico das significações ideais e das teleologias indefinidas, que se opõe à unidade do discurso histórico e à busca da origem. Ela trabalha a partir da diversidade e da dispersão, do acaso dos começos e dos acidentes: em nenhum caso pretende recuar no tempo para restabelecer a continuidade da história, mas ela tenta, ao contrário, restituir os acontecimentos em sua singularidade.

A invenção fornece um quadro de inteligibilidade a respeito dos enunciados de verdade (científicos, éticos, políticos etc.) e daquilo que significa deles partir para pensar. Assim entendida, ela configura a hipótese de que o sujeito não é dado e tem sempre de ser inventado. Isto porque uma relação de poder se articula sobre dois elementos que lhe são indispensáveis: primeiro, a exigência de que aquele sobre cuja vida se exerce seja inteiramente reconhecido e mantido, até o fim, como o sujeito de ação; segundo, que se abra, diante da relação de poder, todo um campo de respostas, reações, efeitos, invenções possíveis.

Tal hipótese conduz à seguinte questão: onde encontramos regiões de disponibilidade para novas apreensões, nas quais a resistência se articula com a invenção, com a experimentação? De que modo é possível colocar a questão do como contornar formas políticas que incidem sobre nossas vidas? Como podemos nos dirigir com o objetivo de traçar alternativas às instituições, cuja crise se arrasta desde o século XIX, levando em consideração que, em crise, os critérios de verdade se multiplicam, concorrem entre si ou desaparecem, abrindo-se a novos modos de ver e viver, disponibilizando novos espaços e novas margens.

A pesquisa do conceito de vida na obra de Foucault evidencia a exigência de um recorte bastante complexo. Vida articula-se a outros conceitos, muito centrais, como o olhar, a morte, o homem, a sexualidade e o poder, inserindose nestes diferentes e consecutivos níveis ou dimensões de análise, dentre os quais serão aqui priorizados o da arqueologia dos saberes e o da genealogia dos 
poderes. A passagem de um nível a outro é marcada por descontinuidades temáticas e reformulações metodológicas sem solução de continuidade, inflexões determinantes. Uma vez que a genealogia das formas de subjetivação afasta-se do tema das ciências da vida proposto neste livro, dois pequenos ensaios a este respeito serão aqui apresentados apenas a título de adendo. ${ }^{59}$

A complexidade do recorte temático que a noção foucaultiana de vida impõe pode-se traduzir, até certo ponto, na afirmação de que seu percurso foi um movimento em zigue-zague, pois As Palavras e as Coisas, diz Foucault, é um livro que não estava na linha direta de seu problema. Em Histoire de la Folie à l'Âge Classique (1972), o problema central era o funcionamento do saber médico quanto à relação do louco e do não-louco na modernidade. O saber médico passou por uma evolução muito rápida, que ocorreu no final do século XVIII, fazendo aparecer não somente a psiquiatria e a psicopatologia, mas também a biologia e as ciências humanas.

Abra qualquer livro antigo de medicina de 1780 e qualquer livro antigo de 1820, passou-se de um mundo ao outro... É mesmo necessário ter lido muito pouco este gênero de obra, seja de gramática, medicina ou economia política, para imaginar que deliro quando falo de um corte no final do século XVIII! As Palauras e as Coisas só faz constatar este corte, traçar seu balanço, num certo número de discursos, essencialmente aqueles que giram em torno do homem, do trabalho, da vida e da linguagem... (...) As Palavras e as Coisas situava-se no nível da constatação do corte e da necessidade de ir buscar uma explicação. Vigiar e Punir é a genealogia, a análise das condições históricas que tornaram possível este corte. (Pol-Droit, 2006: 92)

É a partir destas considerações que se torna necessário ressaltar um primeiro ponto de interesse para esta pesquisa das ciências da vida. Trata-se do fato de que é na perspectiva de uma história do saber, envolvendo uma história das ciências, que a vida é interrogada no nível da arqueologia realizada por Foucault. A noção de vida é fundamental nos livros de arqueologia voltados para a pesquisa do surgimento, no início do século XIX, da clínica moderna, que Foucault chama de anatomoclínica, por meio de uma arqueologia do olhar, bem como para a pesquisa dos saberes do homem por meio de uma arqueologia das ciências humanas e para a dimensão antropológica da filosofia na modernidade. Nos livros de genealogia, que pode ser chamada de genealogia do poder,

\footnotetext{
59 Apêndice 1: Vida, Genealogia da Ética e Estética da Existência, e Apêndice 2: Govenamentalidade e Cuidado de Si.
} 
a vida aparece vinculada às formas de poder imanentes aos saberes investidos em campos como o corpo, a sexualidade, o indivíduo, a população.

Em O Nascimento da Clínica, a vida relaciona-se à constituição da medicina moderna - que, para Foucault, não é exatamente uma ciência - por meio da análise dos diferentes modos de apreensão do fenômeno patológico, do corpo do doente, da morte, da saúde e das formas de intervenção médica a partir do século XVIII. Em As Palavras e as Coisas, trata-se da história das ciências empíricas e sua relação com a filosofia moderna, com base no estudo da constituição da biologia e do discurso antropológico, no início do século XIX. Esta relação é detalhadamente analisada e já aparece na arqueologia da medicina, em que as ciências empíricas são ligadas à concepção filosófica de conhecimento de Descartes.

Foucault mostra, em O Nascimento da Clinica, que, na modernidade, o corpo doente apresenta-se como uma forma da vida, a patológica, que se constitui como um desvio interno da vida. Somente ao afastar-se da medicina clássica da representação, medicina das espécies ideais, é que a medicina moderna se constitui, tornando-se o primeiro tipo de conhecimento científico sobre o indivíduo doente. Os fenômenos patológicos, estudados na época clássica como entidades ideais a serem classificadas de acordo com o modelo botânico ou zoológico, aparecem como uma realidade corpórea com vida, que é considerada a vida como uma realidade corpórea, como uma modalidade de vida, e que deve ser estudada utilizando-se os modelos da anatomia e da biologia.

Ao reunir, no século XIX, anatomia e medicina e contornar a medicina clássica da representação, a medicina moderna torna-se o primeiro tipo de conhecimento empírico da doença no indivíduo concreto. Torna-se, também, um dos primeiros saberes a relacionar o homem com seu corpo e, ao mesmo tempo, com sua finitude originária - a doença e a morte, pois, aos olhos da modernidade, o conhecimento da vida do homem se manifesta, primeiramente, a partir do homem morto, da localização da morte no corpo do homem. Há uma anterioridade da morte em relação ao conhecimento da vida, do mesmo modo que o conhecimento do patológico é condição da vida em seu estado normal.

Bichat e sua concepção de vida como conjunto das funções que resistem à morte são considerados, na arqueologia, o marco da medicina moderna. Para Foucault, a medicina moderna - que ele caracteriza como anatomoclínica - surge com a nova concepção morte compreendida como uma série de processos ou mecanismos múltiplos no espaço e dispersos no tempo, que 
não se identificam com os mecanismos da vida nem com os da doença. Desse modo, esta nova acepção de morte aparece, na arqueologia, como condição de possibilidade do conhecimento da vida, dos fenômenos orgânicos e de suas perturbações. Portanto, é Bichat que formula e introduz a concepção moderna de morte na medicina. Em As Palavras e as Coisas, a noção de vida constitui uma das condições de possibilidade do aparecimento da biologia no início do século XIX. A aparente ou quase continuidade entre as idéias e os temas da história natural e da biologia é considerada um efeito de superfície do nível arqueológico. É neste nível que Foucault situa as análises de suas pesquisas desenvolvidas nos anos 60.

Aí, ele traça uma descontinuidade entre o estudo dos seres vivos e o da vida, que corresponde a uma mutação profunda e maciça no sistema de conhecimento envolvendo o espaço geral do saber. Ao dirigir-se ao espaço geral do saber, a arqueologia estabelece relações entre diferentes domínios de conhecimento numa mesma época.

Se a história natural de Tournefort, de Lineu e de Buffon tem relação com alguma coisa que não ela mesma, não é com a biologia, a anatomia comparada de Cuvier ou o evolucionismo de Darwin, mas com a gramática geral de Bauzée, com a análise da moeda e da riqueza tal como a encontramos em Law, em Véron de Fortbonnais ou em Turgot. (Foucault, 2002a: XIX-XX)

Este é o ponto de partida de Foucault para afirmar que há, na época clássica, uma coerência interna entre a teoria da representação e a teoria da linguagem, a teoria das ordens naturais e a da riqueza e do valor. Tal coerência é que permite delimitar a configuração do saber da época clássica, situando todos os saberes - linguagem, ciências e filosofia - num só nível de conhecimento, o da representação. É esta configuração que muda, inteiramente, no início do século XIX, quando a representação deixa de ser considerada como o espaço privilegiado do saber, marcando uma descontinuidade entre a época clássica e a moderna. A representação perde sua clareza, torna-se opaca, e a linguagem não aparece mais como o meio mais transparente e único suporte para o conhecimento.

A teoria da representação deixa de ser o fundamento geral do pensamento, e a linguagem deixa de ser o campo indispensável para que o conhecimento possa relacionar a representação, as coisas e os seres vivos. O princípio de inteligibilidade dos seres é buscado não mais na ordem das representações, mas 
nos próprios seres, que passam a ser considerados como tendo uma existência independente, concreta e empírica. Uma historicidade profunda penetra no interior das coisas, isolando-as, definindo-as em sua própria coerência e instaurando o nível empírico do saber.

Ao final do século XVIII, o saber constituído pelo espaço unitário da representação reparte-se em dois níveis distintos: o nível empírico, dos objetos, que não são apenas representações mas têm uma existência própria, em que se situam as ciências empíricas modernas - a biologia, a economia política e a filologia ou a lingüística -, e o nível transcendental, do sujeito, instaurado com a questão kantiana das condições de possibilidade de toda representação.

Por um lado, a retirada dos seres vivos, das palavras e das riquezas do campo da representação possibilitou o aparecimento das sínteses objetivas da vida, do trabalho e da linguagem; por outro lado, a crítica do fundamento da teoria geral da representação permitiu contornar a representação, abrindo espaço para uma filosofia transcendental, centrada num sujeito que é condição de possibilidade de uma síntese possível entre as representações. A retirada da representação e o desnivelamento do solo epistemológico ${ }^{60}$ marcam o limite do pensamento clássico e o limiar da modernidade.

Em As Palavras e as Coisas, a noção de vida como objeto empírico é condição de possibilidade da constituição das ciências da vida. Seu surgimento é coetâneo da diferenciação dos dois níveis de pensamento, o empírico e o transcendental; é coetâneo, também, do aparecimento das outras ciências empíricas, a economia política e a lingüística ou a filologia, das ciências do homem e da confusão que fazem, juntamente com a filosofia moderna, entre estes dois níveis, confusão denunciada e rejeitada por Foucault em sua arqueologia da modernidade.

Apesar da distinção estabelecida por Kant do nível transcendental, tornase visível, na modernidade, que não apenas o conteúdo, mas também a forma do conhecimento empírico podem estar sujeitos às determinações empíricas. Os conteúdos das ciências empíricas - a vida, o trabalho e a linguagem - são elevados a objetos filosóficos, seja com a escatologia de Marx e do positivismo iniciado com Comte, seja com a dialética iniciada com Hegel. Se, em Kant, é clara a separação do empírico e do transcendental, na medida em que o sujeito, não sendo empírico, nunca se dá à experiência, a filosofia pós-kantiana confunde os dois níveis em sua análise do modo de ser do homem, questão central da filosofia

\footnotetext{
${ }^{60}$ Solo epistemológico, campo epistemológico, disposição epistemológica, episteme são expressões sinônimas.
} 
moderna e das ciências do homem. Este é, para Foucault, o grande problema do pensamento moderno que ainda não teria sido contornado.

A arqueologia mostra que, ao repetir a identidade e a diferença entre o empírico e o transcendental, o pensamento moderno - que Foucault caracteriza como discurso antropológico - é uma analítica da finitude do homem; finitude imposta do exterior pela determinação da vida, do trabalho e da linguagem, de sua historicidade; imposta, ainda, do interior, pois atinge a própria consciência do homem, limitando a forma do conhecimento. $\mathrm{O}$ problema é que esta repetição dos conteúdos empíricos no nível transcendental confere à filosofia moderna o caráter de uma analítica, de um pensamento do Mesmo, marcado por uma ambigüidade, pois, nesta reduplicação, aquilo que é dado na experiência e aquilo que a torna possível se correspondem numa oscilação infinita. O único meio, apontado por Foucault, de superação desta ambigüidade seria a dissolução do discurso antropológico.

Para tratar deste tema, é preciso, primeiramente, explicitar a relação entre a questão da história do conceito de vida e da constituição da biologia e a noção de representação na obra de Foucault, sua historicidade, seus diversos sentidos como categoria, forma ou objeto de saber, conforme tratados na arqueologia. A emergência da noção de vida e o aparecimento correlato da biologia, no início do século XIX, são analisados em O Nascimento da Clínica e em As Palauras e as Coisas, através de um recuo histórico até a época clássica, com a finalidade de especificar o saber da modernidade, diferenciando-o da forma do saber que lhe antecede.

Enquanto a noção de vida se institui como um objeto específico de saberes determinados da modernidade - a biologia e a anatomoclínica -, a noção de representação constitui o campo geral do pensamento clássico, sua própria configuração. A representação é analisada por Foucault de uma maneira bastante original. Ele rejeita os estudos até então desenvolvidos na linha da teoria do conhecimento ou da metafísica, bem como na linha da história das idéias ou das ciências, evidenciando o esforço da arqueologia em escapar de uma filosofia do sujeito ou da consciência.

A arqueologia não apresenta nenhuma preocupação com a definição de conhecimento, sujeito ou fenômeno, nem de unidade ou totalidade. Nunca problematiza a idéia no sentido de uma teoria lógica ou metafísica das idéias, nem discute a origem (no sentido platônico, de Leibniz ou do cartesianismo) deste conceito, pois o que está em jogo na arqueologia é um conjunto de análises sobre a constituição dos saberes sobre o homem na modernidade, 
em consonância com os quais se formam diversos saberes específicos que interessam a Foucault.

A questão da representação apresenta-se, então, como uma valiosa chave de interpretação das condições de possibilidade do pensamento na modernidade, na medida em que Foucault o compreende como uma crítica da própria condição do "Representar", ${ }^{61}$ explicando as singularidades de cada episteme - a da Renascença, a da época clássica e a da época moderna, em As Palavras e as Coisas. A noção de representação, na época clássica, constitui um dos eixos centrais das análises foucaultianas que dão corpo à história do pensamento por ele realizada.

Tal questão parece-me de fundamental importância para as análises histórico-filosóficas das ciências da vida. Isto porque, para Foucault, por um lado, a representação é uma categoria que configura o espaço geral do saber na época clássica; por outro, as sínteses objetivas das ciências empíricas e a analítica da finitude escapam do primado da representação na modernidade, mas não a abandonam completamente, porque, embora não a tomem mais como fundamento do saber, a tomam como seu objeto.

É pela análise de descontinuidades que ele compreende como cada positividade se modificou; é através da "alteração dos seres empíricos que povoam as positividades" e do deslocamento das positividades umas em relação às outras - por exemplo, a relação nova entre a biologia, as ciências da linguagem e a economia - que ele mostra que, no século XIX, o espaço geral do saber não é mais o das identidades e diferenças, o das ordens não quantitativas, o da caracterização universal da taxinomia geral e o da mathesis universalis.

Foucault analisa o pensamento cartesiano, particularmente em sua obra Regulae, identificando-o com uma nova concepção de saber, o clássico, quando o conhecimento deixa de ser uma busca de semelhanças para se tornar uma relação de ordenação entre idéias. Foucault aponta, em Descartes e a partir dele, não só o fundamento da matemática e da física, mas, sobretudo - e é isto o mais relevante para o tema das ciências da vida - o da história natural, da análise das riquezas e da gramática. No nível arqueológico, não há, na época clássica, diferença entre os saberes científicos e a filosofia. Eles têm a mesma configuração: todos são conhecimentos analíticos, análises que se passam no nível da representação, cujos objetos são as representações a serem ordenadas, nomeadas, classificadas. A diferença é apenas de amplitude.

${ }^{61}$ O capítulo "Representar" de As Palavras e as Coisas é central para a arqueologia das ciências humanas. 
A história natural não pode - e esta é uma das teses de As Palavras e as Coisas - se constituir, progressivamente, como biologia. Até o final do século XVIII, com efeito, afirma Foucault, a vida não existe; existiam apenas os seres vivos que formam uma, ou antes, diversas classes hierarquizadas na série de todas as coisas do mundo. Só podemos falar de vida na época clássica no sentido taxonômico. O naturalista Jussieu tenta estabelecer uma classificação rigorosa de acordo com as regras de subordinação dos caracteres numa unidade de plano, justapondo varáveis no mesmo espaço. Aí, as variáveis são independentes e percorridas pela linguagem e pelo olhar. Classificar e falar se originam no mesmo espaço, aberto pela representação.

A descrição dos seres naturais deve ser analítica: decomposição do todo através da observação da estrutura - conjunto de elementos - detalhando suas partes, comparando, classificando, nomeando-os individualmente, confrontando-os para estabelecer vizinhanças, parentescos e separações, a partir do conhecimento das identidades e diferenças, agrupadas segundo a estrutura visível - o caráter - dos seres vivos. A descrição clássica é acompanhada pela observação, pela clareza do olhar de superfície; ela relaciona o visto com o dito. Foucault faz esta articulação na surpreendente expressão "olhar loquaz" do médico. As palavras representam as coisas, buscando sistematizar-se numa linguagem perfeita, do ponto de vista de sua lógica interna, que forma o quadro do mundo.

A história natural obedecerá a esta mesma exigência de uma linguagem bem elaborada, em que os signos de convenção serão privilegiados devido à maior exatidão que oferecem, cuja função é denominar o visível através de um sistema de signos, a serem transcritos em palavras e transportados para o nível das representações, traduzindo o objeto da visão.

Em o Nascimento da Clínica, a história natural articula-se com a medicina classificatória das espécies patológicas, para a qual a doença é uma essência abstrata, uma idéia, uma representação. O quadro nosológico implica uma configuração das doenças diferente do seu desenrolar causal no corpo humano. Na época clássica, a localização da doença no organismo é secundária com relação ao sistema de ordenação em quadros, a partir do qual a doença recebe uma organização hierarquizada em famílias, gêneros e espécies. $\mathrm{O}$ olhar classificatório percebe a doença num espaço sem profundidade e de coincidência, sem qualquer relação com seu desenvolvimento, não importando o desdobramento temporal e apresentando-se, portanto, apenas por meio de um plano e de um instante. 
O duplo poder atribuído à representação - fundar o conhecimento a partir do significado situado no interior da representação do signo e, ao mesmo tempo, representar a idéia que ela representa é desqualificado ao final do século XVIII. De acordo com Foucault, enquanto Hume interrogava o problema da causalidade na perspectiva de uma investigação geral das semelhanças, das identidades e diferenças - sendo, portanto, um pensador clássico -, Kant, isolando a causalidade, levanta a crítica à própria noção de representação e conduz sua investigação para a busca das condições de possibilidade de todo o conhecimento, da própria representação. O objeto empírico torna-se concreto, sintético, não mais ideal; torna-se independente do conhecimento.

No campo das ciências empíricas, Cuvier é um marco fundamental da modernidade. Ele deixa de privilegiar o saber que busca a dimensão de superfície dos seres, sua estrutura visível, que caracteriza o saber clássico. Cuvier estabelece uma relação entre o saber e a dimensão de profundidade das superfícies tridimensionais e invisíveis que buscam conhecer a organização dos seres, seu espaço volumoso, seus órgãos, enfim, a espessura da vida. A noção de vida só aparece quando a representação deixa de fundar o pensamento e os corpos apresentam-se em seu volume.

É importante lembrar que Foucault, Jacob e Canguilhem concordam ao afirmarem esta descontinuidade, em contraposição à história que atribui à passagem da história natural para a biologia não o caráter de ruptura, mas o de um progresso cumulativo e linear do conhecimento científico, considerando a primeira um passo imperfeito para o conhecimento finalmente positivo da biologia. Isto não quer dizer, sem dúvida, que os epistemólogos e o arqueólogo realizem o mesmo tipo de análise.

A descontinuidade entre a história natural e a biologia se estabelece a partir de Cuvier, e não de Lamarck, apesar de o nome biologia já ter aparecido com Lamarck, Treviranus e Oken. Tal perspectiva foi explicitada, pela primeira vez, por Henri Daudin, professor da Universidade de Bordeaux, que, em sua tese, de 1926, sobre os métodos de classificação desenvolvidos por Lineu, Lamarck e Cuvier, mostra a não existência de conceitos evolucionistas em Lamarck (apud Canguillem, 1967). Daudin é apontado, por Piveteau nas Jornadas Cuvier (Foucault, 1994a), para reforçar a idéia de transpor o modo de classificar de Cuvier aos dias de hoje. Daudin é citado por Canguilhem (1967), para mostrar que sua tese inspira as análises de Foucault que traçam redes conceituais na descrição da formação da episteme moderna. Tal perspectiva a respeito de 
Cuvier, contudo, é rejeitada por François Dagognet (1970) nas Jornadas Cuvier, realizadas no Institut d'Histoire des Sciences. Dagognet rejeita a afirmação de que Cuvier é moderno, pois o considera um naturalista clássico.

No entanto, a hipótese de Foucault é que, somente com Cuvier, o conhecimento não se fará mais no nível exclusivo da representação. À medida que o conhecimento das coisas faz com que elas se voltem sobre si mesmas, sobre sua própria historicidade, e seu princípio de inteligibilidade interno é buscado, surge a noção de homem, pela primeira vez, no sentido das chamadas ciências do homem. A partir da análise das empiricidades e da filosofia, cria-se um espaço no saber entre o empírico e o transcendental. Foucault estuda este espaço, que não é mais nem o domínio do empírico nem do transcendental; é o espaço da representação como objeto e do homem como representação. Afirma que, à medida que as coisas enrolam-se sobre si mesmas, solicitando, apenas a seu devir, o princípio de sua inteligibilidade e abandonando o espaço da representação, o homem entra, pela primeira vez, no campo do saber ocidental, inaugurando as ciências do homem.

Foucault chega à relação do campo biológico com o político a partir das seguintes hipóteses, com as quais trabalha na genealogia do poder: 1) existe uma relação entre saber e poder; 2) as ciências do homem podem ser consideradas um prolongamento das ciências da vida, porque se fundam biologicamente; 3) os conceitos biológicos não são pensados apenas por meio da estrutura interna do ser vivo (organizado), mas se articulam com dispositivos de poder, diretamente ligados a processos fisiológicos; 4) o nível biológico e o histórico se ligam, de acordo com uma complexidade crescente, à medida que são desenvolvidas tecnologias modernas de poder, as quais tomam por alvo a vida.

Em Vigiar e Punir e em História da Sexualidade 1, são traçadas continuidades e descontinuidades entre as formações discursivas, e entre estas e as práticas, formas de exercício de poder, da época clássica e aquelas desenvolvidas na época moderna. Contudo, tais continuidades e descontinuidades não correspondem às mesmas preocupações nem aos mesmos objetos que conduziram as pesquisas arqueológicas. Há, sem dúvida, uma descontinuidade entre o conceito arqueológico de vida e o genealógico, pois a arqueologia do saber busca o nível profundo das condições de possibilidade da existência dos saberes - das ciências, da filosofia, da literatura, da pintura. Na série de estudos arqueológicos, encontramos análises meticulosas da constituição dos saberes científicos, realizadas através de um trabalho notadamente paciente de história das ciências. 
Ainda que sempre remetidas ao nível arqueológico e à dimensão dos efeitos de superfície deste nível mais profundo, durante a década de 1960, as ciências se impõem como um ponto de passagem obrigatório para Foucault. ${ }^{62}$ A partir de Vigiar e Punir, a questão de Foucault sofre desvios e suas análises passam a se dirigir, por meio de uma genealogia, às tecnologias de poder e suas transformações, do século XVII até nossos dias. ${ }^{63}$ Seu objetivo, então, é a constituição dos saberes no nível que os remete à dimensão de sua imanência com as relações de forças. De fato, neste projeto, o interesse pelas ciências da vida as situa num outro nível bastante diferente.

Em entrevista a Gérard Raulet, Foucault refere-se a seu movimento, ainda que retrospectivamente, como um deslocamento e um abandono do termo arqueologia:

Se empreguei esse termo arqueologia, que já não uso atualmente, era para dizer que o tipo de análise que eu fazia estava deslocado, não no tempo, mas pelo nível em que se situa. Meu problema não era estudar a história das idéias em sua evolução, mas sobretudo ver debaixo das idéias como puderam surgir tais ou tais objetos possíveis de conhecimento. Porque, por exemplo, a loucura tornou-se, em um dado momento, um objeto de conhecimento correspondendo a um certo tipo de conhecimento. Usando a palavra 'arqueologia' em vez de 'história', eu quis marcar essa decalagem entre as idéias sobre a loucura e a constituição da loucura como objeto. (Foucault, 2000: 319-320)

A genealogia das formas de poder exercidas na modernidade por mecanismos específicos, que conduz Foucault a caracterizá-lo como poder disciplinar, em Vigiar e Punir, complementa-se em História da Sexualidade 1, com a investigação de tecnologias de governo que lhes são coextensivas. São tecnologias que constituem dispositivos de regulação e de segurança da população e que estão na origem de ciências, como a estatística, a demografia, a economia, a geografia e a epidemiologia.

${ }^{62}$ Justamente nesse período em que a literatura tem uma função positiva de contestação do humanismo das ciências do homem e das filosofias modernas, é que Foucault de fato pesquisa as ciências, a ponto de afirmar, mais tarde, em 1971, quando suas investigações já haviam se dirigido à questão do poder, que, naquela época, "pensava, no fundo, estar fazendo história das ciências" (Foucault, 1994a: 157).

${ }^{63}$ Em entrevista a Droit, Foucault assinala como foi longo o tempo necessário para que ele ajustasse seu enfoque: "Com efeito (...), eu levei sete anos para perceber que a solução não devia ser buscada onde eu a buscava, em qualquer coisa do gênero ideologia, progresso da racionalidade ou modo de produção. Era, finalmente, nas tecnologias de poder e em suas transformações, do século XVII até agora, que era necessário ver a base a partir da qual a mudança seria possível” (Pol-Droit, 2006: 92). 
Tais mecanismos são analisados primeiramente por meio de uma analítica do poder centrada na noção de tecnologias do poder; em seguida, a partir da questão da relação do direito de morte e poder sobre a vida dos indivíduos e das populações (Foucault, 2001a), por meio de uma análise fundada na noção de governo, de poder como condução de condutas e ordenação de probabilidades, de uma 'governamentalidade' política, conforme começa a se desenhar na genealogia no final dos anos 70. Governo, então, é tomado em sua significação bastante ampla, do século XVI, quando não se referia apenas às estruturas políticas e à gestão dos Estados, mas designava a maneira de dirigir a conduta dos indivíduos ou dos grupos - das crianças, das almas, das comunidades, das famílias, dos doentes.

A noção de governo recobre modos de ação refletidos e calculados, destinados a agir sobre as possibilidades de ação dos outros indivíduos, que não devem ser investigados em termos de violência ou luta, nem de contrato ou aliança voluntária - que são apenas seus instrumentos - mas em termos de ação. Para Foucault, as ações do governo dos homens, uns pelos outros, no sentido mais extenso da palavra, incluem necessariamente o elemento da liberdade: "Não há, portanto, um confronto entre poder e liberdade, numa relação de exclusão; mas um jogo muito mais complexo" (Foucault, 1995: 244) ${ }^{64}$

Realmente são inúmeras as dificuldades indicativas do problema da transposição metodológica e temática da história dos saberes para a pesquisa genealógica. este problema é, em si mesmo, profícuo; ele se deve, de fato, à originalidade e à abertura do pensamento foucaultiano. É a sua configuração que estabelece a exigência de um trabalho filosófico complexo ao se tentar isolar o conceito de vida na história foucaultiana. Em contrapartida, a vida constitui um excelente fio condutor para o leitor da obra de Foucault.

Estas dificuldades se refletem em diferentes tipos de análise da obra de Foucault realizados em consonância com as formas de interpretar a passagem da arqueologia para a genealogia. Podemos citar três exemplos de posições

\footnotetext{
${ }^{64}$ Segundo Ortega, desde 1976, constata-se um deslocamento teórico do conceito de poder para o de governo, conduzindo ao tema do governo de si. Ele ressalta que Foucault admite ter estado preso, até o começo dos anos 70, a uma noção negativa de poder. Essa noção foi substituída pela concepção de um poder produtivo de verdade e de objetos. Em História da Sexualidade 1, segundo Ortega, Foucault defende uma concepção monista de poder, inspirada em Nietzsche, como multiplicidade de relações de força. "Com a passagem para a análise das tecnologias de governo, Foucault amplia, graças a Habermas, sua concepção de poder para um tipo determinado de relações de indivíduos, ou seja, uma forma de relação social junto a outras. Assim, o conceito de poder é substituído pelo conceito de 'governo', considerado por Foucault mais operacional" (Ortega, 199: 35).
} 
importantes a este respeito. Primeiro, as críticas de Béatrice Han (1998) ao discutir a passagem da arqueologia à genealogia, buscando, equivocadamente, nos conceitos fundamentais do projeto de Foucault, o caráter de unidade e de sistema, a partir do qual aponta falhas em seu pensamento. Segundo, a insistência de Machado (2006: 177) do caráter hipotético, específico e transformável das análises arqueológicas e genealógicas de Foucault, "para que não se tomem essas investigações como uma palavra final, um caminho definitivo, um método universal” - com a qual concordo. E ainda, sua observação:

Se prefiro caracterizar os estudos dessa época como uma genealogia do poder, e não do saber, é para assinalar que, embora o objetivo final das análises tenha continuado a ser a constituição dos saberes, Foucault deteve-se fundamentalmente na investigação dos poderes que lhe estão intrinsecamente ligados. (Machado, 2006: 177).

Terceiro, o comentário de Edgardo Castro (2009: 189):

um modo correto de enfocar o trabalho de Foucault, na condição, no entanto, de que não se acentuem demasiadamente tais deslocamentos. Por deslocamentos não entendemos abandonos, mas sim extensões, ampliações do campo de análise. Com efeito, a genealogia não abandonará o estudo das formas de saber (...) mas cada um desses âmbitos será reenquadrado em um contexto mais amplo.

Dentre as inúmeras dificuldades referidas, convém, para efeito deste estudo, salientar a seguinte: enquanto, em o Nascimento da Clínica, as rupturas mencionadas obedecem, no tempo, às mesmas articulações de As Palavras e as Coisas, formando uma série, iniciada com a História da Loucura; na genealogia, estes mesmos saberes são apresentados de uma forma muito diferente daquilo que podemos considerar história das ciências, pois são questionados do ponto de vista da estratégia, do dispositivo. A pesquisa é dirigida pelas noções de acontecimento e de campos de força aplicados às formações discursivas. Aí, a questão que se coloca é atravessada por uma analítica do poder em sua forma de exercício específica a cada época. Neste caso, as cronologias dos dispositivos, continuidades e descontinuidades não obedecem exatamente - nem necessitam fazê-lo - aos limites demarcados pela arqueologia.

Contudo, é possível relacionar a biologia estudada pela arqueologia com o tratamento da questão da vida do ponto de vista político. Isto porque, ao mesmo tempo que podemos ver, em Foucault, uma espécie de afastamento da arqueologia, encontramos a possibilidade de sua ligação com a genealogia, 
justamente, através do conceito de vida. O estudo da constituição das ciências da vida em seu nível arqueológico é reabilitado, não sem transformação, é claro, pelo projeto genealógico, segundo o qual não há constituição de um campo de saber sem novas relações de poder e vice-versa.

Em História da Sexualidade 1, Foucault mostra que, a partir do século XVIII - quando aparece o domínio da biologia como ciência da vida - cada vez mais, os mecanismos do poder se dirigem ao corpo, à vida, o que faz proliferar, o que reforça a espécie, a saúde e a vitalidade do corpo social, em oposição à morte. ${ }^{65}$ Os novos procedimentos de poder, elaborados durante a época clássica e postos em ação no século XIX, atuam sobre a vida dos indivíduos e das populações através da norma, do saber, da disciplina e das regulamentações. O poder disciplinar atinge o corpo vivo do indivíduo, com táticas específicas, ordenando e, sobretudo, homogeneizando as diferenças humanas.

O poder, na época clássica, marca seu direito sobre a vida pela morte que pode exigir, ou melhor, direito de causar a morte ou de deixar viver.

Por muito tempo, um dos privilégios característicos do poder soberano fora o direito de vida e morte. Sem dúvida, ele deriva formalmente da velha patria potestas que concedia ao pai de família romano o direito de "dispor" da vida de seus filhos e de seus escravos; podia retirar-lhes a vida, já que a tinha "dado". O direito de vida e morte como é formulado nos teóricos clássicos é uma fórmula bem atenuada desse poder. (Foucault, 2001a: 127)

Ele se constituía, sobretudo, como direito de apreensão das coisas, de confisco do tempo, dos corpos e da vida; culminava com o privilégio de se apoderar da vida para suprimi-la. Entretanto, este confisco tende a ser uma entre outras funções do poder, cuja função principal passa a ser produzir forças, fazê-las crescer e ordená-las mais do que barrá-las ou destruí-las. O direito de morte tenderá, então, a se apoiar nas exigências de um poder que gere a vida: "Essa morte, que se fundamentava no direito do soberano de defender ou pedir que o defendessem, vai aparecer como o simples reverso do direito

\footnotetext{
${ }^{65}$ Branco (2009: 288) chama a atenção para a idéia de um biopoder que "representa um acréscimo ao agenciamento entre o judiciário e o saber médico que se consolidou nos fins do século XVII. O que foi gerado de fins do século XIX até hoje, segundo Foucault, quando se ampliou o raio de ação política do biopoder, é dramático. Pois o exercício do biopoder passa a revelar um modo de funcionamento paradoxal: voltado para o controle e gestão de sua população e de tudo o que pode ameaçá-la, com epidemias, doenças e até mesmo inimigos nacionais, países rivais, a partir do século XX, os regimes passaram a realizar 'holocaustos sobre sua própria população'.”
} 
do corpo social de garantir sua própria vida, mantê-la ou desenvolvê-la" (Foucault, 2001a: 128).

O poder começa a se exercer, positivamente, sobre a vida, empreendendo sua gestão, sua majoração, o exercício sobre ela, através de controles precisos e regulações de conjunto. As guerras já não se travam em nome do soberano, mas em nome de todos - das populações inteiras que são levadas à destruição mútua em nome da necessidade de viver. São mortos legitimamente aqueles que representam uma espécie de perigo biológico para os outros. No curso Em Defesa da Sociedade, Foucault (2002b: 305) afirma que "a morte do outro, a morte da raça ruim, da raça inferior (ou do degenerado ou do anormal), é o que vai deixar a vida em geral mais sadia; mais sadia e mais pura”.

Foucault ressalta um dos grandes perigos desta forma de poder, que ele considera uma das maiores patologias da modernidade, o aparecimento do racismo:

É assim que vocês vêem aparecer algo que vai ser justamente o racismo. Retomando, reciclando a forma, o alvo e a própria função do discurso sobre a luta de raças, mas deturpando-o, esse racismo se caracterizará pelo fato de que o tema da guerra histórica - com suas batalhas, suas invasões, suas pilhagens, suas vitórias e suas derrotas - será substituído pelo tema biológico, pós-evolucionista, da luta pela vida. Não mais batalha no sentido guerreiro, mas luta no sentido biológico: diferenciação das espécies, seleção do mais forte, manutenção das raças mais bem adaptadas, etc. (...). Quando o tema da pureza da raça toma o lugar do da luta das raças, eu acho que nasce o racismo. (Foucault, 2002b: 95)

Para Foucault, este poder sobre a vida desenvolveu-se, concretamente, em duas formas principais e complementares. Primeiramente, o adestramento do corpo considerado como máquina, conforme mostra em Vigiar e Punir; ampliação de suas aptidões, extorsão de suas forças, crescimento paralelo de sua utilidade e docilidade, sua integração de controles eficazes e econômicos. É nisto que consiste a anatomopolítica do corpo humano que se caracteriza pela ação disciplinar sobre o indivíduo, seu corpo.

A segunda forma de desenvolvimento foi, a partir do século XVIII, quando o poder sobre a vida centrou-se no corpo-espécie, traspassado pela mecânica do ser vivo, suporte dos processos biológicos: a proliferação, os nascimentos e a mortalidade, o nível de saúde, a duração da vida, a longevidade, com todas as condições que podem fazê-los variar. Estes processos são assumidos mediante uma série de intervenções e controles reguladores, que Foucault chama de 
biopolítica da população. O seu papel mais importante é garantir, sustentar, reforçar, multiplicar a vida e colocá-la em ordem. ${ }^{66}$

A noção de população como problema econômico e político, como representando riqueza, mão-de-obra ou capacidade de trabalho, em equilíbrio, só aparece no século XVIII, quando os governos percebem que não têm de lidar, apenas, com sujeitos ou povos, mas com um conjunto de variáveis específicas natalidade, fecundidade, saúde ou doença, alimentação, habitação etc. Estas variáveis situam-se no ponto de interseção entre os movimentos próprios à vida e os efeitos particulares das instituições.

As disciplinas do corpo e as regulações da população constituem dois pólos em torno dos quais se organizou o poder sobre a vida, que é considerado por Foucault como uma grande tecnologia de poder de duas faces, a anatômica e a biológica:

A instalação - durante a época clássica, desta grande tecnologia de duas faces - anatômica e biológica, individualizante e especificante, voltada para os desempenhos do corpo e encarando os processos da vida - caracteriza um poder cuja função mais elevada já não é mais matar, mas investir sobre a vida... (Foucault, 2001a: 131)

Trata-se da administração dos corpos, gestão calculista da vida, através de técnicas e diversas disciplinas (das escolas, casernas, ateliês), práticas políticas e observações econômicas dos problemas de natalidade, longevidade, saúde pública, habitação e migração.

As duas direções ainda aparecem de forma bem separadas no século XVIII. A partir do século XIX, o poder transforma-se em agenciamentos concretos - o dispositivo da sexualidade, por exemplo, será um deles - que constituirão a grande tecnologia do poder no século XX, capaz de majorar as forças, a vida em geral, através da inserção controlada dos corpos no aparelho de produção e por meio de um ajustamento dos fenômenos de população aos processos econômicos.

\footnotetext{
${ }^{66}$ Foucault salienta a concepção moderna de população como essência natural a ser governada pelo Estado: "Existe, pois, uma naturalidade intrínseca à população. E, por outro lado, outra característica específica da população é que se produz, entre cada um dos indivíduos e todos os outros, toda uma série de interações, de efeitos circulares, de efeitos de difusão que fazem que haja, entre um indivíduo e todos os outros, um vínculo que não é o vínculo constituído e desejado pelo Estado, mas que é espontâneo. É essa lei da mecânica dos interesses que vai caracterizar a população. Naturalidade da população, lei de composição dos interesses no interior da população, eis que a população, como vocês estão vendo, aparece como uma realidade muito mais densa, espessa, natural, do que aquela série de súditos submetidos ao soberano (...)" (Foucault, 2008a: 473).
} 
Os rudimentos da anátomo e biopolítica, inventados no século XVIII como técnicas de poder presentes em todos os níveis do corpo social e utilizadas por instituições bem diversas (a família, o Exército, a escola, a polícia, a medicina individual ou a administração das coletividades) agiram no nível dos processos econômicos, do seu desenrolar, das forças que estão em ação em tais processos (...) a entrada dos fenômenos próprios à vida da espécie humana na ordem do saber e do poder - no campo das técnicas políticas. (Foucault, 2001a: 132)

O homem aprende, explica Foucault, pouco a pouco, o que é ser uma espécie viva, num mundo vivo, ter um corpo, condições de existência, probabilidade de vida, de saúde individual e coletiva, forças que podem se modificar e um espaço em que se pode reparti-las de modo ótimo. Assim, o biológico reflete-se no político:

Pela primeira vez na história, sem dúvida, o biológico reflete-se no político; o fato de viver não é mais esse sustentáculo inacessível que só emerge de tempos em tempos, no acaso da morte e de sua fatalidade: cai, em parte, no campo de controle do saber e de intervenção do poder. (Foucault, 2001a: 134)

Contudo, Foucault nos adverte para o perigo desta forma de dominação. Para ele, não há nada mais tirânico e fatal do que colocar a vida sob o signo de uma ciência ou de uma ideologia, ou melhor, de uma exigência de verdade, onde o papel do saber não é apenas produção de verdade, mas o exercício de poder. Para ele, nas sociedades capitalistas, o poder é negativo e repressivo, mas tem uma eficácia produtiva, uma positividade que necessita ser conhecida: a da gestão da vida dos indivíduos e das sociedades, para a qual produz uma série de saberes específicos, capazes de auxiliar, como dissemos, na função de tornar os indivíduos dóceis, do ponto de vista político, e produtivos, do ponto de vista econômico.

Surgem, neste ponto, a questão do conceito de vida e a busca das formas de problematização que conduziram à interrogação das condições de possibilidade de seu aparecimento, de sua existência.

Em suma, são duas as formas da investigação foucaultiana da vida de maior interesse para os ensaios aqui reunidos, visando ao estudo das formas históricas de problematização das ciências da vida. Primeira: a que se estabelece quando se institui o nível da arqueologia do saber em que a filosofia e as ciências da vida são articuladas; segunda: a forma de problematização genealógica da vida. 
Dois eixos de hipóteses são tomados como ponto de partida. Um diz respeito ao problema arqueológico da ordenação, da representação e da constituição do objeto em Descartes e, no limiar da modernidade, em Kant; o outro refere-se à análise genealógica da questão da vida do indivíduo e das populações.

As hipóteses do eixo referente à arqueologia são: primeira, o tema da vida e sua constituição como objeto é, do ponto de vista da filosofia das ciências, uma das mais importantes chaves de interpretação para a determinação histórica das condições de possibilidade da formação do saber científico e filosófico sobre a vida da modernidade, que, apesar de dirigir-se a um nível mais 'profundo' ou 'anterior' ao nível das ciências - o do olhar, de sua articulação com a linguagem, e do saber -, o interesse de Foucault em fazer história das ciências não é pequeno, nem sua avaliação das ciências tão negativa quanto parece -, pois, na modernidade, ao contrário da filosofia, as ciências lhe parecem escolhas originais autônomas.

De acordo com a definição de Foucault, estas escolhas são originais não somente na medida em que são especulativas, pertencentes ao domínio das idéias puras, mas também porque delimitam todo um conjunto constituído pelo saber humano, as atividades humanas, a percepção, a sensibilidade. Tradicionalmente, elas eram elaboradas pela atividade de uma filosofia autônoma, mas, hoje, em sua opinião, acontecem em outras atividades, sejam científicas, políticas ou literárias. A avaliação de Foucault, contudo, é muito negativa quanto às práticas institucionais vinculadas às ciências da vida.

A segunda hipótese do eixo referente à arqueologia é que seu interesse em analisar as ciências da vida, que se dissipa ao final dos anos 60 , não se restringe a questões de filosofia e história das ciências, mas, por sua amplitude, aprofunda a questão crítica e o diagnóstico do presente, deixando claro o papel de Kant para a configuração do saber na modernidade.

Quanto ao segundo eixo, que diz respeito à análise genealógica da questão da vida do indivíduo e das populações, as hipóteses que o conduzem são também duas: 1) há uma descontinuidade na trajetória da pesquisa de Foucault entre a arqueologia e a genealogia e, apesar desta descontinuidade, é possível isolar o conceito de vida em toda a sua obra e apontar elementos que a atravessam, permitindo caracterizá-la como um deslocamento no pensamento; 2) este conceito é estabelecido por meio do cruzamento de sua dimensão biológica com a política, conferindo-lhes sentidos diferentes correspondentes aos dois níveis de análise. 


\section{9 \\ Descartes e a Experiência da Ordem na Arqueologia}

É, sem dúvida, importante a referência de Foucault à estranheza que o texto de Borges sobre uma certa enciclopédia chinesa suscita. ${ }^{67}$ Foucault transforma a surpresa em crítica demolidora das evidências atribuídas aos saberes e às práticas científicos e institucionais com os quais convivemos muitas vezes, há séculos, sem questionarmos sua necessidade. Assim, ele salienta o mal-estar diante do Outro, evidenciando-lhe o caráter arbitrário; ao mesmo tempo, e às avessas, aponta a arbitrariedade do Mesmo - da Razão.

Na enciclopédia chinesa há desordem, há fragmentos de um grande número de ordens possíveis, que permanecem numa dimensão heteróclita, sem lei (sem ordem) nem geometria (espaço). Borges mostra a desconcertante atopia e afasia da enciclopédia fictícia, que fere a prática milenar do Mesmo e do Outro. Ali, é impossível pensar um solo comum necessário para estabelecer ligações entre os seres classificados (fantásticos, desenhados, pertencentes ao Imperador etc.); é impossível encontrar um solo comum que permita a justaposição ou a ordenação racional dos seres. A desordem é o limite da Razão, o Outro.

Diante do texto de Borges, o que mobiliza Foucault não são as distorções da classificação, mas a suspeita de que existe uma desordem pior do que a incongruência de uma aproximação que não convém. Esta suspeita o conduz a levantar um conjunto de questões históricas: qual o solo comum a partir do qual podemos classificar? Através de que ordem adquiriu-se o hábito de

\footnotetext{
${ }^{67}$ Foucault (2002a: IX) transcreve: "os animais se dividem em: a) pertencentes ao Imperador, b) embalsamados, c) aprisionados, d) porcos de leite, e) sereias, f) fabulosos, g) cães em liberdade, h) incluídos na presente classificação, i) que se agitam como loucos, j) inumeráveis, k) desenhados com um pincel muito fino de pelo de camelo, l) etc., $\mathrm{m}$ ) que acabam de quebrar a casca, n) que de longe parecem moscas".
} 
distribuir as coisas e os seres? Que modalidades da ordem foram reconhecidas, estabelecidas, entrelaçadas com o espaço e o tempo para formar a base positiva de nossos conhecimentos? Quais as condições de possibilidade dos conhecimentos e teorias? Segundo que espaço de ordem se constituíram os saberes? Sobre o fundo de qual a priori histórico ${ }^{68}$ de qual positividade a ordem é pensada numa determinada época?

Nesta investigação, em primeiro lugar, interessa a afirmação foucaultiana de um domínio ou espaço intermediário, obscuro, confuso, difícil de analisar, que manifesta a experiência da ordem e seus modos de ser. Tal domínio é anterior às palavras, às percepções e aos gestos, e só existe na grade de um olhar, de uma atenção, de uma linguagem. Na episteme clássica, o quadro é a configuração de um espaço comum "que permite ao pensamento operar com os seres uma ordenação, uma repartição em classes, um agrupamento nominal, pelo que são designadas suas similitudes e suas diferenças - lá onde, desde o fundo dos tempos, a linguagem se entrecruza com o espaço" (Foucault, 2002a: XII). $\mathrm{Na}$ episteme moderna, o espaço comum vai ter outra configuração.

A originalidade das análises foucaultianas da noção de experiência da ordem e sua relação com o conceito de vida, com os saberes da vida e os efeitos de poder a ele relacionados é, sem dúvida, de grande importância tanto em termos de metodologia, quanto de seus conteúdos; interessa, portanto, o modo pelo qual Foucault os analisa e a maneira pela qual a arqueologia - que se dirige à vida, através da pesquisa situada no nível do saber - se articula com a genealogia ${ }^{69}$ - que considera a vida do ponto de vista político, ao indagar as correlações de forças e as formas de poder que se relacionam com os saberes da vida.

Ao apontar dois "modos de ser da ordem", em As Palauras e as Coisas, a análise de Foucault traça uma ruptura entre os séculos XVIII e XIX. Analisamse, aí, compatibilidades e incompatibilidades entre a disposição clássica da ordem e a nova disposição da ordem na modernidade, quando o quadro

\footnotetext{
${ }^{68}$ Embora Foucault busque uma descrição das condições a priori de emergência dos enunciados, não se trata de condições transcendentais formais. Seria inexato conceber este a priori histórico como um a priori formal, e, ainda que histórico, por ter surgido num dado momento, fosse imóvel e vazio.

${ }^{69}$ Conforme ressalta Machado, o termo genealogia foi introduzido em Vigiar e Punir, e é nesse texto que seu sentido aparece mais claramente. $O$ termo refere-se à idéia de que a questão central de suas pesquisas é o poder como instrumento de análise capaz de explicar a produção dos saberes. A genealogia é uma análise histórica das condições políticas de possibilidade dos discursos. Machado e, como ele mesmo assinala, François Ewald (1978) consideram haver uma ruptura entre a arqueologia e a genealogia.
} 
(espacial) deixa de ser o lugar de todas as ordens possíveis, a matriz de todas as relações, a forma de distribuição de todos os seres, tornando-se apenas "uma película de superfície”.

Foucault procura determinar o a priori histórico que, em cada época, recorta o campo de saber possível da experiência, define o modo de ser dos objetos que nela aparecem, arma o olhar cotidiano de poderes teóricos e define as condições em que é possível fazer um discurso reconhecido como verdadeiro. No século XVIII, quando a positividade do saber é marcada pelas pesquisas e pelos debates científicos sobre a existência dos gêneros e a estabilidade das espécies, o modo de conhecer se define por sua atividade de organizar os elementos visíveis, de definir as variáveis da descrição e de constituir um espaço de vizinhanças, em que todo indivíduo pode ser ordenado.

Ele rejeita as explicações, geralmente assumidas pelas histórias das idéias, é importante insistir, que atribuíram o surgimento da biologia à descoberta de um novo objeto de curiosidade - a vida com seus problemas e as discussões que ela suscita. A este fenômeno elas atribuíram um certo número de causas e diversas manifestações essenciais. O problema crucial destas histórias reside em seu próprio objetivo:

Pretende-se fazer histórias da biologia no século XVIII; mas não se tem em conta que a biologia não existia e que a repartição do saber que nos é familiar há mais de 150 anos não pode valer para um período anterior. E que se a biologia era desconhecida, o era por uma razão bem simples: é que a própria vida não existia. Existiam apenas seres vivos e que apareciam através de um crivo do saber constituído pela história natural. (Foucault, 2002a: 174)

A análise arqueológica busca explicar a positividade que constitui a história natural de um modo totalmente diferente. As pesquisas das descobertas científicas não dão conta, segundo Foucault, das séries de operações complexas que a ciência recobre, ao introduzir a possibilidade de um ordenamento constante num conjunto determinado de representações. No nível arqueológico, a história natural corresponde à constituição de um domínio de empiricidade que pode ser ordenado e descrito, espacialmente, através do quadro. Já a biologia corresponde ao estabelecimento de um domínio de empiricidade que pode ser descrito, não mais através do quadro, mas de acordo com sua historicidade. O saber muda de natureza e de forma; mas, para ele, isto não se deve a uma retificação dos métodos, nem a uma melhor aproximação de seu objeto, nem a melhores modelos de formalização. Não 
se trata de uma passagem dos saberes de uma pré-história para uma espécie de auto-análise da razão, ou de seu progresso. Isto porque o processo de transformação dos saberes deve-se a uma nova organização epistemológica; a questão do progresso das ciências não se aplica à investigação dirigida às diferentes configurações do saber.

É preciso lembrar que a obra de Foucault permite ver, conforme já ressaltado, que esta questão da vida se coloca em termos de uma genealogia, a partir da afirmação de que as ciências biológicas se articulam com outros campos de saber e de práticas (pedagógicos, militares, industriais, médicos) e com as relações de forças, incidindo sobre a vida dos indivíduos e das populações. O nível biológico e o histórico se ligam, de acordo com uma complexidade crescente, à medida que são desenvolvidas tecnologias modernas de poder que têm por alvo a vida. Foucault aponta descontinuidades não só entre a episteme clássica e a moderna, mas também entre as formas de poder exercidas na época clássica e as desenvolvidas na época moderna.

No nível genealógico, as descontinuidades vão ser traçadas de acordo com as condições de possibilidade da constituição dos diferentes modos de relação que se estabelecem entre os saberes e as formas de exercício de poder. A partir do final do século XVIII, se constitui o que Foucault chama de modelo estratégico do poder, cujo objetivo é a normalização. ${ }^{70}$ Sua eficácia deve-se ao entrecruzamento das tecnologias do poder disciplinar com as do biopoder, da disciplina com a norma.

A disciplina se dirige aos indivíduos, a seus corpos, com táticas cujo objetivo é maximizar sua docilidade e utilidade, através da ordenação das multiplicidades humanas. As práticas da época moderna são tomadas por Foucault como produtos de uma confluência de tecnologias desenvolvidas para racionalizar a polícia das populações, de modo que governar implicará produzir e recorrer a novas tecnologias e a saberes que auxiliem na função de gerir a vida da população: "um poder destinado a produzir forças, a fazê-las crescer e a ordená-las mais do que a barrá-las, dobrá-las ou destruílas” (Foucault, 2001a: 128). É o que Foucault (2001 a: 130) denomina biopoder: um poder, cujo "papel mais importante é o de garantir, sustentar, reforçar, multiplicar a vida e pô-la em ordem”. Em História da Sexualidade 1, pode-se ver que, a partir do século

\footnotetext{
${ }^{70}$ De acordo com Castro (2009: 309): "É necessário ressaltar que a descrição de Foucault refere-se a uma sociedade de normalização, não a uma sociedade normalizada. A normalização descreve o funcionamento e a finalidade do poder. A realização de tal objetivo, no entanto, ainda que tenha alcançado uma extensão notável, nem por isso é hegemônica; deve-se enfrentar com os movimentos de luta e questionamento".
} 
XVIII, cada vez mais, os mecanismos de poder se dirigem à vida, ordenando as diferenças humanas. Neste sentido, há um crescente ordenamento, em todas as esferas do social, sob o pretexto de desenvolver o bem-estar.

Quanto a estes dois sentidos, é preciso ressaltar dois aspectos importantes. Primeiro, a amplitude da tese da inexistência da noção biológica de vida e das ciências da vida, até o século XIX. Segundo, a assustadora abrangência atribuída aos poderes exercidos em nossa sociedade, ao se articularem com os saberes que ordenam as multiplicidades no plano da vida dos indivíduos e das populações, através de meticulosas e generalizadoras estratégias de dominação.

Foucault analisa a experiência da ordem na episteme ocidental, traçando uma descontinuidade entre a episteme da Renascença e a da época clássica, e entre esta e a da época moderna.

No início do século XVII, nesse período que chamam barroco, o pensamento cessa de se mover no elemento da semelhança. A similitude não é mais a forma do saber, mas antes a ocasião do erro, o perigo ao qual nos expomos quando não examinamos o lugar mal esclarecido das confusões. 'É um hábito muito freqüente', diz Descartes nas primeiras linhas do Regulae, 'quando se descobrem algumas semelhanças entre duas coisas, atribuir tanto a uma como a outra, mesmo sobre pontos em que elas são na realidade diferentes, aquilo que se reconheceu como verdadeiro somente para uma das duas'. (Foucault, 2002a: 70)

As figuras rigorosas da similitude vão ser esquecidas. Foucault reconhece as dificuldades para demarcar as descontinuidades entre dois domínios do pensamento, pois todo limite é um corte arbitrário num conjunto indefinidamente móvel. A seu ver, para recortar um período e estabelecer, em dois pontos do tempo, rupturas simétricas, fazendo aparecer entre elas um sistema contínuo e unitário, seria necessário, antes de mais nada, responder às seguintes questões: De onde viria sua constituição? A que regime poderiam obedecer, ao mesmo tempo, sua existência e seu desaparecimento? Se tem em sua própria existência a lei de sua coerência, de onde pode vir o estranho que justificaria a recusa do primeiro? Como um pensamento pode se esquivar diante de outra coisa diferente de si mesmo? O que quer dizer, de um modo geral, não mais poder pensar um pensamento, e inaugurar um pensamento novo?

A descontinuidade é definida como o fato de que, em alguns anos, uma cultura deixa de pensar como havia feito até então, e se põe a pensar outra coisa e de outro modo, abrindo, a partir de uma erosão de causa externa, um espaço que é, para o pensamento, um outro lado. No início, a análise 
arqueológica tem de acolher as descontinuidades, ainda obscuras, na ordem empírica evidente em que aparecem. Somente ao longo da análise, elas podem ser determinadas com maior precisão.

Para a arqueologia, interessam as descontinuidades que configuram e delimitam a episteme clássica, cuja figura mais representativa é o pensamento de Descartes. O que torna possível, em seu conjunto, o conhecimento clássico é a maneira específica como se relaciona com a experiência da ordem. As Palavras e as Coisas é uma análise histórica desta experiência. ${ }^{71}$

Foucault analisa não somente de que maneira nossa cultura manifestou que há ordem, mas a que modalidades de ordem as trocas deviam suas leis, os seres vivos suas regularidades, as palavras seu encadeamento e valor representativo. Ele indaga de que maneira as modalidades da ordem foram reconhecidas como positivas para os conhecimentos da gramática e da filologia, da história natural e da biologia, do estudo das riquezas e da economia.

De acordo com Foucault (2002a: XVIII), a cultura determina os códigos da ordem, uma vez que "em toda cultura há, entre o uso dos códigos ordenadores e as reflexões sobre a ordem (ciência e filosofia), a experiência da ordem e de seus modos de ser. Entre o olhar codificado da cultura e o conhecimento da reflexão filosófica e científica, encontra-se esta região mediana - da experiência da ordem - cujo papel é intermediar e liberar a ordem em seu ser puro, instaurando um novo solo epistemológico, condição de possibilidade da representação.

Em outras palavras, de um lado, temos o que Foucault chama de região da cultura, em que a ordem é dada por códigos ordenadores espontâneos, valorativos e imediatos; de outro, temos o pensamento. Entre os dois há uma região mediana - a da experiência da ordem, situada, portanto, entre o imediato e espontâneo da cultura e o mediato do pensamento. O saber se desdobra, passando de uma região à outra, através de dois distanciamentos: o primeiro corresponde a um afastamento da região do imediato da cultura, que opera um distanciamento em relação a si mesma, permitindo-lhe ver-se a

${ }^{71}$ Branco (2009: 283) destaca hipóteses deste livro: "1) todo pensamento, toda prática, toda fala de uma época são coordenadas, em último caso, por um conjunto pequeno e restrito de idéias fundamentais, que o pensador francês intitula por enunciados, e que constituem verdadeiras matrizes anônimas de toda a intelecção deste tempo determinado; 2) os enunciados situam-se numa região mediana entre a teoria e a experiência, e determinam estes dois campos; 3) tais matrizes enunciativas sofrem grandes transformações de tempos em tempos, e modificam toda a configuração de saber, o que faz com que, entre as épocas, diferentes camadas de discursos e práticas se superponham (uma vez que são produtos da influência de diferentes matrizes enunciativas), o que torna possível que se faça, posteriormente, uma arqueologia do saber". 
si mesma e liberar o "ser bruto" da ordem, seu "ser puro" da ordem, condição arqueológica de possibilidade dos saberes da época clássica. O segundo distanciamento opera uma dobra do pensamento sobre si mesmo, instaurando a explicação, a crítica e a reflexão; a ciência e a filosofia são fruto desta dobra. Elas explicam por que há ordem, reconhecem e criticam o ser da ordem, determinando o solo positivo, reconhecido, das interpretações e das teorias, sua positividade.

Descartes representa a novidade do pensamento na época clássica ao universalizar o ato da comparação - todo conhecimento, afirma ele, é obtido pela comparação de duas ou várias coisas entre si - que depende, em última instância, da ordem. No cartesianismo, existem duas formas de comparação: a da medida e a da ordem. Podemos medir grandezas ou multiplicidades, quer dizer, grandezas contínuas ou descontínuas; mas, nos dois casos, a operação de medir supõe que consideremos, antes de mais nada, o todo e que o dividamos em partes. Compará-las exige que as analisemos, a partir de uma unidade comum. A comparação efetuada pela medida se relaciona com as relações aritméticas de igualdade e de desigualdade. A medida permite analisar o semelhante, segundo a forma calculável da identidade e da diferença.

Quanto à ordem, ela se estabelece, no cartesianismo, sem referência a uma unidade exterior: "reconheço, com efeito, qual é a ordem entre A e B sem nada considerar senão esses dois termos extremos"; só podemos conhecer a ordem das coisas "na sua natureza isoladamente", separando a mais simples, depois a mais próxima, para que possamos aceder, necessariamente, e por graus, às coisas mais complexas. Enquanto a comparação por medida exige, primeiramente, uma divisão, depois, a aplicação de uma unidade comum, a comparação por ordem é um ato simples, que permite passar de um termo a outro, em seguida, a um terceiro, e assim sucessivamente, através de um movimento "absolutamente ininterrupto" (Descartes apud Foucault, 2002a: 73).

O primeiro termo da série é uma natureza que pode ser intuída de modo independente, os outros termos são estabelecidos de acordo com diferenças crescentes, segundo graus, a partir dos elementos mais simples. Ora, podemos reunir a medida das grandezas (continuidades) e das multiplicidades (descontinuidades) através da ordenação, pois os valores da aritmética são sempre ordenáveis segundo uma série. A multiplicidade das unidades pode, então, "dispor-se segundo uma ordem tal que a dificuldade, que pertence ao conhecimento da medida, acabe por depender somente da consideração da ordem" (Descartes apud Foucault, 2002a: 74). 
A crítica cartesiana da semelhança abandona o pensamento do século XVI; ela não consiste numa inquietação renascentista do pensamento diante de si mesmo que começa a se desvencilhar de suas figuras mais familiares; ela se constitui pela exclusão da semelhança como experiência do saber e pela denúncia de seu caráter confuso que precisa ser analisado em termos de identidades e diferenças, de medidas e ordem. Se Descartes recusa a semelhança, não é excluindo do pensamento racional o ato da comparação, nem procurando limitá-lo, mas, ao contrário, universalizando-o e dando-lhe sua forma mais pura. Foucault mostra que, segundo Descartes, é pela comparação que encontramos a figura, a extensão, o movimento e outras semelhanças - quer dizer, as naturezas simples - em todos os sujeitos em que podem se apresentar.

Foucault desenvolve este argumento a partir da análise de um aspecto da teoria do conhecimento formulada por Descartes. Numa dedução do tipo “todo A é B, todo B é C, então A é C", é claro que o espírito "compara entre si o termo procurado e o termo dado, a saber A e C, através dessa relação segundo a qual um e outro são B". Por conseguinte, se se coloca de lado a intuição de uma coisa isolada, pode-se dizer que todo conhecimento "se obtém pela comparação de duas ou várias coisas entre si” (Foucault, 2002a: 72). Contudo, só há conhecimento verdadeiro ou por intuição, quer dizer, por um ato singular da inteligência pura e atenta, ou por dedução, que liga as evidências entre si. Mas como a comparação, exigida para quase todos os conhecimentos e que, por definição, não é uma evidência isolada nem uma dedução, poderá, na episteme clássica, autorizar um pensamento verdadeiro? Esta questão será fundamental, pois "quase todo o trabalho da razão humana consiste, sem dúvida, em tornar essa operação possível” (Descartes apud Foucault, 2002a: 72). Deixando de lado o caso da intuição, o conhecimento é, de modo geral, um ato de comparação. A comparação, na episteme clássica, não tem a função de revelar a ordem do mundo, mas se faz segundo a ordem do pensamento e indo, diretamente, do simples ao complexo, sem relação com o real. Portanto, conhecer é comparar; comparar é ordenar; como a ordenação se funda na ordem racional, conhecer é analisar.

Pode-se ver em As Palavras e as Coisas, que toda a episteme da cultura ocidental se encontra, assim, modificada em suas disposições fundamentais a partir de Descartes que inaugura a episteme clássica. ${ }^{72}$ Mais tarde, Foucault

$\overline{72}$ Enquanto o saber da episteme da Renascença se constitui pelo ato de estabelecer analogias entre as coisas e as palavras (as coisas são signos a serem interpretados), o saber da episteme clássica se constitui pela ordenação em quadros das identidades e diferenças, no nível da representação (a idéia se relaciona a outra idéia e não à coisa). 
mostrará a ruptura entre a episteme clássica e a moderna, conforme já assinalado. Esta ruptura é traçada sob a insígnia da rejeição foucaultiana às histórias das idéias, pois elas denominam esta época de racionalista, dizem que o século XVII marca o desaparecimento de velhas crenças e a entrada da natureza na ordem científica, definem o racionalismo clássico pela tentação de tornar a natureza mecânica e calculável, ressaltam o esforço de matematização da natureza (constante e contínuo na astronomia e em parte da física, esporádico nos outros domínios) e as interpretações mecanicistas. Porém, nada disto esclarece o que ocorreu. Nenhuma destas explicações deve ser confundida com a relação que todo saber clássico, em sua forma mais geral, mantém com a mathesis, compreendida como ciência universal da medida e da ordem.

O fundamental, para a episteme clássica, não é nem o sucesso ou o fracasso do mecanicismo, nem o direito ou a impossibilidade de matematizar a natureza, mas a relação com a mathesis, que, até o final do século XVIII, permanece constante e inalterada. Esta relação apresenta duas características essenciais. A primeira é que as relações entre os seres serão pensadas sob a forma da ordem e da medida, mas com um desequilíbrio fundamental, pois é sempre possível reduzir os problemas da medida aos da ordem. É por isso que a relação de todo conhecimento com a mathesis se dá com a possibilidade de estabelecer entre as coisas, mesmo não mensuráveis, uma sucessão ordenada. É neste sentido que, ao conhecimento, se atribui um valor de método universal. Durante a época clássica, estabeleceu-se o projeto de um método universal de análise para produzir certezas perfeitas, através da ordenação das representações e dos signos, capaz de espelhar a ordem do mundo e do ser, que, por sua vez, tinha uma ordem universal. $\mathrm{O}$ método universal de análise poderia dispor, de um modo claro e progressivo, as representações que nos dariam a imagem da verdadeira ordem do mundo.

A segunda característica é que esta relação com a mathesis como ciência geral da ordem não significa uma absorção do saber pelas matemáticas, nem o fundamento nelas de todo conhecimento possível. Ao contrário, em correlação com a mathesis, aparece, de acordo com Foucault, um certo número de domínios empíricos que ainda não haviam sido formados. Em nenhum destes domínios é possível encontrar traços de mecanicismo nem de matematização; no entanto, todos se constituíram sobre o fundo de uma 
ciência possível da ordem. ${ }^{73}$ Foi a partir dela que apareceram as novas empiricidades da época clássica: a gramática geral, a história natural e a análise das riquezas, ciências da ordem no domínio das palavras, dos seres e das necessidades, respectivamente. $\mathrm{O}$ projeto de uma ciência geral da ordem, a teoria dos signos para analisar a representação e a disposição em quadros ordenados das identidades e diferenças constituem um novo espaço de empiricidade na época clássica.

Quando se trata de naturezas simples, é a uma mathesis, cujo método universal é a álgebra, que se recorre na época clássica. Quando se trata de ordenar naturezas complexas (as representações em geral, tal como se dão na experiência), é preciso constituir uma taxonomia e, para fazê-lo, instaurar um sistema de signos. Os signos são para a ordem das naturezas compostas o que a álgebra é para as naturezas simples. Mas, na medida em que as representações empíricas devem poder ser analisadas como naturezas simples, a taxonomia começa a se relacionar, inteiramente, à mathesis; em troca, como a percepção das evidências é apenas um caso particular da representação em geral, podemos dizer que a mathesis é apenas um caso particular da taxonomia.

Por toda a episteme clássica, o espaço do quadro foi percorrido, sem cessar, desde as formas calculáveis da ordem até as análises das representações mais complexas. Para estabelecer o grande quadro das espécies, dos gêneros e das classes, foi necessário que a história natural utilizasse, criticasse, classificasse e, finalmente, reconstituísse uma linguagem, cuja condição de possibilidade residisse, exatamente, na continuidade da natureza. As coisas e as palavras são rigorosamente entrecruzadas no quadro; tanto é assim que a natureza só se mostra através da grade das denominações, sem tantos nomes, ficaria muda e invisível. Eis porque a história natural não pode, para Foucault - e esta é uma das teses principais de As Palavras e as Coisas - se constituir como biologia: até o final do século XVIII, com efeito, a vida não existe; apenas os seres vivos, que formam uma ou, antes, diversas classes na série de todas as coisas do mundo. Só podemos falar de vida na época clássica como de um caráter - no sentido taxonômico - na distribuição universal dos seres.

\footnotetext{
${ }^{73}$ Machado (1981: 137) assinala a originalidade dessa interpretação: "a história natural não escapava dos princípios estabelecidos por Descartes, nem revelava uma insuficiência enquanto saber: tinha um lugar determinado na configuração dos saberes clássicos, que são fundamentalmente conhecimentos da ordem. Só que essa ordenação pode se realizar tanto através de uma mathesis, em sentido estrito - isto é, o conhecimento das igualdades e das desigualdades, que tem validade quando se trata de natureza simples (...) e que tem como instrumento a álgebra - quanto de uma taxonomia, isto é, que deve ser exercido enquanto se trata de naturezas complexas, (...) cujo método não é mais matemático, mas o próprio sistema de signos da linguagem natural".
} 
Habitualmente, os seres da natureza são divididos em três classes: os minerais, os vegetais, os animais. Quanto à vida, afirma Foucault, pode-se fazê-la deslizar pelas três. A vida é uma categoria que, como todas as outras, está sujeita a imprecisões, quando se quer fixar suas fronteiras. Mas o corte entre o vivo e o não-vivo não é um problema da episteme clássica. O naturalista é o homem do visível estruturado e da denominação, não da vida. A história natural não pode ser ligada a uma filosofia da vida; ela está ligada à teoria das palavras. De acordo com Foucault, a noção de vida só aparece na história do pensamento, no início do século XIX. Vida, trabalho e linguagem são as três novas empiricidades da episteme moderna. O final do século XVIII marca o aparecimento de uma nova maneira de conhecer, que divide, mais uma vez, a episteme do mundo ocidental. $\mathrm{O}$ pensamento moderno se caracteriza pela síntese e pela impossibilidade de fundá-la no espaço da representação, sem, contudo, abandoná-la inteiramente.

Através do recuo histórico para determinar as condições de possibilidade do surgimento da episteme moderna, Foucault chega à descontinuidade no modo de ser da ordem, marcando o aparecimento de uma nova positividade no espaço geral do saber, no final do século XVIII. Nesta passagem, o papel da representação muda:

A análise pode mostrar a coerência que existiu, ao longo de toda a idade clássica, entre as leis da representação e as da linguagem, as das ordens naturais e as da riqueza e do valor. É esta configuração que, a partir do século XIX, muda inteiramente; a teoria da representação desaparece como fundamento geral de todas as ordens possíveis; a linguagem como quadro espontâneo e esquadrinhamento primeiro das coisas, como terreno indispensável entre a representação e os seres, se apaga. (Foucault, 2002a: XX)

É quando as coisas obedecem às leis de seu próprio devir e não mais às leis da representação. À medida que as coisas se voltam sobre si mesmas, sobre sua própria historicidade, buscando seu princípio de inteligibilidade e abandonando o espaço da representação, o homem aparece, pela primeira vez, no campo do saber ocidental, constituindo-se, então, as ciências do homem. Mas o homem só aparece, indiretamente, como um dilaceramento na ordem das coisas, cuja configuração Foucault analisa, a partir das três empiricidades próprias à episteme moderna: a vida (do homem que vive), a linguagem (do homem que fala) e o trabalho (do homem que trabalha). Enquanto é a representação que o homem faz dos objetos empíricos que constitui o objeto 
das ciências do homem, são os mecanismos, os funcionamentos econômicos, biológicos e filológicos que constituem os objetos das ciências empíricas. Os homens constroem representações sobre a vida, o trabalho e a linguagem por que vivem, trabalham e falam.

A pesquisa arqueológica desenvolvida em As Palavras e as Coisas é uma história da ordem que busca o fundo segundo o qual nós pensamos numa determinada época. Do ponto de vista da ordem, o fundo segundo o qual pensamos hoje não tem o mesmo modo de ser dos clássicos. A quase continuidade no nível das idéias e dos temas destas duas épocas - a clássica e a moderna - é apenas um efeito de superfície; no nível arqueológico, afirma Foucault, vemos que a modalidade da ordem foi profundamente alterada. É a partir desta alteração que vamos conhecer o conceito de vida.

Os limites temporais da história arqueológica são marcos traçados a partir dos princípios de organização dos discursos, através do estabelecimento da ordem interna constitutiva dos saberes em sua positividade; Foucault o faz, concebendo a episteme como critério desta organização dos discursos. É neste sentido que as análises arqueológicas permitem analisar compatibilidades e incompatibilidades entre saberes, a partir da configuração de suas positividades. No nível arqueológico, conforme afirma Foucault, o sistema das positividades mudou, de uma forma maciça, na passagem do século XVIII para o século XIX. Para ele, foi possível, através da arqueologia, definir sistemas de simultaneidade e uma série de mutações suficientes e necessárias para circunscrever o início de uma positividade, de uma série de descontinuidades.

O pensamento de Kant representa esta nova forma. A crítica kantiana marca o aparecimento das sínteses objetivas e da analítica da finitude, colocando em questão o próprio espaço da representação. Sua filosofia transcendental toma o sujeito como o fundamento de toda síntese possível, assinalando os limites da representação. Em Kant, é clara a separação entre o empírico e o transcendental, pois o sujeito - condição a priori de possibilidade de todo conhecimento - que não é empírico, não se dá à experiência. No final do século XVIII, o abandono do espaço da representação transforma o saber, possibilitando o surgimento do conhecimento como síntese objetiva, em que se constituem as ciências empíricas. A biologia surge como conhecimento sintético - e não analítico - da vida. Tal mudança é atribuída à nova configuração da coerência interna da episteme. Foucault se dedica a comparar suas duas configurações arqueológicas. Quanto à questão da vida, veremos uma descontinuidade que estabelece uma profunda mudança na forma do saber, 
a partir da qual devemos caracterizá-lo em dois sistemas que podemos esquematizar do seguinte modo:

1) Época Clássica (século XVI - até final do século XVIII): o saber sobre os seres naturais é a história natural que estabelece ordens, a partir da coerência interna entre as leis da teoria da representação e as das teorias da história natural; os elementos a ser ordenados são os caracteres taxonômicos definidos por sua forma visível. A principal ferramenta que permite o desenvolvimento do método de ordenação é o signo. A função do pesquisador consiste em fazer uma descrição artificial daquilo que se vê, através da criação de uma linguagem artificial e uma ordem convencional dos signos. Todo saber se organiza, em última instância, em termos de uma ordenação.

Com Descartes, desenvolve-se o princípio da comparação por identidade e diferenças e o princípio da correta ordenação dos elementos (do mais simples ao mais complexo); a ferramenta privilegiada será o signo; o papel do homem será esclarecer a ordem do mundo, através da análise das representações. $\mathrm{O}$ conhecimento será vinculado a um quadro, considerado o lugar de todas as ordens possíveis, a matriz de todas as relações, a forma de distribuição de todos os seres; o quadro constitui a ordem que se oferece ao olhar de superfície permitindo operar um esquadrinhamento permanente das distinções. A partir do momento em que se considerou garantido que a linguagem, por sua própria natureza, torna possível a representação, a função do homem de relacionar as representações e as coisas não é mais problematizada.

2) Época Moderna (a partir do final do século XVIII - início do século XIX): inaugurada com Kant e a filosofia do sujeito, a partir da qual o homem será sujeito e objeto ao mesmo tempo. Coloca-se a questão da finitude: o homem será conhecido pela sua finitude, porque é um ser finito; aquele que passa e perde sua vida escapando da iminência da morte. Agora, já não importa tanto a análise das representações; o quadro será apenas uma "película de superfície", apenas um "brilho superficial sobre a profundidade". O que vai aparecer é a obrigação de abrir, para além do sujeito e do objeto, os "quase-transcendentais" - que são a vida, o trabalho e a linguagem -, aos quais correspondem, respectivamente, a biologia, a filologia e a economia. Foucault aponta, assim, uma descontinuidade em relação à história natural, à gramática e à análise da riqueza e do valor que se constituem na episteme clássica.

A biologia estuda os órgãos e as funções a partir não mais da representação, mas de uma coerência entre a historicidade e as teorias das ciências empíricas. Ao abandonar o espaço visível de representação, esta nova disposição do saber 
tem, como princípio de inteligibilidade, o devir. Suas diferentes disposições aparecem nos trabalhos de investigação da natureza de Jussieu, naturalista clássico e nos trabalhos de investigação da vida de Cuvier, biólogo moderno.

Jussieu procede através de uma classificação rigorosa, de acordo com as regras de subordinação dos caracteres; uma classificação unidimensional (unidade de plano) que estabelece identidades e diferenças justapostas, de modo que o Mesmo e o Outro. pertencem ao mesmo espaço. Nele, as variáveis são independentes e percorridas pela linguagem e pelo olhar de superfície. A vida aparece como um recorte, uma simples fronteira classificatória. O importante é o ser vivo considerado como localidade da classificação para estabelecer uma grande ordem natural. Trata-se de uma noção taxonômica dos seres vivos que formam um conjunto contínuo. A disposição epistemológica, desenhada pelo quadro, e seu espaço contínuo são fundamentais. No quadro, o devir só pode ocupar um lugar intermediário e mensurável pelas exigências do conjunto. A teoria da história natural não pode ser dissociada da teoria da linguagem. Isto porque, em sua disposição fundamental, este saber ordena o conhecimento dos seres de acordo com a possibilidade de representá-los num sistema de nomes. A história natural é contemporânea da linguagem - bem construída e, sobretudo, universalmente válida; ela pertence ao mesmo nível do jogo espontâneo que analisa as representações na lembrança, fixa seus elementos comuns, estabelece signos a partir deles e impõe nomes. Classificar e falar se originam no mesmo espaço aberto pela representação.

No final do século XVIII, uma nova configuração aparecerá abalando o velho espaço da história natural. Por um lado, a crítica se desloca e se desprende do solo onde havia nascido. Kant, ao isolar a causalidade, ao invés de estabelecer relações de identidade e diferença no contínuo das similitudes, faz aparecer o problema inverso da síntese do diverso.

Assim, a questão da crítica reporta o julgamento, a existência e o gênero, obtidos pela análise das representações, à possibilidade de ligar as representações entre si, à possibilidade do direito de nomear como fundamento da articulação nominal da proposição com o verbo. Deste modo, Kant generaliza a crítica, dirigindo sua investigação às condições de possibilidade de todo conhecimento. Em contrapartida, a vida torna-se autônoma com relação aos conceitos da classificação, escapando da relação que, no século XVIII, constituía o saber da natureza.

Conforme mostra Foucault, Cuvier libertou a subordinação dos caracteres de sua função taxonômica, fazendo-os entrar, além de toda classificação 
eventual, nos diversos planos de organização dos seres vivos. O espaço dos seres vivos gira em torno da noção de organização como um ser abstrato, suscetível de numerosas formas. Tudo que apareceu no esquadrinhamento da história natural (gêneros, espécies, indivíduos, estruturas, órgãos - na acepção clássica), tudo o que se mostrou ao olhar toma uma forma nova. A arqueologia permite mostrar que o espaço geral do saber, então, não é mais o das identidades e diferenças, o das ordens não quantitativas de uma taxonomia geral, nem de uma mathesis do não mensurável, mas um espaço constituído de organizações, que são organizações internas dos elementos cujo conjunto assegura uma função.

As organizações são descontínuas e, por isso, não podem formar um quadro de simultaneidades sem rupturas. A vida não tem gradação: isola formas que se entrelaçam entre si. A vida consiste no enigma de uma força inacessível em sua essência, tangível apenas nos esforços para se manifestar e se manter; o ser biológico se regionaliza e se autonomiza. Algumas organizações são de um mesmo nível, enquanto outras traçam séries ou seqüências lineares, fazendo surgir, como princípios organizadores deste espaço de empiricidades, a analogia e a sucessão. A partir do século XIX, a história desdobra as analogias que aproximam, umas às outras, as distintas organizações, numa série temporal. A história cede espaço para as organizações analógicas, do mesmo modo que a Ordem abria o caminho das identidades e diferenças sucessivas. Ela constituirá o pensamento da modernidade. O espaço visível do quadro, portanto, perde sua função.

Quanto aos órgãos, que agora são compreendidos como elementos ou grupos de elementos distintos que o olhar pode articular quando percorre o corpo dos indivíduos, eram definidos na época clássica, por sua função e estrutura. Cuvier faz uma inversão: submete a disposição do órgão à soberania da função. As funções são em número relativamente reduzido: respiração, digestão, circulação, locomoção. A diversidade visível das estruturas não emerge mais sobre a base de um quadro de variáveis, mas sobre o fundo de grandes unidades funcionais. Aparecem semelhanças onde não há nenhum elemento idêntico; aqui, a semelhança se constitui pela passagem à evidente invisibilidade da função.

A partir de Cuvier, a função, definida por sua forma não perceptível do efeito a ser atingido, vai permitir relacionar, entre si, conjuntos de elementos desprovidos de identidade visível. Aquilo que, para o olhar clássico, eram simples diferenças justapostas às identidades, deve, agora, 
ser ordenado e pensado a partir de uma homogeneidade funcional que o sustenta em segredo. Há história natural, afirma Foucault, quando o Mesmo e o Outro. pertencem a um único plano. Na biologia, a unidade de plano começa a se desfazer, e as diferenças surgem sobre o fundo de uma identidade mais profunda e mais séria. Esta referência à função diz respeito a sistemas comandados uns pelos outros, e o problema da importância recíproca se coloca de novo.

Assim, o biológico reflete-se no político: "o fato de viver não é mais esse sustentáculo inacessível que só emerge de tempos em tempos, no acaso da morte e de sua fatalidade: cai, em parte, no campo de controle do saber e de intervenção do poder (Foucault, 2001a: 134). 


\section{0 \\ Representação e Constituição do Objeto na Arqueologia}

Desde O Nascimento de Clínica, a análise histórica das noções de representação e de objeto de conhecimento é central na arqueologia. Em primeiro lugar, porque afirma o primado da representação como fundamento do saber clássico; em segundo lugar, na medida em que aponta a abertura deste saber a uma nova forma, a partir do vazio deixado pela retirada da pura representação do campo do saber, considerada como a própria configuração do modo de conhecer da época clássica. Finalmente, por considerar que, na modernidade, o pensamento só pode se constituir de um novo modo ao contornar o primado da representação, tomando-a como objeto de saber e não mais como sua própria forma.

Tal afirmação explicita-se através do estabelecimento de continuidades e descontinuidades $^{74}$ (Foucault, 2002a), no nível do saber, entre as epistemes: ${ }^{75}$ a clássica, espaço homogêneo, em que a filosofia e as ciências - não só as ciências matemáticas e as da natureza, mas as das empiricidades como a história natural, a gramática geral e a análise das riquezas - se situam no mesmo nível de saber; e a moderna, em que a filosofia e as ciências - empíricas como a biologia, a filologia ou lingüística e a economia e as ciências humanas - se desnivelam. Portanto, se as descontinuidades são, para Foucault, indispensáveis

\footnotetext{
${ }^{74}$ Talvez a melhor definição de descontinuidade em As Palavras e as Coisas consista na idéia do fato de que, em alguns anos, às vezes, uma cultura deixa de pensar como havia feito até então, e pensa uma outra coisa e de uma outra maneira, ou ainda, como aquilo que se abre sobre um espaço que está, para o pensamento, no outro lado, mas onde, contudo, não deixou de pensar desde a origem.

75 Podemos compreender episteme como o espaço geral do saber, solo em que se enraízam as positividades, com uma historicidade própria, apresentando continuidades e descontinuidades.
} 
para definir os limites temporais de uma episteme e, nela, o aparecimento de nova relação da representação com os objetos, de novas formas dos saberes, são as continuidades entre os diferentes saberes de uma determinada época que delimitam seu espaço geral, são as relações de diferentes ciências entre si e a filosofia que permitem traçar a configuração geral da episteme.

De acordo com Foucault, é a partir da abertura da episteme clássica a uma nova disposição do saber, a partir da introdução, no início do século XIX, do tema transcendental no pensamento filosófico e da descoberta do empírico pelas ciências empíricas, que, para ele, inaugura-se o saber moderno. Com a separação do transcendental e do empírico, a representação deixa de constituir o campo geral do pensamento, sua própria configuração, tornando-se objeto. O espaço do saber apresenta-se, então, heterogêneo, dividido em dois níveis - o das ciências propriamente empíricas, que tratam do objeto, e o da filosofia transcendental, que se dirige ao sujeito. É quando o homem pode aparecer, pela primeira vez na história do Ocidente, como sujeito e objeto ao mesmo tempo. Kant teria, de acordo com Foucault, fundado a modernidade, ao estabelecer a distinção entre o empírico e o transcendental. Entretanto, teria formulado a questão antropológica "o que é o homem?", a partir de que se estabelece a confusão entre o empírico e o transcendental, que confere ao pensamento moderno seu caráter ambíguo e antropológico.

Para elucidar as dificuldades derivadas de tais afirmações, é preciso analisar o papel de Kant em As Palavras e as Coisas, através das noções de representação e objeto, de empírico e transcendental, na arqueologia, considerando-a não como parte de um sistema unitário de pesquisa, mas como uma etapa - com seus conceitos, seu método, seus objetivos específicos - em sua trajetória. Para analisar este tema, é preciso, antes de mais nada, abandonar a aparente necessidade de unidade e de totalidade da obra filosófica. É necessário renunciar à exigência de correlações entre noções e objetivos nas diferentes épocas do pensamento de Foucault. Sem esta renúncia, corre-se o risco das dificuldades estéreis para este tema, como as que dizem respeito à exigência de sistemas teóricos em filosofia e ao fracasso das explicações tardias, verdadeiras ilusões retrospectivas que não se justificam no caso da arqueologia. Isto porque os conceitos ora tratados têm uma dinâmica singular, específica à forma de problematização da arqueologia em sua fase final.

Tais exigências justificariam críticas, como as de Béatrice Han, de confusão e inconsistência na crítica de Foucault à modernidade. Entretanto, apesar da presença de pontos menos claros em seu pensamento em relação ao papel de 
Kant e apesar da descontinuidade entre a arqueologia e o pensamento que a sucede - que, pela interrupção do uso de conceitos arqueológicos, dificulta ainda mais seu esclarecimento -, a posição de Foucault é clara. Por um lado, ao considerar Kant o limiar da modernidade, termina por mostrar que a filosofia kantiana não cai no "sono antropológico" das filosofias modernas por ele rejeitadas; por outro, ao responder à questão kantiana "o que é o homem?" com a hipótese da morte do homem, o pensamento foucaultiano pode escapar, como o de Nietzsche, do antropologismo.

Sem dúvida, é preciso levar em conta a resposta de Foucault às acusações de que seus deslocamentos são tentativas de fugir das dificuldades que the são colocadas; de que às objeções que lhe são feitas, ele reage mostrando que elas não indicam, realmente, o ponto de vista no qual se situam. Contudo, se quisermos aprender a grande lição de Foucault, temos de levar a sério sua resposta de inspiração nietzschiana:

Ora, vocês imaginam que eu faria tanto esforço e teria tanto prazer, vocês acreditam que eu teria me obstinado, cabeça baixa, se eu não preparasse - com uma mão um pouco febril - o labirinto por onde me aventurar, por onde deslocar meu propósito, abrir-lhe subterrâneos, mergulhá-lo longe de si mesmo, encontrar-lhe desaprumos que resumem e deformam seu percurso, por onde perder-me e aparecer finalmente com olhos que não terei mais que encontrar. Mais de um, como eu, sem dúvida, escreve por não ter mais rosto. (Foucault, 1969: 28)

\section{REPRESENTAÇÃO E VIDA}

É com o objetivo de descrever, no nível arqueológico, a constituição dos saberes sobre o homem na modernidade que Foucault estuda a constituição dos saberes específicos, como a biologia, a economia e a filologia. Enquanto a noção de vida se institui como um objeto específico na época moderna, a de representação constitui o campo geral do pensamento clássico, sua própria configuração.

Ao apontarem uma descontinuidade entre a biologia inaugurada por Cuvier, estudo da vida na episteme moderna, e a história natural representada por Jussieu, estudo dos seres vivos na episteme clássica, Foucault, Canguilhem e Jacob traçam uma nova historiografia da biologia. É pela análise de rupturas no modo da relação da representação com os seres empíricos que eles explicam o surgimento da biologia no início do século XIX. Eles analisam a 
mudança radical no modo de conhecer o vivo, através de um recuo histórico até a época clássica, tomando o pensamento cartesiano como emblemático da concepção de saber não da modernidade, mas da época clássica, quando o conhecimento se torna ordenação de idéias. Atribuem a Descartes e a partir dele, não só o fundamento da filosofia e da matemática e da física, mas o da história natural.

A arqueologia aponta, ainda, no cartesianismo, o fundamento da análise das riquezas e da gramática. No nível arqueológico, não há, na época clássica, diferença entre os saberes científicos e a filosofia; todos são conhecimentos analíticos, são análises que se passam no nível da representação, cujos objetos são as representações a serem ordenadas, nomeadas, classificadas; ciência e filosofia diferenciam-se apenas em termos de maior ou menor generalidade.

O saber da história natural tem como objeto os seres vivos e se constitui como análise da representação, fundada na ciência universal da ordem, cujo instrumento é o sistema de signos. Para Foucault, a história natural não pode se constituir, progressivamente, como uma ciência empírica moderna como a biologia. Isto porque, até o final do século XVIII, não existem nem a noção de vida como objeto empírico, nem a própria noção de objeto empírico. Existem apenas as representações e os seres vivos, os quais são representações, espécies ideais, que formam uma ou várias classes hierarquizadas na série de todas as coisas do mundo, na grande ordem natural, cujo sentido é exclusivamente taxonômico.

Enquanto a história natural insere-se na constituição de um domínio de empiricidade ordenado e descrito, espacialmente, através das representações, a biologia corresponde ao estabelecimento de um domínio empírico externo a elas. Na modernidade, a representação é um fenômeno que pertence às próprias coisas e não mais às idéias. A biologia ordena os órgãos a partir de uma coerência entre a organização interna da vida e a historicidade. A história torna-se o modo de ser fundamental do que é empírico, do que é dado à experiência, impondo suas leis ao conhecimento.

$\mathrm{Na}$ episteme moderna, o objeto é empírico, pesquisado como mecanismo e funcionamento, como um modo específico de existência, leis próprias e um espaço interno que é exterior à representação. A representação, como forma de saber, não pode fornecer o conhecimento deste objeto, pois se mantém em seu exterior. A representação é, então, um fenômeno de ordem empírica que se efetua no homem, como produto da consciência e efeito aparente dos 
objetos concretos, correspondendo, de um modo mais ou menos claro, às próprias coisas.

O espaço deste saber se constitui de organizações que são internas aos elementos de conjuntos funcionais. A partir do século XIX, as analogias estabelecidas pela função se desdobram, aproximando as distintas organizações numa série temporal. A história abre espaço às organizações analógicas, do mesmo modo que a ordem abria às identidades e diferenças sucessivas na época clássica. Cuvier submete a disposição do órgão à soberania das funções, que, ao contrário das infinitas formas visíveis da história natural, se reduzem a respiração, digestão, circulação e locomoção. A função é invisível e será definida a partir do efeito a ser produzido pelos órgãos; ela vai permitir relacionar, entre si, conjuntos de elementos desprovidos de identidade visível. Aquilo que, para o olhar clássico, eram simples diferenças justapostas às identidades, deve agora ser pensado a partir de uma unidade funcional que o sustenta em segredo - a vida.

Segundo Foucault, foi do deslocamento operado por Kant em direção ao conhecimento do objeto empírico, como a vida, por exemplo, que nasceu a reflexão 'semipositiva' e 'semifilosófica' sobre o homem em sua forma de antropologismo e de humanismo. Pois, trata-se de um saber sobre o homem que representa a vida em sua finitude - sua existência corpórea, a necessidade do trabalho e o sentido das palavras - reduplicando os saberes empíricos nas ciências do homem. Constituem-se, portanto, como uma analítica da finitude a partir das transformações do saber, que deram nascimento, ao mesmo tempo, às ciências empíricas e a um tipo de filosofia que Foucault critica como de filosofia do mesmo, que pertence a um pensamento fundado na confusão do transcendental e do empírico.

\section{ESPAÇO DO SABER NA MODERNIDADE}

Para Foucault, Kant é o limiar da modernidade. Ele é o primeiro a interrogar a representação não mais segundo o movimento indefinido, que vai do elemento simples a todas as suas combinações possíveis, mas a partir de seus limites de direito. A crítica "sanciona assim, pela primeira vez, este acontecimento da cultura européia que é contemporâneo do fim do século XVIII: a retirada do saber e do pensamento para fora do espaço da representação. Este é então posto em questão no seu fundamento, na sua origem e nos seus limites" (Foucault, 2002 a: 334). 
No final do século XVIII, a ordem das multiplicidades empíricas não pode mais se fundar, somente, sobre a reduplicação da representação com relação a si mesma, pois colocam-se condições exteriores a ela; não é mais possível justificar os elos das representações através da composição ou decomposição, nem da análise em identidades e diferenças, já que, como vimos no exemplo da vida, suas condições encontram-se no volume próprio às coisas que escapam, em sua verdade fundamental, do espaço do quadro. Na modernidade, a representação é questionada no ser mesmo daquilo que é representado. De um lado, colocam-se as coisas, com sua organização própria, suas nervuras secretas, o espaço que as articula, o tempo que as produz; de outro, a representação, pura sucessão temporal, em que as coisas se anunciam, sempre parcialmente, ao conhecimento.

Foucault delineia os limites da episteme clássica, do ponto de vista de cada uma das ciências 'empíricas' e da filosofia, para explicitar o lugar a partir do qual será possível o surgimento de uma nova forma de saber. Trata-se de um acontecimento uniforme no espaço do saber, uma mudança na relação da representação com aquilo que nela é dado. No capítulo "Os limites da representação”, Foucault (2002a), estuda a representação em vias de perder o poder de definir um modo de ser único, comum, às coisas e ao conhecimento, determinando, nos saberes específicos, pontos limítrofes em que noções constitutivas da modernidade aparecem ainda enraizadas no solo epistemológico clássico, pois há uma disposição do saber que ainda não está definitivamente configurada, no final do século XVIII. É o caso de Smith, Jussieu e Jones que utilizaram, respectivamente, as palavras trabalho, organização e sistema gramatical, sem, contudo, sair do espaço do quadro, nem contornar a visibilidade das coisas, nem escapar à representação que se representa.

A esta configuração ambígua corresponde, segundo Foucault, uma dualidade filosófica que indica o fim da episteme clássica. A Ideologia e a crítica coexistem, porém as duas formas de pensamento são exteriores uma à outra, a primeira pertencendo à episteme clássica e a segunda à moderna. Têm o mesmo ponto de aplicação, a relação das representações entre si, mas, enquanto a crítica a interroga em suas condições, a Ideologia estende a reflexão por todo o campo do conhecimento - desde as impressões originárias até a economia política, passando pela lógica, a aritmética, as ciências da natureza e a gramática -, tentando retomar, na forma da representação, isto mesmo que está em vias de se constituir fora dela. Neste sentido, para Foucault, ela é a última das filosofias clássicas. Na crítica, a relação das representações entre si é interroga- 
da naquilo que a torna possível em sua generalidade, para o estabelecimento de sua forma universalmente válida ao nível das condições da representação. Assim, Kant contorna a representação, para se dirigir àquilo mesmo a partir de que toda representação pode ser dada:

somente os juízos da experiência ou constatações empíricas podem fundar-se sobre os conteúdos da representação. Qualquer outra ligação, para ser universal, deve fundar-se para além de toda experiência, no a priori que a torna possível. Não que se trate de um outro mundo, mas das condições sob as quais pode existir qualquer representação do mundo em geral. (Foucault, 2002a: 333)

A crítica faz sobressair a dimensão metafísica que a filosofia clássica tenta reduzir com a análise da representação; para a crítica, o problema do pensamento clássico reside em seu caráter ilimitado, pois abrange desde as formas mais simples às mais complexas da representação; ademais, é dogmatismo, uma vez que não pode esclarecer a questão de seu direito. Contudo, afirma Foucault, ao interrogar, fora da representação, sua fonte e origem, a crítica abre o pensamento a um outro tipo de metafísica, possibilitando a constituição e o desdobramento das filosofias da Vida, da Vontade, da Palavra, tentações ambíguas, por se pretenderem metafísicas, mas sempre se pautam pela finitude do homem. No pensamento moderno, as reflexões sobre a vida, o trabalho e a linguagem, na medida em que valem como analíticas da finitude, manifestam, para Foucault, o fim da metafísica coetâneo ao aparecimento do homem.

Nesta linha de pensamento, Foucault ressalta, em primeiro plano, a emergência simultânea de um tema transcendental e de novos campos empíricos - ou pelo menos distribuídos e fundados de uma maneira nova. Este acontecimento, que rompe a homogeneidade da episteme clássica, separa as formas puras da análise e as leis da síntese, bem como, no nível da síntese, separa a subjetividade transcendental e o modo de ser dos objetos, fazendo aparecer, correlativamente, duas formas de pensamento. Uma que interroga as condições de uma relação entre as representações do lado daquilo que as torna, em geral, possíveis - descobrindo um campo transcendental onde o sujeito determina, em sua relação com o objeto, todas as condições formais da experiência em geral; aí, a análise do sujeito transcendental vai fornecer o fundamento de uma síntese possível entre as representações. A outra forma de pensamento interroga as condições de uma relação entre as representações, do lado do ser, daquilo que é representado, que se indica a si mesmo como o fundamento da unidade das representações. Trata-se de objetos jamais 
'objetiváveis', representações jamais inteiramente representáveis, visibilidades, ao mesmo tempo, manifestas e invisíveis, realidades que se retiram na medida em que são fundadoras daquilo que se dá nos limites exteriores de nossa experiência: a potência do trabalho, a força da vida, o poder de falar, como objetos de conhecimento.

Buscam-se as condições de possibilidade da experiência, por um lado, no nível empírico - que são as condições de possibilidade do objeto e de sua existência - e, por outro, no nível transcendental - que são as condições de possibilidade do sujeito da experiência. Assim, se justifica a tese foucaultiana de que a positividade das ciências da vida, da linguagem e da economia está em correspondência com a instauração de uma filosofia transcendental que divide o campo do saber em dois níveis diferentes. O campo das ciências empíricas se diferencia, então, do transcendental, porque se aloja do lado do objeto, e, de certo modo, além dele; nele, mostra-se a coerência a priori das multiplicidades empíricas e fundam-se os objetos num ser cuja realidade enigmática constitui, antes de todo conhecimento, a ordem e o elo daquilo a ser conhecido. É o campo dos "transcendentais objetivos" (a Palavra de Deus, a Vontade, a Vida). Diferencia-se, ainda, porque diz respeito ao domínio das verdades a posteriori e aos princípios de sua síntese - e não à síntese $a$ priori de toda experiência possível.

A este fato, Foucault atribui o nascimento das metafísicas, que, apesar de sua cronologia pós-kantiana, aparecem como pré-críticas, pois se desviam do nível da subjetividade, mas só são possíveis na medida em que o domínio da representação se encontra previamente limitado; têm, portanto, o mesmo solo arqueológico da crítica. Ele atribui, também, o aparecimento de um positivismo, a partir da idéia de constituição de uma camada de fenômenos nos limites exteriores de nossa experiência, cuja racionalidade e cujo encadeamento repousam sobre um fundamento objetivo que não é possível esclarecer, a não ser como fenômeno. Porém, tanto num caso como no outro, o pensamento filosófico da universalidade não é do mesmo nível que o campo do saber empírico; a filosofia se constitui seja como uma reflexão pura, como o formalismo de Fichte, seja como uma retomada capaz de desvelar a totalidade do domínio empírico, revelando-se como espírito, ao mesmo tempo, empírico e transcendental, como na fenomenologia hegeliana.

Instaura-se, a partir da crítica - ou, antes, a partir deste deslocamento com relação à representação, do qual o kantismo é a primeira constatação filosófica - uma correlação fundamental: em um pólo, as metafísicas do 
objeto, mais exatamente metafísicas deste fundamento jamais passível de objetivação de onde os objetos vêm a nosso conhecimento superficial; em outro, as filosofias que observam isto mesmo que é dado a um conhecimento positivo. Os dois pontos desta oposição apóiam-se e reforçam-se um ao outro; as metafísicas dos fundamentos ou dos "transcendentais objetivos" vão explorar os conhecimentos positivos. Inversamente, é na divisão entre o fundamento incognoscível e a racionalidade do cognoscível que os positivismos encontrarão sua justificação. O triângulo crítica-positivismo-metafísica do objeto é constitutivo do pensamento europeu, desde o início do século XIX até Bergson. Tal organização da episteme está ligada à emergência destes campos empíricos, que a pura e simples análise interna da representação não pode mais resolver. Ela é correlativa de um certo número de disposições próprias à modernidade. No nível das ciências, as disciplinas analíticas se distinguem das sintéticas, formando, por um lado, um campo de ciências a priori, dedutivas, provenientes da lógica e das matemáticas; por outro, um domínio de ciências a posteriori, empíricas, que só utilizam as formas dedutivas por fragmentos e em regiões estreitamente localizadas.

De acordo com Foucault, surge daí a preocupação epistemológica da modernidade de reencontrar, num outro nível, a unidade perdida com a dissociação da mathesis e da ciência universal da ordem. Surge, também, a reflexão moderna sobre as ciências que classifica domínios do saber a partir da matematização, dos métodos empíricos da indução, do esforço de fundamentação filosófica e de justificação formal da economia, da biologia e da lingüística. Ao mesmo tempo, contudo, afirma-se a impossibilidade destes procedimentos, em nome da especificidade irredutível da vida, do trabalho e da linguagem, bem como do caráter singular das ciências humanas que resistiriam a toda redução metodológica. Há, portanto, na modernidade, uma dupla afirmação: a possibilidade e a impossibilidade de formalizar o empírico e colocar a matematização no centro de todo projeto científico, em conseqüência tanto da divisão que separa as formas puras de análise e as formas sintéticas, quanto da distinção entre a subjetividade transcendental e o modo de ser dos objetos.

Toda a episteme moderna é, assim, marcada pela impossibilidade de conferir um valor transcendental aos conteúdos empíricos, de deslocá-los para o nível de uma subjetividade constituinte, sem dar lugar, ao menos silenciosamente, a uma antropologia. Foucault rejeita o caráter antropológico do pensamento moderno e esforça-se para dele se afastar. Ele o atribui à redução do pensamento operada pela questão kantiana "o que é o homem?", a partir de que 
há a confusão do transcendental e do empírico. Contudo, é difícil explicitar a relação desta tese com o pensamento kantiano e, sobretudo, o papel atribuído a Kant em As Palavras e as Coisas.

Béatrice Han enfatiza a obscuridade da posição de Foucault diante do criticismo. Para ela, Foucault retoma a questão crítica das condições de possibilidade do saber, mas mostra a impossibilidade da resposta kantiana, tentando escapar à configuração antropológica que Kant gerou involuntariamente. Ele é considerado, por Foucault, como o primeiro a se interrogar sobre as condições de possibilidade da representação e de todo conhecimento possível, abrindo o espaço do pensamento moderno, no qual se situa a obra de Foucault, conforme ele mesmo afirma, evocando, em 1966, a injunção repetida de reavivar o corte estabelecido por Kant para tomá-lo em toda a sua extensão.

Entretanto, segundo ela, Foucault nega, por duas vezes, a pertinência da resposta apresentada na Crítica da Razão Pura. Primeiro, ao estabelecer, na introdução não publicada à tradução feita por Foucault, do texto escrito por Kant - Antropologia do Ponto de Vista Pragmático, a gênese do tema transcendental, mostrando, no próprio Kant, duas versões contraditórias: a formulação inicial da Crítica, que distingue, cuidadosamente, o campo empírico de suas condições a priori, e a da Antropologia, onde o tema transcendental sofre uma modificação, simbolizada pela centralização da tripla interrogação crítica da razão ${ }^{76}$ na questão "o que é o homem?", e concretizada, filosoficamente, pela transposição do a priori em originário. Este deslocamento ocasiona duas dificuldades do pensamento moderno que estabelecem a confusão do empírico e do a priori: a busca dos conteúdos empíricos das condições de possibilidade do conhecimento e a busca dos elementos da determinação transcendental na finitude do homem.

A segunda negação de Foucault da solução kantiana diz respeito ao pensamento pós-kantiano, considerado em As Palavras e as Coisas como aprisionado pela analítica da finitude que reduz o campo do saber possível ao homem e seus duplos (o empírico e o transcendental, o cogito e o impensado, o retorno e a origem). Parece, então, para Han, que o kantismo, é, para Foucault, aquele que instaura o espaço discursivo em que se desdobrará a modernidade e, numa ambivalência fundamental, se desdobrará em seu limite intransponível.

Ao fazê-lo, Han ressalta o esforço de Foucault para estabelecer uma nova maneira de relacionar filosofia e história que escape à gênese das ciências hu-

\footnotetext{
${ }^{76}$ As três questões de Kant: a teórica da metafísica - o que posso saber?; a prática da moral - o
} que devo fazer? e a teórico-prática da religião - o que me é permitido esperar?. 
manas e à gênese contemporânea das formas de subjetividade. Neste sentido, Han situa Foucault entre o idealismo excessivo de Kant e dos pós-kantianos e o materialismo reducionista dos marxistas. A crítica do transcendental nos primeiros escritos de Foucault é, para ela, essencial na medida em que denuncia as ilusões antropológicas da modernidade e busca uma resposta válida para a questão das condições de possibilidade, através da renovação do tema transcendental, com o conceito 'um pouco gritante' de a priori histórico, o que confere a seu pensamento uma relação ambígua com a fenomenologia.

Ao contrário do caráter anistórico do a priori e do método transcendental kantiano, o conceito de a priori em Foucault é histórico e seu método arqueológico, para estabelecer uma nova relação da filosofia com a história e denunciar as ilusões antropológicas. $\mathrm{O}$ a priori histórico estaria na linha da busca de uma resposta válida para a questão das condições de possibilidade, que renova o tema transcendental através do conceito de Husserl de a priori histórico, primeiro a formular este conceito como origem. Para Han, Foucault avizinha-se, assim, da fenomenologia, por ele rejeitada ao considerar que a noção de originário e de origem como fundamento, manifesta a confusão do empírico e do transcendental.

Han questiona estas ambivalências através de uma crítica à noção de a priori histórico formulada em As Palavras e as Coisas. Sua análise baseia-se na exigência, à qual ela se prende, de restituir, ao conjunto da obra de Foucault, a coerência de um projeto único - o próprio Foucault o permitiria ao afirmar, na História da Sexualidade 2, ter tratado sempre do mesmo problema -, as relações entre o sujeito, a verdade e a constituição da experiência. Ela projeta estas questões arqueológicas, seus conceitos e objetivos, para período posterior - o da genealogia - e encerra a análise do conceito de a priori histórico, em Foucault, considerando o abandono posterior deste conceito, por ele, uma evidência da impossibilidade de solucionar as dificuldades aí existentes. Em L'Ontologie Manquée de Michel Foucault (Han, 1998), diversos argumentos são utilizados para levar as análises de Foucault a posições de contradição, retirando-lhes o poder explicativo. Ela atém-se, assim, a um questionamento fundado na busca da unidade do projeto ao longo de toda a obra. Han aponta o fracasso do método arqueológico, sem conduzir, como eles, a análise à solução foucaultiana da ultrapassagem do estruturalismo e da hermenêutica.

Ao desconsiderar o caráter não sistemático e, sobretudo, as descontinuidades das pesquisas de Foucault - que ele fez questão de afirmar em diversas ocasiões -, as análises de Han não contribuem para as questões suscitadas 
pelo tema da representação e constituição do objeto na modernidade, tema abordado em As Palavras e as Coisas, de acordo com a especificidade desta pesquisa. De um modo geral, o problema da análise de Han é não admitir, em filosofia, a perspectiva da trajetória que é fundamental para compreender a contribuição de As Palauras e as Coisas para o pensamento filosófico.

Sem dúvida, a melhor forma de elucidar o problema da interpretação de Foucault sobre o papel de Kant é formulada por Roberto Machado a partir da dupla inspiração de Foucault no pensamento da epistemologia francesa, em particular de Canguilhem e no de Nietzsche. Em Foucault, a Filosofia e a Literatura, Machado (2000b) não só retoma a tese, desenvolvida em Ciência e Saber (1981), da inspiração metodológica da arqueologia na epistemologia, que confere precisão às análises do saber, como evidencia vários aspectos da inspiração na crítica nietzschiana, como o estilo não dialético e não fenomenológico de pensamento; o esforço de Foucault, nos anos 60, para escapar de uma filosofia do sujeito ou da consciência; a literatura como alternativa ao homem considerado como a priori histórico dos saberes da modernidade; a contestação do humanismo das ciências do homem e das filosofias modernas; a afirmação de que apenas as sociedades modernas pensaram, especificamente, o homem, invenção recente, cujo fim está próximo.

Machado desenvolve seu argumento explicitando, primeiramente, a relação estabelecida por Foucault entre o nascimento das ciências empíricas biologia, economia, filologia - e a problemática do homem na modernidade: os estudos da vida, do trabalho e da linguagem pelas ciências empíricas tornam o homem, pela primeira vez, objeto de saber. Estudar os objetos empíricos é estudar o homem porque ele é meio de produção, se situa entre os animais e possui linguagem. Mas estes objetos também o determinam, pois são o único meio de conhecer o homem empiricamente. A dependência do homem com relação aos objetos empíricos significa que, através deles, ele se descobre como ser finito, mas não negativamente, subordinando-se ao infinito, como na idade da representação, pois a modernidade tem uma dimensão antropológica manifesta no nível dos saberes empíricos.

O nascimento das ciências empíricas, que cria o homem como um objeto empírico, um ser finito, histórico, é coetâneo do nascimento de um novo tipo de filosofia em que o homem aparece como fundamento. Isto seria uma novidade da episteme moderna. Para Machado, apesar de tudo, a posição de Foucault é clara. O limiar da modernidade é a busca kantiana das condições 
de possibilidade do conhecimento dos objetos, necessariamente submetidos ao sujeito transcendental, através de uma reflexão em que o lugar do conhecimento é exterior ao quadro das representações.

Para Foucault, o essencial é o aparecimento de um sujeito que só dispõe de um conhecimento a priori, na medida em que não tem intuição intelectual e é finito, como em Heidegger. Agora, para conhecer, é necessário, além da representação - intelectual, conceitual -, o fenômeno, a diversidade sensível, apresentada ao sujeito como uma intuição sensível. Diferentemente do conhecimento clássico, que consistia na análise das representações, desdobrando-se infinitamente, o conhecimento moderno é sintético e limitado: síntese de uma representação intelectual e uma representação sensível espaço-temporal; os próprios limites do conhecimento fundam a possibilidade do saber porque o homem só pode conhecer o que é sensível. E é a filosofia considerada como crítica transcendental que, através de uma análise do sujeito transcendental, extrai o fundamento desta síntese possível.

Com Kant, tanto a filosofia quanto a ciência escapam da representação, situando-se em níveis diferentes: o da ciência, que diz respeito ao objeto empírico, e o da filosofia, que diz respeito ao sujeito, ao fundamento transcendental do conhecimento; a filosofia é uma reflexão sobre as condições de possibilidade de todo conhecimento e uma analítica de tudo o que pode se dar, em geral, à experiência do homem. Eis a invenção do homem como sujeito e objeto do conhecimento. Como objeto, como fato, nas sínteses empíricas; como sujeito, como condição, na analítica transcendental.

Machado esclarece a posição de Foucault: Kant significa o limiar da nossa modernidade. Ao contrário de Han, que vê uma ambigüidade, dois pontos de vista contraditórios, ele interpreta esta posição de Foucault como tendo duas perspectivas diferentes, mas não contraditórias. Por um lado, a perspectiva de uma análise dos limites da representação, no nível das ciências e no da filosofia: Kant é considerado como tendo introduzido, ou, mais precisamente, sancionado, a ruptura que funda nossa modernidade, por ter sido o primeiro a interrogar, criticamente, a representação clássica a partir de seus limites e do a priori que a torna possível. Neste sentido, Foucault ressalta a distinção entre os níveis empírico e transcendental operada na crítica, argumentando que, para Kant, o sujeito que não é empírico jamais é dado à experiência.

Por outro lado, na perspectiva das filosofias que se constituem em decorrência da ruptura que a crítica estabelece, Kant é, também, para Foucault, aquele que formulou a questão antropológica “o que é o homem?". E, a este 
respeito, dá como exemplo a Lógica, que retoma as três questões contidas na crítica e as faz convergir para uma quarta - "o que é o homem?" -, objeto da antropologia. Para Machado, Foucault não faz esta afirmação como uma crítica a Kant, porque, se, para ele, esta questão opera a confusão do empírico e do transcendental, esta confusão, embora diga respeito à antropologia, é posterior a Kant.

Machado explica que, ao assinalar que a antropologia teve um papel constituinte no pensamento moderno, Foucault afirma que Kant viu bem que as sínteses empíricas devem ser fundadas na finitude do homem, como mostra a questão "o que é o homem?", mas, Foucault afirma logo a seguir isto é relevante - que esta questão percorre o pensamento desde o início do século XIX, operando, furtiva e previamente, a confusão entre o empírico e o transcendental. De acordo com Machado (2000b), ao contrário do ressaltado por Han, não há contradição desta afirmação com a feita, no mesmo item do livro, de que a Antropologia, talvez, constitua a disposição fundamental do pensamento filosófico, desde Kant até nós, pois a antropologia não implica, necessariamente, a confusão que Foucault pretende denunciar, embora possa se constituir como um perigo a este respeito.

O fato de considerar Kant privilegiando os projetos diferentes de constituição de uma crítica e de uma antropologia, afirma Machado, prejudica a elucidação da posição de Foucault. Porém, a principal dificuldade de se apreender sua posição com clareza está não aí, mas na ambivalência de sentido do termo antropologia, que Foucault, praticamente, não explicita. Para elucidar esta noção, Machado recorre à entrevista "Philosophie et psychologie" (Foucault, 1994a), em que Foucault afirma que a finitude, ao ser pensada independentemente do infinito, de Deus, traz a possibilidade ou o perigo de uma antropologia, no sentido de consistir numa estrutura filosófica que aloja os problemas da filosofia no domínio da finitude humana. Ao retomar esta idéia, Machado considera a definição de As Palavras e as Coisas ainda mais elucidativa da afirmação da filosofia moderna como confusão do empírico e do transcendental que a transforma em pensamento antropológico, em analítica do homem ou da finitude, cujos limites de direito são as formas concretas da existência dadas no saber empírico.

O principal sentido de antropologia é de confusão do empírico e do transcendental, sentido que Foucault considera como conseqüência perigosa do seu primeiro sentido estabelecido por Kant. Assim, Foucault é conduzido à conclusão de que, embora Kant mantenha a distinção do empírico e do 
transcendental, é origem da confusão posterior que torna o conhecimento empírico sobre o homem um campo filosófico possível para a descoberta do fundamento e dos limites do conhecimento.

Machado aponta a presença desta concepção de antropologia em dois escritos de Foucault, anteriores às Palavras e as Coisas. Primeiramente, referindo-se a Bataille, depois de afirmar que Kant abriu a possibilidade de um pensamento da finitude e do ser, como o de Nietzsche, Foucault considera que Kant a encerrou na questão antropológica, à qual acabou por referir a questão crítica, assimilando-a aos pós-kantianos. Em seguida, no texto já referido por Han, da introdução à Antropologia, em que Foucault se mostra mais aberto ao pensamento kantiano. Ali, embora isto também não fique muito claro, há ambigüidade, ou tensão, como diz Machado, entre os níveis empírico e transcendental, nas antropologias científicas e nas antropologias filosóficas pós-kantianas, mas, na concepção de Kant, a antropologia marca a distinção entre os dois níveis.

Neste sentido é que Foucault afirma que a antropologia de Kant imita a crítica, externa e empiricamente, constituindo-se como uma doutrina sistemática do conhecimento empírico do homem, que não pode fundar-se sobre si própria e tem necessidade de referir-se à Crítica, a ela se subordinando. De acordo com Machado, a posição de Foucault é clara: querer realizar um conhecimento positivo como pensamento crítico é esquecer a lição de Kant, que, apesar de trazer o perigo da confusão, permanece subordinando a antropologia à crítica. Para ele, o motivo desta aparente contradição é o desejo de Foucault de ressaltar que a continuidade entre os dois momentos não é total, no sentido em que Kant, ao criticar a representação a partir do transcendental, abre a perigosa possibilidade ao antropologismo da filosofia moderna, mas não se identifica ou se confunde com ele. Portanto, o que Foucault critica são as antropologias filosóficas que dão acesso natural ao fundamental. A expressão analítica da finitude designa, justamente, uma forma de pensamento em que o ser do homem poderá fundar todas as formas que lhe indicam que ele não é infinito.

A crítica foucaultiana à filosofia moderna dirige-se à sua relação com o aprofundamento da finitude, que se anunciava no empírico a partir do exterior como finitude natural, histórica, objetiva, dominada pelas determinações da vida, do trabalho e da linguagem, de onde não está eliminada a idéia da superação no futuro da finitude; finitude, que, na filosofia, é radical, fundamental, porque atinge a própria consciência do homem e assinala, ao conhecimento, 
suas formas limitadas. Além de o homem ser determinado como finito pelos saberes empíricos, é o homem como ser finito que confere a toda determinação a possibilidade de aparecer em sua verdade fundamental.

Foucault afirma que o limiar da modernidade foi atingido quando a finitude foi pensada a partir de uma referência interminável a si própria, quando o homem, como ser finito, toma o lugar de Deus e a finitude deixa de ser definida a partir da natureza divina do infinito para ser pensada a partir de si mesma. A importância de Kant nesta transformação é ter sido o primeiro a afirmar que o infinito não é mais dado, só existe a finitude, e é neste sentido que a crítica kantiana traz a possibilidade ou o perigo de uma antropologia, do sono antropológico do qual é preciso acordar.

Ao contrário do fracasso da arqueologia proposto por Han, somos conduzidos à afirmação do caráter radical do pensamento de Foucault que busca, fundamentado na história da representação e da constituição do objeto, para a questão kantiana “o que é o homem?", a resposta da morte do homem. E esta resposta Nietzsche já havia encontrado, antes mesmo de termos nascido:

Esta disposição foi por longo tempo constringente; e, no fim do século XIX, Nietzsche a fez cintilar uma última vez, incendiando-a. Retomou o fim dos tempos para dele fazer a morte de Deus e a errância do último homem; retomou a finitude antropológica, mas para fazer fulgir o arremesso prodigioso do super-homem. (Foucault, 2002a: 361) 


\section{1 \\ Ordem Biológica, Poder Disciplinar e Normalização}

No nível genealógico, o objetivo de Foucault não é mais analisar as compatibilidades e incompatibilidades entre saberes a partir da configuração de suas positividades. A vida e as ciências da vida são analisadas do ponto de vista político, das estratégias do poder. É essa análise dos saberes, que pretende explicar sua existência e suas transformações, situando-os como peças de relações de poder ou incluindo-os em um dispositivo político, que Foucault chamará, baseado em Nietzsche, de genealogia. Neste nível, as análises das relações de forças permitem ver que poder disciplinar e biopoder funcionam, por meio de um crescente ordenamento, em todas as esferas sociais, sob o pretexto de desenvolver o bem-estar dos indivíduos e das populações.

Ao tratar a questão da rede de relações de poder, Foucault substitui a perspectiva tradicional da filosofia política por uma questão que considera mais elementar e mais concreta: as regras de direito das quais as relações de poder lançam mão para produzir discursos de verdade eficazes, tanto no nível do discurso, do saber, como no nível das práticas institucionalizadas. As análises genealógicas mostram a relação entre os saberes e as estratégias dos mecanismos econômicos e políticos de nossa sociedade, através do estabelecimento da especificidade e do caráter concreto das relações de poder e saber. Para tanto, obedecem a certas precauções metodológicas: em vez de tomar o poder no sentido de sua caracterização nos aparelhos de Estado e nas ideologias que o acompanham, a história genealógica dirige-se para a dominação, os operadores materiais, as formas de sujeição, os usos e as conexões da sujeição pelos sistemas locais e os dispositivos estratégicos. 
Contra a tradição que estuda o saber como lugar da verdade e da liberdade, e o poder como repressão, interdição e negatividade, Foucault afirma a produção de verdade como correlata das múltiplas coerções e dos efeitos regulamentados do poder. Para ele, as relações de poder são muito mais complexas, não podem se limitar à sua função negativa ou repressiva, pois possuem uma eficácia estratégica, produtiva, que precisa ser estudada. Trata-se da gestão da vida para a qual produz uma série de saberes específicos e de tecnologias de controle e de ordenação, cuja finalidade é a majoração da vida. Aqui é importante lembrar que, ao tratar da questão do poder, Foucault analisa as múltiplas relações de forças que atravessam nossa sociedade. Ele interroga, na genealogia, não o que é o poder, mas como se exerce. Para ele, as generalizações marxistas, que analisam a dominação da classe burguesa, não dão conta desta questão; elas não conseguem demonstrar de que maneira e por que as decisões foram tomadas, como puderam ser aceitas por todos e de que maneira ferem uma determinada categoria de indivíduos. $\mathrm{O}$ poder não pode ser confundido com o Estado, que não é o seu único detentor; toda a sociedade é vazada por micropoderes locais, específicos, circunscritos a uma pequena área de ação. Pois há uma multiplicidade de formas de exercício de poder diferentes do Estado, a ele articuladas de maneiras indispensáveis à sua ação. Não se trata, contudo, de minimizar o papel do Estado. Seu interesse é ver como os poderes específicos, os micropoderes, que possuem uma tecnologia e história próprias, a ele se relacionam. Foucault rejeita o binômio simplificador dominantes/dominados, dirigindo sua pesquisa para os múltiplos mecanismos locais - circunscritos a uma pequena área de ação - do poder que possuem uma eficácia produtiva para fazer do indivíduo e da população entidades saudáveis e normais, através das tecnologias de normalização e de sujeição à força da disciplina.

Foucault define as disciplinas, de uma maneira global, como tecnologias para assegurar a ordenação das multiplicidades humanas que tentam traçar, a respeito das multiplicidades, uma tática de poder tanto para tornar o exercício do poder o menos custoso possível (economicamente, pela pouca despesa que acarreta; politicamente, por sua relativa invisibilidade e pela baixa resistência que pode suscitar) quanto para fazer com que os efeitos deste poder social correspondam ao máximo de intensidade possível, bem como para fazer crescer a docilidade e a utilidade de todos os elementos do sistema. Em Vigiar e Punir, vimos que, durante a época clássica, o corpo é valorizado como objeto e como alvo de poder, entrando em dois registros diferentes, seja como submissão e utilização de submissão, seja como funcionamento e explicação: 
O grande livro do Homem-máquina foi escrito simultaneamente em dois registros: no anátomo-metafísica, cujas primeiras páginas haviam sido escritas por Descartes e que os médicos, os filósofos continuaram; o outro, técnico-político, constituído por todo um conjunto de regulamentos militares, escolares, hospitalares e por processos empíricos e refletidos para controlar ou corrigir as operações do corpo. (Foucault, 1987: 117)

A novidade da nova forma de se dirigir ao corpo, à qual Foucault se refere, diz respeito, em primeiro lugar, ao modo como o controle se faz, através de um poder analítico infinitesimal em termos de movimentos, gestos, velocidade; em segundo lugar, refere-se ao controle que se dirige às forças e não ao signo. Diz respeito, ainda, à modalidade do exercício de poder, uma forma de controle que implica uma coerção ininterrupta, constante, do processo da atividade e não de seus resultados, exercendo-se segundo uma codificação que esquadrinha o tempo, o espaço, os movimentos, impondo uma relação de docilidade e utilidade. É assim que Foucault define as disciplinas, que se tornaram, durante o século XVII e XVIII, as formas gerais da dominação.

A disciplina majora as forças do corpo em termos econômicos e as diminui em termos políticos. O corpo humano passa a ser fustigado, desarticulado, recomposto, através de uma anatomopolítica do detalhe, que desenvolve técnicas para viabilizá-la - como a repartição dos indivíduos no espaço - trabalhando de uma maneira sutil e fina. Funda-se no princípio da localização elementar ou do esquadrinhamento.

O esquadrinhamento permite que cada indivíduo tenha seu lugar, e, inversamente, que em cada lugar esteja um indivíduo, evitando as distribuições por grupos, decompondo as coletividades, analisando a pluralidade confusa. $\mathrm{O}$ espaço disciplinar tende a se dividir em infinitas parcelas, tantas quantas forem necessárias para repartir todos os corpos e todos os elementos, organizando um espaço analítico (na sua arquitetura). $\mathrm{O}$ exemplo dado por Foucault são as celas dos conventos.

A anatomopolítica do detalhe funda-se, também, na regra das localizações funcionais que penetram nas instituições disciplinares como os hospitais. A vigilância médica das doenças e dos contágios é correlata de uma série de outros controles: militar sobre os desertores - como no hospital militar. Pouco a pouco, afirma Foucault, um espaço administrativo e político se articula com um espaço terapêutico, que tende a individualizar os corpos, as rações dos animais, os desaparecimentos, as curas, as mortes, as simulações etc., fazendo nascer um espaço medicamente útil. 
Relevante, para este estudo, é o fato de que, na anatomopolítica, os elementos são intermitentes, já que cada um deles se define pelo lugar que ocupa numa série, assim como pela distância que o separa dos outros. A unidade se deve à classe, à categoria, ao lugar ocupado numa classificação, o ponto onde uma linha e uma coluna se cruzam, o intervalo numa série de intervalos que podem ser percorridos um a um. Assim, a disciplina individualiza os corpos através de uma localização que os distribui e os faz circular numa rede de relações. O exemplo dado por Foucault, neste caso, é o da classe nos colégios dos jesuítas. A classe, no século XVIII, começa a definir a grande forma de repartição dos indivíduos na ordem escolar, onde a sala de aula formaria um grande quadro único, com entradas múltiplas, sob o olhar cuidadosamente classificador do professor.

As disciplinas organizam as celas, os lugares e as classes fabricando espaços complexos, que são, ao mesmo tempo, arquitetônicos, funcionais e hierárquicos, cujo objetivo é assegurar a fixação e permitir a circulação, recortar os segmentos individuais e estabelecer ligações operatórias, garantir a obediência dos indivíduos e uma melhor economia do tempo e do espaço. A disciplina ajuda a fazer funcionarem as relações de poder da maneira mais discreta e econômica possível, através de poderes anônimos, exercidos pelos regimentos, pela vigilância hierárquica, pelo registro contínuo, pelo exame e pela classificação. Seu principal objetivo é assegurar a regulação do corpo social inteiro. Ela corresponde ao projeto de criação de uma sociedade sadia e ao estabelecimento de uma economia social, ambos, como sempre, vinculados ao projeto de transformação do desviante - mendigo, louco.

Ao analisar a disciplina, Foucault afirma, em Vigiar e Punir, que sua primeira grande operação é constituir "quadros vivos" que transformam as multidões confusas, inúteis ou perigosas, em multiplicidades ordenadas. "A constituição de 'quadros' foi um dos grandes problemas da tecnologia científica, política e econômica do século XVIII; arrumar jardins de plantas e de animais, e construir ao mesmo tempo classificações racionais dos seres vivos" (Foucault, 1987: 127).

O quadro será, no século XVIII, ao mesmo tempo, uma técnica de poder e um procedimento de saber, que organiza o múltiplo, impondo uma ordem que instrumentaliza o controle da multiplicidade. Apesar de reconhecer funções diferenciadas nos diferentes tipos de registro, Foucault reúne o estrategista de guerra, o naturalista, o médico e o economista, a partir da idéia da utilização de tecnologias como a tática, o ordenamento espacial dos homens, a 
taxonomia, o espaço disciplinar dos seres naturais, o quadro econômico, o movimento regulado das riquezas.

Foucault se detém na especificação destas funções no plano da economia. Aí, o quadro permite medir diferentes quantidades e analisar os movimentos. Sob a forma da taxonomia, o quadro tem por função caracterizar e reduzir as singularidades individuais e constituir classes, excluindo as considerações de número. Sob a forma da repartição disciplinar, o quadro tem por função tratar a multiplicidade em si mesma, distribuíla e retirar-lhe efeitos possíveis. Enquanto a taxonomia natural se situa no eixo que vai do caráter à categoria, a tática disciplinar se situa no eixo que liga o singular e o múltiplo, permitindo a caracterização do indivíduo como indivíduo, assim como a ordenação de uma multiplicidade dada. O quadro é a condição primeira para o controle e o uso de um conjunto de elementos distintos.

A disciplina atinge o corpo do indivíduo através do controle não só do espaço, ordenador e classificatório, mas também do tempo, igualmente classificatório. Mais uma vez, Foucault analisa a organização institucional para demonstrar sua idéia. Sua intenção não é, contudo, fazer a história das diferentes instituições disciplinares para mostrar o que cada uma pode ter de particular, como ele mesmo ressalta; sua intenção é assinalar, por meio de exemplos, algumas das técnicas disciplinares essenciais. A exatidão, a regularidade e a aplicação são as características fundamentais do tempo, que ajusta os corpos aos imperativos temporais, na forma de um programa que controla seu desenvolvimento e cada uma de suas fases nas quais se divide.

Dentre outros, o exemplo das grandes manufaturas é esclarecedor por causa do rigor do tempo industrial que regulamenta sua divisão em termos de atividade: "Todas as pessoas (...), chegando a seu ofício de manhã, antes de trabalhar começarão lavando as mãos, oferecerão seu trabalho a Deus, farão o sinal da cruz e começarão a trabalhar" (Foucault, 1987: 128).

Foucault mostra o esquadrinhamento do tempo na instituição: ele assegura a qualidade de seu emprego através do controle ininterrupto, da pressão das vigilâncias, da anulação de tudo o que pode perturbar e distrair, com o objetivo de constituir um tempo útil, uma vez que o tempo medido e pago deve ser um tempo bom, bem calculado, puro, ao longo do qual o corpo se exercita, executando tarefas. $\mathrm{O}$ tempo é decomposto em seus elementos; a posição do corpo, dos membros, das articulações é definida; para cada movimento, atribui-se uma direção, uma amplitude, uma duração; sua ordem de sucessão é prescrita. Deste modo, o tempo penetra no corpo e, com ele, todos 
os controles minuciosos do poder, através de uma decomposição do gesto global em séries paralelas dos elementos do corpo em questão - mão direita ou esquerda, dedos, joelhos etc. -, dos elementos dos objetos manipulados, relacionando-os com um certo número de gestos simples.

O importante nisto tudo é que as técnicas de esquadrinhamento do tempo são técnicas de sujeição dos corpos que buscam a perfeição disciplinar, através da produção de um novo objeto, que é o corpo natural, portador de forças e fonte de uma duração; corpo suscetível de operações especificadas que tem sua ordem, seu tempo, suas condições internas, seus elementos constitutivos, alvo de novos mecanismos de poder e que se oferece a novas formas de saber.

Assim, Foucault analisa de que modo os procedimentos da repartição disciplinar correspondem a técnicas de classificação e de ordenação em quadros, como também de que modo introduzem o problema específico dos indivíduos e da multiplicidade. Da mesma forma, os controles disciplinares da atividade correspondem a todas as pesquisas teóricas e práticas sobre a maquinaria natural do corpo. Ao mesmo tempo, descobrem-se processos específicos ao corpo, comportamentos e exigências orgânicas que vão substituir a simples física do movimento. $\mathrm{O}$ corpo aparece como tendo condições de funcionamento próprias a um organismo que fazem com que o poder disciplinar se dirija a uma individualidade analítica, celular, natural e orgânica. A partir dos corpos que controla, a disciplina fabrica individualidades.

Por meio das disciplinas, aparece o poder da norma. Na sociedade moderna, o normal se estabelece como princípio de coerção no ensino, com a instauração de uma educação estandardizada e com o estabelecimento das escolas normais. Ele se estabelece no esforço de organizar um corpo médico e um enquadramento hospitalar da nação suscetíveis de fazer funcionarem normas gerais de saúde; se estabelece, também, na regularização dos procedimentos e dos produtos industriais. Do mesmo modo que a vigilância, a normalização se torna um dos grandes instrumentos de poder no final da época clássica. Ela substitui ou acrescenta graus de normalidade, que são signos de pertencimento a um corpo social homogêneo, mas que têm um papel de classificação e de distribuição das classes.

Num certo sentido, o poder de normalização constrange com o objetivo de homogeneizar as multiplicidades, ao mesmo tempo que individualiza, ao permitir medir as distâncias, determinar os níveis, fixar as especialidades e tornar úteis as diferenças. $\mathrm{O}$ exame combina as técnicas da hierarquia, que vigia, e as da sanção, que normaliza. $O$ texto sobre o exame, em Vigiar e Punir, 
é muito importante para o conjunto das pesquisas de Foucault. É nele que Foucault explicita muito claramente a articulação do nível do saber com o nível do poder. Uma vez que o exame se constitui por uma técnica tanto de poder quanto de saber, esta noção orienta a hipótese de trabalho de Foucault, segundo a qual o saber não pode ser analisado a partir da chave de explicação da ideologia, nem o poder, pela da repressão.

Se o poder é tomado como repressão, ele é negativo e tem, como correlato, um saber ideológico também negativo, porque mascara o poder. Mas, para Foucault, sabemos, o poder é positivo, no sentido da produtividade; ele produz um certo tipo de indivíduo e de população - normal - necessários à existência e à manutenção da sociedade capitalista. Para esta produção, são necessários saberes. A normalização é uma positividade. O exame é um olhar que normaliza, uma vigilância que permite qualificar, classificar e punir os indivíduos. Ele impõe o princípio da visibilidade, através da qual os indivíduos são diferenciados e sancionados. Por esta razão, o exame é o dispositivo da disciplina mais submetido a rituais - na escola, no hospital etc.

O exame reúne a cerimônia do poder e a forma da experiência, o desdobramento da força e o estabelecimento da verdade. Ele manifesta a sujeição daqueles que são percebidos como objetos e, ao mesmo tempo, a objetivação daqueles que são assujeitados, ao inverter a economia da visibilidade no exercício do poder. Tradicionalmente, o poder é o centro da visibilidade; porém o poder disciplinar se exerce de forma invisível, impondo àqueles que submete um princípio de visibilidade obrigatória.

O modelo arquitetural de Bentham (1977), exposto em Le Panoptique é apresentado como o diagrama de um mecanismo de poder reduzido à sua forma ideal (Foucault, 1987). Seu funcionamento, uma vez abstraído de todo obstáculo, resistência ou choque, pode ser representado como um puro sistema arquitetônico e ótico; consiste numa figura de tecnologia política. Apresenta os princípios de uma forma de poder, cuja base fundamental é o princípio do "panoptismo", princípio da vigilância exercida pela total visibilidade de quem deve ser vigiado, e da fórmula "ver sem ser visto". Ressalte-se, aqui, o desconforto, o mal-estar que o exercício destes princípios gera, sobretudo por consistir num dispositivo que age pelo efeito de uma visibilidade geral e coage pelo jogo do olhar vigilante.

A outra função importante do exame é a escritura disciplinar, pois cria arquivos, através do registro, da organização em série, da organização de campos comparativos que permitem classificar, formar categorias, estabelecer 
médias, fixar normas, viabilizando a função que estabelece hierarquias como instrumento do poder disciplinar.

Em História da Sexualidade 1, Foucault mostra que, a partir do século XVIII, quando aparece o domínio da biologia como ciência da vida, cada vez mais, os mecanismos do poder se dirigem ao corpo, à vida, ao que faz proliferar, ao que reforça a espécie, à vitalidade do corpo social. Os novos procedimentos de poder, elaborados durante a época clássica e postos em ação no século XIX, atuam sobre a vida dos indivíduos e das populações através da norma, do saber, da disciplina e das regulamentações. Como vimos, o poder disciplinar atinge o corpo, com táticas específicas, ordenando as diferenças humanas.

Na época clássica, o poder marca seu direito sobre a vida pela morte que pode exigir, ou melhor, pelo direito de causar a morte ou de deixar viver. Mas ele era, sobretudo, o direito de apreensão das coisas, de confisco do tempo, dos corpos e da vida; culminava com o privilégio de se apoderar da vida para suprimi-la. Mais tarde, este confisco tende a ser uma entre outras funções do poder, cuja função principal passa a ser produzir forças, fazê-las crescer e ordená-las mais do que barrá-las ou destruí-las. A partir da época clássica, o confisco passa a ser apenas uma peça do poder, entre outras, com funções de incitação, reforço, controle, vigilância, majoração e organização das forças; o direito de morte tenderá a se apoiar nas exigências da gestão e ordenação da vida. O poder de morte apresenta-se, então, como o complemento de um poder que se exerce, de forma positiva, sobre a vida. Mas, à medida que o poder assume a função de gestão da vida, torna-se cada vez mais difícil a pena de morte. Estes processos são assumidos mediante uma série de intervenções e controles reguladores da biopolítica da população. O seu papel mais importante é o de garantir, sustentar, reforçar, multiplicar a vida e colocá-la em ordem. No decorrer da época clássica, há, afirma Foucault (2001: 131),

Desenvolvimento rápido, no decorrer da época clássica, das disciplinas diversas - escolas, colégios, casernas, ateliês; aparecimento, também, no terreno das práticas políticas e observações econômicas, dos problemas de natalidade, longevidade, saúde pública, habitação e migração; explosão, portanto, de técnicas diversas e numerosas para obterem a sujeição dos corpos e o controle das populações. Abre-se, assim, a era de um biopoder. As duas direções em que se desenvolve ainda aparecem nitidamente separadas, no século XVIII. Do lado da disciplina as 
instituições como o Exército ou a escola; as reflexões sobre a tática, a aprendizagem, a educação e sobre a ordem da sociedade; (...). Do lado das regulações de população a demografia, a estimativa da relação entre recursos e habitantes, a tabulação das riquezas e de sua circulação, das vidas com sua duração provável.

A partir do século XIX, o poder transforma-se em agenciamentos concretos - o dispositivo da sexualidade será um deles, por exemplo - que constituirão a grande tecnologia do poder no século XX, capaz de majorar as forças, a vida em geral, através da inserção controlada dos corpos no aparelho de produção e por meio de um ajustamento dos fenômenos de população aos processos econômicos. Os rudimentos da anátomo e biopolítica - inventados no século XVIII -, utilizados por instituições bem diferentes (a família, o exército, a escola, a polícia, a medicina individual ou a administração das coletividades), agiram no nível dos processos econômicos e das forças da vida, através de métodos de poder capazes de majorar a vida em geral e de técnicas presentes em todos os níveis do corpo social, utilizadas por diversas instituições.

No século XVIII, a possibilidade de encarregar-se da vida e de seus mecanismos, no domínio dos cálculos e da transformação da vida humana, é o que Foucault (2001: 134) chama de "limiar de modernidade biológica" de uma sociedade. "O homem, durante milênios", ele afirma, "permaneceu o que era para Aristóteles: um animal vivo e, além disso, capaz de existência política; o homem moderno é um animal, em cuja política, sua vida de ser vivo está em questão". O novo modo de relação da vida com a história faz com que seja colocada a questão do homem, em sua especificidade de ser vivo e em relação aos outros seres vivos. Foucault ressalta a importância da proliferação das tecnologias políticas, investindo sobre o corpo, a saúde, as maneiras de se alimentar e de morar, as condições de vida, todo o espaço da existência.

O exemplo desta tecnologia política da vida é o sexo como disputa política que se encontra na articulação entre as disciplinas do corpo e a regulação das populações. Desta forma, o sexo é alvo, por um lado, de vigilâncias infinitesimais, de controles constantes, de ordenações de extrema meticulosidade, de exames médicos ou psicológicos infinitos, correspondentes ao poder sobre o corpo. Por outro lado, o sexo é alvo de medidas maciças, de estimativas estatísticas, de intervenções que visam ao corpo social tomado globalmente. 
Com a biopolítica, leva-se em conta a vida, os processos biológicos do homem como espécie e tenta-se assegurar sobre os mesmos, não uma disciplina, mas uma regularização. A partir do século XVIII, os mecanismos de poder, que tinham como matriz operacional o modelo da soberania, tornam-se inoperantes diante da necessidade de governar o corpo político e econômico de uma sociedade em vias de explosão demográfica e de industrialização. ${ }^{77}$

As sociedades de normalização não podem ser compreendidas como disciplinares. Nelas cruzam-se a norma de disciplina e a norma de população. A norma recobre a superfície que vai do orgânico (corpo) ao biológico (espécie) e recupera, em seus procedimentos, mecanismos mais gerais de intervenção e de poder, como aqueles das medidas de administração empreendidas pelo Estado. Em Segurança, Território de População (2008), Foucault mostra a passagem da disciplina a uma outra economia do poder, a segurança, com o surgimento da noção de população, considerando a disciplina e os mecanismos de segurança como diferentes faces da normalização. É preciso diferenciar normalização e normatização. Ao se perguntar o que é normalização, Foucault salienta que Kelsen ${ }^{78}$ já queria demonstrar que todo sistema de leis reporta a um sistema de normas, indicando, na lei, algo que poderia se chamar de normatização. Esta normatização não pode ser confundida com os procedimentos técnicos de normalização estudados por Foucault.

A disciplina normaliza no sentido de definir um modelo ótimo - a norma - para conformar pessoas, gestos e atos a este modelo. O fundamental neste caso é a anterioridade da norma em relação ao que será definido, posteriormen-

77 A este respeito, Marcio Alves da Fonseca (2000: 226) observa que, para a garantia do detalhe das distribuições espaciais e das atividades, teria havido uma primeira acomodação - a acomodação dos mecanismos de poder individual, definindo-se o domínio denominado disciplina. E, para recuperar os fenômenos globais de regulação dos grupos, teria havido uma segunda acomodação - a dos mecanismos de poder sobre os fenômenos de população. Definem-se, assim, duas séries: "a série corpo (organismo - disciplina) - instituições" e a "série população (processos biológicos - mecanismos de segurança) - Estado”. O elemento que as articula é a norma.

${ }^{78}$ De acordo com nota de Segurança, Território e População, Hans Kelsen (1881-1973) foi professor de direito público e filosofia em Viena e em Copenhague. Exonerado pelos nazistas, prosseguiu carreira em Genebra e Berkeley. Fundador da Escola de Viena, que radicalizava a doutrina do positivismo jurídico, defendeu uma concepção normativista do direito, segundo a qual o direito constitui um sistema hierarquizado e dinâmico de normas, articuladas umas às outras por uma relação de imputação (distinta da relação de causalidade, em que se baseia o raciocínio científico), isto é, a relação entre certo comportamento como condição e uma sanção como conseqüência. Para não levar a uma regressão ao infinito (fazendo todo poder jurídico decorrer necessariamente de autorizações jurídicas superiores), esse sistema extrai sua validade de uma norma fundamental, que não é posta como as outras normas, mas pressuposta e, por isso, suprapositiva (Foucault, 2008). 
te, como normal ou anormal. Trata-se, então, de um processo de "normação", não de normalização. Nos mecanismos de segurança, o normal antecede a norma do qual é deduzida. Foucault exemplifica o mecanismo de normalização dos dispositivos de segurança com os procedimentos de "variolização" e de vacinação no século XVIII, esclarece Fonseca. Em tais dispositivos, são combatidas as anormalidades mais desfavoráveis, mais desviantes em relação ao que se poderia definir como uma curva normal geral. Trata-se de apreender o normal e o anormal, distribuindo as diferentes curvas de normalidade, conduzindo as mais desfavoráveis para um estado mais favorável. Estas distribuições servirão de norma que será um jogo interior das normalidades diferenciais.

O biopoder caracteriza-se, portanto, por uma importância crescente da norma que distribui os vivos num campo de valor e utilidade. Este poder qualifica, mede, avalia, hierarquiza, operando distribuições em torno da norma. A lei funciona mais como norma com funções reguladoras. Uma sociedade normalizadora é o efeito histórico de uma tecnologia de poder centrada na vida como espécie.

\section{Foucault, Canguilhem e A QUeStÃo dA nORMalizaÇÃo}

A delimitação dos objetos tratados por Foucault - como a loucura, a doença, a criminalidade, as instituições médicas, judiciais e pedagógicas, o poder disciplinar e normalizador - pode ser compreendida, em seu conjunto, como uma insurreição contra os poderes da normalização. Foucault permite tomar as noções de norma e de normalização como conceitos operatórios para pensar e ver de outras maneiras, para operar historicamente e circunscrever acontecimentos singulares - referentes à instituição e relações de poder específicas - ao mesmo tempo que ajuda a tornar visíveis certas circunstâncias atuais e a refletir sobre o que estamos fazendo hoje em nossa sociedade.

Ao pesquisar, em sua genealogia desenvolvida nos anos 70, as condições externas de possibilidade da existência e da formação do saber das ciências do homem na modernidade - como a educação, a psicologia, a psiquiatria, a psicanálise, a sociologia -, Foucault indaga as formas de poder que têm por alvo o sujeito, considerando esse saber como um dispositivo de natureza essencialmente estratégica. Essa pesquisa histórica objetiva mostrar de que maneira as práticas sociais podem constituir domínios de saber, que fazem aparecer formas totalmente novas de sujeitos e de sujeitos de conhecimento. A proposta é especificar como pode se formar, no século XIX, um certo saber 
do homem, da individualidade, do indivíduo normal ou anormal, dentro ou fora da regra, a partir de práticas sociais do controle, da vigilância e do exame, que se relacionam com a formação e estabilização da sociedade capitalista. ${ }^{79}$

Em Vigiar e Punir e em História da Sexualidade1, são apontadas relações entre estas ciências e as relações de poder, para explicar o surgimento de uma nova forma de dominação constituída com o capitalismo, cujo exercício não se reduz à violência nem à repressão, mas é produtivo, transformador, e se exerce em toda sociedade através de uma rede de micropoderes. É esta forma de dominação que Foucault torna visível, apontando seus perigos.

Foucault estuda a constituição, a partir do século XVIII, de saberes e práticas que ordenam as multiplicidades humanas e objetivam o sujeito, individualizando-o e homogeneizando as diferenças através da disciplina e da normalização - práticas de divisão do sujeito em seu interior e em relação aos outros. São saberes e práticas que atingem a realidade mais concreta do indivíduo, seu corpo, e que, devido à sua estratégia de expansão por toda a população, funcionam como procedimentos abrangentes de inclusão e exclusão social, que constituem um processo de dominação com base no binômio normal e anormal. "Esse processo o objetiva. Exemplos: o louco e o são, o doente e o sadio, os criminosos e os bons meninos" (Foucault, 1995: 231).

A questão dos saberes e dos poderes que objetivam o sujeito foi levantada e criticada por Foucault do ponto de vista da teoria do sujeito, bem como da teoria do poder. O que lhe importa, na época em que desenvolve essa crítica, é tentar ver como se constitui um sujeito não é dado definitivamente e que se constitui historicamente como efeito de um conjunto de estratégias que fazem parte das práticas sociais.

Tal tentativa baseia-se, conforme afirma em A Verdade e as Formas Jurídicas (1999), na idéia de que a teoria do sujeito foi modificada no século XX por certas teorias e por certas práticas, dentre as quais se incluem o marxismo europeu e a psicanálise. Ele considera a psicanálise como a prática e a teoria

\footnotetext{
${ }_{79}$ Em A Verdade e as Formas Jurídicas, Foucault explicita a diferença entre seu projeto e o marxista: "existe uma tendência que poderíamos chamar, um tanto ironicamente, de marxismo acadêmico, que consiste em procurar de que maneira as condições econômicas de existência podem encontrar na consciência dos homens o seu reflexo e expressão. Parece-me que essa forma de análise, tradicional no marxismo universitário da França e da Europa, apresenta um defeito muito grave: o de supor, no fundo, que o sujeito humano, o sujeito de conhecimento, as próprias formas do conhecimento são de certo modo dados prévia e definitivamente, e que as condições econômicas, sociais e políticas da existência não fazem mais do que se depositar ou se imprimir neste sujeito definitivamente dado" (Foucault, 1999: 8).
} 
que reavaliaram mais profundamente a prioridade "sagrada" conferida ao sujeito pelo pensamento ocidental desde Descartes. A psicanálise questionou essa posição absoluta do sujeito como fundamento de todo conhecimento, como aquilo a partir de que a liberdade e a verdade se revelam. Contudo, para Foucault, ainda continua muito "cartesiana e kantiana” porque ainda está presa a um sujeito da representação, um ponto de origem a partir do qual o conhecimento é possível, a verdade aparece.

O projeto genealógico desembaraça-se de uma interpretação jurídica e negativa do poder - caso em que poder significa lei, interdição, soberania e negação de liberdade -, para trabalhar com outra chave de interpretação histórica do poder, em que este significa norma, produção e afirmação das resistências como forças imanentes e não exclusivamente repressão e não saber ou ideologia.

Aqui, convém lembrar sua explicação: nas sociedades capitalistas, o poder é negativo e repressivo, porém possui uma eficácia produtiva; possui a positividade da gestão da vida dos indivíduos e das populações, para a qual produz uma série de estratégias, técnicas e saberes específicos. Sua positividade consiste, do ponto de vista do conhecimento, na produção de saberes que geram poderes e de estratégias de poder que geram saberes para assegurar seu exercício; do ponto de vista da ação, consiste na produção de indivíduos e populações politicamente dóceis, economicamente úteis, saudáveis e normais, através de uma série de mecanismos como os da disciplina e da normalização.

A genealogia foucaultiana evidencia o caráter peculiar às formas de exercício do poder em nossa sociedade: nas sociedades contemporâneas ocidentais, o poder assume formas regionais e concretas extremamente eficientes, com o objetivo de fazer do indivíduo e da população entidades normais e saudáveis.

A estratégia dessa forma de poder que se exerce a partir do século XVIII - a constituição de uma sociedade sadia e de uma economia social - liga-se ao projeto de prevenção e de transformação do anormal em indivíduo normal, através de saberes criados para este fim, como o da pedagogia.

O problema que essa concepção de poder levanta é que, se o poder tem mesmo uma capacidade de controle e uma eficácia produtiva tão penetrantes e abrangentes quanto Foucault demonstra em suas análises da disciplina e da normalização, torna-se muito difícil localizar regiões de resistência e de inovação que possibilitem a constituição de sujeitos autônomos, comprometendo sobremaneira os projetos institucionais de uma inclusão social ampliada e eficaz do normal - bem como do anormal - através de novas práticas. As 
práticas de inclusão institucional precisarão, através da resistência, das lutas pontuais e da criação, situar-se às margens das formas políticas instauradas para não terminarem por reproduzir e reforçar, sob a ilusão da mudança, os procedimentos de normalização e objetivação do sujeito - que barram a subjetivação - e que Foucault e Canguilhem tornam visíveis.

Vejamos alguns detalhes do argumento em Vigiar e Punir. Aí, Foucault faz ver que diversos procedimentos disciplinares já existiam há muito tempo nos conventos, nas forças armadas, nas oficinas. Mas, a partir do século XVII, as disciplinas foram se tornando fórmulas gerais de dominação. Foucault especifica historicamente o exercício do poder capitalista através da análise da disciplina em diversas instituições, como a prisão e a escola.

A disciplina organiza o espaço através de uma repartição dos indivíduos; controla a atividade através do controle do tempo; especifica o indivíduo generalizando-o através de uma vigilância hierárquica; organiza as diferenças através de uma sanção normalizadora e reproduz e produz saber através do exame.

A idéia de espaço educativo corresponde à instauração de internatos, quando se considerava que para educar era preciso isolar a criança num espaço ele mesmo transformador. Mesmo abandonando-se, mais tarde, o princípio de que era necessário o isolamento num espaço educativo para transformar as crianças, mantém-se, na escola, essa noção de espaço transformador, devido às suas divisões internas e à ordem por ele criada, através de seu caráter celular e serial.

As disciplinas, organizando as 'celas', os 'lugares' e as 'fileiras' criam espaços complexos: ao mesmo tempo arquiteturais, funcionais e hierárquicos. São espaços que realizam a fixação e permitem a circulação; recortam segmentos individuais e estabelecem ligações operatórias; marcam lugares e indicam valores; garantem a obediência dos indivíduos, mas também uma melhor economia do tempo e dos gestos. São espaços mistos: reais, pois regem a disposição de edifícios, de salas, de móveis, mas ideais, pois projetam-se sobre essa organização caracterizações, estimativas, hierarquias. (Foucault, 1987: 126)

Os conventos forneceram o modelo da célula que esquadrinha o espaço, tornando-o analítico, permitindo correlacionar o indivíduo e o lugar a ser ocupado por ele. A série reparte os indivíduos na ordem escolar, criando uma hierarquia entre as classes nas salas de aula, no recreio, nas tarefas, nas disciplinas, nas idades.

A organização de um espaço celular e serial, afirma Foucault, funcionou como condição de possibilidade do controle simultâneo de um grande número 
de alunos, através da classificação de cada um, que individualiza o conjunto heterogêneo de indivíduos. Na modernidade, o espaço celular e serial resolveu, na prática, o problema da falta de controle do conjunto dos alunos que ficavam às soltas, enquanto uma lição individual estava sendo ministrada. A série permite a repartição dos indivíduos na ordem escolar, hierarquizandoos em classes em que o trabalho simultâneo é realizado por todos que a ela pertencem, ordenando e especificando as multiplicidades.

Gesto e corpo são colocados em relação. O controle disciplinar não consiste simplesmente em ensinar ou impor uma série de gestos definidos, mas impõe a melhor relação entre um gesto e a atitude global do corpo, que é sua condição de eficácia e de rapidez. "Um corpo bem disciplinado forma o contexto de realização do mínimo gesto. Uma boa caligrafia, por exemplo, supõe uma ginástica - uma rotina cujo rigoroso código abrange o corpo por inteiro, da ponta do pé à extremidade do indicador" (Foucault, 1987: 130). A disciplina decompõe o ato em elementos, correlaciona o corpo com o gesto, articula o corpo com o objeto que manipula, e exercita os corpos com tarefas repetitivas, diferentes e graduais, através de uma utilização sempre crescente do tempo. A vigilância hierárquica é uma técnica fundamental para o exercício da disciplina, que opera por meio do olhar indiscreto, do princípio da total visibilidade.

Ao lado da grande tecnologia dos óculos, das lentes, dos feixes luminosos, unida à fundação da física e da cosmologia novas, houve as pequenas técnicas das vigilâncias múltiplas e entrecruzadas, dos olhares que devem ver sem ser vistos; uma arte obscura da luz e do invisível preparou em surdina um saber novo sobre o homem, através de técnicas para sujeitá-lo e processos para utilizá-lo. (Foucault, 1987: 144)

Trata-se de uma tecnologia para ocupar todos os espaços numa vigilância contínua das salas de aula, dos dormitórios, dos banheiros, exercida por fiscais perpetuamente fiscalizados - mestres, monitores, inspetores.

E se é verdade que sua organização piramidal lhe dá um chefe, é o aparelho inteiro que produz poder e distribui os indivíduos nesse campo permanente e contínuo. $\mathrm{O}$ que permite ao poder disciplinar ser absolutamente indiscreto, pois está em toda parte e sempre alerta (...). (Foucault, 1987: 148)

O poder disciplinar age através da sanção normalizadora, que é o caráter da disciplina analisado por Foucault para mostrar como as instituições cons- 
tituem seus próprios mecanismos de julgamento - pequenos julgamentos. A escola, por exemplo, funciona como um pequeno tribunal, com leis e infrações próprias para organizar as diferenças entre os indivíduos, atribuindo pequenas penalidades, bem como prêmios por merecimento. A sanção é normalizadora porque impõe a regra a todos os que dela se afastam, impõe

toda uma micropenalidade do tempo (atrasos, ausências, interrupções das tarefas), da atividade (desatenção, negligência, falta de zelo), dos discursos (tagarelice, insolência), do corpo (atitudes incorretas, gestos não conformes, sujeira), da sexualidade (imodéstia, indecência). (Foucault, 1987: 149)

A sanção é normalizadora porque faz funcionar a disciplina através do estabelecimento da norma, da medida que permite avaliar e julgar, normalizando por meio da comparação, da diferenciação, da hierarquização, da homogeneização e da exclusão. A partir do século XVIII, o normal se estabelece como princípio de coerção no ensino com a instauração de uma educação padronizada e a criação das escolas normais.

A sanção normalizadora é combinada com as técnicas da vigilância hierarquizada através do exame. O exame é um controle normalizador, uma vigilância que permite qualificar, classificar e punir. Como elemento dos dispositivos de disciplina, o exame é altamente ritualizado. Ele supõe um mecanismo que relaciona a formação de saber a uma certa forma de exercício de poder.

A escola é uma espécie de aparelho de exame ininterrupto que acompanha em todo o seu comprimento a operação do ensino. $\mathrm{O}$ exame permite que o mestre, ao mesmo tempo que transmite o saber, forme um campo de conhecimentos sobre os alunos: "o exame é na escola uma verdadeira e constante troca de saberes: garante a passagem dos conhecimentos do mestre ao aluno, mas retira do aluno um saber destinado e reservado ao mestre. A escola torna-se o local de elaboração da pedagogia” (Foucault, 1987: 155).

O exame é uma técnica tanto de poder como de saber; por esta razão, orienta a hipótese de Foucault segundo a qual o saber é diferente da ideologia e o poder é diferente da repressão, pois ambos seriam puramente negativos, e o que Foucault mostra é a positividade do poder. Ele aponta três características do exame que convém notar. Primeiramente, o exame inverte a economia da visibilidade no exercício do poder:

tradicionalmente, o poder é o que se vê, se mostra, se manifesta e, de maneira paradoxal, encontra o princípio de sua força no movimento com o qual a exibe. (...) O poder disciplinar, ao contrário, se exerce 
tornando-se invisível: em compensação impõe aos que submete um princípio de visibilidade obrigatória. (Foucault, 1987: 156)

Em segundo lugar, o exame faz a individualidade entrar num campo documentário: "seu resultado é um arquivo inteiro com detalhes e minúcias que se constitui ao nível dos corpos e dos dias. O exame que coloca os indivíduos num campo de vigilância situa-os igualmente uma rede de anotações escritas" (Foucault, 1987: 157).

Em terceiro lugar, o exame faz de cada indivíduo um caso que constitui um objeto para o conhecimento e uma tomada para o poder:

O caso não é mais, como na casuística ou na jurisprudência, um conjunto de circunstâncias que qualificam um ato e podem modificar a aplicação de uma regra, é o indivíduo tal como pode ser descrito, mensurado, medido, comparado a touros e isso em sua própria individualidade; e é também o indivíduo que tem que ser treinado ou retreinado (...). (Foucault, 1987: 158)

Essa transcrição das existências reais de cada um funciona como um processo de objetivação e de sujeição, portanto de fabricação da individualidade celular, orgânica, genética e combinatória, que têm a norma e os desvios como referência. Foucault observa que, num sistema de disciplina, a criança é mais individualizada do que o adulto, o doente mais do que o homem saudável, o louco e o delinqüente mais do que o normal.

Através da disciplina surge o poder da norma. O normal se estabelece, em vários campos, como princípio de coerção: no ensino, com a instauração de uma educação padronizada e a criação de escolas normais; no esforço para organizar um corpo médico e um quadro hospitalar da nação capazes de fazer funcionar normas gerais de saúde e na regularização dos processos e dos produtos industriais, por exemplo.

Do mesmo modo que a vigilância disciplinar, a normalização torna-se um dos grandes instrumentos de poder, a partir do final da época clássica. A normalização, tanto para Foucault como para Canguilhem, constrange para homogeneizar as multiplicidades, ao mesmo tempo que individualiza, porque permite as distâncias entre os indivíduos, determina níveis, fixa especialidades e torna úteis as diferenças.

As normas visam a integrar todos os aspectos de nossas práticas num todo coerente, para que diversas experiências sejam isoladas e anexadas como domínios apropriados de estudo teórico e de intervenção. No interior desses domínios, as normas não são estáticas, mas se ramificam a 
fim de colonizar, nos seus mínimos detalhes, as micropráticas, de modo que nenhuma ação considerada importante delas escape:

Compreende-se que o poder da norma funcione facilmente dentro de um sistema de igualdade formal, pois, dentro de uma homogeneidade que é a regra, ela introduz, como um imperativo útil e resultado de uma medida, toda a gradação das diferenças individuais. (Foucault, 1987: 154)

O que caracteriza a biopolítica das populações, o biopoder, é a crescente importância da norma, que distribui os vivos num campo de valor e utilidade. A própria lei funciona como norma devido a suas funções reguladoras. Uma sociedade normalizadora é o efeito histórico de técnicas de poder centradas na vida. A principal característica das técnicas de normalização consiste no fato de integrarem no corpo social a criação, a classificação e o controle sistemático das anormalidades.

Em Vigiar e Punir e em A Vontade de Saber 1, Foucault aponta não só o modo peculiar de funcionamento das normas modernas, impondo uma rede uniforme de normalidade, como também o mal-estar que esta causa. Dentre as técnicas, as práticas, os saberes e discursos por ele analisados, a normalização constitui um alvo bastante importante, pois todas as sociedades têm normas de acordo com as quais socializam os indivíduos. O problema apontado por Foucault é que, em nossa sociedade, as normas são especificamente perigosas, já que funcionam, de modo muito sutil, como estratégias sem estrategista.

A questão desenvolvida por Foucault - a respeito das formas de ação do poder investidas na sociedade moderna ocidental - deve ser analisada em seu enraizamento nas reflexões de Canguilhem acerca da norma e de seu caráter relacional. ${ }^{80}$ Tal enraizamento deve ser levado a suas últimas conseqüências, ao ser enfocada a ligação da genenalogia do poder com o argumento apresentado em "Do social ao vital" (Canguilhem, 2002).

\section{PrincíPIO DE INVERSÃO E POLARIDADE DA NORMA SEGUNDO CAnguilhem $^{81}$}

Ao estudar o caráter de sanção normalizadora da disciplina, Foucault toma como ponto de partida a afirmação de Canguilhem, de que o termo normal designa, a partir do século XIX, o protótipo escolar e o estado de

\footnotetext{
${ }^{80}$ Foucault faz tal afirmação, ao analisar os procedimentos constitutivos do poder disciplinar, no capítulo "Sanção normalizadora" de Vigiar e Punir. Ali, ele explicita que sua concepção de norma é tributária do conceito cunhado por Canguilhem (2002) em "Do social ao vital".

${ }^{81}$ Este item é um extrato do artigo publicado em Educação $\mathcal{E}$ Realidade (Portocarrero, 2004).
} 
saúde orgânica. Sua utilização é correlata da reforma pedagógica e da teoria médica, estreitamente ligadas à reforma das práticas pedagógica, médica e hospitalar. Essas reformas exprimem uma exigência de racionalização que também aparece na política e na economia, alcançando o que é chamado mais tarde de normalização.

Em "Novas reflexões referentes ao normal e ao patológico" - texto privilegiado por Foucault em Vigiar e Punir -, Canguilhem (2002) especifica o normal social, distinguindo-o do normal vital. Enquanto a exigência das normas do organismo é interna e imanente à própria possibilidade de vida, a normalização que se estabelece na sociedade deve-se a uma escolha e a uma decisão exteriores ao objeto normalizado, mesmo que não haja consciência - por parte dos indivíduos - de que se trata da expressão de exigências coletivas, estabelecidas a partir do modo de relação de uma dada estrutura social e histórica com aquilo que se considera como seu bem particular.

Em O Normal e o Patológico, pode-se depreender uma relação estabelecida por Canguilhem entre a vida, a norma, o corpo, a saúde e o sujeito. Para ele, o que caracteriza a especificidade da norma - imanente ao fenômeno vital - é a plasticidade da vida; a necessidade própria da vida de criação e instauração de novas normas vitais e seu caráter de luta, seu caráter dinâmico e inventivo, que serve como princípio de avaliação do estado de saúde do indivíduo. Nesse sentido, pode-se dizer que o vivente é instituidor de normas e torna-se sujeito por sua capacidade como ser vivo de confrontá-las e ultrapassá-las sempre que o meio exigir.

Ele inverte o pensamento sobre a saúde. Primeiro, porque coloca a questão do organismo como ser vivo sem supor que este mantém uma relação de harmonia preeestabelecida com o meio; segundo, porque coloca o sofrimento - não a mensuração normativa ou o desvio padrão - como o elemento que estabelece o estado de doença. Canguilhem faz, assim, um ataque frontal ao edifício da normalização, essencial para o desenvolvimento de uma ciência e de uma medicina positivistas.

Sua crítica se dirige não só ao ensino médico - que privilegia o normal e a normalidade e considera a doença um desvio de normas fixas, que seriam as constantes -, mas também à prática médica que busca estabelecer cientificamente tais normas; critica-os em seu objetivo de trazer o organismo de volta ao estado de saúde, com o restabelecimento da norma anterior, da qual o organismo teria se afastado, pois tal norma não pode ser restabelecida, visto 
que uma nova norma se instaura. Para Canguilhem, o organismo é normativo, ou seja, não é fixo e instaura sempre novas normas.

Sendo a normatividade própria do ser vivo, a normalidade consiste na capacidade de adaptação, de variação do organismo às mudanças circunstanciais do meio externo ou interno, que, por sua vez, é variável. A doença, ao contrário da saúde, é que constitui uma redução a constantes. Essa inversão realizada por Canguilhem faz com que aquilo que caracterizava a normalidade - normas estáveis, valores imutáveis, constantes - caracterize também a doença. A singularidade da saúde é, portanto, a possibilidade de transcender a norma que define a normalidade momentânea; é a possibilidade de tolerar as infrações da norma habitual e instituir novas normas em situações novas.

A necessidade vital da regulação normativa imanente ao objeto normatizado - por exemplo, para o fisiologista, o peso normal do homem, levando em conta o sexo, a idade e a estatura, é o peso que corresponde à maior longevidade previsível - desaparece diante do arbitrário social da decisão normativa. Assim, uma escola normal, uma escola onde se ensina a ensinar, é onde se instituem experimentalmente métodos pedagógicos normalizados e normalizadores. A normalização dos meios técnicos da educação - como dos da saúde, do transporte de pessoas e de mercadorias - é a expressão de exigências coletivas. Só há normalização social porque a sociedade se define como um conjunto de exigências coletivas articuladas em torno de uma estrutura diretriz que define seu bem singular.

O importante no pensamento de Canguilhem é que, no social, a norma deixa de valer como regulação interna e passa a valer como prescrição e valoração. A transformação de um objeto em norma supõe uma decisão normalizadora, mas essa decisão só se efetiva relativamente a uma intenção normativa, que confere ao objeto dignidade e valor. A atividade assim regulada é uma tarefa dinâmica, incerta, arbitrária e conflituosa. $\mathrm{O}$ conflito das normas no campo social liga-se não a seu caráter de contradição, mas ao caráter de luta e transformação que o constitui. Nesse sentido, a guerra social é pensada primeiramente como uma guerra das normas, devendo ser compreendida como uma guerra de valores que subentende as normas, inscrevendo-se no campo da existência e entrando ou não em conflito com as normas já existentes.

Em “Do social ao vital”, Canguilhem explica: a valoração que caracteriza um objeto ou um fato considerado normal é sua função de referência. $\mathrm{O}$ normal é ao mesmo tempo a extensão e a exibição da norma. O normal multiplica a 
regra ao mesmo tempo que a indica. Requer, portanto, fora dele, a seu lado e contra ele, tudo aquilo que ainda lhe escapa.

O autor considera, com Bachelard, que o normal não é um conceito estático ou pacífico, mas dinâmico e polêmico. Ele ressalta o interesse de Bachelard pelos valores cosmológicos e populares - pela valoração que se estabelece a partir da imaginação - bem como sua percepção de que todo valor tem de ser obtido em oposição a um antivalor:

Uma norma, uma regra, é aquilo que serve para retificar, pôr de pé, endireitar. Normar, normalizar é impor uma exigência a uma existência, a um dado, cuja variedade e disparidade se apresentam, em relação à exigência, como um indeterminado hostil, mais ainda do que estranho. (Canguilhem, 2002: 211)

Para Canguilhem (2002: 211), a origem latina da palavra norma é esclarecedora:

Quando se sabe que norma é a palavra latina que quer dizer esquadro e que normalis significa perpendicular, sabe-se praticamente tudo o que é preciso saber sobre o terreno de origem do sentido dos termos norma e normal trazidos para uma grande variedade de outros campos.

O conceito de norma é necessariamente relacional: normal/anormal. Trata-se de uma relação de polaridade e de inversão dos pólos, não de uma relação de contradição nem de exterioridade, já que a norma é um conceito que qualifica negativamente o setor do dado que não se inclui em sua extensão, ao mesmo tempo que depende dele para sua própria compreensão.

Tal polaridade da experiência de normalização (experiência especificamente antropológica e cultural) funda, na relação da norma com seu domínio de aplicação, a prioridade da infração, pois a regra só começa a ser regra ao constituir-se como regra e como tendo uma função de correção que surge da própria infração. Sem infração não há regra.

O sonho de uma regularidade sem regra, como a idade de ouro, o paraíso, são figurações míticas de uma existência inicialmente adequada à sua exigência, de um modo de vida cuja regularidade nada deve à determinação de uma regra, de um estado de não-culpabilidade com a inexistência de proibição que ninguém devesse ignorar, explica Canguilhem (2002: 213).

Estes dois mitos procedem de uma ilusão de retroatividade segundo a qual o bem original é o mal ulterior contido. (...) O homem da idade 
do ouro e o homem paradisíaco gozam espontaneamente dos frutos de uma natureza inculta, não solicitada, não corrigida.

Trata-se de um sonho ingênuo, em que a formulação, em termos negativos, de uma experiência conforme à norma, sem que a norma tivesse que se manifestar na sua função normalizadora, significa que o próprio conceito de norma é normativo.

A definição do anormal é a negação lógica do normal. Contudo, é a anterioridade histórica do futuro anormal que suscita uma intenção normativa. Não há, portanto, de acordo com Canguilhem, nenhum paradoxo em afirmar que o anormal é logicamente o segundo, mas o primeiro, do ponto de vista da existência.

Ao depreciar tudo aquilo que a referência à norma proíbe de ser considerado normal, a norma cria a possibilidade de uma inversão dos termos. Uma norma corresponde a uma proposta de unificação do diverso, que não tem nenhum sentido isoladamente. Sua possibilidade mesma de ser referência e regulação contém sempre, por se tratar apenas de uma possibilidade, uma outra possibilidade que só pode ser inversa.

Com efeito, uma norma só pode ser referência se ela foi instituída ou escolhida como expressão de uma preferência e como instrumento da vontade de substituição de um estado de coisas, pelo qual se tem aversão, por um outro considerado preferivel.

Ressalte-se que a conformidade à norma requer a experiência prévia de um certo vazio normativo, em que as multiplicidades das distâncias preexistem à unidade da série normativa, sendo a alteridade à norma tida como a variedade social que escapa à normalização. A proposta de uma norma é um modo possível de unificação de um diverso, de reabsorção e de regulação de uma diferença.

Numa organização social, (...) as regras devem ser representadas, aprendidas, rememoradas, aplicadas. Ao passo que, num organismo vivo, as regras de ajustamento das partes entre si são imanentes, presentes sem ser representadas, atuantes sem deliberação nem cálculo. Não há, neste caso, desvio, distância, nem intervalo de tempo entre a regra e a regulação. A ordem social é um conjunto de regras com quais seus servidores ou seus beneficiários têm que se preocupar. A ordem vital é constituída por um conjunto de regras vividas sem problemas. (Canguilhem, 2002: 222)

Para Canguilhem, a norma é menos unificadora do que reguladora. Ela organiza as distâncias, tentando reduzi-las a uma medida comum, restando, contudo, a possibilidade de inversão da norma: ao impor uma exigência e a 
unificação do diverso, a norma pode-se inverter em seu contrário ou em outra norma, em nova norma.

É importante ressaltar que, segundo o autor, é possível compreender a norma social, como a expressão de uma vontade coletiva que pode ser interrompida por uma normatividade individual para a qual a valorização de um outro estado de coisas engendra uma nova possibilidade de transformação do terreno já existente da vida social. Desse modo, as normas sociais determinam a ação do indivíduo parcialmente, pois a mecanização do sistema social deixa margens, cria zonas vazias, que somente um sujeito, cujo projeto é inventar suas próprias normas, pode delas se apropriar.

Só há sujeito para Canguilhem porque há, simultaneamente, sujeição às normas que objetivam o sujeito, e subjetivação dessas mesmas normas. $\mathrm{O}$ sujeito é um efeito das normas, porém, um efeito original, pois se efetua a si mesmo, delas distanciando-se. A distância torna-se a condição normativa do sujeito. $\mathrm{O}$ ato de subjetivação por excelência é o afastamento das normas; sua condição de possibilidade é a capacidade normativa da distância.

Foucault parte do enraizamento em Canguilhem para mostrar, a seu modo, como práticas sociais podem engendrar saberes que não somente fazem aparecer novos objetos, novos conceitos, novas técnicas, mas também objetivam o sujeito, fazendo nascer formas totalmente novas de sujeitos; para mostrar como se pôde formar, no século XIX, um certo saber do homem, da individualidade, do indivíduo normal ou anormal, dentro ou fora da regra, saber esse que, na verdade, nasceu de práticas sociais divisoras do indivíduo.Tal questão tem suscitado, nos últimos anos, inúmeras análises e polêmicas, no campo do direito, da ética, da política e das ciências do homem na modernidade.

Ao discutir a questão do sujeito em Canguilhem e Foucault, Guilhaume Le Blanc (1998), por exemplo, aponta uma afinidade e uma diferença entre estas duas perspectivas. Uma afinidade: na sociedade disciplinar moderna, analisada por Foucault, as normas passam pelo espírito e pelo corpo; não havendo nenhuma possibilidade de sair do jogo normativo, o indivíduo não pode jamais liberar-se das normas. No interior das normas, mantêm-se as distâncias individuais, que são teóricas e práticas, restando possibilidade teórica de compreender-se como pertencente às normas e elaborar os conceitos adequados à produção normativa interna do saber. Para o último Foucault, é possível, na prática singular da amizade, inventar uma relação não normalizada com o outro, visto que os amigos inventam formas de relações 
singulares. Os modos de vida dos amigos podem fazer surgir sistemas não normativos entre os seres.

Uma diferença: o homem normativo é definido por Canguilhem segundo seu poder inventivo, criador de novas normas. Esta possibilidade está ausente da análise de Foucault. De acordo com a leitura de Le Blanc, pode-se, nas normas existentes, colocar entre parênteses a disciplina normativa na prática da amizade; em troca, não se podem inventar novas normas, o que seria sair das normas existentes. A transgressão das normas existentes é uma impossibilidade para Foucault, sendo a experiência literária a única experiência da transgressão objetivada pelo filósofo. Uma subversão das normas torna-se, em troca, possível com Canguilhem, a partir do momento em que o homem normativo tem a possibilidade de quebrar as normas e de instituir novas.

Encontramos com freqüência, nos últimos anos, o desenvolvimento dessa questão, a partir da hipótese de uma solução ética foucaultiana para o problema da inelutabilidade do controle social sobre o sujeito, face à eficácia do exercício do poder disciplinar e normalizador das sociedades contemporâneas. Esse problema é levantado principalmente pela esquerda marxista, que critica duramente sua noção de poder, nela apontando uma visão niilista, segundo a qual não haveria lugar nem para a resistência nem para a liberdade.

Uma solução residiria nas idéias de técnicas de si, de cuidado de si, de governo de si, de arte de não ser governado e no conceito de governo, estudados no último Foucault. É certo que a noção de governo, delineada a partir do final dos anos 70, como um determinado tipo de relações entre indivíduos, uma forma social de relação junto a outras, como uma ação que se exerce sobre a ação dos outros e sobre si mesmo constitui uma contribuição para a discussão aqui proposta. Porém, é possível, do ponto de vista de sua genealogia do poder - desenvolvida na década de 1970 -, vislumbrar soluções, se a referência de Foucault às reflexões de Canguilhem sobre a normalização for levada a sério e às últimas conseqüências e se a estas reflexões se combinarem alguns elementos da concepção de poder como resistência, conforme explicitada em História da Sexualidade 1.

Em primeiro lugar, a idéia de que onde há poder há resistência; negá-lo seria desconhecer o caráter estritamente relacional das correlações de poder, que só podem existir em função de uma multiplicidade de pontos de resistência que representam, nas relações de poder, o papel de adversário, de alvo, de apoio, de saliência. 
Em segundo lugar, de acordo com Foucault, esses pontos de resistência estão presentes em toda a rede de poder. As resistências são singulares e podem ser necessárias, improváveis, possíveis, espontâneas, selvagens, solitárias, planejadas, arrastadas, violentas, irreconcialiáveis, prontas ao compromisso, interessadas ou fadadas ao sacrifício. Por definição, as resistências só não podem existir no campo estratégico das relações de poder, mas isso não quer dizer que sejam apenas subprodutos das mesmas, sua marca em negativo, formando, por oposição à dominação essencial, um reverso inteiramente passivo, fadado à infinita derrota. Ao contrário, por serem o outro termo nas relações de poder, elas se inscrevem nessas relações como interlocutor irredutível: "elas introduzem na sociedade clivagens que se deslocam, rompem unidades e suscitam reagrupamentos, percorrem os próprios indivíduos, recortando-os e remodelando, traçando neles, em seus corpos e almas, regiões irredutíveis" (Foucault, 2001a: 92).

Em terceiro lugar, a afirmação de Foucault de que assim como a rede das relações de poder acaba formando um tecido espesso, atravessando os aparelhos e as instituições sem se localizar exatamente neles, também a pulverização dos pontos de resistência atravessa as estratificações sociais e as unidades individuais. 



\section{Dos Ensaios sobre Epistemologia, Arqueologia e Genealogia}

Este foi o nível em que se situaram minhas análises: o das formas de problematização da vida e das ciências da vida. Apesar de sua heterogeneidade, as formas de problematização privilegiadas tangenciam-se, permitindo configurar uma preocupação e estabelecer uma certa unidade, pois dirigem-se às ciências da vida e ao conceito de vida a partir do pressuposto da historicidade da ciência, do conceito, do saber e do poder. Complementares ou contraditórias entre si, são estratégias históricas que buscam continuidades e descontinuidades, ainda que sua natureza e seu estatuto sejam específicos a cada uma das estratégias, situando-as em níveis diferentes.

A perspectiva apresentada foi, como podemos ver nos ensaios, a do caleidoscópio. O que quero dizer é que o conjunto heterogêneo das abordagens analisadas vai mudando de configuração à medida que giramos o caleidoscópio - as repetições de autores e conceitos nunca são, exatamente, repetições. A cada problema que se coloca - o do vitalismo, o da representação, o do objeto empírico, o da diferenciação dos níveis de análise da epistemologia e da arqueologia, ou da genealogia - modifica-se de acordo com a posição que cada abordagem ocupa em relação às outras. Desta forma, os pensamentos nunca se dão de uma vez; eles vão sendo retomados e se superpondo. A cada movimento, é mais uma dimensão das formas de problematizar as ciências da vida que se evidencia.

Foi assim que reuni, sem reduzir umas às outras, análises como as de Canguilhem, Latour e Salomont-Bayet, estabelecendo correlações. Diante do problema das ciências da vida, a epistemologia de Canguilhem, que se aproxima da história de Jacob, se diferencia da genealogia de Latour, que por sua vez se 
relaciona com a de Foucault, cuja arqueologia estabelece deslocamentos em relação à epistemologia, como fica claro na primeira parte deste livro.

Na segunda parte, a pesquisa apresentou uma perspectiva vertical, dirigindo-se à especificação de três níveis: o da epistemologia, o da arqueologia e o da genealogia. No nível da análise epistemológica, as descontinuidades históricas são diacrônicas. Marcam incompatibilidades e mutações, em épocas diferentes, através da recorrência estabelecida a partir do critério da atualidade. Nos níveis arqueológico e genealógico da analítica do poder, trata-se de descontinuidades diacrônicas, que traçam o limiar de épocas diferentes, mas articuladas a continuidades sincrônicas que marcam compatibilidades e coerências numa mesma época, através não do critério da recorrência e da atualidade, mas da positividade e da contemporaneidade dos saberes e dos poderes.

Da questão da ciência e da metodologia histórica, a pesquisa passou à investigação de descontinuidades específicas que situam a história do conceito de vida e do surgimento da biologia em níveis específicos. Primeiramente, aquelas estabelecidas por formas de problematização que conduziram ao problema do vitalismo, no nível epistemológico e no nível arqueológico.

Aí, evidenciou-se que, nestes dois níveis de análise, desenvolve-se uma visão oposta do vitalismo - como conceito operatório nas ciências da vida, como para Canguilhem e Jacob, ou, ao contrário, como efeito de superfície do nível 'profundo' da arqueologia, onde não pode ser considerado conceito operatório. Contudo, as análises se complementam com projetos de pesquisa diferentes. Esta complementação, que mantém a singularidade de cada projeto, torna-se muito clara, como explicito ao longo do livro, devido não só às diferenças específicas de cada um, mas à coincidência, nestes dois níveis, de elementos que configuram as descontinuidades por eles apontadas, embora a própria concepção de descontinuidade epistemológica e arqueológica não seja a mesma.

Como se evidencia, os pontos de coincidência são inúmeros: a forma do conhecimento científico e filosófico da época clássica como sendo a mesma, a da representação; a sua incompatibilidade com a forma do conhecimento das ciências empíricas, como as biomédicas, e da filosofia na modernidade, pertencentes a dois diferentes níveis de conhecimento, o dos conhecimentos empíricos e o da filosofia transcendental; a explicitação dos conteúdos da história natural e da medicina clássica, os seres vivos e a doença, como entidades abstratas, ideais; a sua incompatibilidade com os conteúdos da biologia e da medicina moderna, com a vida empírica, concreta, e a doença no corpo con- 
creto do indivíduo; o papel de Cuvier - e não de Lamarck - como marco da biologia, o de Bichat, da medicina, e o de Kant, da filosofia na modernidade; a constituição do conceito de vida somente na modernidade.

No domínio das análises das ciências da vida, as maiores diferenças entre a arqueologia e a epistemologia são mesmo, do ponto de vista do método, as que dizem respeito à natureza e ao estatuto da descontinuidade; do ponto de vista do conteúdo, as que dizem respeito ao valor do vitalismo para a história das ciências da vida e seu papel na articulação entre a filosofia, a ciência e a vida.

Mas esta diferença não pode ser subdimensionada nem superestimada. Ao considerar o vitalismo um conceito operatório, a análise conceitual, recorrente e judicativa termina por exigir da epistemologia que busque, através da relação da filosofia com a ciência, a confirmação de verdades essenciais, ainda que provisórias e parciais. Apesar das dificuldades, cada vez maiores, da posição vitalista, hoje, a própria biologia e sua forma de problematizar a vida permitem a Canguilhem confirmar a consistência de seu vitalismo. Dagognet, a partir do pensamento do próprio Canguilhem, desenvolve tal investigação, levantando a questão: "uma ciência da vida é possível?".

O sentido desta questão, formulada por Dagognet, é epistemológico. $\mathrm{Na}$ arqueologia, seu sentido só pode ser outro - como é possível que a ciência da vida exista, pois a arqueologia busca o nível das condições de possibilidade do saber, e não o da verdade e da atualidade. Também não é sua preocupação diferenciar o estatuto do vitalismo em relação à metafísica, à ciência, nem definir animismo, vitalismo, mecanicismo, como fazem, detalhadamente, Canguilhem e Jacob.

Aliás, o vitalismo e sua oposição ao mecanicismo não são considerados, em As Palauras e as Coisas, em seu caráter de debate ou de cientificidade. O mecanicismo só aparece na arqueologia para descartar a hipótese de que o que caracteriza a época clássica é o mecanicismo presente no racionalismo cartesiano; a tese foucaultiana é que o pensamento de Descartes é emblemático da época clássica por instaurar o pensamento da Ordem. Ao buscar estabelecer regras universais de conhecimento - mathesis universalis e taxonomia -, Descartes funda o conhecimento, em última instância, na ordenação das representações. E é por esta razão que deve ser considerado como fundando os procedimentos das ciências clássicas, como a história natural, a análise das riquezas e a gramática - conhecimentos que comparam e classificam, ordenando as representações -, não por sua relação com o mecanicismo, menos ainda por sua relação com a medida, com a matemática que se reduz à ordem. 
Se as descontinuidades são, no nível arqueológico, indispensáveis para definir os limites temporais do saber de uma época e, nela, o aparecimento de novas empiricidades, novos objetos e nova forma dos saberes, são as continuidades entre os diferentes saberes de uma época determinada que delimitam seu espaço geral. São as relações de diferentes ciências entre si e delas com a filosofia que permitem explicitar a configuração geral do saber numa episteme.

A pesquisa da noção da representação e da constituição do objeto, na modernidade, permitiu esclarecer esta descontinuidade. Apesar das severas críticas, dirigidas a categorias metodológicas da arqueologia como representação, episteme, a priori histórico, é possível esclarecer seu sentido e seu valor operatório para a história das ciências realizada por Foucault. As análises foucaultianas constituem instrumentos importantes para a determinação arqueológica das condições de possibilidade da constituição do saber moderno e sua crítica como saber antropológico.

É a partir desta idéia que o problema do conceito de vida é tratado aqui, buscando as formas de problematização que conduziram à interrogação das condições de possibilidade de seu surgimento na modernidade. Primeiro, discutindo a questão do limiar da modernidade, com Kant, e da articulação estabelecida, na arqueologia, da filosofia com as ciências empíricas, as da vida. Em seguida, analisando as formas de problematização da vida em suas condições externas de possibilidade, no nível da relação do saber com o poder, instituído com a analítica do poder. Porém, a questão analisada não se limitou ao problema do surgimento do conceito moderno de vida, uma vez que se voltou para a analítica do poder. Terminou por apontar, a partir do estudo das relações de poder que incidem sobre a vida dos indivíduos e das populações, na dimensão do governo - dos outros e de si mesmo -, os contornos da investigação genealógica em sua vertente ético-estética.

Se repostas definitivas e fechadas para os problemas levantados deixaram de ser apresentadas, isto não se deve à complexidade dos temas que se interligam nestes ensaios, nem à grande erudição de pensamentos que abrangem, simultaneamente, muitas teses, todas elas complexas, mas ao fato de que tal tarefa escaparia inteiramente ao propósito desta investigação. 
Apêndices 



\section{1 \\ Vida, Genealogia da Ética e Estética da Existência $^{82}$}

Ao dirigir sua investigação para o problema do governo e da governamentalidade para o das técnicas de si na Antigüidade helenística e romana, Foucault redireciona seu projeto de história da sexualidade - do homem do desejo - para a questão da vida humana e do si mesmo, concebendo-os como objetos de tecnologias que, do ponto de vista da racionalidade, podem ser comparadas a uma técnica de produção. Pode-se dizer que, a partir do final dos anos 70, ele elabora uma genealogia da ética que é uma estética da existência, uma pesquisa da maneira pela qual os indivíduos buscam formar, por meio de escolhas pessoais, modos de vida, "ethos de liberdade", em que a própria vida humana é um trabalho, uma obra de arte.

Esta dimensão ética explicita-se por meio de uma genealogia do homem do desejo, um trabalho histórico e crítico sobre a sexualidade, que concebe um elo entre sexo, subjetividade e verdade. Foucault observa que, contrariamente aos outros interditos, os interditos sexuais são sempre ligados à obrigação de o sujeito dizer a verdade sobre si mesmo. Ele desenvolve esta questão privilegiando a pesquisa dos modos de relação consigo, a partir da hipótese que a reflexão moral na Antigüidade greco-romana foi dominada pelo tema da prática de si. Trata-se de uma análise do modo pelo qual os homens se governam a si mesmos e aos outros através da produção de verdade.

Sua genealogia indaga, então, a maneira pela qual os indivíduos foram levados a elaborar sobre si e sobre os outros uma hermenêutica do desejo, com o objetivo de estudar de que maneira eles são conduzidos a reconhecer-

\footnotetext{
${ }^{82}$ Este Apêndice é uma adaptação do artigo originalmente publicado na revista Educação (Portocarrero, 2007).
} 
se como sujeitos de uma sexualidade, cuja história deve ser compreendida como experiência que correlaciona, numa cultura, campos de saber, tipos de normatividade e formas de subjetividade. Tal história só se realiza, de fato, em contraponto com o cristianismo primitivo, o estoicismo tardio e o pensamento grego clássico.

O estudo da formação da hermenêutica de si e de seu desenvolvimento é realizado em dois contextos diferentes: por um lado, o da filosofia greco-romana dos dois primeiros séculos do início do Império Romano; por outro, o da espiritualidade e dos princípios monásticos tais como se desenvolveram nos séculos IV e V. O sujeito é analisado por meio da noção de indivíduo e sua relação com um conjunto de práticas da Antigüidade tardia. Nos gregos, estas práticas tomaram a forma de um preceito: "cuidar-se", "preocupar-se consigo".

Por sua complexidade e por se encontrar dispersa em seus livros, ditos, escritos e cursos, esta questão é muito ampla, abrangendo inúmeros conceitos impossíveis de serem analisados em poucas linhas. Foucault discute muitos temas éticos, como autonomia, egoísmo, felicidade, liberdade, individualismo, prazer, austeridade etc. O tema da liberdade, por exemplo, é tratado, primeiramente, como imanente às relações de forças, na medida em que estas são por ele diferenciadas de uma relação de violência, em sua genealogia do poder, desenvolvida na década de 1970. Mais tarde, é tratado não só de uma pesquisa sobre o liberalismo em nossa sociedade que a coloca, paradoxalmente, como uma obrigação para o funcionamento do Estado liberal, como também do recuo histórico correlacionado à ascese antiga e a seu princípio de autotransformação e autodominação. O tema do individualismo, por exemplo, ao qual o projeto de uma genealogia do homem do desejo com ênfase no cuidado de si e no uso dos prazeres poderia conduzir - como criticam alguns especialistas fundamenta-se no caráter social necessariamente incluído nas práticas de si.

Esta questão será aqui apresentada, resumidamente, a partir da diferença teórico-metodológica estabelecida por Foucault entre ética e moral e sua relação com o domínio das práticas do cuidado de si.

A reflexão foucaultiana sobre a ética é apresentada em A História da Sexualidade 2, em História da Sexualidade 3, em uma série de escritos, entrevistas e conferências de finais da década de 1970, reunidos em Dits et Écrits e em seus cursos do Collège de France. Ela é de fundamental interesse para os problemas educacionais atuais, se for entendida como um recuo histórico cujo objetivo é fornecer elementos para compreendermos como nos tornamos o que somos hoje, e, sobretudo, o que estamos nos tornando. E isto não por meio de uma 
mitificação da Antigüidade como algo a ser transposto ao presente, mas como forma de questionar as evidências de nosso presente, suas falsas necessidades tanto no nível teórico como no nível das práticas, principalmente as educacionais. Os gregos não são uma solução para nós, explica Foucault. Até porque, dada a historicidade constitutiva das éticas e das formas de subjetivação, tal transposição seria impossível.

Ele se afasta das análises dos sistemas filosófico-morais que a ética coloca tanto em termos da legitimidade e dos limites dos códigos, como em termos dos comportamentos, dos direitos e dos deveres dos indivíduos ante estes sistemas. Sua pretensão é pensar uma ética tendo como eixo um outro elemento que a constitui - a relação dos indivíduos consigo mesmos - a partir de uma arte da vida. A relação da subjetividade com a verdade é buscada não no interior do conhecimento, como na tradição, mas na história.

Portanto, não se trata de dedicar-se à problemática do conhecimento, do fundamento do sujeito e da verdade, segundo o qual o sujeito conheceria verdades sobre o mundo, sobre si mesmo e sobre sua conduta. Mas às formas históricas em que foram tramadas, no Ocidente, as relações entre a subjetividade e a verdade fora do âmbito das teorias do conhecimento, através de um recuo até o regime dos comportamentos e prazeres sexuais na Antigüidade - não às idéias ou aos comportamentos propriamente, mas àquilo que os regulamenta: o regime dos aphrodisia ${ }^{83}$ - "era realmente no regime dos aphrodisia e de modo algum na moral cristã ou, pior, judaico-cristã, que se encontrava o arcabouço fundamental da moral sexual européia moderna" (Foucault, 2004: 4).

Este novo interesse afasta Foucault da hipótese sustentada até História da Sexualidade 1, onde afirma que, a partir do século XVIII, em vez de se instaurar apenas a repressão sexual, instaura-se todo um processo de produção, toda uma multiplicação dos discursos sobre o sexo no próprio campo do exercício do poder. Este projeto moderno de "colocação do sexo em discurso" e sua obstinação em constituir uma ciência da sexualidade, "sem dúvida através de muitos erros", "formara-se, há muito tempo, numa tradição ascética e monástica” (Foucault, 2001a: 18, 24), afirma ele, então.

\footnotetext{
${ }^{83}$ Aphrodisia são os prazeres do amor, as relações sexuais, os atos da carne, as volúpias etc. Porém, o termo grego não possui, em nossa moral, as mesmas funções que as noções de sexualidade (a partir do século XVIII) e de carne (até o século XVII). Não há, nos gregos, uma noção que reúna - como sendo da mesma natureza, origem ou tipo de causalidade - fenômenos diversos e afastados como sensações, imagens, desejos, instintos, paixões. Os gregos dispõem de uma série de palavras para designar diferentes gestos ou atos que nós chamamos "sexuais". Por isso, Foucault mantém em suas pesquisas o termo em grego.
} 
Porém, ao analisar a maneira pela qual é inventado, na Antigüidade grega e romana, um tipo de relação de si com o corpo e com o prazer, Foucault mostra sua irredutibilidade ao modelo cristão da decifração do desejo, rediscutindo a noção de ética e diferenciando-a de moral. A partir desta análise, ele concebe a ética como um modo de vida no qual bem e bom não são contraditórios entre si, em que o indivíduo e o outro não se sujeitam a elementos externos como regras transcendentais, princípios formais ou universalidades racionais prévia e definitivamente dadas. Seu objetivo é deslocar as fronteiras das morais vigentes para que o sujeito possa ser levado a se transformar, estilizando sua vida na presença do outro, amigo ou mestre virtuoso.

A moral é definida como um conjunto de valores e de regras de ação que são propostos aos indivíduos e aos grupos por intermédio de diferentes aparelhos prescritivos, como a família, as instituições educativas, as igrejas, os sistemas de leis, de prescrições do código moral. Ela produz uma moralidade dos comportamentos que corresponde a uma variação individual mais ou menos consciente, que é a maneira pela qual os indivíduos se submetem a um princípio de conduta, obedecem ou resistem a uma interdição ou prescrição, respeitam ou negligenciam um conjunto de valores.

A ética, por sua vez, é concebida como a maneira pela qual o indivíduo se transforma, constituindo-se como o próprio sujeito moral do código. A questão da ética é conduzida por Foucault com base na problematização dos processos históricos segundo os quais as estruturas de subjetivação ligaram-se a discursos de verdade, através de que se construíram, desde a Antigüidade, formas de subjetivação. Estas formas são um trabalho de modificação de si mesmas, ligado à Parrhesia, que Foucault traduz por "dizer verdadeiro".

O dizer verdadeiro é intrínseco às práticas de si, que são técnicas da Antigüidade grega voltadas para a vida considerada como uma obra de arte. Esta é uma a ética que diz respeito a uma estética da existência, uma arte de viver como governo da própria vida, cuja finalidade é dar-lhe a forma mais bela possível - uma das hipóteses mais interessantes de Foucault com relação a esta questão.

Em suas conferências proferidas na Universidade da Califórnia (Foucault, 2001b), Foucault apresenta seus estudos sobre a noção grega de Parrhesia, compreendida como práticas que envolvem um discurso que é uma verdade ligada à atitude de coragem, que se afirma, não devido a seu caráter lógico ou retórico, à sua habilidade argumentativa, mas devido a uma atitude de risco, de perigo, um modo de vida com o qual aquele que diz a verdade se acha comprometido. 
O dizer verdadeiro é imanente às práticas que, na Antigüidade grega, buscam uma existência bela, brilhante, heróica, por meio do cuidado de si, da elaboração de si, do governo de si - tema presente na reflexão moral desde o Alcibíades de Platão até Sêneca, Marco Aurélio, Epíteto. Sócrates, por exemplo, poderia ser considerado um parrhesiastes porque vivia de acordo com suas afirmações mesmo diante do risco da morte; sua coragem e austeridade no cuidado de si davam beleza à sua existência.

Ao traçar uma história das maneiras pelas quais, o homem, em nossa cultura, elabora um saber sobre si mesmo, Foucault analisa as técnicas utilizadas para fazê-lo em sua relação com as diferentes matrizes de razão prática. Por exemplo, as técnicas capitalistas de produção dos objetos; as técnicas dos sistemas de signos, que estabelecem a comunicação; as técnicas de poder, que determinam a conduta dos indivíduos, submetem-nos a certos fins ou à dominação, tornando-os objetos de poder e de saber, na modernidade; as técnicas de si, que permitem aos indivíduos efetuar, com a ajuda dos outros, um certo número de operações sobre o corpo e a alma, pensamentos, condutas, modo de ser, transformar-se a fim de alcançar um certo estado de felicidade, de pureza, de sabedoria, de perfeição ou de imortalidade (Foucault, 2001b).

Estas técnicas não funcionam separadamente, apesar de cada tipo estar associado a uma certa forma de dominação. Cada tipo de técnica implica modos de formação e de transformação dos indivíduos, na medida em que se trata de adquirir certas aptidões e atitudes. A análise que desempenha um papel central, em seu pensamento tardio, é a da interação operada entre si mesmo e os outros bem como a das técnicas de dominação individual, isto é, o modo de ação que um indivíduo exerce sobre si mesmo através das técnicas de si.

Neste centro encontra-se a articulação entre as técnicas do poder e as técnicas de si. Pode-se considerar a noção de governamentalidade um dos principais conceitos operatórios para tal genealogia. A governamentalidade é o conjunto de técnicas e procedimentos destinados a dirigir a conduta dos homens, permitindo-nos falar de governo - em seu sentido amplo (governo de uma família, uma casa, um principado, um Estado, das almas) - de si mesmo. Enfim, governo de si e dos outros. Governo de si, condição do governo do outro, que o cristianismo reorganizou instituindo uma hermenêutica de si que é uma decifração de si próprio como sujeito de desejo.

O método de tal pesquisa distingue os atos do código moral e substitui uma história dos sistemas de moral, feita a partir das proibições, por uma 
história das problematizações éticas, feita a partir das práticas de si. Aí, os atos, as condutas, são o comportamento efetivo das pessoas diante do código moral que lhes é imposto, de suas prescrições.

Mas não é só isso. Com efeito, uma coisa é uma regra de conduta; outra, a conduta que se pode medir a essa regra. Mas, outra coisa ainda é a maneira pela qual é necessário "conduzir-se" - isto é, a maneira pela qual se deve constituir a si mesmo como sujeito moral, agindo em referência aos elementos prescritivos que constituem o código. (Foucault, 1984a: 27)

Em O Uso dos Prazeres são apontados três componentes da moral: 1) o código moral - conjunto prescritivo de valores e regras de ação propostas ao indivíduo e aos grupos por intermédio de aparelhos prescritivos diversos como família, instituições educativas etc.; 2) a moralidade dos comportamentos comportamento real dos indivíduos em sua relação com as regras e valores propostos; 3) a ética propriamente dita, em que se reúnem as práticas ou técnicas de si.

Foucault se contrapõe, portanto, à tradição das histórias da moral que se engana quando focaliza exclusivamente a história dos códigos do comportamento moral. A seu ver, convém prestar igual atenção à história das formas da subjetivação moral. Este tipo de análise constitui-se de uma busca histórica e filosófica fundada no importante pressuposto de que a ação moral é indissociável das formas de atividade sobre si, que são tão diferentes de uma moral a outra, quanto o sistema de valores, regras e interdições.

Também o elemento forte e dinâmico de uma moral é diferente nas diversas morais. Sua ênfase, afirma Foucault, pode estar do lado do código, de sua capacidade de ajustar-se a todos os casos possíveis, sendo uma moral das instâncias de autoridade (aprendizagem do código, sua observação e sanções). Neste caso, a subjetivação opera-se de forma quase jurídica, com predomínio da lei. Mas há também morais orientadas para a ética, cuja ênfase está do lado das formas de subjetivação e das práticas de si, como é o caso da Antigüidade greco-romana, em que o sistema dos códigos pode ser bem rudimentar. No cristianismo houve justaposições, conflitos e até composições destes tipos de ênfase.

Vejamos o argumento em Uso dos Prazeres. Quatro aspectos que compõem a ética na moral antiga e na cristã são distinguidos. O primeiro é a ontologia ou determinação da substância ética, isto é, o modo pelo qual o indivíduo deve considerar uma determinada parte de si como sendo o material prin- 
cipal sobre o qual se vai pautar sua conduta moral. Na moral grega clássica, do ponto de vista da sexualidade, trata-se da aphrodisia, a saber, ato, prazer e desejo; na moral cristã, trata-se da 'carne' definida a partir da finitude, da queda e do mal.

O segundo aspecto é a deontologia, isto é, o modo de sujeição, aquele pelo qual o indivíduo estabelece sua relação com a regra e se reconhece como ligado à obrigação de colocá-la em prática. Trata-se, na moral grega, das condições e das modalidades de seu uso, enquanto na moral cristã, da lei e da obediência.

O terceiro aspecto é a ascética, isto é, as formas do trabalho ético, da experiência ética, que o indivíduo efetua sobre si mesmo, não somente para tornar seu comportamento conforme a uma regra dada, mas, sobretudo, para tentar transformar a si mesmo em sujeito moral de sua conduta. Tratase, na moral grega, da forma ativa de mestria de si, enquanto na cristã, da decifração da alma e da hermenêutica dos desejos, subordinadas à obediência incondicional à figura do pastor.

Finalmente, uma teleologia do sujeito moral, sua finalidade, que é a constituição de uma conduta moral que leva o indivíduo a um certo modo de ser, característico do sujeito moral. Na moral grega constitui-se da busca da liberdade ativa indissociável de uma relação com a verdade, enquanto na cristã, da busca da pureza que tende à renúncia a si.

Isto significa, para Foucault, que uma ação para ser chamada moral não pode ser reduzida a um ato ou série de atos conformes a uma regra, lei ou valor. Pois, envolve uma certa relação a si - que não é simplesmente consciência de si, mas sobretudo, constituição de si como experiência, como sujeito moral, na qual o indivíduo circunscreve a parte dele mesmo que constitui o objeto de sua prática moral, define sua posição em relação ao preceito que respeita, estabelece para si um certo modo de ser que valerá como realização moral dele mesmo. Para tanto, age sobre si mesmo, procura conhecer-se, aperfeiçoa-se, transforma-se.

Não existe ação moral particular que não se refira à unidade de uma conduta moral; nem conduta moral que não implique a constituição de si mesmo como sujeito moral; nem tampouco constituição do sujeito moral sem 'modos de subjetivação', sem uma 'ascética' ou sem 'práticas de si' que as apóiem. (Foucault, 1984a: 29)

Em O Cuidado de Si, Foucault estuda o que ele denomina cultura de si, apontando, no pensamento filosófico e médico dos primeiros séculos de nos- 
sa era, uma inquietude e uma severidade crescentes a respeito dos prazeres, inclusive os sexuais, que de alguma maneira independem do poder público, da lei ou dos costumes propriamente. Antes, dizem respeito a uma iniciativa de certos indivíduos e grupos que intensificaram e valorizaram as relações consigo mesmos através de uma filosofia fundada, desde o helenismo, nos preceitos da ascese e do "cuidar-se".

Estes preceitos envolvem inúmeras atividades, tarefas práticas, exercícios, muitos cuidados consigo mesmo, numa correlação estreita entre a prática e o pensamento filosóficos, médicos e morais. Por exemplo: exame de consciência, cuidados do corpo, regimes de saúde, exercícios físicos sem excesso, satisfação tão comedida quanto possível, meditações, leituras, anotações de conversas ou de livros a serem relidas em seguida, rememoração das verdades conhecidas para delas melhor apropriar-se, conversas com um confidente, correspondência em que se expõe o estado de alma, solicitação de conselhos. Trata-se, portanto, de todo um conjunto de atividades da palavra oral e da escrita em que se ligam o trabalho de si sobre si e a comunicação com outro (Foucault, 1984a) - práticas ao mesmo tempo individuais e sociais.

Nestas práticas, o conhecimento ocupa, sem dúvida, um lugar considerável. Entretanto, para Foucault, sua finalidade não é a renúncia de si, como no pensamento do cristianismo, mas a aquisição de uma virtude que permitiria a constituição de uma soberania de si, de uma forma de medida e da confirmação da independência quanto a tudo aquilo que não é indispensável nem essencial. Nestes trabalhos sobre si inclui-se aquele do pensamento sobre si mesmo. Seu papel é operar uma filtragem permanente das representações, seguindo o princípio daquilo que depende ou não de nós, em que se desvaloriza o que não depende de nós, para a conversão a si e a posse de si.

Esta questão é elaborada por Foucault através de uma pretensão, por um lado, de definir a filosofia como estilo de vida e não como posse da habilidade argumentativa com vistas à descoberta da verdade; por outro, de rediscutir a noção de ética, desvinculando-a dos tradicionais problemas morais.

Em O Cuidado de Si, é no quadro dos temas e das práticas de uma cultura de si, que se desenvolveram, nos séculos I e II, era de ouro do cuidado de si, reflexões sobre a moral dos prazeres e sua austeridade, não como resposta a interdições mais duras, nem como tentativas de barrar o desejo, mas em busca de certas modificações no âmbito da constituição da subjetividade moral. Nessa época, a moral sexual ainda exige que o indivíduo se sujeite a uma certa arte de viver que define os critérios estéticos e éticos da existência como no 
helenismo; só que essa arte, na idade do ouro da cultura de si, refere-se, cada vez mais, a princípios universais da natureza ou da razão.

A definição do trabalho a ser realizado sobre si mesmo sofre, então, uma mudança que coloca a questão da verdade no centro da constituição do sujeito moral, apesar de ainda ter, como ponto máximo de sua elaboração, a soberania do indivíduo sobre si mesmo. Porém, esta soberania amplia-se numa experiência em que a relação a si ganha a forma não apenas de uma dominação, mas de um prazer consigo, isento de desejo e de perturbação.

Apesar dos cuidados e temores que a experiência dos prazeres sexuais inspira, ainda há uma distância entre esta experiência e sua associação ao mal, ao comportamento submetido à forma universal da lei, à decifração do desejo como condição indispensável para uma existência purificada como acontecerá no ascetismo cristão. Já aparecem, contudo, a questão do mal ligado ao antigo tema da força, a questão da lei fazendo uma inflexão no tema da arte e da técnica e a questão da verdade e o princípio do conhecimento de si ligando-se às práticas da ascese.

Neste contexto, coloca-se a hipótese foucaultiana que o preceito délfico do "conhece-te a ti mesmo" teria aparecido na filosofia ligado a Sócrates, subordinado ao quadro mais geral do preceito do cuidado de si, sendo uma de suas formas, uma de suas aplicações concretas e particulares; que o cuidado de si teria percorrido, com diferentes modalidades, todo o decurso da filosofia antiga, tendo seu apogeu nos séculos I e II de nossa era; teria sido reencontrado no cristianismo tornando-se uma espécie de matriz do ascetismo cristão.

Definido como conjunto de experiências modificadoras do sujeito para ter acesso à verdade com a finalidade de transformar o ser mesmo do sujeito, o cuidado de si é privilegiado por Foucault como ponto de partida e fundamento da moral na Antigüidade, em contraposição ao privilégio concedido pelos historiadores e antropólogos ao preceito délfico.

Para Foucault, o cuidado de si teria perdido a importância com a introdução, na filosofia moderna, do princípio da evidência da consciência. Tal princípio interroga as condições e os limites do acesso do sujeito ao conhecimento, situando-as no próprio conhecimento, através de uma analítica da verdade. As técnicas de si ou artes da existência perderam grande parte de sua importância e de sua autonomia não somente quando se impõe o princípio da evidência do sujeito e da verdade na consciência, que Foucault chama de momento cartesiano. Isto começa a ocorrer com o cristianismo quando foram 
estas técnicas foram integradas no exercício de um poder pastoral (Foucault, $2003)^{84}$ e, mais tarde, nas práticas modernas de tipo educativo, médico ou psicológico. Embora tenha perdido para nós sua força, a genealogia mostra que o cuidado de si constitui, na Antigüidade, um dos grandes princípios das cidades, uma das regras de conduta da vida social e individual, um trabalho sobre a própria vida.

${ }^{84}$ Foucault concebe o poder pastoral como o modo de governar os indivíduos, de ordem religiosa, dirigindo-os nos mínimos detalhes da vida, através do conhecimento exaustivo de sua interioridade, produzindo uma verdade subjetiva pelo ascetismo cristão baseado na confissão, no exame e direção de consciência. Predominou, no Ocidente, até a segunda metade do século XVIII. A partir de então, prevalece o modo de governar voltado para o Estado, fundado na Razão de Estado e de práticas de gestão cujo alvo é a vida dos indivíduos e das populações, através de novos saberes (economia, estatística, medicina etc.) e novas práticas (reabilitação das práticas disciplinares, as práticas de medicalização e normalização, as práticas da biopolítica e seus dispositivos de segurança) cujos mecanismos principais são os dispositivos de segurança. 


\section{2 \\ Governamentalidade e Cuidado de Si}

\section{A QUESTÃO DO SUJEITO ATIVO}

$E_{m}$ seu pensamento tardio, Foucault volta-se para o problema da relação do sujeito consigo mesmo, com os outros e com a verdade, a partir da concepção de vida como obra de arte. Tal concepção é estudada por meio de uma genealogia do homem do desejo, que ele tenta empreender, ainda que de uma perspectiva diferente, desde a História da Sexualidade 1. Situa-se numa perspectiva ética que se interpõe a uma estética da existência. Nesta genealogia, são pesquisados os modos de problematizar a autoformação do sujeito e sua permanente autotransformação nas escolas da Antigüidade greco-romana, a partir da noção de poder como campo estratégico de relações móveis e transformáveis, domínio analisado como o da governamentalidade. Domínio que não se delimita mais, no pensamento foucaultino, pela preocupação com a questão da gestão governamental do Estado, ${ }^{85}$ mas pelo problema do governo de si e dos outros, do cuidado de si e dos outros e suas tecnologias.

O que está em foco, então, é a investigação de uma relação do sujeito consigo mesmo que não se reduz à consciência de si ${ }^{86}$ mas se centraliza na idéia de constituição de si mesmo como experiência, como sujeito moral ativo,

\footnotetext{
${ }^{85}$ A partir do momento em que Foucault cunha a noção de biopoder e tematiza diretamente a questão do Estado, a governamentalidade torna-se um conceito operatório para suas pesquisas sobre a gênese do Estado, realizada com base no estudo das práticas de gestão governamental, que objetivam a vida da população, para a qual a economia é o saber mais importante, e os dispositivos de segurança seus principais mecanismos (Foucault, 2008).

${ }^{86}$ Como ocorreria no caso do modo de governo caracterizado por Foucault como poder pastoral. Ver a esse respeito a última nota do Apêndice 1. Conferir, ainda, "Omnes et singulatim" (Foucault, 1994d).
} 
como no pensamento helenista. Nesta experiência, o elemento preponderante é a possibilidade de o próprio indivíduo: a) circunscrever a parte de si mesmo que constitui o objeto de sua prática moral, b) definir sua posição em relação ao preceito que respeita, c) estabelecer para si mesmo um modo de ser que deverá ter o valor moral de realização de si mesmo. Para tanto, ele age sobre si mesmo, procura conhecer-se, aperfeiçoa-se, transforma-se.

Na Antigüidade, tal constituição de si mesmo é um processo que envolve inúmeras atividades. Sua realização se dá numa correlação estreita entre a prática e o pensamento pedagógicos, filosóficos, médicos e morais. Nestas práticas de constituição de si mesmo, ressalta-se a necessidade do conhecimento de si, que ocupa, sem dúvida, um lugar considerável. Entretanto, ao estudá-las, Foucault ressalta a importância de enfocar a finalidade destas atividades não como renúncia a si mesmo, como no cristianismo, em nome de um deus e de outra vida. Ao contrário da renúncia a si buscada pelo pensamento cristão, no helenismo, busca-se uma virtude que conduza à afirmação de si mesmo; pois o que se busca é da ordem da formação de uma soberania do sujeito, do estabelecimento de uma forma de medida e da confirmação da independência do indivíduo com relação a tudo aquilo que não se mostre indispensável nem essencial para a vida do sujeito. $O$ trabalho do pensamento sobre si mesmo é uma das formas destas práticas. De acordo com as escolas helenísticas, seu papel é operar uma filtragem permanente das representações, seguindo o princípio daquilo que depende ou não de nós, em que se desvaloriza o que não depende de nós, para a conversão e a posse de si mesmo.

Esta questão é elaborada por Foucault com base numa pretensão não só de definir a filosofia como estilo de vida, e não, exclusivamente, como posse da habilidade argumentativa com vistas à descoberta da verdade; mas também de rediscutir a noção de ética, desvinculando-a dos tradicionais problemas morais. Em sua genealogia do homem do desejo, tal pretensão conduz a questão ética da relação entre sujeito e verdade por meio de uma pesquisa da gênese do trabalho a ser realizado pelo sujeito sobre si mesmo. No pensamento helenístico, tal trabalho se define ao mesmo tempo que coloca a verdade no centro do problema da constituição do sujeito, apesar de a soberania do indivíduo ser considerada por Foucault o ponto máximo de sua elaboração. $O$ cerne do interesse da genealogia parece, então, ser esta soberania ampliada numa experiência na qual a relação a si ganha a forma não apenas de uma dominação, mas de um prazer consigo mesmo, sereno, isento de desejo e de perturbação. 
Minha hipótese é que há, pelo menos, duas questões relevantes do pensamento tardio de Foucault que permitem traçar um quadro de inteligibilidade esclarecedor a respeito da formação de um sujeito ativo. Primeiro, a questão das relações de forças e do governo, governo de si e governo dos outros; segundo, a atualidade da investigação foucaultiana ao traçar um recuo genealógico até as práticas e o pensamento das escolas helenísticas - dos epicuristas, dos cínicos, dos estóicos - pelo viés das técnicas de si.

\section{RELAÇÕES DE FORÇAS E GOVERNO}

Desde que não consideremos, com Foucault, que haja um sujeito previamente dado, a priori, universal, essencial - o que quer dizer que estaríamos representando um 'sujeito-fundamento' tanto do ponto de vista da ética quanto do conhecimento - na busca de decifrar 'o que somos nós', 'qual é nossa essência'; mas que consideremos que o sujeito seja uma construção histórica, uma possibilidade, uma forma de problematizar o indivíduo, isto é, de lidar com aquilo que chamamos de subjetividade; então, em seu estudo das práticas e do pensamento helenísticos, importa a lição de que é preciso investigar as diferentes formas de relação do sujeito consigo mesmo, pesquisar as técnicas de si que podem ser encontradas, em todas as culturas, de modos diferentes.

Para Foucault, devemos questionar as técnicas de si, através das quais o sujeito se constitui, exatamente do mesmo modo como é necessário estudar e comparar as diferentes técnicas de produção de objetos e de direção dos homens pelos homens através do governo. O problema, ele afirma, é que a análise de si é muito difícil. Em primeiro lugar, porque as técnicas de si não exigem o mesmo aparato material que a produção de objetos, sendo, inclusive, técnicas sobre objetos muitas vezes invisíveis. Em segundo lugar, são freqüentemente ligadas às técnicas de direção dos outros. Por exemplo, no caso das instituições educacionais, chama a atenção o fato de, sempre, alguém estar governando outros e ensinando-lhes a governar-se.

A partir do final do século XX, chama a atenção a crescente valorização da luta contra as formas de sujeição, ou melhor, contra a submissão da subjetividade. Ela ganha cada vez mais destaque em relação às lutas contra as formas de dominação e exploração econômica e social, que sobressaíram, no Ocidente, no século XX e, é claro, se mantêm. O problema da submissão da subjetividade se coloca, no pensamento de Foucault, através de sua suspeita de que o mais evidente dos problemas filosóficos é a questão do tempo presente e 
daquilo em que estamos nos transformando neste exato momento. A suspeita de que, hoje em dia, é preciso recusar o que somos e, talvez, não mais buscar descobrir o que somos.

Daí a injunção foucaultiana de imaginar e construir o que poderíamos estar nos tornando, livrando-nos do duplo constrangimento político da modernidade ocidental, que é a simultaneidade dos processos de individualização e de totalização, próprios das estruturas do poder moderno. Trata-se de pensar formas de exercício de poder afastadas da determinação do sujeito objetivado pelos saberes e pelos poderes modernos institucionalizados, tais como o saber das ciências biomédicas e do homem, o poder disciplinar e o biopoder.

Na modernidade, nossa subjetividade não deixa de apontar para possibilidades de novas invenções. Já que o poder é concebido por Foucault como algo diferente da violência, como sendo constituído necessariamente por forças em relação - relação em que o outro é indispensável e a liberdade intransitiva - é possível pensar a realidade diferentemente do que ela é.

Além de não se definir como violência, uma relação de poder não é um modo de ação que age direta e imediatamente sobre os indivíduos, mas uma "ação sobre a ação, sobre ações eventuais ou atuais, futuras ou presentes". Ao contrário das relações de poder, "uma relação de violência age sobre um corpo, sobre as coisas; ela força, ela submete, ela quebra, destrói; ela fecha todas as possibilidades" (Dreyfus \& Rabinow, 1995: 243). A noção de ação sobre ação é da ordem do governo.

Ao se dirigir ao período helenístico, Foucault busca enfocar a relação do indivíduo consigo mesmo, pensando-a em termos de governo - governo sobre a ação dos outros e governo de si sobre a própria ação. Certamente, poder-se-ia objetar, como ele mesmo lembra ao referir-se a esta abordagem, que todos os tipos de sujeição são fenômenos derivados, meras conseqüências de outros processos econômicos e sociais, tais como forças produtivas, lutas de classes, estruturas ideológicas, todo um Estado determinando a forma da subjetividade.

Contudo, em sua opinião, o maior problema político, ético, social e filosófico de nossos dias não consistiria apenas em tentar liberar os indivíduos do Estado, nem de suas instituições, mas liberá-los tanto do Estado quanto do tipo de individualização que a ele se liga. Seria necessário promover novas formas de subjetividade, recusando este tipo de individualidade que nos foi imposto há vários séculos, por meio das tecnologias disciplinares e de normalização. 
Lembremos que, em Vigiar e Punir, Foucault torna evidente que diversos procedimentos disciplinares já existiam, há muito tempo, nos conventos, nas Forças Armadas, nas escolas, nas oficinas, e que se tornam, a partir do século XVII, fórmulas gerais de dominação. Os modos da repartição disciplinar aparecem, então, correspondendo a saberes e técnicas de classificação e de ordenação em quadros que introduzem o problema específico dos indivíduos e da população. O corpo do indivíduo aparece como provido de condições de funcionamento próprias a um organismo que fazem com que o poder disciplinar se dirija a uma individualidade analítica, celular, individual, natural, a partir de todos os corpos que controla.

Através da disciplina, surge o poder da normalização. Do mesmo modo que a vigilância, a normalização torna-se um dos grandes instrumentos de poder a partir do final da época clássica. Ela substitui ou acrescenta graus de normalidade, que são signos de pertença a um corpo social homogêneo, mas que se divide em classes. A normalização, para Foucault, constrange para homogeneizar as multiplicidades, ao mesmo tempo que individualiza, porque permite as distâncias entre os indivíduos, determina níveis, fixa especialidades e torna úteis as diferenças.

Em Vigiar e Punir e em A Vontade de Saber, apontam-se não só o modo peculiar de funcionamento das normas modernas, mas o mal-estar que causam. Dentre as técnicas e os saberes por ele analisados, a normalização constitui um problema fundamental, visto que todas as sociedades têm normas de socialização dos indivíduos. Mas o perigo de nossas normas é que, a partir da modernidade, elas funcionam de modo muito sutil, com estratégias sem estrategista aparente, impondo uma rede uniforme de normalidade.

$\mathrm{Na}$ constituição desta rede uniforme de normalidade, as relações de poder não devem ser confundidas com as relações de comunicação nem com capacidades objetivas. $\mathrm{O}$ que não significa que se trate de três domínios separados: o domínio das coisas, da técnica finalizada, da capacidade objetiva, do trabalho e da transformação do real; o domínio dos signos, da comunicação, da reciprocidade e da fabricação do sentido, e, finalmente, o domínio da dominação dos meios de coação, de desigualdade e de ação dos homens sobre os homens.

Trata-se, antes, de três tipos de relação sempre imbricados uns nos outros, apoiando-se reciprocamente e servindo-se mutuamente de instrumento. A aplicação da capacidade objetiva, nas suas formas mais elementares, implica relações de comunicação - seja de informação prévia, ou de trabalho dividido -, liga-se 
a relações de poder - seja de tarefas obrigatórias, de gestos impostos por uma tradição ou um aprendizado, de subdivisões ou de repartição mais ou menos obrigatória do trabalho.

As relações de comunicação implicam atividades finalizadas - mesmo que seja apenas a 'correta' operação dos elementos significantes - e induzem efeitos de poder pelo fato de modificarem o campo de informação dos parceiros. Quanto às relações de poder, elas se exercem através da produção e da troca de signos; mas não são dissociáveis das atividades finalizadas, seja daquelas que permitem exercer este poder (como as técnicas de adestramento, os procedimentos de dominação, as maneiras de obter obediência), seja daquelas que recorrem, para se desdobrarem, a relações de poder (como acontece na divisão do trabalho e na hierarquia das tarefas).

Sem dúvida, para Foucault, a coordenação destes três tipos de relação não é uniforme nem constante. Não há, numa sociedade dada, um tipo geral de equilíbrio entre as atividades finalizadas, os sistemas de comunicação e as relações de poder. Há, antes, diversas formas, diversos lugares, diversas circunstâncias ou ocasiões em que estas inter-relações se estabelecem sobre um modelo específico.

Porém, há blocos, que são conjuntos nos quais o ajuste das capacidades, os feixes de comunicação e as relações de poder constituem sistemas regulados e concordes. Por exemplo, numa instituição escolar: sua organização espacial, o regulamento meticuloso que rege sua vida interior, as diferentes atividades aí organizadas, os diversos personagens que nela vivem e se encontram, cada um com uma função, um lugar, um rosto bem definido - tudo isto constitui um bloco de capacidade-comunicação-poder.

A atividade que aí assegura o aprendizado e a aquisição de aptidões ou de tipos de comportamento se desenvolve através de todo um conjunto de comunicações reguladas (lições, questões e respostas, ordens, exortações, signos codificados de obediência, marcas diferenciais do 'valor' de cada um e dos níveis de saber), bem como através de toda uma série de procedimentos de poder (clausura, vigilância, recompensa e punição, hierarquia piramidal).

Portanto, o exercício do poder é muito complexo e não se constitui simplesmente numa relação entre parceiros individuais ou coletivos. Sua genealogia mostra que há muito mais em jogo. Como se trata de um modo de ação de alguns sobre a ação dos outros, pertence à dimensão da conduta: conduzir os outros, conduzir condutas e ordenar probabilidades, governar. De acordo com Foucault, as relações de poder são da ordem do governo no 
sentido restrito da palavra e foram progressivamente governamentalizadas, ou seja, elaboradas, racionalizadas e centralizadas na forma das instituições do Estado ou sob sua caução.

Mas não é somente no sentido restrito que as relações de poder foram governamentalizadas. Também o foram em seu sentido mais amplo. Em A Hermenêutica do Sujeito (2004), Foucault remete o poder político à governamentalidade. Aí, ela é definida como um campo estratégico de relações de poder não mais restrito a seu âmbito político. Ela é entendida, assim, em seu caráter cambiante de relações estratégicas de forças móveis, transformáveis e reversíveis. Nesta perspectiva, as relações de poder passam, teórica e praticamente, não por um sujeito de direito, um sujeito-identidade, mas por um sujeito definido pela relação de si para consigo mesmo.

Em nossa tradição, as teorias do poder político como instituição ligam-se a uma concepção jurídica do sujeito de direito, sem dúvida, importante para a genealogia foucaultiana. Mas o principal interesse de seu projeto repousa numa concepção de poder a ser analisada em termos de seu potencial de reversibilidade, que a remete a uma ética do sujeito ativo, definido pela relação do sujeito consigo mesmo. O importante nesta proposta é o tipo de análise que se funda na idéia de que é preciso "considerar que relações de poder/governamentalidade/governo de si e dos outros/relação de si para consigo compõem uma cadeia, uma trama e que é em torno destas noções que se pode articular a questão da política e a questão da ética" (Foucault, 2004: 306-7).

Com a hipótese desta trama, explicitada em seu pensamento tardio, Foucault busca estudar um campo de historicidade no qual o indivíduo é chamado a se reconhecer como sujeito moral da conduta sexual. Sua análise é, então, dirigida à maneira pela qual certa forma de subjetivação se estabeleceu e se transformou, a partir da relação do sujeito consigo mesmo, desde o pensamento grego clássico até a constituição da doutrina e da pastoral cristã da carne.

Com estas análises, buscam-se formas de resistência a um tipo de subjetividade que, desde o começo da modernidade, aparece como uma produção dos saberes e do poderes que se exercem em nossa sociedade, escapando de seus pontos mais vivos que são as instituições. Busca-se, ainda, rejeitar a afirmação de um sujeito universal, na tentativa de encontrar um modo de o pensamento escapar de si mesmo Esta atitude consiste na capacidade e na coragem de elaborar sua própria subjetividade, afastada da verdade do sujeito-identidade bem como do poder normalizador da lei e das ciências do homem hegemônico nas sociedades ocidentais. 
Em A Hermenêutica do Sujeito, Foucault explicita a relevância histórica e a singularidade, na cultura ocidental, da 'figura prescritiva' do retorno a si como forma de resistência a ser privilegiada. Ao analisar o papel de uma ética do eu, ele considera que talvez haja uma dificuldade, ou uma impossibilidade para seu estabelecimento. Contudo, esta talvez seja "uma tarefa urgente, fundamental, politicamente indispensável, se for verdade que, afinal, não há outro ponto, primeiro e último, de resistência ao poder político senão na relação de si para consigo" (Foucault, 2004: 306).

\section{Cuidado de si e CONHecimento DE SI}

Esta proposta de resistência ao poder político através da relação do sujeito consigo mesmo converge para o tema da conversão e do retorno a si. Podemos dizer, com Foucault, que o tema do retorno a si, a partir do século XVI, é um tema recorrente na cultura ocidental. No entanto, "este tema, no fundo, foi reconstituído - por fragmentos, por migalhas - em sucessivas tentativas que jamais se organizaram de modo tão global e contínuo como na Antigüidade helenística e romana" (Foucault, 2004: 305). Mesmo no século XVI, aparece diretamente referido aos autores gregos e latinos.

O retorno a si remete ao tema da conversão. Inspirado em Pierre Hadot (2002), Foucault apresenta esquematicamente três modelos básicos de conversão: o platônico, o helenístico romano (quando o cuidado de si torna-se uma arte autônoma, que valoriza a existência inteira do sujeito durante todo o decorrer da vida) e o modelo cristão.

No modelo platônico, exemplificado por Alcebíades (Platão, 1975), a relação entre o cuidado de si e conhecimento de si passa pelo reconhecimento da ignorância de Alcibíades, que para governar os outros precisa cuidar-se; toda a superfície de seu cuidado deve ser ocupada pelo imperativo do conhecimento de si que se volta para a própria alma. A reminiscência é o ponto de junção destes elementos. É o modelo da lembrança do próprio ser anteriormente contemplado. Neste modelo, promove-se a transformação do ser mesmo do sujeito, para que ele tenha acesso à verdade e alcance o bom governo da cidade e dos outros; para tanto, precisa governar-se. É preciso cuidar-se para cuidar dos outros.

Ao lado do platonismo, a partir dos séculos III-IV da era cristã, forma-se o modelo cristão de conversão, em que o cuidado de si consiste num retorno a si e num conhecimento de si que, paradoxalmente, é renúncia a si em nome 
de uma vida depois da morte, em nome de Deus. O conhecimento da verdade é obtido pela decifração do Texto divino, pela Revelação e pela exegese de si, que permite detectar a natureza e a origem dos movimentos interiores que se produzem na alma. Correlativamente a este modelo, encontramos o governo das ovelhas pelo pastor.

O terceiro modelo, apresentado por Foucault em A Hermenêutica do Sujeito, foi praticado no final da era antiga e início da nossa era. Em sua opinião, este modelo foi recoberto, posteriormente, pelo prolongamento do modelo da conversão platônica e pelo da conversão cristã. Nele, cuidado de si e conhecimento de si não se identificam, tampouco um é absorvido pelo outro. É o que Foucault chama de autofinalização do cuidado de si. Com suas práticas austeras, há, neste período, uma autonomização da relação a si, do governo de si, que vai se constituir como uma arte da vida que é uma arte de si, modificada e repatriada pelo ascetismo cristão.

Pierre Hadot, a quem Foucault agradece em seus últimos trabalhos, volta-se para o estudo da conversão em suas diferentes modalidades históricas no contexto de uma análise da questão da autoformação do sujeito na Antigüidade. É relevante, aqui, não apenas sua observação sobre as técnicas de conversão a si, mas sua idéia de exercícios espirituais para a autoformação e autotransformação do sujeito, que Foucault denomina de técnicas de si e de vida. Hadot a desenvolve particularmente em Exercices Spirituels et Philosophie Antique (2002).

Segundo Hadot, a expressão 'exercícios espirituais' desconcerta um pouco o leitor contemporâneo. Mas é necessário resignar-se com o emprego do termo, porque os outros qualificativos possíveis, como psíquico, moral, ético, intelectual, de pensamento, da alma, não recobrem todos os aspectos da realidade que ele pretende. De fato, estes exercícios correspondem a uma transformação da visão do mundo e a uma metamorfose da personalidade que a palavra espiritual, a seu ver, permite compreender. Isto porque estes exercícios são um trabalho não apenas do pensamento, mas de todo o psiquismo do indivíduo e, sobretudo, de sua dimensão de elevação à vida do Espírito Objetivo, na perspectiva do Todo. Dos exercícios espirituais da Antigüidade, Hadot ressalta aqueles cujo objetivo é aprender a viver, a dialogar, a morrer e a ler.

É nas escolas helênicas e romanas de filosofia que eles aparecem de forma mais clara; para os estóicos, por exemplo, a filosofia é um conjunto de exercícios que não se restringe ao ensino de uma teoria abstrata nem à exegese de textos. Trata-se de "exercitar-se a viver, quer dizer, consciente e livremente" (Hadot, 
2002: 33); ultrapassando os limites da individualidade para se reconhecer como parte de um cosmos animado pela razão; renunciando ao desejo daquilo que não depende de nós e que nos escapa, para ligar-se apenas àquilo que depende de nós, constituindo uma ação conforme à razão.

O ato filosófico, então, não se situa apenas na ordem do conhecimento, mas na ordem do si e do ser. Corresponde a um progresso que nos torna melhores: é uma conversão que transforma toda a vida, mudando o ser daquele que a alcança. Ela permitiria passar de um estilo de vida obscurecido pelo inconsciente e marcado pela preocupação a um estado de vida autêntico, no qual o homem atingiria a consciência de si, a visão exata do mundo, a paz e a liberdade interiores.

Apesar de suas diferenças, para todas as escolas filosóficas, a principal causa de sofrimento, desordem e inconsciência do homem são as paixões, explica Hadot. Neste sentido, a filosofia será primeiramente, uma terapêutica das paixões; cada escola tem seu método terapêutico próprio, mas todas o ligam a uma transformação profunda da maneira de ver e de ser do indivíduo. $\mathrm{O}$ papel dos exercícios é justamente operar pouco a pouco uma transformação interior, difícil de ser alcançada.

Os exercícios espirituais são diversos: pesquisa, exame aprofundado, leitura, audição, atenção, mestria de si, indiferença às coisas indiferentes, meditação, retórica, memorização. A atenção, por exemplo, é a atitude espiritual fundamental do estóico: vigilância, tensão do espírito, que exige uma concentração no momento presente, uma vez que a paixão é sempre provocada pelo peso do passado ou pelo medo do futuro, que não dependem de nós. Exercício, então, de voltar-se para o minúsculo momento presente, sempre passível de ser dominado, em sua exigüidade, que abre nossa consciência à consciência cósmica, ampliando-a e fazendo-nos conferir um valor infinito ao instante, a cada instante.

A meditação busca a mestria do discurso interior através do diálogo consigo mesmo e com o outro, a mestria da escritura, a da ordenação dos pensamentos e a da transformação da representação do mundo e do comportamento exterior. Por intermédio da meditação, busca-se a representação prévia das dificuldades da vida, como a pobreza, o sofrimento e a morte, que não dependem de nós, mas fazem parte do curso da Natureza. Chega-se a uma transformação total da representação do mundo, do seu próprio clima interior e do seu próprio comportamento exterior, através de três procedimentos: o exercício do discurso interior que diferencia aquilo que depende de nós - a 
liberdade - daquilo que não depende de nós - a Natureza; o diálogo consigo mesmo e com o outro; a escritura. Trata-se de um profundo conhecimento do poder terapêutico atribuído à palavra.

A análise desta questão constitui temática atual e original, tendo em vista a forma inovadora com que é concebida a relação do sujeito com a verdade e a liberdade, bem como a originalidade por ela traçada a partir de seu afastamento em relação às modalidades convencionais de pensamento da filosofia ocidental.

Esta questão é elaborada com base numa pretensão de definir a filosofia, ora como estilo de vida e não apenas como posse da habilidade argumentativa com vistas à descoberta da verdade - como em Foucault e Hadot, por exemplo; ora como artes de vida essencialmente fundadas nas práticas da argumentação com vistas ao uso da verdade numa terapêutica da vida e do desejo - Nussbaum (1994), por exemplo. Em ambos os casos se discute a ética, desvinculando-a dos tradicionais problemas morais.

A preocupação com o cuidado de si, hoje, é crescente; difunde-se e pulveriza-se em diversos campos de práticas e de pensamento, como o campo da educação, da saúde, das ciências. Como afirma Touraine (2000), hoje, o cuidado de si é um valor que está em toda parte. O sujeito é sua versão positiva; a versão negativa é a subordinação dos atores a um sistema de poder que quebra as estruturas sociais para deixar o indivíduo flexível ou submetê-lo a uma ideologia.

As referências a grandes valores desapareceram e foram substituídas por um individualismo da autenticidade ou da abertura para os outros - responsabilidade pessoal ou coletiva. Isto começa nas condutas mais próximas: o cuidado do corpo, da estética, de si. Daí a busca da relação do sujeito consigo, a estima de si supõe o olhar do sujeito sobre si mesmo. $O$ tema da conversão, no sentido da relação de si a si e da construção do sujeito por si mesmo está presente em toda parte. No meu entender, é um importante debate ainda em aberto.

A preocupação com o cuidado de si atravessa cada vez mais o pensamento contemporâneo filosófico e ético, com novas elaborações sobre os conceitos de liberdade, moral, subjetividade, individualismo, verdade, prazer, desejo, entre outros, conferindo-lhes relevância renovada para a constituição de estratégias tanto de crítica à sociedade contemporânea quanto de reflexões sobre as questões daí decorrentes.

A análise das diversas formas ético-filosóficas de elaborar a questão do cuidado de si liga, atualmente, a concepção de sujeito ético ativo às de verda- 
de e de liberdade, enfocando o problema da autoformação e da permanente autotransformação do indivíduo. Este problema torna-se visível na busca de noções como: tecnologias ou técnicas de si, cultura de si, estética da existência (Foucault); exercícios espirituais (Hadot); artes de vida (Nussbaum).

Há diferenças entre estas noções, não só porque são cunhadas com diferentes objetivos e metodologias, mas, também, porque correspondem a diferentes modos de conceber o que é fazer filosofia e como usar este fazer. Entretanto, há, sem dúvida, nesta pluralidade, noções, conceitos e categorias que permitem reuni-las sob uma mesma designação - o cuidado de si. A noção de cuidado de si faz com que todas estas concepções tangenciem-se em formas contemporâneas de problematização da relação do sujeito com a verdade, que são formas irredutiveis ao âmbito das teorias do conhecimento e da argumentação.

Os elementos a partir dos quais é possível compor um quadro do cuidado de si são: primeiro, a ênfase na pesquisa filosófica da historicidade do pensamento em sua relação com a preocupação com as questões "o que é pensar, hoje?", “o que é a atualidade?", elaboradas em termos de atitude de vida e de constituição de um sujeito ético ativo. Segundo, a inspiração, por parte dos filósofos contemporâneos citados, no pensamento ético-filosófico da Antigüidade clássica, compreendido entre o século V a. C. e os dois primeiros séculos da era cristã - inspiração voltada para reflexões alicerçadas em certas formas de história do pensamento, estabelecendo uma reabilitação deste pensamento. Terceiro, a presença recorrente, nestas pesquisas, das noções gregas de techné toû biou ou biou techné (artes da vida, tecnologias de vida), epimeleia heautô̂ (cuidado de si), gnôti seautón (conhece-te a ti mesmo), áskesis (ascese), terapeuiein (terapêutica), parrhesía (parrésia). Em quarto lugar, a relevância atribuída à analogia clássica entre o pensamento filosófico e o médico, a saber, ao caráter terapêutico da filosofia greco-romana, explicitado por Hadot, Foucault e Nussbaum - analogia que não se dá apenas pelo uso do discurso médico, suas metáforas e suas noções centrais pela filosofia, mas também pela própria idéia de que a filosofia é ela mesma terapêutica.

Como ressalta Martha Nussbaum, em The Therapy of Desire: theory and practice in hellenistic ethics (1994), até recentemente, a filosofia fez menos uso da ética do helenismo do que deveria. Contudo, em sua opinião, hoje, deve-se muito aos estóicos, epicuristas e céticos, até mesmo mais do que a Aristóteles e Platão. Ela o afirma a partir de sua hipótese que ignorar as concepções filosóficas que atrelam lógica e emoção, como as do período helenístico, não 
é apenas ignorar o melhor material da tradição ocidental, mas é desconhecer sua influência no desenvolvimento posterior da filosofia.

Ela cita dívidas a esta tradição não só por parte dos vários tipos de pensamento cristão, como por parte dos pensadores modernos como Descartes, Espinoza, Kant, Adam Smith, Hume, Nietzsche, Marx. São exemplos por ela fornecidos: o tema da cólera divina e do perdão dos cristãos como resultante do estoicismo romano; a correspondência entre Descartes e Elizabeth sobre as paixões, devedora de Sêneca; a dívida de Espinoza à teoria estóica das paixões; a teoria moral dos sentimentos de Smith que se funda no modelo estóico; a noção de piedade em Rousseau que se deve ao debate entre os estóicos e Aristóteles; a piedade em Kant baseada no estoicismo; a piedade em Nietzsche e sua dívida a Epíteto e Sêneca.

A seu ver, a negligência quanto à importância do pensamento clássico começa a ser reparada. A partir do final do século XX, alguns acadêmicos importantes vêm trabalhando nesta linha. A principal referência fornecida por Nussbaum é o pensamento tardio de Foucault. O maior valor por ela atribuído a Foucault é ter mostrado algo fundamental a respeito desta tradição helenística, quando salienta até que ponto os mestres não estão somente dando aulas, em suas escolas, mas estão, sobretudo, se engajando em práticas complexas de autoformação.

Conforme fica demonstrado em A Hermenêutica do Sujeito, na filosofia da Antigüidade, como no diálogo de Sócrates com Alcebíades (Platão, 1975), a noção de cuidado de si e a de conhecimento (de si e do mundo) estavam completamente misturadas com formas de experiência de formação e autotransformação do sujeito. A prova da relação sujeito/verdade se estabelecia através da relação modo de vida/discurso de verdade; o cuidado de si e o preceito socrático do conhece-te a ti mesmo foram separados pelos historiadores da filosofia e pelos filósofos da tradição ocidental que priorizaram o caráter do conhecimento e desvalorizaram as práticas do cuidado de si; que os princípios cartesiano da evidência e da dúvida hiperbólica como fundamento da relação sujeito/verdade acentuam esta prioridade.

Em A Propósito da Genealogia da Ética e em Ética do Cuidado de Si como Prática da Liberdade, Foucault afirma: não é necessário ligar problemas morais e sistemas de saber teórico-científico sobre o eu, o desejo, o inconsciente etc., como fazem os atuais movimentos de liberação, na tentativa de elaboração de uma nova moral. Dentre as invenções culturais da humanidade há um tesouro de procedimentos, técnicas, idéias, mecanismos - esta é a lição da 
Antigüidade greco-romana. Estes não podem ser exatamente reativados, mas ajudam a constituir um tipo de ponto de vista que pode ser muito útil para analisar e transformar o que hoje se passa em torno de nós.

Este tesouro não se restringe à razão, ao conhecimento, a um sistema de representações e argumentos auto-referenciados, mas se liga a uma experiência que é um conjunto de práticas refletidas da liberdade. Práticas que constituem uma estética da existência, cujo alvo é a vida do indivíduo como auto-estilização, a vida como obra de arte.

A reflexão foucaultiana sobre a ética é de fundamental interesse para os problemas da ética filosófica contemporânea, se for compreendida como um recuo histórico, que não consiste numa mitificação da Antigüidade como algo a ser transposto ao presente, mas como forma de questionar as evidências de nosso presente, suas falsas necessidades tanto no nível teórico como no nível das práticas institucionais.

Ao analisar a maneira pela qual é inventado, na Antigüidade grega e romana, um tipo de relação de si com o corpo e com o prazer, Foucault mostra sua irredutibilidade ao modelo cristão da decifração do desejo. Ele tenta analisar a ética como um modo de vida no qual bem e bom não são contraditórios entre si; em que o indivíduo e o outro não se sujeitam a elementos externos como regras transcendentais, princípios formais ou universalidades racionais prévia e definitivamente dadas. Seu objetivo é deslocar as fronteiras das morais vigentes para que o sujeito possa ser levado a se transformar, estilizando sua vida na presença do outro, amigo ou mestre virtuoso.

Para Foucault, o cuidado de si teria perdido sua importância com a introdução, na filosofia moderna, do princípio da evidência da consciência. Tal princípio interroga as condições e os limites do acesso do sujeito ao conhecimento, situando-as no próprio conhecimento, por meio de uma analítica da verdade. As técnicas de si ou artes da existência perderam parte de sua importância e de sua autonomia não somente quando se impõe o princípio da evidência do sujeito e da verdade na consciência. Já, anteriormente com o cristianismo, estas técnicas foram integradas ao exercício de um poder pastoral e, mais tarde, às práticas modernas de tipo educativo, médico ou psicológico.

Ao investigá-lo, Foucault dirige-se à Antigüidade greco-romana, na qual a filosofia liga-se à constituição de formas de subjetividade inteiramente afastadas da normalização de nossa modernidade, aprofundando uma das mais importantes questões da filosofia política contemporânea, que é a relação do indivíduo com as estruturas mais abrangentes de poder das quais faz parte. 
Este pensamento, com suas novas abordagens a respeito de como nos libertarmos a nós mesmos dos constrangimentos da sociedade contemporânea, através de um trabalho de nós mesmos sobre nós mesmos no pensamento, pode ser compreendido, sem dúvida, como uma contribuição para pensar em que consiste a atividade filosófica hoje. 



\section{Referências}

ALQUIÉ, F. La Philosophie de Descartes. Paris: Hatier, 1969.

ALTHUSSER, L. Posfácio. Apresentação de Louis Althusser. In: CANGUILHEM, G. O Normal e o Patológico. 5. ed. Trad. Maria Thereza Redig de Carvalho Barrocas. Rio de Janeiro: Forense Universitária, 2002.

BACHELARD, G. Le Rationalisme Appliqué. Paris: PUF, 1949.

BACHELARD, G. La Formation de l'Esprit Scientifique: contribution à une psychanalyse de la connaissance objective. 14. ed. Paris: Vrin, 1989.

BECK, L. J. The Method of Descartes: a study of the regulae. Oxford: Clerendon Press, 1970.

BENTHAM, J. [1791] Le Panoptique. Précédé de l'oeil du pouvoir - entretien avec Michel Foucault. Postface de Michelle Perrot. Paris: Belfond, 1977.

BEYSSADE, M. Descartes. Paris: PUF, 1972.

BRANCO, C. G. Foucault. In: PECORARO, R. (Org.) Os Filósofos: clássicos da filosofia. v. III. Petrópolis, Rio de Janeiro: Vozes, PUC-Rio, 2009.

CANGUILHEM, G. Note sur la situation faite em France à la philosophie biologique. Revue de Métaphysique et de Morale. 52: 322-332, 1947.

CANGUILHEM, G. La constitution de la physiologie comme science: introduction. In: KAYSER, C. (Org.) Traité de Physiologie. Paris: Flammarion, 1963a. v. 1.

CANGUILHEM, G. The role of analogies and models in biological discovery. In: CROMBIE, A. C. (Ed.) Scientific Change. Londres: Heineman, $1963 \mathrm{~b}$.

CANGUILHEM, G. La Connaissance de la Vie. 2. ed. amp. Paris: Hachette, 1965.

CANGUILHEM, G. Le concept et la vie. Revue Philosophique de Louvain, 64: 193-223, 1966.

CANGUILHEM, G. Mort de l'homme ou épuisement du cogito?. Critique, 242: 599-618, juil. 1967. 
CANGUILHEM, G. Études d'Histoire et de Philosophie des Sciences. Paris: Vrin, 1970a.

CANGUILHEM, G. et al. Análisis de Michel Foucault. Trad. Berta Stolior. Buenos Aires: Tiempo Contemporaneo, $1970 b$.

CANGUILHEM, G. De la science et de la contre-science. In: BACHELARD, S. et al. (Orgs.) Hommage à Jean Hyppolite. Paris: Presses Universitaires de France, 1971.

CANGUILHEM, G. Vie. Encyclopaedia Universalis. Paris: Encyclopaedia Universalis, 1973.

CANGUILHEM, G. La Formation du Concept de Réflexe aux VII et XVIII èmes Siècles. Paris: PUF, 1975.

CANGUILHEM, G. Ideologie et Rationalité dans les Sciences de la Vie. Paris: Vrin, 1977.

CANGUILHEM, G. Sur l'histoire de la folie en tant qu'évenement. Le Débat, 41: 37-40, sept.-nov. 1986.

CANGUILHEM, G. Présentation. Michel Foucault Philosophe: rencontre internationale. Paris: Seuil, 1989.

CANGUILHEM, G. Philosophie d'une éviction: l'objet contre la chose. Revue de Métaphysique et de Morale, 95 (1): 125-129, 1990.

CANGUILHEM, G. Du caractère normatif de la pensée philosophique. In: DELAPORTE. F. (Ed.) A Vital Rationalist: selected writings from Georges Canguilhem. Nova York: Zone Books, 1994a.

CANGUILHEM, G. Abertura: Foucault. In: ROUDINESCO, E. et al. (Orgs.) Leituras da História da Loucura. Trad. Maria Ignes Duque Estrada. Rio de Janeiro: Relume-Dumará, 1994b.

CANGUILHEM, G. O Normal e o Patológico. 5. ed. Trad. Maria Thereza Redig de Carvalho Barrocas. Rio de Janeiro: Forense Universitária, 2002.

CASTRO, E. Vocabulário de Foucault: um percurso pelos seus temas, conceitos e autores. Trad. Ingrid Müller Xavier. Belo Horizonte: Autêntica, 2009.

COMTE, A. Discurso sobre o Espírito Positivo. São Paulo: Abril Cultural, 1978.

DAGOGNET, F. La Situation de Cuvier dans l'histoire de la biologie. Revue d'Histoire des Sciences et de leurs Applications, XXIII, janv.-mars 1970.

DAGOGNET, F. Georges Canguilhem, Philosophe de la Vie. Paris: Institut Synthélabo pour le Progrès de la Connaissance, 1997.

DÉCHAMBRE, A. Animismo. In: Dictionnaire Encyclopédique des Sciences Médicales. Paris: Imprimerie A. Labure, 1889.

DELAPORTE, F. (Ed.) A Vital Rationalist: selected writings from Georges Canguilhem. Nova York: Zone Books, 1994.

DELEUZE, G. La Philosophie Critique de Kant. Paris: PUF, 1963. 
DELEUZE, G. L'homme, une existence douteuse. Nouvel Observateur, 81: 1-6, 1966.

DELEUZE, G. Différence et Répétition. 4. ed. Paris: PUF, 1981.

DELEUZE, G. Foucault. Trad. Claudia Sant'Anna Martins. São Paulo: Brasiliense, 1988.

DELEUZE, G. A Filosofia de Kant. Lisboa: Edições 70, 1994.

DeleuZE, G. \& GUATTARI, F. Mille Plateaux. Paris: Minuit, 1980.

DERRIDA, M. Cogito et histoire de la folie. Revue de Métaphysique et de Morale: 3-4, 1964.

DERRIDA, M. Faire justice à Freud. In: ROUDINESCO, E. et al. (Orgs.) Penser la Folie: essais sur Michel Foucault. Paris: Galilée, 1994.

DESCARTES, R. Regras para a Orientação do Espirito. São Paulo: Martins Fontes, 1999.

DREYFUS, H. Sobre el ordenamiento de las cosas: el ser y el poder en Heidegger y en Foucault. In: CANGUILHEM, G. (Ed.) Michel Foucault, Filósofo. Trad. Alberto Luis Bixio. Barcelona: Gedisa, 1999.

DREYFUS, H. \& RABINOW, P. Uma Trajetória Filosófica: para além do estruturalismo e da hermenêutica. Trad. V. Portocarrero. Rio de Janeiro: Forense Universitária, 1995.

ENTRALGO, L. Historia de la Medicina Moderna y Contemporanea. Barcelona: Editorial Científico Médico, 1954.

ENTRALGO, L. Ciencia, Técnica y Medicina. Madri: Alianza Universidad, 1986. EWALD, F. Les Dieux dans la Cuisine. Paris: Aubier, 1978.

FONSECA, M. A. Normalização e direito. In: BRANCO, G. C. \& PORTOCARRERO, V. (Orgs.) Retratos de Foucault. Rio de Janeiro: NAU, 2000. FOUCAULT, M. Raymond Roussel. Paris: Gallimard, 1963.

FOUCAULT, M. L’Archéologie du Savoir. Paris: Gallimard, 1969.

FOUCAULT, M. L'Ordre du Discours. Paris: Gallimard, 1971.

FOUCAULT, M. Histoire de la Folie à l'Âge Classique. 2. ed. Paris: Gallimard, 1972. FOUCAULT, M. O Nascimento da Clínica. Trad. Roberto Machado. Rio de Janeiro: Forense Universitária, 1977.

FOUCAULT, M. Microfísica do Poder. 3. ed. Rio de Janeiro: Graal, 1982.

FOUCAULT, M. História da Sexualidade 2: o uso dos prazeres. Trad. Maria Theresa da Costa Albuquerque e J. Guilhon de Albuquerque. Rio de Janeiro: Graal, 1984a.

FOUCAULT, M. História da Sexualidade 3: o cuidado de si. Trad. Maria Theresa da Costa Albuquerque e J. Guilhon de Albuquerque. Rio de Janeiro: Graal, 1984b. 
FOUCAULT, M. Vigiar e Punir: nascimento da prisão. Trad. Raquel Ramalhete. Petrópolis: Vozes, 1987.

FOUCAULT, M. Dits et Écrits I. Edição estabelecida sob a direção de Daniel Défert e François Ewald. Paris: Gallimard, 1994a.

FOUCAULT, M. Dits et Écrits II. Edição estabelecida sob a direção de Daniel Défert e François Ewald. Paris: Gallimard, 1994b.

FOUCAULT, M. Dits et Écrits III. Edição estabelecida sob a direção de Daniel Défert e François Ewald. Paris: Gallimard, 1994c.

FOUCAULT, M. Dits et Écrits. IV. Edição estabelecida sob a direção de Daniel Défert e François Ewald. Paris: Gallimard, 1994d.

FOUCAULT, M. O sujeito e o poder. In: DREYFUS, H. \& RABINOW, P. (Orgs.) Michel Foucault, uma Trajetória Filosófica: para além do estruturalismo e da hermenêutica. Trad. Vera Portocarrero. Rio de Janeiro: Forense Universitária, 1995.

FOUCAULT, M. Resumo dos Cursos do Collège de France (1970-1982). Rio de Janeiro: Jorge Zahar, 1997.

FOUCAULT, M. A Verdade e as Formas Jurídicas. Trad. Roberto Machado e Eduardo Jardim Morais. Rio de Janeiro: Nau, 1999.

FOUCAULT, M. A vida: a experiência e a ciência. In: MOTTA, M. B. (Org.) Arqueologia das Ciências e História dos Sistemas de Pensamento: Michel Foucault - Ditos e Escritos II. Rio de Janeiro: Forense Universitária, 2000.

FOUCAULT, M. História da Sexualidade 1: a vontade de saber. Trad. Maria Theresa da Costa Albuquerque e J. Guilhon de Albuquerque. Rio de Janeiro: Graal, 2001a.

FOUCAUlT, M. Fearless Speech. Edited by Joseph Pearson. Los Angeles: Semiotext(e), 2001b.

FOUCAULT, M. As Palavras e as Coisas: uma arqueologia das ciências humanas. Trad. Salma Tannus Muchail. São Paulo: Martins Fontes, 2002a.

FOUCAUlT, M. Em Defesa da Sociedade. Curso no Collège de France (1975-1976). Trad. Maria Ermantina Galvão. São Paulo: Martins Fontes, 2002b.

FOUCAULT, M. Estratégia, Poder-Saber: Michel Foucault - Ditos e Escritos IV. Rio de Janeiro: Forense Universitária, 2003.

FOUCAULT, M. A Hermenêutica do Sujeito. Trad. Márcio Alves da Fonseca e Salma Thanus Muchail. São Paulo: Martins Fontes, 2004.

FOUCAULT, M. Segurança, Território e População. Curso dado no Collège de France (1977-1978). Trad. Eduardo Brandão. São Paulo: Martins Fontes, 2008a.

FOUCAULT, M. Le Gouvernement de Soi et des Autres I: Cours au Collège de France (1983-1984). Paris: Seuil, Gallimard, 2008b.

FOUCAULT, M. Le Courage de la Verité: le gouvernement de soi et des autres II - Cours au Collège de France (1983-1984)]. Paris: Seuil, Gallimard, 2009. 
HADOT, P. Exercices Spirituels et Philosophie Antique. Paris: Albin Michel, 2002.

HAN, B. L'Ontologie Manquée de Michel Foucault: entre l'historique et le transcendental. Grenoble: Jerôme Millon, 1998.

HEIDEGGER, M. Kant et le Problème de la Métaphysique. Paris: Gallimard, 1953. HUSSERL, E. La Crise des Sciences Européennes et la Phénoménologie Transcendentale. Trad. Gérard Granel. Paris: Gallimard, 1976.

JACOB, F. A Lógica da Vida: uma história da hereditariedade. Trad. Ângela Loureiro de Souza. Rio de Janeiro: Graal, 1983.

KANT, E. Antropologie du Point de Vue Pragmatique. Trad. e notas de Michel Foucault. Paris: Vrin, 1964.

KANT, E. Critique de la Faculté de Juger. Paris: Vrin, 1965.

KANT, E. Logique. Paris: Vrin, 1966.

KANT, E. Critique de la Raison Pure. Trad. Tremesaygues e Pacaud. Paris: PUF, 1971.

KANT, E. Princípios Metafísicos da Ciência da Natureza. Trad. Artur Morão. Lisboa: Edições 70, 1990.

KOYRÉ, A. Do Mundo Fechado ao Universo Infinito. Rio de Janeiro: Forense Universitária, 2001.

KUHN, T. A Estrutura das Revoluções Científicas. São Paulo: Perspectiva, 1982.

LALANDE, A. Vocabulaire Technique et Critique de la Philosophie. 13. ed. Paris: PUF, 1980.

LAMARCK, J. B. Philosophie Zoologique. Paris: Dentu, 1809.

LATOUR, B. Give me a laboratory and I will raise the world. In: KNORRCETINA, K. \& MULKEY, K. (Eds.) Science Observed: perspective on the social study of science. Beverly Hills: Sage, 1983.

LATOUR, B. Les Microbes: guerre et paix - suivi de irreductions. Paris: A. M. Métailier, 1984.

LATOUR, B. Science in Action: how to follow scientists and engineers through society. Harvard: Harvard University Press, 1987.

LATOUR, B. Mixing human and non-human together: the sociology of a doorcloser. Social Problems, 35: 298-310, 1988.

LATOUR, B. Nous n'Avons Jamais Eté Modernes: essay d'anthropologie symétrique. Paris: La Découverte, 1991.

LATOUR, B. Michel Serres: éclaircissements - entretiens avec Bruno Latour. Paris: François Bourin, 1992.

LATOUR, B. Les Objets Ont-ils une Histoire? Rencontre de Pasteur et de Whitehead dans le bain d'acide lactique. Paris: Vrin, 1994.

LATOUR, B. Petite Réflexion sur le Culte Moderne des Dieux Faitiches. Paris: Synthélabo, 1996. 
LATOUR, B. L'histoire des sciences a-t-elle un sens? Deux tradictons s'affrontent pour comprendre l'événement scientifique. La Recherche, 303, nov. 1997.

LATOUR, B. A Esperança de Pandora. Bauru: Edusc, 2001.

LATOUR, B. \& WOOLGAR, S. Laboratory Life: the social construction or scientific facts. Beverly Hills: Sage, 1979.

LE BLANC, G. Canguilhem et les Normes. Paris: PUF, 1998.

LEBRUN, G. Transgredir a finitude. In: RIBEIRO, J. (Org.) Recordar Foucault. São Paulo: Brasiliense, 1985.

LEBRUN, G. Nota sobre a fenomenologia contenida en las palabras y las cosas. In: CANGUilHeM, G. (Ed.) Michel Foucault, Filósofo. Trad. Alberto Luis Bixio. Barcelona: Gedisa, 1999.

LITTRÉ, E. Vitalisme. Dictionnaire de Médecine, de Chirurgie, de Pharmacie, de L'Art Vétérinaire et des Sciences qui s'y Rapportent. 14. ed. Paris: Baillière et Fils, 1878.

LÖWY, I. Fleck e a Historiografia recente da pesquisa biomédica. In: PORTOCARRERO, V. (Org.) Filosofia, História e Sociologia das Ciências 1: abordagens contemporâneas. Rio de Janeiro: Editora Fiocruz, 2002.

MACHADO, R. Ciência e Saber: a trajetória da arqueologia de Michel Foucault. Rio de Janeiro: Graal, 1981.

MACHADO, R. Introdução a Michel Foucault. In: FOUCAULT, M. Microfisica do Poder. Organização e tradução de Roberto Machado. 3. ed. Rio de Janeiro: Graal, 1982.

MACHADO, R. Nietzsche e a Verdade. Rio de Janeiro: Rocco, 1984.

MACHADO, R. Deleuze e a Filosofia. Rio de Janeiro: Graal, 1990.

MACHADO, R. Arqueologia, filosofia e literatura. In: BRANCO, C. G. \& PORTOCARRERO, V. (Orgs.) Retratos de Foucault. Rio de Janeiro: NAU, 2000a.

MACHADO, R. Foucault, a Filosofia e a Literatura. Rio de Janeiro: Jorge Zahar, 2000b.

MACHADO, R. Duas filosofias das ciências do homem. In: CALOMENI, T. C. B. (Org.) Michel Foucault: entre o murmúrio e a palavra. Campos, RJ: Faculdade de Direito de Campos, 2004.

MACHADO, R. A Ciência e o Saber. Rio de Janeiro: Zahar, 2006.

MACHEREY, P. Posfácio: a filosofia da ciência de Georges Canguilhem: epistemologia e história das ciências. In: CANGUILHEM, G. O Normal e o Patológico. 5. ed. Trad. Luiz Otávio F. Barreto Leite. Rio de Janeiro: Forense Universitária, 2002.

NIETZSCHE, F. Para além do Bem e do Mal. Trad. Hermann Pflüger. Lisboa: Guimarães, 1978.

NUSSBAUM, M. The Therapy of Desire: theory and practice in hellenistic ethics. Princeton, New Jersey: Princeton University Press, 1994. 
ORTEGA, F. Amizade e Estética da Existência em Foucault. Rio de Janeiro: Graal, 1999.

PASTEUR, L. Oeuures de Pasteur. Edição organizada por P. Valléry-Radot. Paris: Masson et Cie., 1922. 7 t.

PLATÃO. O primeiro Alcebíades. Obras Completas de Platão. Trad. Carlos Alberto Nunes. Belém: Universidade Federal do Pará, 1975.

POL-DROIT, R. Foucault: entrevistas. Trad. Vera Portocarrero e Gilda Gomes Carneiro. São Paulo: Graal, 2006.

POPPER, K. Conhecimento Objetivo. São Paulo: Edusp, 1972.

PORTOCARRERO, V. Pasteur e a microbiologia. Revista da Sociedade Brasileira de História da Ciência, 5: 69-81, jan.-jun., 1991.

PORTOCARRERO, V. Instituição escolar e normalização em Foucault e Canguilhem. Educação $\mathcal{E}$ Realidade, 29(1): 169-185, jan.-jun. 2004.

PORTOCARRERO, V. Foucault: ética e valores. Educação, 3: 46-55, 2007. (Especial: Biblioteca do Professor - Foucault Pensa a Educação).

RABINOW, P. Introduction. In: DELAPORTE, F. (Ed.) A Vital Rationalist: selected writings from Georges Canguilhem. Nova York: Zone Books, 1994.

RADL, E. M. Historia de las Teorias Biológicas. Madri: Alianza Ed., 1988.

RAJCHMAN, J. Foucault: a liberdade da filosofia. Trad. Álvaro Cabral. Rio de Janeiro: Zahar, 1987.

RAJCHMAN, J. Foucault Pragmático. In: BRANCO, C. G. \& PORTOCARRERO, V. (Orgs.) Retratos de Foucault. Rio de Janeiro: NAU, 2000.

SALOMONT-BAYET, C. Le theatre de la preuve. In : SALOMONT-BAYET, C. (Org.). Pasteur et la Révolution Pastorienne. Paris: Payot, 1986.

SERRES, M. Eclaircissements : entretiens avec Bruno Latour. Paris: François Bourin. 1992.

TOLSTOI, L. [1869] La Guerre et la Paix. Paris: Follio, 1960.

TOURAINE, A. Invitation. In: TOURAINE, A. \& KHOSROKHAVAR, F. La Recheche de Soi : dialogue sur le sujet. Paris: Athème Fayard, 2000.

VUILlEMIN, J. Physique et Métaphysique Kantiennes. Paris: PUF, 1955.

VUILLEMIN, J. Mathématiques et Métaphysique chez Descartes. Paris: PUF, 1960. 
Formato: $16 \times 23 \mathrm{~cm}$

Tipologia: Goudy Old Style

Papel: Pólen Bold 70g/m2(miolo)

Cartão supremo $250 \mathrm{~g} / \mathrm{m} 2$ (capa)

CTP, impressão e acabamento: Imprinta Express Gráfica e Editora Ltda.

Rio de Janeiro, outubro de 2009.

Não encontrando nossos títulos em livrarias, contactar:

\section{Editora Fiocruz}

Av. Brasil, 4036 - térreo - sala 112 - Manguinhos

CEP 21040-361 - Rio de Janeiro - RJ.

Tel.: (21) 3882-9039 e 3882-9041 - Telefax: (21) 3882-9006

editora@fiocruz.br | www.fiocruz.br/editora 